ФЕДЕРАЛЬНЫЙ ИССЛЕДОВАТЕЛЬСКИЙ ЦЕНТР

КОЛЬСКИЙ НАЧЧНЫЙ ЦЕНТР

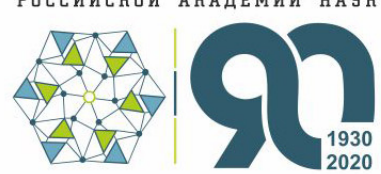

ИНСТИТУТ ЭКОНОМИЧЕСКИХ ПРОБЛЕМ ИМ. Г.П. ЛУЗИНА ФЕДЕРАЛЬНОГО ИССЛЕДОВАТЕЛЬСКОГО ЦЕНТРА «КОЛЬСКИЙ НАУЧНЫЙ ЦЕНТР РОССИЙСКОЙ АКАДЕМИИ НАУК»

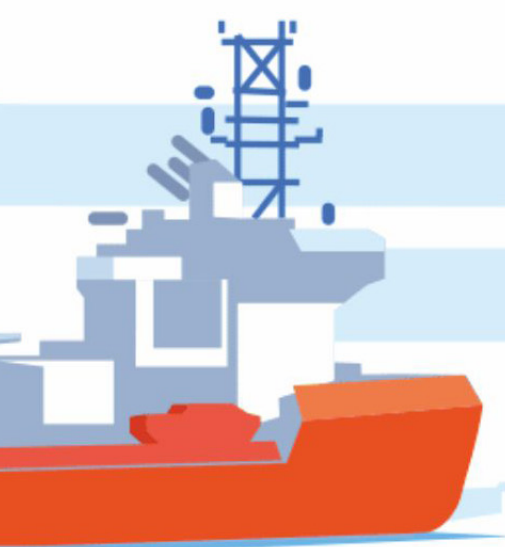

$\frac{11-1}{1 \times 1 \times 2}$

ОРГАНИЗАЦИЯ ИНФФРАСТРУКТУРНОЙ ПОДДЕРНЖКИ АРНТИЧЕСКОЙ НЕФТЕГАЗОВОЙ ОТРАСЛИ

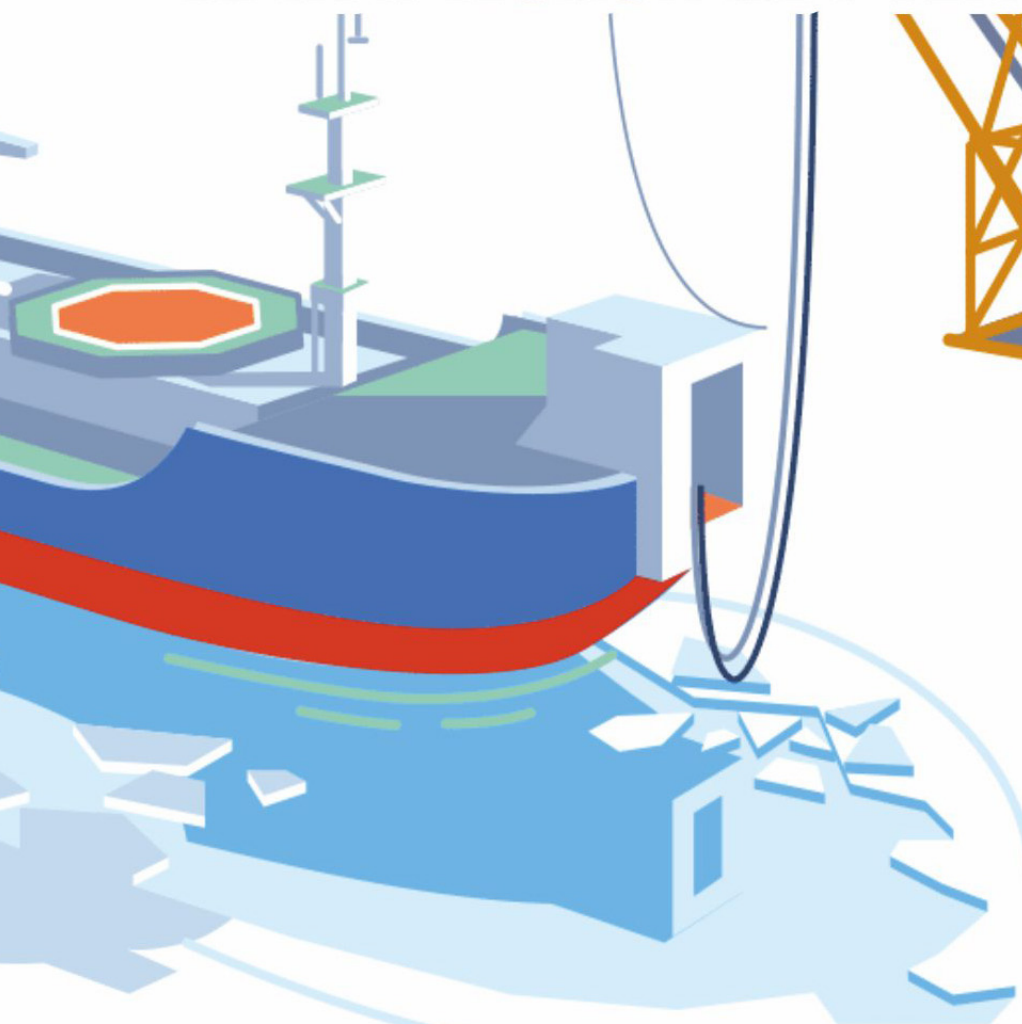


МИНИСТЕРСТВО НАУКИ И ВЫСШЕГО ОБРАЗОВАНИЯ РОССИЙСКОЙ ФЕДЕРАЦИИ ФЕДЕРАЛЬНЫЙ ИССЛЕДОВАТЕЛЬСКИЙ ЦЕНТР «КОЛЬСКИЙ НАУЧНЫЙ ЦЕНТР РОССИЙСКОЙ АКАДЕМИИ НАУК»

ИНСТИТУТ ЭКОНОМИЧЕСКИХ ПРОБЛЕМ ИМ. Г. П. ЛУЗИНА

\section{ОРГАНИЗАЦИЯ ИНФРАСТРУКТУРНОЙ ПОДДЕРЖКИ АРКТИЧЕСКОЙ НЕФТЕГАЗОВОЙ ОТРАСЛИ}

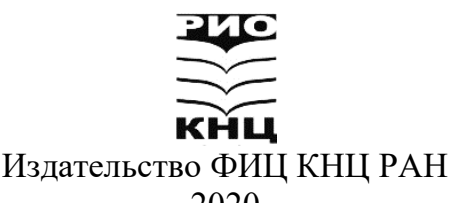

2020 
DOI: $10.37614 / 978.5 .91137 .445 .7$

УДК 338.984

ББК 65

O64

Печатается по решению Редакционно-издательского совета Федерального исследовательского центра «Кольский научный центр Российской академии наук»

Научные редакторы:

доктор экономических наук, профессор В. Ф. Богачев, доктор экономических наук, профессор Н. П. Веретенников

Рецензенты:

доктор экономических наук, профессор А. С. Харланов, доктор экономических наук, профессор Т. Д. Маслова

Коллектив авторов:

В. Ф. Богачев (разделы 1.1, 2.3, 2.4, 4.4, введение, заключение),

Н. П. Веретенников (разделы 4.1-4.3, 5.4), Е. Н. Ветрова (разделы 5.1, 5.2),

С. Ю. Козьменко (разделы 2.1, 5.3), А. Б. Котомин (разделы 1.4, 3.4),

Л. В. Лапочкина (разделы 5.1, 5.2), В. А. Маслобоев (разделы 1.2, 2.2),

А. С. Микуленок (разделы 3.3, 3.4), Р. Р. Садыкова (разделы 3.2-3.4),

М. В. Ульченко (разделы 1.4, 3.1), М. В. Чигирь (разделы 4.3, 4.4),

А. А. Щеголькова (разделы 1.3, 3.2)

О64 Организация инфраструктурной поддержки арктической нефтегазовой отрасли: монография / коллектив авторов; под науч. ред. В. Ф. Богачева, Н. П. Веретенникова. Апатиты: Издательство ФИЦ КНЦ РАН, 2020. — 159 с.: ил.

ISBN 978-5-91137-445-7

Основное внимание уделено анализу состояния нефтегазового комплекса (НГК) Арктической зоны Российской Федерации (АЗРФ), который рассматривается как система, содержащая совокупность подсистем, таких как социально-экономическая, производственная, экологическая, информационная, транспортно-логистическая. Дается анализ перспектив российских производителей на глобальном рынке сжиженного природного газа (СПГ) с позиции диверсификации и модернизации нефтегазотранспортной инфраструктуры; оценка эффективности государственной поддержки российских нефтегазовых проектов в АЗРФ, а также экономической конъюнктуры экспортных поставок арктического СПГ.

Исследуются основные тенденции в формировании и развитии инфраструктуры, формы и методы взаимодействия входящих в ее состав крупных нефтегазовых корпораций, состояние холдинговых и сервисных структур, условия их эффективного взаимодействия. Особое внимание уделено инвестиционной привлекательности проектов, связанных со стратегией развития арктического региона, и созданию организационного механизма повышения доходности предприятий НГК АЗРФ. Подчеркивается негативная роль усиливающихся санкций западных стран в отношении крупнейших российских нефтегазовых компаний в финансовой и технологической сферах, а также роль использования методов недобросовестной конкуренции.

Выделены основные проблемы, препятствующие развитию предпринимательских структур нефтегазового сектора: отсутствие нефтяной биржи, низкое качество нефти, неэффективная законодательная база в области недропользования, налогов, инвестиций. Приведены примеры конкретных проектов в области нефтепереработки.

Монография может быть полезна широкому кругу научных работников, преподавателям, а также специалистам экономики промышленности, природопользования, транспорта и логистики.

Работа выполнена в рамках темы № AАAА-А18118051590116-6 «Взаимодействие глобальных, национальных и региональных факторов в экономическом развитии Севера и Арктической зоны Российской Федерации» по государственному заданию ФИЦ КНЦ РАН (Институт экономических проблем им. Г. П. Лузина). 


\section{ОГЛАВЛЕНИЕ}

ВВЕДЕНИЕ

1.1. Регион как социально-экономическая система.

1.2. Структура и содержание основных элементов отраслевой инфраструктуры

1.3. Анализ перспектив российских производителей на глобальном рынке сжиженного природного газа в современных условиях.....

1.4. Экономическая конъюнктура поставок арктического сжиженного природного газа в страны Азиатско-Тихоокеанского региона......

ГЛава 2. ОСНОВНЫЕ НАПРАВЛЕНИЯ ИНВЕСТИЦИОННОЙ ПОЛИТИКИ

В НЕФТЕГАЗОВОЙ ОТРАСЛИ

2.1. Экономическая сущность инвестиционной политики

2.2. Экономическая эффективность инвестиций в нефтегазовую отрасль.

2.3. Организация и функционирование экономических кластеров

2.4. Система подготовки специалистов и руководителей для промышленности Арктики

ГЛава 3. ПРОМЫШЛЕННЫЕ КОРПОРАЦИИ В НЕФТЕГАЗОВОЙ

ОТРАСЛИ АРКТИКИ

3.1. Формы и методы взаимодействия холдинговой и сервисных структур

3.2. Современное состояние и перспективы развития корпораций на рынке сервисных услуг.

3.3. Условия эффективного взаимодействия структур в системе управления промышленных корпораций.

3.4. Принципы и методы формирования дохода предпринимательских структур

ГЛава 4. РАЗВИТИЕ ЛОГИСТИЧЕСКОЙ ПОДСИСТЕМЫ

РЕГИОНАЛЬНОЙ ИНФРАСТРУКТУРЫ

4.1. Роль и место логистики в инфраструктуре нефтегазового комплекса

4.2. Формирование и развитие логистической инфраструктуры в регионах

4.3. Организация управления транспортно-логистической системой.... 108

4.4. Инфраструктурное обеспечение военной безопасности Арктики... 115

ГЛава 5. ИНФРАСТРУКТУРНЫЕ ПРОЕКТЫ КАК ЭЛЕМЕНТЫ

ПРОМЫШЛЕННОЙ ПОЛИТИКИ АРКТИЧЕСКОГО РЕГИОНА........ 121

5.1. Промышленная политика арктического региона............................. 121

5.2. Разработка и реализация промышленной политики........................... 130

5.3. Оценка экономической эффективности инвестиционного проекта в публичном акционерном обществе «Роснефть»........................ 143

5.4. Организация предприятия по переработке смазочных материалов 146 ЗАКЛЮЧЕНИЕ ......................................................................................... 152

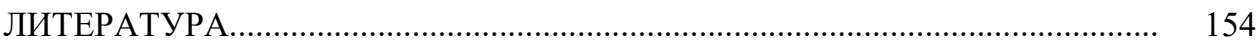




\section{ВВЕДЕНИЕ}

Приход нефтегазовых корпораций в Арктику сформировал социально-экономическую политику, которая зависит от мировых цен на нефть и газ, стадии жизненного цикла месторождения, поиска компромисса между субъектами управления, а также от формирования и развития инфраструктурной поддержки нефтегазовой отрасли в Арктике.

В середине 2000-х гг. произошла череда глобальных преобразований на мировых энергетических рынках: развитие новых инновационных средств морской перевозки природного газа в сжиженном состоянии, технологические новшества в области судостроения танкеров-газовозов. Конструктивные изменения последних привели $к$ достижению приемлемого с позиций экономической конъюнктуры уровня потерь газа при транспортировке на дальние расстояния. В результате новый (морской) вид транспортировки СПГ стал равным по конкурентоспособности основному — трубопроводному, а иногда и превосходящим его.

Инфраструктура народнохозяйственного комплекса - это совокупность отраслей и инженерно-технических сооружений, обслуживающих и создающих условия для размещения и деятельности организаций и компаний различной отраслевой принадлежности, а также условия для проживания населения (транспорт, связь, шоссейные дороги, каналы, водохранилища, мосты, аэропорты, склады, энергетическое хозяйство, водопроводная и водоотводная сети, сфера обслуживания, общее и профессиональное образование и наука, здравоохранение и др.).

Нефтегазовый комплекс включает в себя нефтегазодобывающие предпринимательские структуры (НГДПС) и сервисные предприятия (СП), основным направлением деятельности которых является оказание услуг, специфических для нефтегазового сектора. Интеграция НГДПС и СП в хозяйственную деятельность друг друга базируется на обслуживании потребностей предприятий нефтегазового сектора. Конечным результатом эффективного взаимодействия сервисной и холдинговой предпринимательских структур является извлечение по результатам взаимодействия предпринимательского дохода, который характеризует, в свою очередь, эффективность внедрения и использования инноваций в производственных и управленческих структурах.

Все вышеперечисленные факторы свидетельствуют о значительно возросшей роли инфраструктуры НГК как важнейшего сектора национальной экономики в АЗРФ, который имеет значительный вес в обеспечении общего потребления первичных энергоресурсов, а крупные НГДПС являются главными источниками налоговых поступлений в бюджет России.

Вовлечение в мировой оборот природного газа, разведанного и добытого российскими компаниями на месторождениях в АЗРФ, обеспечивает расширенное воспроизводство его запасов в перспективе, что гарантирует национальную энергетическую безопасность, а также является геополитическим инструментом для укрепления регионального присутствия России в Арктике

Усиливающиеся санкции западных стран в отношении крупнейших российских нефтегазовых компаний в финансовой и технологической сферах, использование методов недобросовестной конкуренции со стороны США не 
стали препятствием для развития самих компаний и их арктических проектов. Критериями такой оценки можно считать низкий уровень долговой нагрузки, положительную динамику инвестиционных программ, соответствующую стадии развития важнейших инвестиционных проектов.

Развитие любой экономики во многом базируется на одной из важнейших составляющих инфраструктуры - логистике. В европейских странах и Америке в последние четыре десятилетия коммерческая логистика стала частью экономики многонациональных компаний. Логистическая цепь, или цепь поставок, представляет собой единую структуру, в которой работает огромное количество предприятий, объединяющих усилия со своими поставщиками, чтобы эффективно доставить товары, услуги и информацию от производителя до потребителей.

Логистика охватывает и объединяет в единый процесс такие разнообразные виды деятельности, как производство, информационный обмен, транспортировка, управление запасами, складское хозяйство, грузопереработка, упаковка и доставка. Оперативная задача логистики любой компании состоит в том, чтобы организовать такое географическое размещение источников сырья, незавершенного производства, запасов готовой продукции, которое отвечало бы потребностям производства и одновременно было бы сопряжено с минимально возможными издержками.

Новые компьютерные технологии и цифровизация процессов ведения хозяйственной деятельности формируют новые возможности организации мониторинга активного промышленного освоения энергетических ресурсов в Арктике. Развитие арктического оборонного комплекса создает фундаментальные предпосылки для устойчивой экономической деятельности в арктических регионах. Таким образом, развитие коммуникаций, наряду с созданием модернизированной военной инфраструктуры, является основой обеспечения национальной безопасности России в Арктике, а для этого требуется поддержание круглогодичного морского сообщения, что невыполнимо без современного, усиленного ледового класса флота и ледоколов.

В связи со стратегической важностью поставленных задач в законодательные документы заложены современные методы управления для эффективного использования значительных государственных и привлеченных капитальных вложений. Планируется создание сети проектных офисов, основным назначением которых будет объединение всех ведомств с целью реализации проектов комплексного развития территории Арктики.

Целью настоящего исследования является обзор и анализ состояния инфраструктуры нефтегазовой отрасли, проблем и подходов к обоснованию приоритетных проектов комплексного развития АЗРФ и методов их государственной поддержки, регулирования и реализации.

Монография подготовлена авторским коллективом в составе: В. Ф. Богачева (разделы 1.1, 2.3, 2.4, 4.4, введение, заключение), Н. П. Веретенникова (разделы 4.1-4.3, 5.4), Е. Н. Ветровой (разделы 5.1, 5.2), С. Ю. Козьменко (разделы 2.1, 5.3), А. Б. Котомина (разделы 1.4, 3.4), Л. В. Лапочкиной (разделы 5.1, 5.2), В. А. Маслобоева (разделы 1.2, 2.2), А. С. Микуленока (разделы 3.3, 3.4), Р. Р. Садыковой (разделы 3.2-3.4), М. В. Ульченко (разделы 1.4, 3.1), М. В. Чигирь (разделы 4.3, 4.4), А. А. Щегольковой (разделы 1.3, 3.2). 


\section{ГЛава 1. ОРГАНИЗАЦИОННЫЕ ОСНОВЫ ФОРМИРОВАНИЯ ИНФРАСТРУКТУРЫ НЕФТЕГАЗОВОГО КОМПЛЕКСА АРКТИКИ}

\section{1. Регион как социально-экономическая система}

Во многих трудах отечественных и зарубежных авторов встречаются попытки раскрыть содержание понятия «регион», который они определяют, исходя из различных критериев. Самый, пожалуй, известный исследователь проблем региональной экономики - А. Г. Гранберг — трактует регион как часть территории, имеющей существенные отличия от других территориальных объединений, характеризующейся определенными чертами с наличием некоей целостности и взаимосвязанности компонентов. Согласно его концепции, регион представляет собой территорию как четко сформированную социально-экономическую систему, т. е. как совокупность взаимозависимых и взаимодействующих ресурсов, а также субъектов экономической и социальной сферы [23]. В данной трактовке за основу принимается перевод самого слова «регион», который в первоисточниках означает «страна, край, область».

В современном экономическом словаре термин «регион» обозначает области, районы, территории, части страны, которые отличаются экономикогеографическими условиями, сформировавшимися исторически или естественным путем, а также демографическим и национальным составом населения. В условиях необходимости построения сложной, многоуровневой взаимосвязи между различными элементами национальной экономической системы России и в целях построения новой системы внутрироссийского разделения труда по территориальному (а не отраслевому) признаку, понятие «регион» должно коррелировать с такими понятиями, как «федеральный округ», «муниципальное образование» и пр.

Ряд ученых в трактовке понятия «регион» выделяют два подхода: географический и экономический. В рамках географического подхода под регионом понимается «часть территории, которая «обладает некоторой целостностью», отличающаяся совокупностью естественных или исторически сложившихся условий и национальным составом населения и, конечно же, имеющая определенные границы, но не только административно-территориальные, но и географические, экономические или социокультурные. В глобальном масштабе регион, как отмечалось выше, можно определить, как группу близлежащих стран, представляющих собой отдельный экономико-географический район, обладающий общими признаками, отличающими этот район от других районов» [23]. Такой подход не позволяет определить регион как изменяющуюся во времени и пространстве субстанцию, затрудняет понимание процессов укрупнения или, напротив, разукрупнения территориальных образований в соответствии с характером современных внутренних и внешних вызовов, с которыми сталкивается национальная экономика.

При экономическом подходе понятие «регион» рассматривается как относительно самостоятельная система с составляющими ее элементами 
и экономическими взаимосвязями между ними. Эти элементы образуют единое целое, обладающее свойствами, не присущими составляющим его компонентам, взятым в отдельности. В качестве таких общесистемных свойств могут выступать целостность, иерархичность и интегративность.

Существует и политический подход к определению региона. Так, в принятой по инициативе Ассамблеи регионов Европы Декларации о регионализме в Европе регион определяется как «выражение отличительной политической самостоятельности, которая может принимать самые различные политические формы, отражающие демократическую волю каждого региона, принимать ту форму политической организации, которую он сочтет предпочтительной» [66].

Зарубежные ученые также не пришли к единой точке зрения в отношении определения понятия «регион». Практический и научный интерес к районированию территорий существует не только в России и США. Значимость и серьезность вопроса постоянно обсуждается ведущими специалистами в Китае, Канаде, Франции, Германии, Великобритании, а также во многих других странах. Так, американский экономист Л. Туроу справедливо отмечает, что «пространственная карта мира теперь строится в соответствии с концентрацией человеческого капитала, разломы на ней определяются не столько государственными или административными границами, сколько «культурными» разломами» [83]. Нельзя, однако, согласиться с предполагаемым Л. Туроу размыванием «государственных или административных» границ в современных условиях, но, вместе с тем, «человеческий фактор» и его «концентрация», безусловно, являются важными составляющими новой модели внутренней пространственнотерриториальной организации общества.

В уже упомянутой и принятой к исполнению на территории ЕС Декларации о регионализме, согласно нормативным актам и регламентам, изданным и имеющим силу на территории Европейского союза, к региону относятся территории, имеющие очевидную общность с точки зрения географического расположения и обладающие преемственностью, с населением, придерживающимся определенных человеческих ценностей и стремящимся сохранить и развивать собственную идентичность с целью стимулирования экономического, социального и культурного прогресса.

Проведенный анализ подходов к определению понятия «регион» позволяет сделать вывод, что обычно под этим понятием подразумевается определенная территория, причем признаки, которые позволяют еe идентифицировать, могут значительно различаться, но должна существовать взаимосвязь и взаимодействие между элементами, входящими в регион. Большинство авторов склоняются к тому, что понятие «регион» можно охарактеризовать как территориальную структуру, которая обладает рядом общностей природно-климатических и экономических условий хозяйствования. В нашем случае за регион принимается субъект в составе Российской Федерации, т. е. образование, способное в соответствии с представленными полномочиями реализовывать экономическую политику в определенных сферах. На основании вышесказанного, в целях достижения единой трактовки сущности и конкретных характеристик региона, наиболее целесообразным при определении категории «регион» будет использование 
принципов системного подхода. Большое значение для стратегического развития российской экономики имеет новое качество взаимосвязи между элементами, составляющими как региональную, так и национальную экономические системы. В рыночных условиях эта связь является многосложной, многоуровневой, одну из граней которой цитируемые выше исследователи определяют как «региональная экономика» (мезоуровень), которая служит связующим звеном между государством (макроуровнем) и отраслями предприятий и домохозяйств (микроуровнем), т. е. она создает условия для развития всех микросистем и в то же время не идет вразрез с экономической политикой государства.

В этой связи особенно значимо то, что в современной федеративной России реализация региональной политики неизбежно приобретает ряд уровней, которые укрупненно можно представить следующим образом. Первый уровень должен реализовываться органами государственной власти Российской Федерации. Здесь требуется формирование государственной федеральной политики регионального развития страны, включая сферы и пространства ее жизненно важных интересов за ее пределами. Второй уровень - федеральные округа как субъекты и трансляторы государства в регионах. Третий уровень - объединение субъектов Федерации (например, уже существующие межрегиональные ассоциации экономического взаимодействия), выступающие не только механизмами посредничества между федеральными органами и субъектами Федерации, но и субъектами региональной политики. Четвертый уровень - субъекты Российской Федерации, проводящие во многих сферах жизнедеятельности собственную региональную политику. Пятый уровень - объединение субъектов местного самоуправления муниципальных образований. Шестой уровень - субъекты местного самоуправления, которые в меру своей компетенции осуществляют местную (локальную) социальноэкономическую политику. В данном подходе представлен пример многослойности внутренней организации российского экономического пространства, различные уровни в иерархии внутрироссийского разделения труда, определяющие высокую значимость идентификации задач и ресурсов по их осуществлению на каждом из представленных уровней. Поиск такой взаимосвязи, по нашему мнению, представляет огромное значение для построения новой модели общероссийского экономического пространства и повышения устойчивости России в условиях нестабильной внешней среды. Как справедливо замечает А. Г. Гранберг, «переход к рыночной экономике и реальному федерализму сопровождается тем, что каждый регион - субъект Федерации становится экономической подсистемой с сильной взаимосвязанностью своих основных элементов» [23].

По нашему мнению, под регионом следует понимать относительно самостоятельную, целостную экономическую систему, обладающую определенным и однородным набором природных ресурсов в сочетании c накопленным человеческим капиталом (для создания уникальных, конкурентоспособных товаров), а также интегрирующуюся с другими регионами в целях поддержания устойчивости единого экономического пространства.

В определении целей и задач развития региональной экономики также существует значительный разброс взглядов и мнений. Так, О. В. Дьякова и Б. И. Герасимов считают, что «основной целью функционирования 
региональной экономики является обеспечение высокого уровня и качества жизни населения соответствующего региона» [27]. С ними солидарен Ю. А. Гонтарь, утверждающий, что «важнейшим аспектом, характеризующим воспроизводственные процессы на региональном уровне, является необходимость удовлетворения потребностей населения данного региона в товарах и услугах, обеспечение условий нормального воспроизводства социума, населяющего регион» [22]. Нам представляется не совсем точным такое высказывание, которое несет в себе оттенки общественного иждивенчества и отражает в некотором смысле критикуемый данным автором перераспределительный подход к региональному развитию. Важен не столько конечный результат, выраженный в конкретном продукте или услуге, сколько процесс непрерывного развития региона, поддержание его креативности и динамизма не только в постановке новых целей в условиях меняющейся среды, но и в формировании разнообразных подходов к их достижению. В этом смысле целью развития региона является непрерывное поддержание инновационных способностей, т. е. способностей по созданию, внедрению, коммерциализации и диффузии новых технологий, повышающих устойчивость развития региона и создающих более высокие возможности для удовлетворения разнообразных внутренних (в том числе социальных) потребностей. Кроме того, в таком подходе к определению стратегии регионального развития отражена не только цель - экономический рост (количественно), но и его качественная основа (научно-техническое развитие региона), а также ответственность региона за укрепление общероссийского пространства (в противовес традиционному представлению о том, что центр несет ответственность за экономическую и социальную стабильность в регионе).

Региональный уровень имеет принципиально большое значение при принятии эффективных правительственных решений для многих стран, особенно для тех, которые находятся в условиях глубокой трансформации своей экономической, социальной, политической и технологической структуры. Экономическая активность во все возрастающей степени основывается на конкуренции, укрепляет партнерство и стимулирует интерактивные инновации. Это имеет место как среди менеджмента и рабочих, так и среди фирм в отношении их сотрудничества в условиях конкуренции; между малыми и средними фирмами, а также их системами управления на национальном и региональном уровнях. При этом значение локального и регионального социального окружения как медиатора экономической координации возрастает.

Именно региональный уровень является для современной экономики отправной точкой для поиска наиболее оптимальной стратегии экономического роста. Это тот уровень, на котором должно первоначально произойти сочетание промышленной и технологической политики, вписывающейся в стратегию экономического роста региона. Только после этого возможно определение макроэкономической политики, создающей внешние по отношению к региону благоприятные условия для его роста, a также позволяющей координировать политику, направленную на оптимизацию межрегиональных связей, развитие внутреннего рынка и национальной экономики в целом. Как справедливо отмечают А. Н. Авдулов и А. М. Кулькин: «...примерно с конца 70-х — начала 80-х годов регионализация научно-технической политики, передача ряда полномочий 
в этой сфере от центра в регионы, активное подключение местных властей к «наукофикации» экономики на подопечных территориях стали одним из важнейших направлений деятельности правительства США, Японии, ФРГ, Франции» [1]. К сожалению, данная проблематика практически не исследована современными отечественными и зарубежными специалистами, что, на наш взгляд, значительно затрудняет продвижение экономических реформ во многих странах, прежде всего в странах бывшего социалистического блока. «Существует несколько причин, по которым происходит отрицание технологии в принятии решений на региональном уровне. Для многих политиков технологии часто рассматриваются как нечто, находящееся за пределами политического интереса из-за их сложности и отсутствия очевидной связи с более важными социально-экономическими проблемами. Другим фактором является трудность в понимании связи между технологиями и региональным и национальным развитием или с проблемами экономической конкурентоспособности. Также существует не менее важная, хотя и реже отмечаемая причина, состоящая в том, что технологическое развитие требует длительного периода времени, которое обычно находится за пределами краткосрочных интересов большинства политиков» [31].

Во многих отечественных исследованиях различных вариантов стратегий регионального развития практически не рассматривается их связь c прогрессом региональной технологической системы. Как отмечает О. В. Козловская, исследование вопроса становления стратегии регионального развития показало, что все имеющиеся подходы к анализу социальноэкономического развития российских регионов можно условно разделить на группы [31]. Первую группу составляют исследования в области устойчивого развития региональной экономики в условиях становления отношений между центром и регионами, развития нормативно-правовой базы и механизмов бюджетно-налогового регулирования регионального воспроизводства. Вторая группа подходов основана на анализе неравномерности и несбалансированности процессов воспроизводства в российских регионах. Предметом изучения здесь выступает возможность расширения объемов регионального выпуска вместе с ростом в сфере производства и потребления, увеличением частных инвестиций и повышением уровня жизни. Третья группа подходов основана на анализе системы бюджетно-финансовых и инвестиционно-кредитных факторов этого процесса. Четвертая группа содержит комплексный анализ дореформенного и зарубежного опыта становления программного начала рыночных реформ, в том числе и на уровне региона.

В современных условиях как никогда возрастает потребность в формировании концепции региональной экономической политики в России, которая должна способствовать не только преодолению проблем в экономическом развитии отдельных регионов, усилению интеграционного взаимодействия между ними и укреплению единого экономического пространства, но и усилению позиций страны в мировой экономике.

В предшествующий рыночным реформам период основным принципом политики, проводимой в отношении регионов, являлось выравнивание регионального развития (т. е. достижение сравнительно равного уровня социально-экономического развития в результате «подтягивания» экономически слабых регионов к уровню наиболее сильных). В условиях 
рыночных преобразований, особенно в последнее время, все более популярной становится концепция «поляризации» регионов, т. е. выделение сильных регионов («локомотивов», «доноров», «полюсов роста») и слабых регионов при обосновании необходимости концентрации ресурсов (прежде всего финансовых) именно в сильных регионах. Рассмотрим первый подход.

В советский период стремление к равномерному развитию территорий определялось не только потребностью максимально задействовать огромные ресурсные и территориальные возможности в целях развития крупномасштабного промышленного (прежде всего военного) производства, но и поддержанием безопасности страны. Выравнивание достигалось «применением к системе регионов известного правила оптимизации - "равная предельная производительность ресурсов по всем направлениям их использования"» [22, с. 185]. В советский период регионы рассматривались как совокупность географически сопряженных производственно-технических площадок, совместно обеспечивающих сбалансированность и самодостаточность экономики, ее динамичный рост. В силу этого региональное развитие страны осуществлялось как плановое размещение на территории производительных сил. Поскольку выравнивание понималось как «приоритетное финансирование депрессивных регионов и концентрация в них бюджетных средств...», то делается вывод о том, что «административные и институциональные механизмы государственного управления региональным развитием во многом утратили свою эффективность, в контексте использованных инструментов достигнут предел эффективности политики выравнивания». Более того, выравнивание стало препятствовать появлению на территории России инновационных центров и снижать общую конкурентоспособность страны. Регионы-лидеры стали терять мотивацию к развитию, а среди остальных территорий начали проявляться иждивенческие настроения.

\section{2. Структура и содержание основных элементов отраслевой инфраструктуры}

Нефтяная и газовая промышленность является в настоящее время важнейшей частью топливно-энергетического комплекса страны. Создание основных фондов для этих отраслей - главная задача нефтегазового строительства, продукцией которого являются законченные и подготовленные к вводу в эксплуатацию новые или реконструированные сооружения (трубопроводы, насосные станции, системы поддержания пластового давления, установки комплексной подготовки нефти и газа и др.), а также жилые социально-культурные и бытовые здания и объекты. Все это объединяется общим понятием «инфраструктура».

Инфраструктура народнохозяйственного комплекса - это совокупность отраслей хозяйства и инженерно-технических сооружений, обслуживающих и создающих условия для размещения и деятельности промышленного и сельскохозяйственного производства (или отдельных их предприятий), а также для размещения и жизни населения. Это транспорт, связь, шоссейные дороги, каналы, водохранилища, мосты, аэропорты, склады, энергетическое хозяйство, водопроводная и водоотводная сеть, сфера обслуживания, общее и профессиональное образование и наука, 
здравоохранение и др. Различают инфраструктуру производственную, социальную, экологическую, информационную.

Производственная инфраструктура включает в себя отрасли, непосредственно обслуживающие материальное производство. Современные нефтегазодобывающие предприятия представляют собой сложные комплексы технологических объектов, рассредоточенных на больших площадях, размеры которых достигают десятки и сотни квадратных километров. Технологические объекты - скважины, групповые измерительные и сепарационные установки, сборные пункты, установки комплексной подготовки нефти и газа, резервуарные парки - связаны между собой через продуктивный пласт и поток продукции, циркулирующий по технологическим коммуникациям.

Социальная инфраструктура - это отрасли, опосредовано связанные с процессом производства (жилые дома, сеть учреждений культуры, просвещения, медицинского обслуживания, предприятия торговли и общественного питания и т. д.). В последнее время в понятие «инфраструктура» иногда включают (под названием метаинфраструктура или экологическая инфраструктура) природные ресурсы и условия жизни общества.

Экологическая инфраструктура - это комплекс сооружений, предприятий, учреждений, сети и технологические системы, обеспечивающие условия сохранения среды жизни человека (среды, окружающей человека). Она включает в себя элементы традиционных производственной и социальной инфраструктур (особенно последней); сооружения, предприятия, учреждения, предупреждающие и ликвидирующие неблагоприятные явления природы и социального дискомфорта (систему мониторинга, очистные сооружения, охрану лесов, плотины, дамбы, дренаж, коммунальное хозяйство, сферу обслуживания и т. п.), а также совокупность природных, особо охраняемых территорий (заповедники, заказники, национальные и природные парки, зеленые зоны, парковые и защитные леса, памятники природы и т. д.).

Информаиионная инфраструктура включает в себя развитую сеть информационных элементов, которые не принимают непосредственного участия в производстве материальных благ, но им принадлежит огромная роль в обеспечении процесса производства, ибо без информационного обслуживания не может нормально функционировать основное производство.

Поэтому развитие инфраструктуры, определение правильных пропорций между основным производством и его отраслями имеют большое значение для его планирования и организации, а также для рационального использования материальных, трудовых и финансовых ресурсов, размещения производительных сил, повышения эффективности всего производственного процесса.

При поступательном развитии ключевых экономических процессов внутри страны особую роль играют предпринимательские структуры, формирующие инновационную основу единой системы региона. Совокупность предпринимательских структур региона, государственных, муниципальных, а также частных организаций, обеспечивающих целостность инфраструктуры для поступательного развития хозяйственной деятельности в регионе, представляют собой в общем виде региональную инфраструктуру экономики. В этой системе в рыночных условиях важную роль играют предпринимательские структуры, включающие малый и средний бизнес, оказывающие всевозможные услуги крупным газо- и нефтедобывающим корпорациям. 
Нефтегазовый комплекс обеспечивает жизнедеятельность всех отраслей национального хозяйства страны, способствует консолидации субъектов Российской Федерации, во многом определяет формирование основных финансово-экономических показателей страны. Поэтому он должен быть финансово устойчивым, экономически эффективным и динамично развивающимся, соответствующим экологическим и социальным стандартам, оснащенным передовыми технологиями и высококвалифицированными кадрами на всех уровнях производства.

Для долгосрочного, стабильного развития экономики, предпринимательства, а также для обеспечения населения страны всеми видами энергии необходима научно обоснованная и одобренная обществом и институтами государственной власти долгосрочная социально-экономическая энергетическая политика. Основной целью энергетической политики в экономике государства, которую проводит Правительство Российской Федерации, является максимально эффективное и целесообразное использование природных топливноэнергетических ресурсов и потенциала НГК для роста экономики и повышения качества жизни граждан и хозяйствующих субъектов страны.

$$
\text { Значение НГК для жизнедеятельности населения }
$$

и функционирования экономики предпринимательства таково, что в современных макро- и микроэкономических условиях обойтись без него невозможно. В свою очередь, состояние НГК зависит от масштабов находящейся в его распоряжении и доступности сырьевой базы. Россия является крупной энергетической державой, обладающей $13 \%$ мировых запасов нефти, 45 \% газа. Данные Emergency Operations Group подтверждают, что Россия является одним из крупных держателей запасов в структуре общемирового хозяйства (рис. 1.) В данные на рис. 1 не вошли потенциальные запасы Арктического шельфа Российской Федерации.

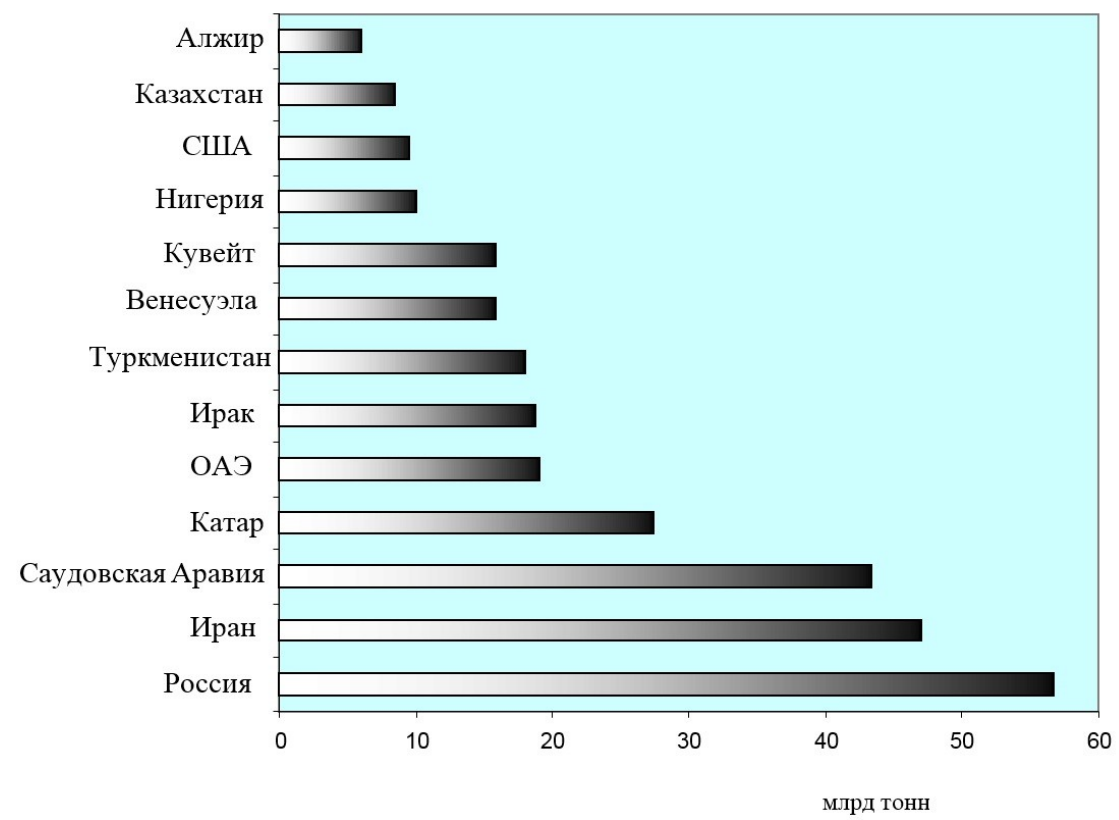

Рис. 1. Мировые запасы нефти и газа (млрд т) 
Структура потребления первичных энергоресурсов в мировом хозяйстве в 2018 г. представлена в табл. 1 (рассчитано авторами), a сравнительный анализ структуры мирового потребления первичных энергоресурсов во времени с перспективой на 2030 г. — на рис. 2.

Таблица 1

Структура потребления топливных ресурсов в 2018 г.

\begin{tabular}{|l|c|}
\hline \multicolumn{1}{|c|}{ Топливо } & $\begin{array}{c}\text { Структура потребления первичных } \\
\text { энергоресурсов, \% }\end{array}$ \\
\hline Нефть & 42,6 \\
\hline Твердое топливо & 25,3 \\
\hline Газ & 22,8 \\
\hline Атомная энергия & 8,2 \\
\hline Прочие нетрадиционные источники & 1,1 \\
\hline
\end{tabular}

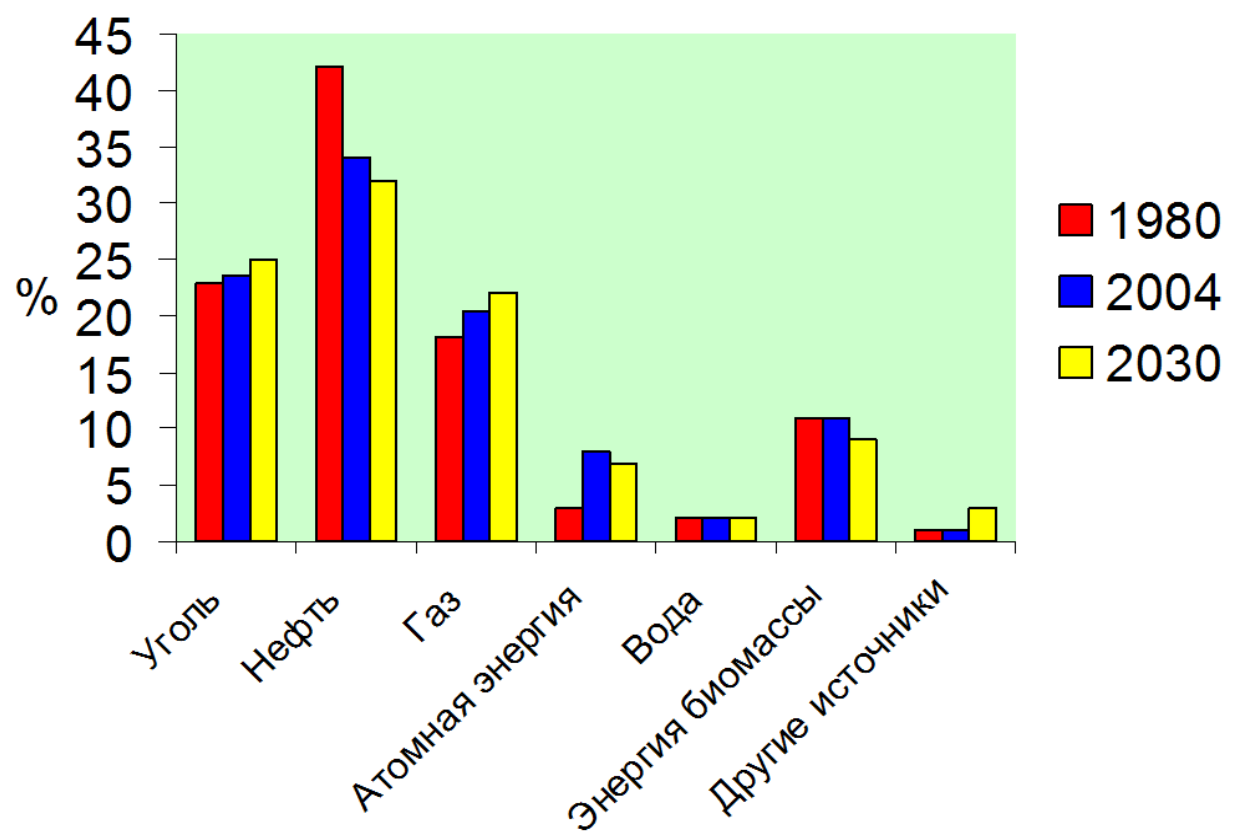

Рис. 2. Сравнительный анализ структуры мирового потребления первичных энергоресурсов за 1980, 2004, 2030 гг. (рассчитано авторами)

Таким образом, из табл. 1 видно, что наибольший удельный вес в структуре потребления первичных энергоресурсов имеет нефть.

Перспективы экономического роста России в большей степени зависят от более эффективного и целесообразного использования энергоресурсов. Потребление энергии на душу населения в различных странах мира представлено на рис. 3 (составлено авторами). 


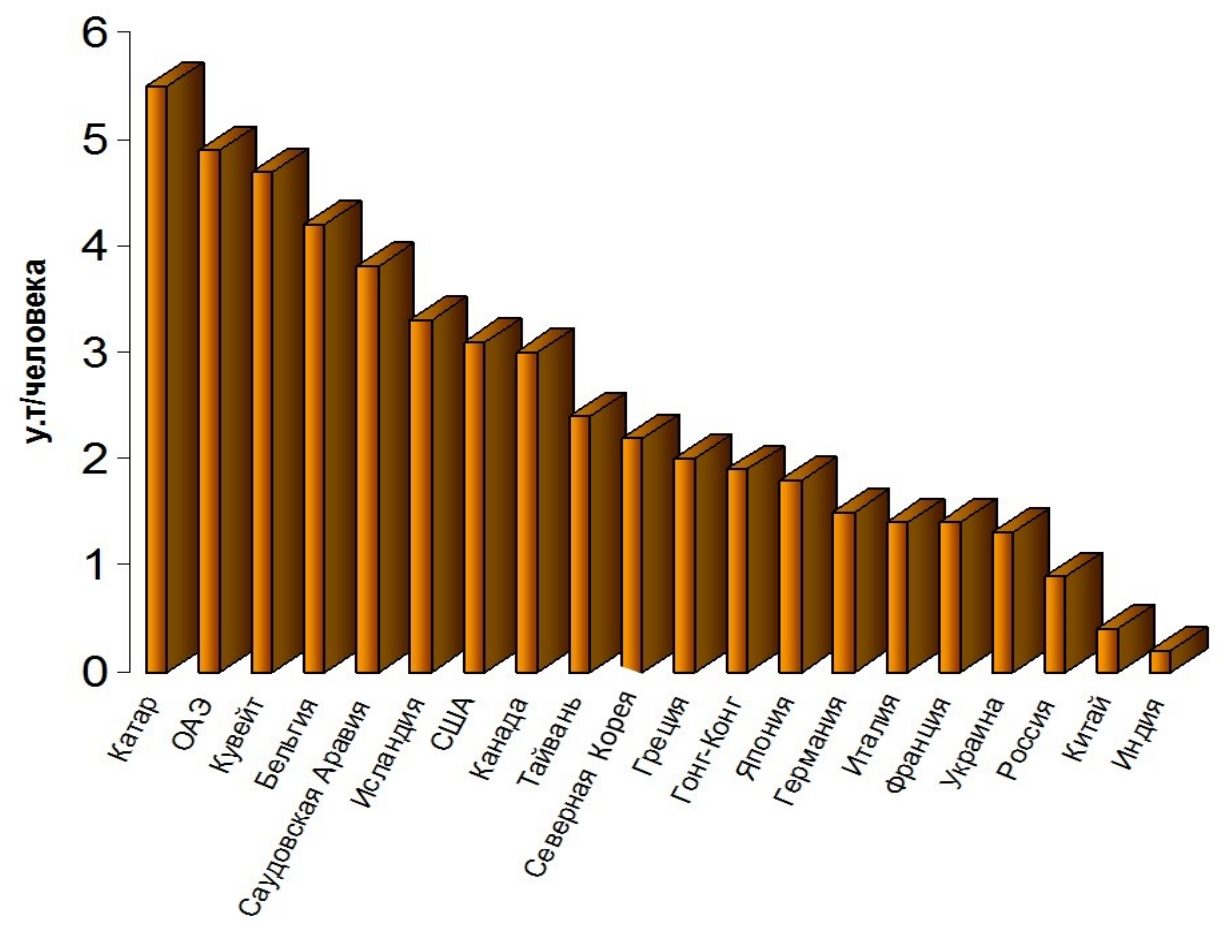

Рис. 3. Потребление энергии на душу населения в различных странах

Структуру поступлений налога на добычу полезных ископаемых (НДПИ) в консолидированный бюджет Российской Федерации в 2018 г. наглядно можно увидеть на рис. 4.

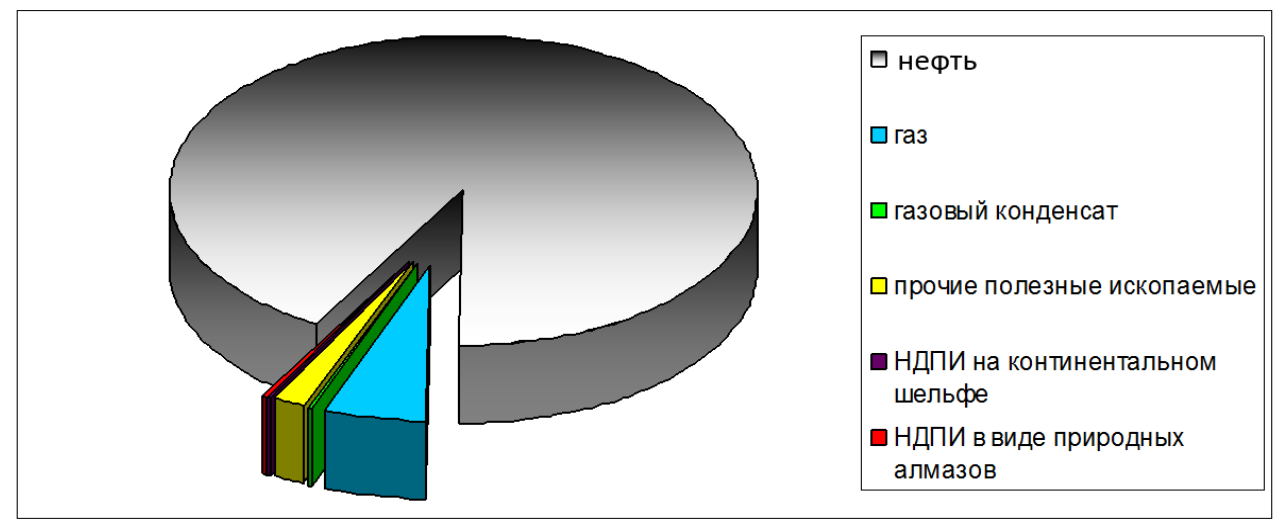

Рис. 4. Структура поступлений НДПИ в консолидированный бюджет Российской Федерации в 2018 г. (рассчитано авторами)

Все вышеперечисленные факторы свидетельствуют о значимой роли НГК как важнейшего сектора национальной экономики, который имеет огромный вес в общем потреблении первичных энергоресурсов, а крупные НГДПС являются главными источниками налоговых поступлений в федеральный бюджет России. Все это способствует функционированию 
всех отраслей народного хозяйства, вносит решающий вклад в формирование основных финансово-экономических показателей страны, усиливает интеграцию экономических субъектов.

\section{3. Анализ перспектив российских производителей на глобальном рынке сжиженного природного газа в современных условиях}

Возрастание мирового потребления энергетических ресурсов предполагает активизацию экономической деятельности в сфере освоения регионального пространства Арктики, которое обладает уникальным природно-ресурсным и инфраструктурным потенциалом. Поэтому освоение Арктики является приоритетом обеспечения национальной безопасности Российской Федерации. Социально-экономическое развитие Арктики осуществляется в двух основных направлениях: широкое освоение минерально-сырьевого потенциала и развитие системы арктических коммуникаций.

Оценка структуры запасов и потенциальных ресурсов природного газа. Россия сохраняет лидерство по разведанным запасам природного газа (19,8 \% общемировых), а также по объемам экспорта (около 20 \% мирового объема). Рост экспорта был обеспечен преимущественно увеличением поставок трубопроводного газа в страны Западной Европы, а также расширением производства и экспорта СПГ за счет проекта «Ямал СПГ».

В последние годы активизированы усилия по освоению месторождений углеводородных ресурсов в российской части Арктики. Определена общая геологическая структура изученных шельфовых зон, раскрыты основные параметры нефтегазоносности, установлены структурные элементы и тенденции изменения мощностей осадочного чехла. Выявлена средняя плотность извлекаемых начальных суммарных ресурсов углеводородов, которая составляет 20-25 тыс. т/км². По итогам 2018 г. добыча природного газа в Российской Федерации составила 733 млрд м ${ }^{3}$, прирост запасов природного газа (по категориям $\mathrm{A}+\mathrm{B} 1+\mathrm{C} 1)$ на территории России в результате геолого-разведочных работ (ГРР) составил 796,6 млрд м². Таким образом, коэффициент воспроизводства природного газа в Российской Федерации в 2018 г. составил порядка 1,09.

Экономическая конъюнктура России на мировом рынке СПГ. В 2018 г. на глобальном рынке СПГ зафиксирован очередной рекорд его производства - 313,8 млн т (рост по сравнению с 2017 г. - 9 \%). Россия вслед за США и Австралией вошла в тройку мировых лидеров по росту производства СПГ, потеснив Алжир и Индонезию. Используя статистические данные, представленные BP Statistical Review of World Energy за период 2014-2018 гг. [78], а также данные International Group of Liquefied Natural Gas Importers за 2018 г. [79], был рассчитан коэффициент роста экспорта СПГ за период 2014-2018 гг. по основным странам-экспортерам (табл. 2). 
Темпы роста производства СПГ по странам-лидерам

\begin{tabular}{|c|c|c|c|c|c|c|}
\hline \multirow[b]{2}{*}{ Страна } & \multicolumn{4}{|c|}{ Цепные темпы прироста, \% } & \multirow{2}{*}{$\begin{array}{c}\text { Базисный } \\
\text { темп } \\
\text { прироста, } \\
\text { \% } \\
\end{array}$} & \multirow{2}{*}{$\begin{array}{c}\text { Коэффициент } \\
\text { роста экспорта } \\
\text { СПГ } \\
\text { за 2014-2018 гг. }\end{array}$} \\
\hline & $\begin{array}{c}2014 / 2015 \\
\text { ГГ. }\end{array}$ & $\begin{array}{c}2015 / 2016 \\
\text { ГГ. }\end{array}$ & $\begin{array}{c}2016 / 2017 \\
\text { ГГ. }\end{array}$ & $\begin{array}{c}2017 / 2018 \\
\text { ГГ. }\end{array}$ & & \\
\hline США & 40,0 & 514,3 & 304,6 & 63,8 & 5600,0 & 2,75 \\
\hline Австралия & 15,1 & 55,4 & 28,2 & 21,1 & 177,6 & 1,29 \\
\hline Россия & 1,40 & 1,2 & 5,7 & 63,2 & 76,9 & 1,15 \\
\hline Индонезия & $-4,6$ & 7,2 & $-2,3$ & 15,7 & 15,7 & 1,04 \\
\hline Нигерия & 8,7 & $-13,8$ & 17,3 & $-2,3$ & 7,4 & 1,018 \\
\hline Катар & $-1,1$ & 5,3 & $-3,5$ & 2,5 & 3,0 & 1,007 \\
\hline Малайзия & 0,9 & $-6,1$ & 12,5 & $-5,8$ & 0,3 & 1,001 \\
\hline Алжир & $-5,1$ & $-4,8$ & 5,1 & $-16,3$ & $-20,6$ & 0,94 \\
\hline
\end{tabular}

По прогнозам, в текущем году новые СПГ-проекты увеличат поставки сжиженного газа из США почти на 20 млрд м ${ }^{3}$, из России - на 12 млрд м ${ }^{3}$, из Австралии - на 9 млрд м³. По мнению многих экспертов, текущий избыток мирового предложения СПГ - долгосрочный тренд, однако необходимо учитывать имеющиеся прогнозы об отмене (отсрочке) новых СПГ-проектов в мире, дефицит танкеров, а также инвестиционные циклы в СПГ-индустрии. Таким образом, данные факторы нивелируют влияние избыточного производства СПГ. По прогнозам экспертов, экологическая повестка, актуальная на сегодняшний день, растущий спрос на рынке стран АТР и иные факторы приведут к росту спроса на СПГ со среднегодовым темпом от 3,3 до 5,5\%. Наиболее оптимистичные взгляды разделяют Shell, IEA, а также BP, ожидающие, что к 2025 г. мировое потребление СПГ достигнет 586,6 и 615,6 млрд м ${ }^{3}$ соответственно. Россия поставляет СПГ во все регионы мира, включая страны Америки и Ближнего Востока, поставки в которые в 2018 г. составили 0,79 и 0,63 млрд м ${ }^{3}$ соответственно. В табл. 3 представлены лидеры по поставкам СПГ по регионам мира [78, 79].

Таблича 3

Лидеры по поставкам СПГ по регионам мира, млрд м $^{3}$

\begin{tabular}{|c|c|c|c|c|}
\hline Рейтинг & АТР & Европа & Страны Америки & $\begin{array}{c}\text { Ближний } \\
\text { Восток }\end{array}$ \\
\hline \multirow{2}{*}{$\mathbf{1}$} & Австралия & Катар & Тринидад и Тобаго & Катар \\
& $\mathbf{9 1 , 8 4}$ & $\mathbf{2 2 , 6 6}$ & $\mathbf{9 , 1 2}$ & $\mathbf{3 4 4}$ \\
\hline \multirow{2}{*}{$\mathbf{2}$} & Катар & Алжир & США & США \\
& $\mathbf{7 8 , 3 7}$ & $\mathbf{1 2 , 8 2}$ & $\mathbf{8 , 0 7}$ & $\mathbf{1 , 8 9}$ \\
\hline \multirow{2}{*}{$\mathbf{3}$} & Малайзия & Нигерия & Нигерия & Нигерия \\
& $\mathbf{3 4}$ & $\mathbf{1 2 , 5 2}$ & $\mathbf{2 , 2 8}$ & \\
\hline \multirow{2}{*}{$\mathbf{4}$} & Индонезия & Россия & Катар & \\
& $\mathbf{2 4 , 9 7}$ & $\mathbf{6 , 1 1}$ & $\mathbf{1 , 6 3}$ & \\
\hline \multirow{2}{*}{$\mathbf{5}$} & Россия & Норвегия & & \\
& $\mathbf{1 7 , 7 5}$ & $\mathbf{4 , 7 9}$ & & \\
\hline
\end{tabular}


Рост поставок СПГ осуществлен за счет реализации СПГ-проектов, включая «Ямал СПГ». Стоит отметить, что до запуска «Ямал СПГ», т. е. еще в 2017 г., наша страна практически не продавала сжиженный газ на Запад. По данным Федеральной таможенной службы России [75], совокупная выручка от поставок российского СПГ в 2018 г. составила 5,286 млрд долл. США (темпы роста по сравнению с 2017 г. составили 166,6 \%). В то же время экспорт трубопроводного газа принес нашей стране 49,147 млрд долл. США, т. е. в 9,3 раза больше. На 1 января 2019 г. на полуострове Ямал открыто 32 месторождения углеводородного сырья. Суммарные запасы и ресурсы всех месторождений полуострова Ямал: 26,5 трлн м газа, 1,6 млрд т газового конденсата и 300 млн т нефти. По экспертным оценкам, на месторождениях Ямальской нефтегазоносной области (НГО) к 2030 г. будет производиться до 360 млрд м ${ }^{3}$ природного газа [54]. Ямальский нефтегазоносный центр включает три промышленные зоны, объединенные в рамках мегапроекта «Ямал»: Бованенскую (Бованенское, Харасавэйское, Крузенштернское месторождения); Тамбейскую (Северо-Тамбейское, Западно-Тамбейское, Тасийское, Малыгинское, Южно-Тамбейское и Сядорское месторождения); Южно-промышленную (Новопортовское, Нурминское, Мало-Ямальское, Ростовцевское, Арктическое, Средне-Ямальское, Хамбатейское, Нейтинское, Каменномысское месторождения). Зона СПГ выделена на ресурсной базе Южно-Тамбейского газоконденсатного месторождения, который, по оценкам экспертов, характеризуется запасами природного газа в 1,3 трлн м ${ }^{3}$, газового конденсата - более 60 млн т [73, с. 119].

Развитие маситабных газовых проектов в Российской Арктике c позиции диверсификации и модернизации газотранспортной uнфраструктуры. Эксплуатация Южно-Тамбейского месторождения осуществляется компанией «Ямал СПГ». Оператор проекта - компания «Ямал СПГ», ее акционерами являются ПАО «Новатэк» (50,1 \%), СNPC (20\%), Total $(20 \%)$ и китайский Фонд шелкового пути $(9,9 \%)$. Совокупная мощность «Ямал СПГ» составляет 16,5 млн т в год. В декабре 2020 г. ожидался ввод четвертой опытно-промышленной очереди «Ямал СПГ» мощностью 0,95 млн т, которая в первоначальном проекте не была предусмотрена. В соответствии со стратегией ПАО «Новатэк» предполагается к 2030 г. достичь производства СПГ на уровне 55-57 млн т, при этом с учетом геологоразведки в рамках имеющихся месторождений производство может достичь 70 млн т. Мощность проекта «Ямал СПГ» сравнима с объемом транспортировки природного газа через Украину [73].

Доставка СПГ на рынки стран АТР осуществляется в летний период по Северному морскому пути (СМП), в зимний - по западному маршруту с перевалкой СПГ на одном из европейских регазификационных терминалов. Обслуживание проекта в данный момент осуществляется газовым флотом, состоящим из пятнадцати СПГ-танкеров ледового класса $\operatorname{Arc7}$ типа Yamalmax (одиннадцать из них в эксплуатации) [24]. Также проект «Ямал СПГ» в 2019 г. пополнился всесезонным ледокольным танкером «Борис Соколов» для перевозки газового конденсата из порта Сабетта. Информация о танкерах проекта «Ямал СПГ» представлена в табл. 4 (составлена авторами). 
Практически весь газ первых трех линий проекта «Ямал СПГ» (порядка 98,1 \%) законтрактован (сроком до сорока лет) еще в сентябре 2014 г., при этом $86 \%$ пойдет в страны АТР. Поставки будут осуществляться на условиях free-on-board в пункте перевалки в Западной Европе для дальнейшей отправки на рынки стран АТР. Операторы проекта: Total Gas \& Power Limited (британское подразделение Total) - 4 млн т, China National Petroleum Corporation (CNPC) - 3,0 млн т, Gazprom Marketing \& Trading Limited (GM\&T) - 3 млн т, Novatek Gas and Power Asia Pte. Ltd. - 2,86 млн т, Gas Natural Fenosa (Испания) - 2,5 млн т ежегодно. Около 5 \% проекта «Ямал СПГ» зарезервировано для продажи на спотовом рынке.

Отгрузка первого танкера проекта «Ямал СПГ» состоялась в декабре 2017 г. Первые партии СПГ отправлялись западным маршрутом с перегрузкой на конвенционные танкеры на европейских терминалах с последующей доставкой потребителям. В июне 2018 г. произведена отгрузка первой партии СПГ по долгосрочному контракту компании Gas Natural Fenosa (западный маршрут), поставки восточным маршрутом по китайскому долгосрочному контракту (с CNPC) произведены в июле 2018 г. Поставки СПГ по СМП составили 19 дней по сравнению с 35 днями по традиционному маршруту через Суэцкий канал и Малаккский пролив, что позволило сократить время доставки и, соответственно, транспортные затраты. При этом ледовая часть СМП была преодолена за девять дней. В 2018 г. реализовано более 4,0 млн т, продано 57 танкерных партий.

Таблица 4

Газовый флот проекта «Ямал СПГ»

\begin{tabular}{|c|c|c|c|c|}
\hline № & Судно & Флаг & Статус в проекте & Судоходная компания \\
\hline 1 & 2 & 3 & 4 & 5 \\
\hline 1. & $\begin{array}{l}\text { «Кристоф де } \\
\text { Маржери» }\end{array}$ & Кипр & $\begin{array}{l}\text { В эксплуатации с } \\
\text { декабря } 2017 \text { г. }\end{array}$ & ПАО «Совкомфлот» \\
\hline 2. & «Эдуард Толль» & Багамы & $\begin{array}{l}\text { В эксплуатации с } \\
2018 \text { г. }\end{array}$ & $\begin{array}{l}\text { Teekay (Канада) с дочерней } \\
\text { China LNG Shipping } \\
\text { (holdings) Limited (China } \\
\text { LNG) }\end{array}$ \\
\hline 3. & $\begin{array}{l}\text { «Рудольф } \\
\text { Самойлович» }\end{array}$ & То же & То же & То же \\
\hline 4. & «Николай Евгенов» & $\gg$ & \begin{tabular}{|l} 
Запуск в \\
эксплуатацию
\end{tabular} & $\gg$ \\
\hline 5. & «८Владимир Воронин» & $\gg$ & $\begin{array}{l}\text { Начало } \\
\text { эксплуатации - } \\
\text { август } 2019 \text { г. }\end{array}$ & $\gg$ \\
\hline 6. & «Георгий Ушаков» & $\gg$ & $\begin{array}{l}\text { Начало } \\
\text { эксплуатации - } \\
\text { октябрь 2019 г. } \\
\end{array}$ & $\gg$ \\
\hline 7. & «Яков Гаккель» & $\gg$ & $\begin{array}{l}\text { Начало эксплуатации } \\
\text { - ноябрь } 2019 \text { г. }\end{array}$ & " \\
\hline 8. & «Влладимир Визе» & Гонконг & $\begin{array}{l}\text { В эксплуатации } \\
\text { с } 2018 \text { г. }\end{array}$ & $\begin{array}{l}\text { MOL (Япония) (Mitsui O. S. } \\
\text { K. Lines Ltd.) при участии } \\
\text { China Shipping Development }\end{array}$ \\
\hline
\end{tabular}


Окончание таблиц̧ы 4

\begin{tabular}{|c|c|c|c|c|}
\hline 1 & 2 & 3 & 4 & 5 \\
\hline 9. & «Владимир Русанов» & Россия & То же & То же \\
\hline 10. & «Николай Урванцев» & Гонконг & $\begin{array}{l}\text { Начало } \\
\text { эксплуатации - } \\
\text { ноябрь } 2019 \text { г. }\end{array}$ & $\gg$ \\
\hline 11. & «Борис Вилькицкий»" & Кипр & $\begin{array}{l}\text { В эксплуатации } \\
\text { с } 2018 \text { г. }\end{array}$ & $\begin{array}{l}\text { Dynagas (Греция) Ltd. (49 \% } \\
\text { совместно (по 25,5 \%) с ки- } \\
\text { тайскими судоходными } \\
\text { компаниями Sinotrans и } \\
\text { China LNG Shipping }\end{array}$ \\
\hline 12. & «Федор Литке» & То же & То же & То же \\
\hline 13. & «Георгий Брусилов» & $»$ & $\gg$ & $\gg$ \\
\hline 14. & «Николай Зубов» & $»$ & $\gg$ & $\gg$ \\
\hline 15. & «Борис Давыдов» & $\gg$ & $\gg$ & $\gg$ \\
\hline 16. & «Борис Соколов» & $\gg$ & $\begin{array}{l}\text { Запуск в } \\
\text { эксплуатацию }\end{array}$ & $\begin{array}{l}\text { Dynacom Tankers } \\
\text { Management Ltd. (Греция) }\end{array}$ \\
\hline
\end{tabular}

${ }^{*}$ Весной 2018 г. газовоз «Борис Вилькицкий» был понижен до класса Arc4 из-за отказа кормовых двигателей и рулевой колонки.

В первом полугодии 2019 г. все три линии проекта «Ямал СПГ» функционировали выше проектной мощности (было произведено 9,0 млн т СПГ и 0,6 млн т стабильного газового конденсата), отгружено 126 танкерных партий. При этом основная партия СПГ доставлялась на рынки с использованием перевалки с арктических газовозов на конвенционные суда, организованной в Норвегии. С начала перевалочных операций (ноябрь 2018 г.) было выполнено 123 перегрузки борт - борт.

В районе СМП идет разработка еще одного крупного инфраструктурного проекта в сфере производства и транспортировки СПГ - «Арктик СПГ 2»с производственной мощностью около 19,8 млн т в год, ориентированного в первую очередь на активно развивающийся азиатский рынок. Проект «Арктик СПГ 2» будет реализован на базе месторождения Утреннее (Ямал). Пуск первой линии запланирован на 2023 г. с поэтапным вводом объекта в 2023-2025 гг. Участниками «Арктик СПГ 2» являются: ПАО «Новатэк» (60 \%), Total (10\%), CNOOC (10 \%), CNPC (10 \%) и Japan Arctic LNG (10 \%). На решение внешних инвесторов войти в состав партнёров проекта повлияло прежде всего снятие Правительством Российской Федерации запрета использовать суда под иностранным флагом для реализации проектов по производству СПГ. Распоряжением Правительства Российской Федерации № 435-р от 14 марта 2019 г. до 30 декабря 2043 г. разрешено использовать суда, договоры фрахтования которых заключены на срок не менее пятнадцати лет для перевозок природного газа (в т. ч. СПГ) и газового конденсата из порта Сабетта в перевалочные узлы или порты за пределами СМП. До 30 декабря 2021 г. разрешено использовать суда, зафрахтованные на шесть месяцев, в порту Сабетта. Снятие запрета использовать суда под иностранным флагом позволило также устранить юридическое препятствие по организации перевалки СПГ борт - борт в районе Мурманска. До последнего момента существующие поправки к Кодексу торгового мореплавания (2017 г.) позволяли осуществлять каботажные перевозки по СМП 
только судами под российским флагом. Несмотря на то что организация перевалки в районе Мурманска намного дешевле, не требует никакой специальной береговой инфраструктуры, операции по перевалке СПГ осуществляются у побережья Норвегии, в районе Хоннингсвога. Перенос точки перевалки СПГ в район острова Кильдин был запланирован на 25 октября 2019 г.

В рамках проекта «Арктик СПГ 2» в акватории Кольского залива в поселке Белокаменка началось возведение инфраструктурных объектов Центра строительства крупнотоннажных морских сооружений (ЦСКМС). На базе ЦСКМС на намывных площадях Кольского залива строится специализированная верфь для производства уникальных образцов морской техники железобетонных оснований гравитационного типа (ОГТ) для размещения линий сжижения природного газа (по 6,6 млн т на каждой платформе) и других морских буровых и добычных объектов для реализации проекта «Арктик СПГ 2» по экономическому освоению месторождений Гыданской нефтегазоносной области. В районе бухты Уры планируется возвести перевалочный комплекс СПГ мощностью до 20 млн т, что позволит повысить эффективность доставки СПГ в страны Европы как с действующего завода «Ямал СПГ», так и с планируемого «Арктик СПГ 2». С этой целью предполагается установить два суднагазохранилища объемом 360 м³. В перегрузочный комплекс в Ура-губе по СМП СПГ будет доставляться танкерами-газовозами ледового класса Arc7, затем он будет вывозиться потребителям обычными танкерами-газовозами. Аналогичный перевалочный терминал для СПГ в раках проекта «Арктик СПГ 2» планируется построить на восточном побережье Камчатки, в бухте Бечевинской. Строительство перевалочных терминалов в Ура-Губе и бухте Бечевинской позволит оптимизировать транспортную логистику при доставке СПГ потребителям - в страны Европы по западному маршруту СМП через перевалочный комплекс в Ура-Губе, в страны АТР по восточному маршруту. Продажа СПГ с перевалочных терминалов позволит обеспечить гибкость поставок природного газа на мировые рынки, максимально использовать потенциал по созданию СПГ-хабов в АТР и Атлантическом бассейне.

Реализация представленных проектов направлена на диверсификацию направлений и средств транспортировки природного газа, что позволяет использовать ранее недоступные с экономической точки зрения запасы природного газа по причине отсутствия инновационных технологий и технических решений, требующих повышенных капиталовложений и эксплуатационных затрат. Вовлечение в мировой оборот природного газа, разведанного и добытого российскими компаниями на месторождениях в АЗРФ, обеспечивает расширенное воспроизводство запасов природного газа в перспективе и национальную энергетическую безопасность, а также является геополитическим инструментом для укрепления регионального присутствия России в Арктике [32].

\section{4. Экономическая конъюнктура поставок арктического сжиженного природного газа в страны Азиатско-Тихоокеанского региона}

Современный Азиатско-Тихоокеанский рынок (АТР) природного газа имеет довольно сложную структуру. Долгое время ключевыми поставщиками СПГ в данном регионе выступали Австралия и Катар. Однако сланцевая 
революция и ряд других технологических достижений позволили США и России увеличить объемы производства СПГ и выйти на рынок стран АТР. Уникальность данной ситуации заключается в том, что еще десять лет назад США были ключевым импортером СПГ, основные потребности которого удовлетворялись за счет поставок из Катара. Сейчас же эти страны являются прямыми конкурентами в борьбе за АТР, при этом каждая из них имеет свои конкурентные преимущества. Россия, напротив, в течение нескольких десятилетий остается одним из крупнейших экспортеров природного газа в мире, удовлетворяя в первую очередь потребности стран Европейского союза. Однако стремительно растущий спрос на газ в Японии, Южной Корее и, конечно, Китае побудил отечественные компании, такие как ПАО «Новатэк» и ПАО «Газпром», принимать активное участие в борьбе за столь перспективный рынок сбыта. При этом нужно отметить, что правила игры постоянно меняются, возросший уровень конкуренции позволяет странамимпортерам не заключать долгосрочные контракты на покупку СПГ на годы вперед, как это было еще 5-6 лет назад. В случае необходимости возможно заключение контракта и на разовую поставку; при этом практически все экспортеры отказались от запрета на перепродажу газа третьим лицам. В таких условиях ключевым преимуществом, помимо цены на газ, становятся сроки его поставки.

Затянувшаяся «торговая война» между США и Китаем, даже несмотря на объявленное «перемирие», предполагает необходимость проведения оценки перспектив отечественных компаний в борьбе за Азиатско-Тихоокеанский энергетический рынок. По оценкам специалистов, стремительно растущий рынок СПГ в ближайшие 12-15 лет превзойдет рынок трубопроводного газа [48]. При этом наибольшие темпы роста отмечены на АТР, доля которого в общем объеме мирового потребления СПГ достигает 70-75 \% [65]. Рост экономик Южной Кореи и Китая, а также частичное замещение мирного атома (Японией и Южной Кореей) и угля (Китаем, Южной Кореей и Японией) более чистыми источниками энергии способствуют росту потребления природного газа [67]. При этом непростые отношения между США и Китаем, которые переросли в «торговую войну», привели к взаимному введению $25 \%$ импортных пошлин на большинство товаров. В результате Китай сначала снизил объемы закупок американского СПГ, а затем и вовсе отказался от него. «Торговая война» с переменными успехами продолжалась более года, результатом стало подписание 15 января 2020 г. торгового соглашения, согласно которому в течение двухлетнего периода Китай обязуется закупить американских энергоносителей на сумму 52 млрд долл. США [62]. Для сравнения: по итогам 2017 г., т. е. до начала «торговой войны», объем закупок природного газа и нефти составлял порядка 17-8 млрд долл. США. Логично предположить, что трехкратное увеличение объемов закупок американских энергоносителей может привести к вытеснению с рынка других поставщиков. Поэтому основной целью исследования является определение перспектив реализации отечественных арктических проектов по производству СПГ и его продажи на рынке стран АТР в условиях заключения торгового соглашения между США и Китаем.

Согласно официальным статистическим данным, в странах АзиатскоТихоокеанского региона уголь и нефть являются доминирующими видами 
топлива (рис. 5) [47-49]. При этом, если доля нефти остается неизменной на протяжении уже нескольких лет (28 \%), то доля угля пусть и незначительно, но сокращается с 49 \% в 2017 г. до 48 \% по итогам 2019 г. В борьбе за улучшение экологической ситуации такие страны, как Китай, Япония и Южная Корея, отказываются от использования угля, замещая его природным газом (доля природного газа за три года возросла с 11 до $12 \%$ ) и возобновляемыми источниками энергии (ВИЭ) (рост с 3 до 3,5 \%). При этом рост потребления природного газа в мире по итогам 2019 г. составил около $2 \%$ (более 77 млрд м ${ }^{3}$ в натуральном выражении), что значительно ниже среднего показателя за последние годы. Так, по итогам 2018 г. рост потребления составил более $5 \%$. Основной рост пришелся на Китай (более 23 млрд м $^{3}$ ) и США (более 25 млрд м $^{3}$ ). Кроме того, после трагических событий 2011 г., когда из-за сильнейшего землетрясения и последовавшего за ним цунами произошла серьезная авария на атомной электростанции «Фукусима - 1», ряд стран АТР пересмотрел свое отношение к использованию мирного атома. В результате доля ядерной энергии в общей структуре энергопотребления пусть и незначительно, но сократилась.

Для того чтобы реально оценить перспективы отечественных проектов по реализации арктического СПГ на рынке стран АзиатскоТихоокеанского региона в условиях окончания «торговой войны» между США и Китаем и падения спроса практически на все виды энергоресурсов из-за COVID-19, необходимо рассмотреть ситуацию с каждым из крупнейших потребителей отдельно.

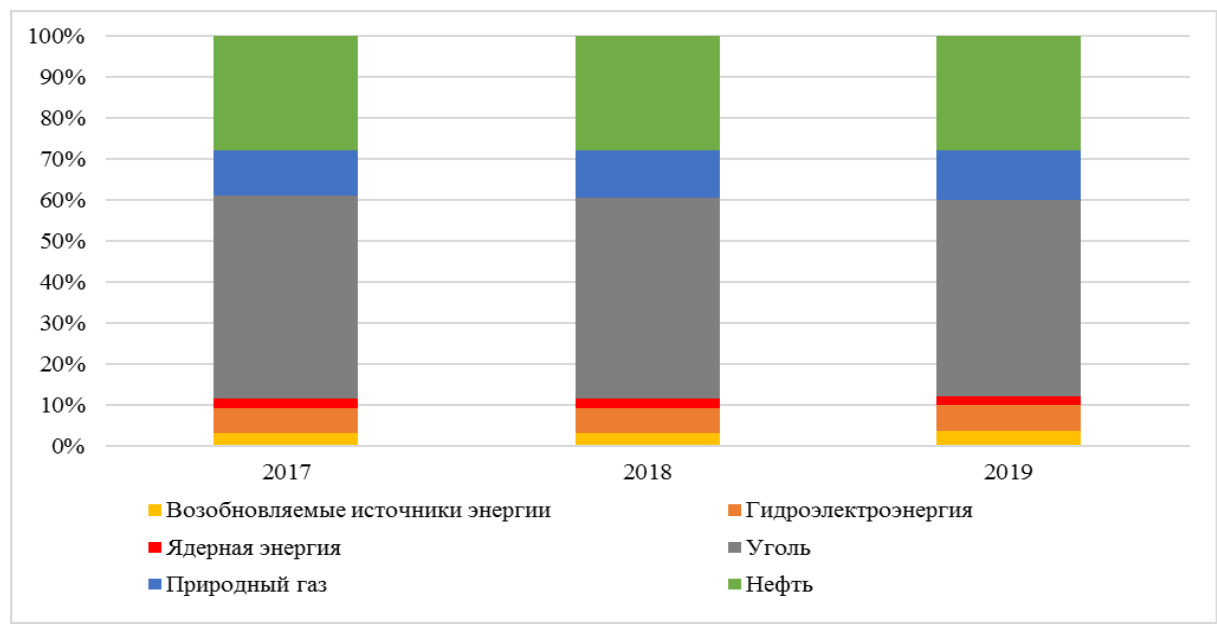

Pис. 5. Потребление топлива странами Азиатско-Тихоокеанского региона [47-49]

По итогам 2019 г. объем потребления природного газа странами Азиатско-Тихоокеанского региона составил $869,9 \mathrm{~m}^{3}$, это на 4,7 \% больше, чем по итогам 2018 г. (рис. 6). Однако начало 2020 г. ознаменовалось сокращением объемов потребления, что обусловлено карантином и частичной остановкой производства. Тем не менее газовый рынок «просел» не так сильно, как нефтяной; отчасти это объясняется тем, что большинство людей было переведено на удаленный режим работы, в результате спрос 
на газ со стороны домохозяйств значительно вырос. Кроме того, из-за падения цен крупные импортеры голубого топлива решили закупиться впрок.

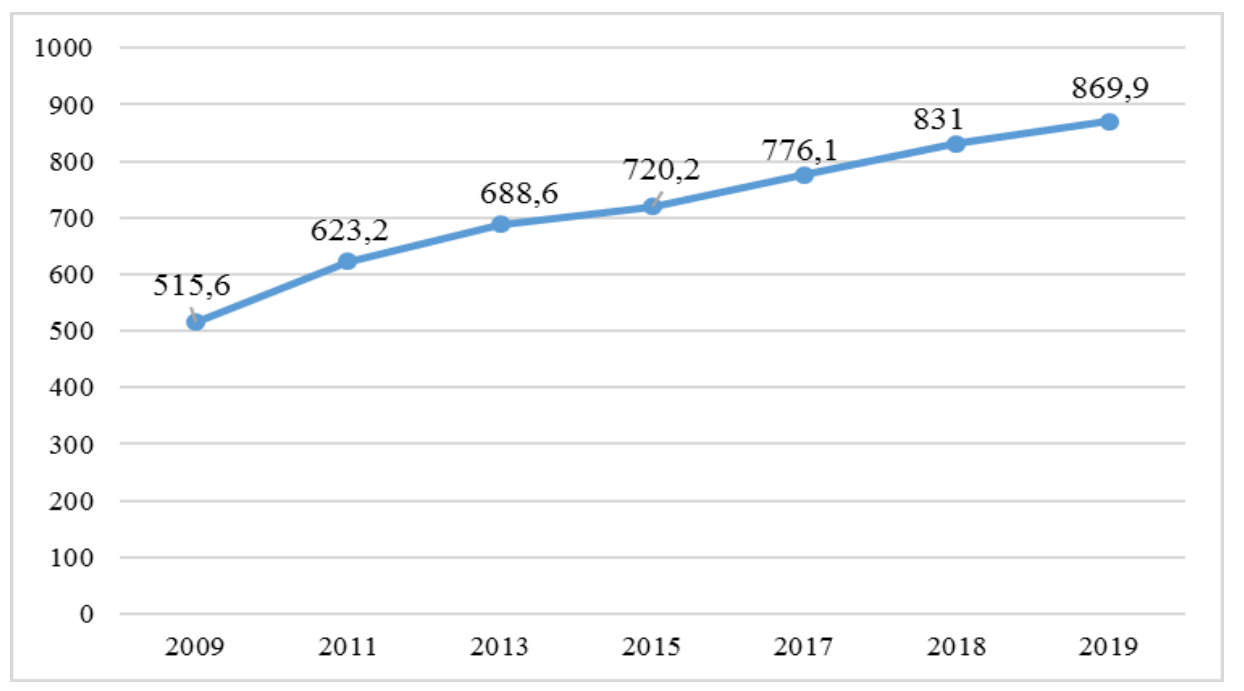

Рис. 6. Потребление природного газа странами Азиатско-Тихоокеанского региона, млрд м ${ }^{3}[41,49]$

Kumaй. По итогам января 2020 г. в связи с вводом карантина и закрытием ряда предприятий потребление газа в стране снизилось на $1 \%$. При этом импорт СПГ по итогам первых двух месяцев снизился более чем на $3 \%$ [49]. В начале февраля компания CNOOC временно приостановила закупку СПГ в рамках контрактов с несколькими компаниями, а в марте аналогичную позицию заняла и компания PETROCHINA. Аналогично развивалась ситуация и с закупками трубопроводного газа - снижение поставок из Узбекистана (на 30-35 \%), Туркменистана (на 15-18 \%) и Казахстана (на $25 \%$ ). С марта началось постепенное восстановление экономики. По предварительным данным, потребление газа в Китае в первом квартале, по сравнению с первым кварталом 2019 г., возросло более чем на 7 \%. Однако этот рост обусловлен увеличением внутренней добычи газа, а рост импорта составил лишь $3 \%$ [33].

Также на две недели по причине проведения профилактических работ (это официальная версия) была приостановлена поставка газа по трубопроводу «Сила Сибири». Однако уже в апреле Китай закупил более 5 млн т СПГ у США (около 6,9 млрд м ${ }^{3}$ ), что на 15 \% превышает показатели марта и на $20 \%$ показатели апреля 2019 г. Такой рост объемов закупок объясняется реализацией торгового соглашения, заключенного между двумя странами в январе этого года. При этом вероятно, что Китай постарается выполнить взятые на себя обязательства, в результате перспективы отечественных компаний по реализации российского СПГ выглядят не столь оптимистичными.

Согласно представленным на рис. 7 данным (составлено автором по официальным данным компании British Petroleum), по итогам 2019 г. Китай импортировал 85 млрд м $^{3}$ СПГ. При этом объем американского 
экспорта СПГ по итогам прошлого года достиг 47,5 млрд м³ [49]. Очевидно, что США не в состоянии на $100 \%$ обеспечить потребности Китая в СПГ, даже несмотря на падение производства и замедление темпов роста потребления энергоресурсов в Поднебесной. При этом по состоянию на середину мая число действующих буровых установок на природный газ в США сократилось до 80, тогда как в 2019 г. их было около 200 [74]. То, что уровень добычи природного газа находится на приемлемом уровне, объясняется попутной добычей газа при добыче нефти, а также инерцией, которая сойдет на нет уже к концу года. Вероятно, что ждать значительного увеличения объемов экспорта американского СПГ в 2020 г. не стоит, а вот перенаправление маршрутов поставок представляется логичным решением. Очевидно, что цены на газ в странах Азиатско-Тихоокеанского региона, в Китае в частности, более привлекательны, чем на европейском рынке [62].

Заключение торгового соглашения между Китаем и США и открытие нового месторождения природного газа (около 1 трлн м³) в провинции Сычуань позволяют предположить, что другим крупным экспортерам СПГ (Австралии, Катару и России) увеличить объемы поставок в ближайшие два года будет сложно. Тем не менее, так как себестоимость российского и катарского природного газа гораздо ниже, чем себестоимость американского, говорить о безоговорочной капитуляции преждевременно. Кроме того, не стоит забывать и о том, что на АТР есть и другие крупные импортеры СПГ, такие как Южная Корея и Япония, объемы импорта СПГ которых сопоставимы с китайскими.

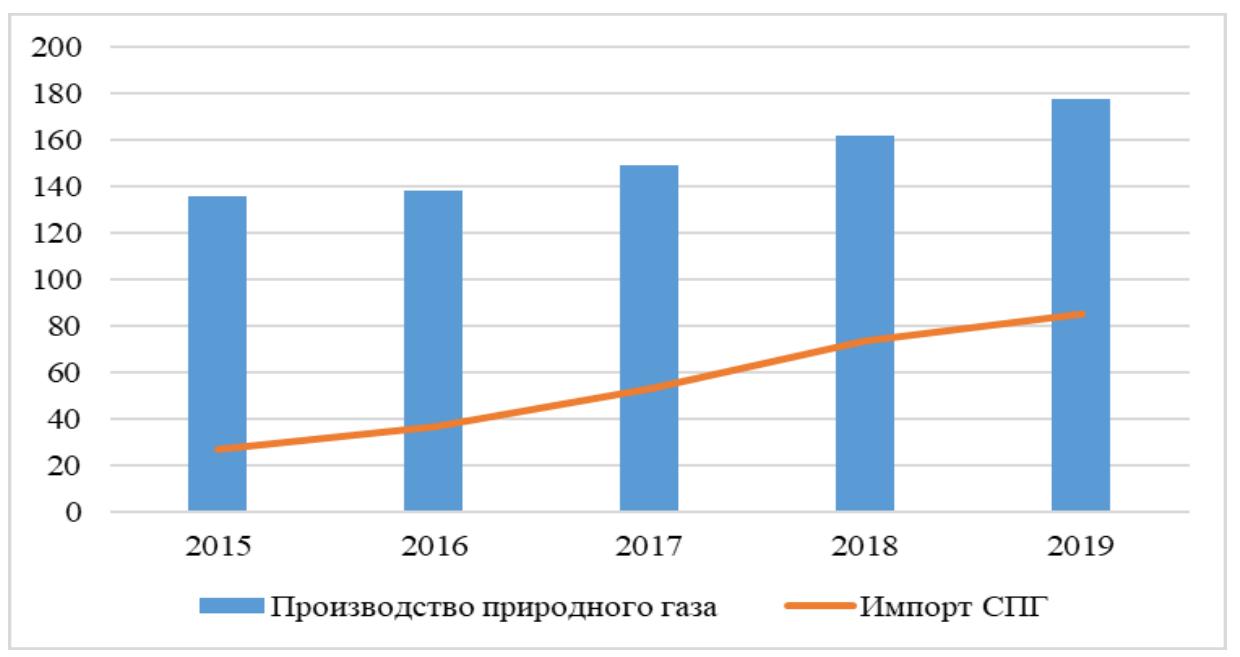

Рис. 7. Объемы производства природного газа в Китае и импорт СПГ, млрд м $^{3}$ [49]

Южнная Корея. Как уже отмечалось, наряду с Китаем и Японией, Южная Корея является крупнейшим импортером и потребителем природного газа в Азиатско-Тихоокеанском регионе. На рис. 8 представлены данные об объемах потребления и импорта СПГ за период 2010-2019 гг. 


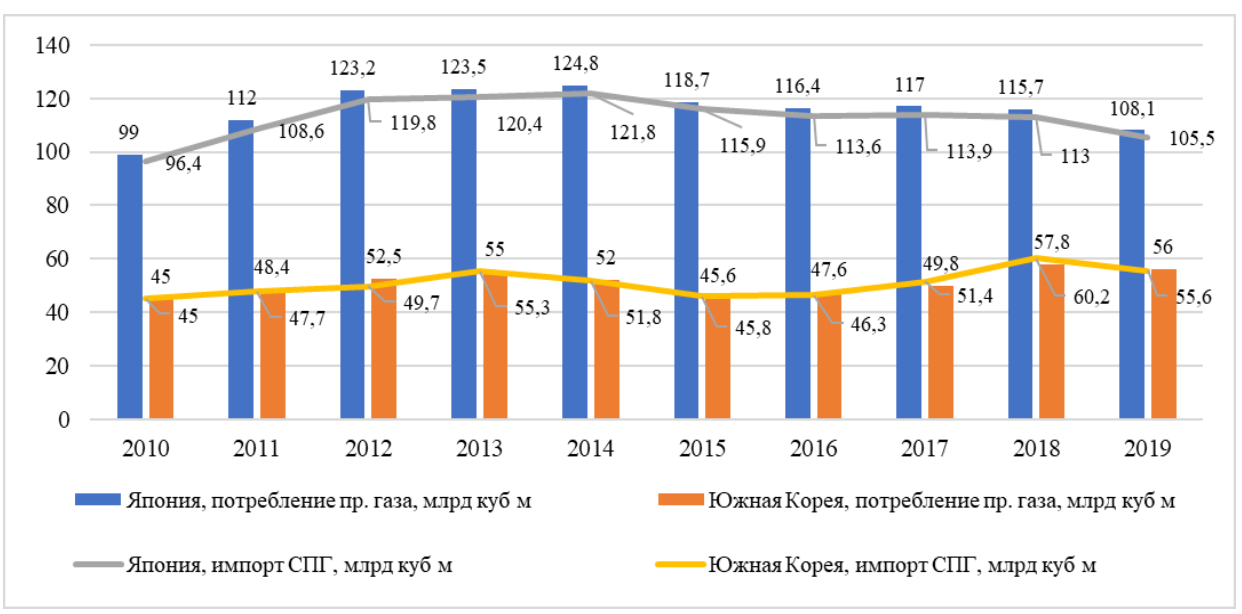

Рис. 8. Потребление и импорт СПГ, млрд м $^{3}[46,48,49,81]$

Несмотря на то что динамика потребления природного газа разнонаправлена, общий объем потребления за десятилетний отрезок вырос почти на $25 \%$. Это объясняется ростом экономики страны, а также стремлением использовать более чистые источники энергии, в первую очередь природный газ. Поскольку в Южной Корее нет значимых доказанных запасов природного газа, почти 100 \% необходимого объема импортируется в виде СПГ. Ключевыми поставщиками выступают Катар, Австралия, Малайзия, Индонезия, Нигерия, Россия и США. Совокупная доля этих стран в общем объеме импортируемого Южной Кореей СПГ равна 100 \%. В этом ряду особо выделяются Катар и Австралия, на долю которых приходится 37 и $21 \%$ от общего объема потребления соответственно.

Что касается Российской Федерации, то ее доля в общем объеме потребления Южной Кореей СПГ составляет $5 \%$, при этом объемы поставок по итогам 2019 г. пусть и незначительно, но выросли - с 2,96 млрд м ${ }^{3}$ по итогам 2018 г. до 3,1 м м $^{3}$ по итогам 2019 г. [49]. Несмотря на столь незначительные объемы поставок, большая часть которых реализуется в рамках проекта «Сахалин-2» [58], перспективы российского СПГ на рынке Южной Кореи более оптимистичны. Это объясняется несколькими причинами.

1. Правительство Южной Кореи прямо заявило о своем желании диверсифицировать маршруты поставок [76] за счет увеличения объемов закупок российского и американского СПГ. При этом возможность увеличения объемов поставок СПГ из США представляется маловероятной из-за снижения числа действующих буровых установок на газ, а также планируемого увеличения объемов поставок американского газа в Китай.

2. Президент Южной Кореи Мун Чжэ Ин после прихода к власти прямо заявил о ставке на ВИЭ и СПГ, а также о постепенном выводе из эксплуатации ядерных мощностей. Так, атомная электростанция «Кори 1», проработавшая почти сорок лет, уже выведена из эксплуатации, а строительство еще шести реакторов было отложено на неопределенный срок [64]. Среди основных причин отказа от АЭС приводится пример 
катастрофы на «Фукусима - 1». При этом, если в непосредственной близости от японской атомной электростанции проживало около 150 тыс. чел., то, например, в радиусе 30 км от Пусанской АЭС проживает более 4 млн человек. С учетом потенциальной угрозы соседства с Северной Кореей, доводы президента страны не выглядят необдуманными и преждевременными.

Важно понимать, что выбывающие мощности (атомных электростанций) довольно легко заменить поставками СПГ. Конкуренция на рынке СПГ возросла - количество поставщиков, как и объемы предложения, увеличиваются, а цены снижаются. При этом Южная Корея на середину 2020 г. обладает пятью терминалами СПГ общей мощностью порядка 118 млрд м ${ }^{3}$, что более чем в два раза превышает объемы импорта по итогам 2019 г. Один терминал СПГ принадлежит частной компании Pohang Iron and Steel Co, остальные - государственные и принадлежат компании Kogas. Согласно данным компании S \& P Global Platts Analytics [49], объем импорта угля в начале 2020 г. сократился более чем на $20 \%$, при этом было закрыто 28 электростанций, работающих на угле (всего их 60). За этот же период объемы импорта СПГ увеличились более чем на $30 \%$. Основная причина снижение цен на СПГ. Так как себестоимость российского СПГ намного ниже, чем австралийского и американского [43, 66, 67], можно говорить о том, что у отечественных компаний появляются реальные перспективы по увеличению объемов продаж СПГ в Южную Корею уже в этом году.

Япония. Согласно данным, представленным на рис. 8, объем потребления СПГ в Японии увеличивался на протяжении четырех лет, с 2011 по 2014 гг. Это связано с трагическими событиями, произошедшими на АЭС «Фукусима-1» 11 марта 2011 г. В результате правительством Японии было принято решение отказаться от использования мирного атома в генерации энергии. С 2011 г. производство электроэнергии на атомных станциях постоянно сокращалось, а в 2014 г. полностью остановилось [77]. Однако с приходом к власти Либерально-демократической партии вопрос, связанный с использованием атомной энергии, снова был пересмотрен. По мнению премьер-министра Японии Синдзо-Абэ, которое он озвучил в начале 2013 г., стране не обойтись без атомных электростанций. Поэтому уже в начале 2015 г. в Японии начался процесс перезапуска атомных реакторов. Кроме того, был составлен план, согласно которому в общем энергобалансе страны не менее 30 \% должно приходиться на долю атомной энергетики.

Перезапуск атомных реакторов, а также увеличение доли энергии, получаемой из возобновляемых источников, позволили Японии сократить объемы потребления (со 124 млрд м ${ }^{3}$ в 2014 г. до 108,1 млрд м ${ }^{3}$ по итогам 2019 г.) и импорта (со 121,8 до 105,5 млрд м³) СПГ [49]. Казалось бы, в такой ситуации говорить о перспективах увеличения объемов поставок российского СПГ в страны АТР, в Японию в частности, неуместно, особенно учитывая непростые отношения между Россией и Японией по разделению спорных (для японской стороны) территорий. Тем не менее Япония видит в России стратегического партнера в вопросах обеспечения энергетической безопасности. В настоящее время Министерством экономики, промышленности и торговли Японии разрабатывается новая энергетическая стратегия, в которой речь идет об обеспечении страны природными 
ресурсами в ближайшие годы. Планируется, что одним из крупнейших поставщиков СПГ должна стать российская компания ПАО «Новатэк».

Несмотря на то что Токио во многих вопросах действует с оглядкой на Вашингтон, вопрос диверсификации поставок СПГ заставил правительство Японии действовать разумно, в результате в июне 2019 г. две японские компании - Jogmeg и Mitsui - стали полноправными участниками проекта «Арктик СПГ 2» с десятипроцентной долей. Стоимость сделки составила более 25 млрд долл. США. Помимо японских компаний свою долю в проекте имеют китайские CNOOC и CNODC, а также французская Total $[80,82]$. Напомним, что в рамках проекта к 2025 г. планируется построить три линии по 6,6 млн т каждая. Строительство первой линии началось в 2019 г., а ввод в эксплуатацию намечен на 2022 г. При этом, по словам Леонида Михельсона, если японский консорциум получит доступ к государственным средствам для реализации зарубежных проектов в рамках новой энергетической стратегии Японии, а ПАО «Новатэк», в свою очередь, достойное предложение, то доля российской компании может сократиться до 50,1 \%. Таким образом, можно говорить о том, что Япония получила доступ к ресурсам энергоносителей в России. При этом нужно учитывать тот факт, что запасы природного газа на месторождении Утреннее, на котором и будет осуществляться добыча, колоссальны и превышают отметку в 1,9 трлн м³.

В разделе проведена оценка перспектив увеличения объемов поставок российского СПГ в страны Азиатско-Тихоокеанского региона. В ходе исследования применялись современные методы, формы и инструменты экономического анализа. Статистические данные за 2010-2019 гг., которые использовались в работе, получены из официальных источников - Росстата, a также из официального бюллетеня компании Total и Статистического обзора мировой энергетики за 2019 год компании British Petroleum.

При проведении оценки было установлено, что ключевыми импортерами СПГ в странах Азиатско-Тихоокеанского региона являются Китай, Южная Корея и Япония (табл. 5). Посредством факторного анализа были определены причины, оказывающие наибольшее влияние на потенциальные возможности увеличения потребностей этих стран в потреблении СПГ: рост экономики, отказ от угля и атомной энергии, стремление диверсифицировать маршруты поставок и самих поставщиков, наличие инфраструктуры для увеличения объемов импорта, возможность увеличения собственной газодобычи. С помощью экономико-математических и статистических методов были определены тенденции развития рынка СПГ в странах Азиатско-Тихоокеанского региона и сделан прогноз возможностей увеличения объемов поставок российского СПГ на горизонте планирования в 4-5 лет.

В виде табличных данных представлены основные показатели, подлежащие сравнению при проведении оценки: общий объем потребления природного газа по итогам 2019 г.; объем импорта СПГ по итогам 2019 г.; потребность в увеличении объемов импорта в ближайшие 4-5 лет; наличие свободных мощностей для импорта и регазификации СПГ на начало 2020 г.; увеличение объемов собственной газодобычи к 2025 г.; планируемые объемы импорта СПГ к 2025 г. 
Таблича 5

Ключевые импортеры СПГ в странах Азиатско-Тихоокеанского региона, выбранные для оценки возможностей увеличения поставок российского СПГ (составлено автором)

\begin{tabular}{|l|c|c|c|}
\hline \multicolumn{1}{|c|}{ Параметр } & Китай & Южная Корея & Япония \\
\hline $\begin{array}{l}\text { Общий объем потребления природного } \\
\text { газа по итогам 2019 г., млрд м }\end{array}$ & 307,3 & 56,0 & 108,1 \\
\hline $\begin{array}{l}\text { Общий объем импорта СПГ по итогам } \\
\text { 2019 г., млрд м }\end{array}$ & 84,8 & 55,6 & 105,5 \\
\hline $\begin{array}{l}\text { Объем импорта российского СПГ по } \\
\text { итогам 2019 г., млрд м }\end{array}$ & 3,4 & 3,1 & 8,7 \\
\hline $\begin{array}{l}\text { Потребность в увеличении объемов } \\
\text { импорта СПГ в ближайшие 4-5 лет }\end{array}$ & Да & Да & Да \\
\hline $\begin{array}{l}\text { Наличие свободных мощностей для } \\
\text { приема и регазификации СПГ на } \\
\text { начало 2020 г., млрд м }\end{array}$ & 25 & 62 & 8 \\
\hline $\begin{array}{l}\text { Увеличение объемов собственной } \\
\text { газодобычи к 2025 г., млрд м }\end{array}$ & Да & Нет & Нет \\
\hline $\begin{array}{l}\text { Планируемые объемы импорта СПГ } \\
\text { к 2025 г., тіп - тах, млрд м }\end{array}$ & $115-125$ & $60-65$ & $110-115$ \\
\hline
\end{tabular}

Анализ показал, что Китай, Южная Корея и Япония к 2025 г. будут нуждаться в дополнительных объемах СПГ. При этом российские компании имеют все шансы для увеличения объемов поставок СПГ.

Полученные результаты представляют собой обобщенную оценку потребностей основных импортеров СПГ в Азиатско-Тихоокеанском регионе. Относительно высокие темпы роста экономики, частичный отказ от атомной энергии, борьба за улучшение экологической ситуации, а также стремление диверсифицировать маршруты поставок объясняют потребности Китая, Южной Кореи и Японии в дополнительных объемах СПГ в ближайшей перспективе. При этом в настоящее время на страны АзиатскоТихоокеанского региона уже приходится около $75 \%$ от общего объема потребления СПГ, производимого в мире.

Проведенная оценка потребностей основных импортеров СПГ показала, что на горизонте планирования в 4-5 лет Китаю, Южной Корее и Японии понадобятся дополнительные объемы СПГ. Так, Япония в стремлении диверсифицировать маршруты поставок, несмотря на все разногласия, существующие между нашими странами, а также явное неодобрение со стороны США, видит в России стратегического партнера, с помощью которого ей удастся повысить свою энергетическую безопасность. Результатом нового сотрудничества стало приобретение японскими компаниями Jogmeg и Mitsui десятипроцентной доли в реализуемом проекте «Арктик СПГ 2». Первые поставки газа в рамках проекта запланированы на 2022 г., а введение в эксплуатацию всех производственных мощностей (19,8 млн т) - на 2025 г. При этом в случае получения достойного предложения ПАО «Новатэк» готово увеличить долю японских компаний до 19,9 \%. 
Южная Корея также заинтересована в диверсификации поставщиков и прямо заявляет о желании увеличить объемы закупок российского и американского СПГ. Однако, учитывая договоренность США с Китаем о значительном увеличении объемов поставок СПГ, а также сокращение числа действующих американских буровых установок на газ, увеличение закупок СПГ у США кажется маловероятным. Основными причинами предполагаемого роста потребления СПГ является отказ от атомной энергии, а также относительно высокие темпы роста экономики.

Китай, в отличие от Японии и Южной Кореи, не делает громких заявлений о необходимости диверсификации поставщиков. Более того, согласно январскому соглашению с США, Поднебесная обязуется закупить только американских энергоресурсов на 52 млрд долл. США за 2020-2021 гг. При этом, памятуя об открытии нового месторождения в провинции Сычуань, доказанные запасы которого составляют около 1 трлн м³, а также о снижении темпов роста потребления природного газа, отмеченном по итогам первого квартала 2020 г. в Китае, можно предположить, что китайская экономика не будет нуждаться в дополнительных объемах СПГ в ближайшие два года. Так как себестоимость СПГ, производимого в Катаре и России намного ниже, чем себестоимость газа, производимого в США, говорить о безоговорочной капитуляции преждевременно. Кроме того, вероятность, что при существующем уровне цен на СПГ американские компании смогут и дальше наращивать или даже просто поддерживать производство на уровне 2019 г., крайне мала. Поэтому, скорее всего, китайская экономика и в ближайшие несколько лет будет являться основным драйвером роста потребления СПГ не только в Азиатско-Тихоокеанском регионе, но и во всем мире.

Также необходимо понимать, что пандемия коронавируса оказывает отрицательное влияние на промышленное производство и экономическое развитие всех стран в целом. Тем не менее определить степень этого влияния на данный момент не представляется возможным.

Таким образом, можно сделать вывод о том, что Российская Федерация обладает необходимой для поддержания объемов добычи и экспорта углеводородных ресурсов инфраструктурой. Однако для наращивания объемов производства арктических нефти и СПГ необходимы значительные денежные средства и современные технологии, привлечение которых затруднено из-за введения санкций в отношении нефтегазового и банковского секторов экономики. 


\section{ГЛава 2. ОСНОВНЫЕ НАПРАВЛЕНИЯ ИНВЕСТИЦИОННОЙ ПОЛИТИКИ В НЕФТЕГАЗОВОЙ ОТРАСЛИ}

\section{1. Экономическая сущность инвестиционной политики}

В управлении экономическими системами инвестиции, т. е. эффективное вложение капитала с целью его приумножения, занимают центральное место. Широкое распространение в отечественной науке понятие «инвестиции» получило в связи с развитием рыночных отношений и появлением научных работ зарубежных авторов.

В Федеральном законе от 25 февраля 1999 г. № 39-Ф3 (ред. от 28 декабря 2013 г.) «Об инвестиционной деятельности в Российской Федерации, осуществляемой в форме капитальных вложений» дается следующее определение: «Инвестиции - это денежные средства, ценные бумаги, иное имущество, в том числе имущественные права, иные права, имеющие денежную оценку, вкладываемые в объекты предпринимательской и (или) иной деятельности в целях получения прибыли и (или) достижения иного полезного эффекта».

На наш взгляд, основные характеристики экономической сущности инвестиций следующие: 1) инвестиции являются объектом экономического управления, поскольку их сущность напрямую связана с экономической сферой ее проявления; 2) сущность инвестиций связана с таким понятием, как капитал, под которым понимаются любые ресурсы, созданные и используемые для производства благ, поэтому инвестиции являются самой активной формой вовлечения капитала в экономический процесс, при этом капитал используется во всех альтернативных его формах; 3) инвестиции всегда осуществляются с конкретной целью, которой является достижение заранее предопределенного результата, носящего как экономический (положительная величина прибыли и т. д.), так и неэкономический характер (например, социальный, экологический и др.); 4) инвестиции связаны с фактором времени, т. е. возможно отказаться от потребления сегодня в пользу будущих благ; 5) инвестиции всегда связаны с фактором риска, так как инвестор, осуществляя вложения, всегда осмысленно идет на риск, связанный с возможным неполучением ожидаемого инвестиционного дохода или вовсе с потерей вложенного капитала.

Исходя из указанных выше характеристик, сформулируем определение понятия «инвестиции» таким образом: инвестиции - это вложение капитала в различные сферы и отрасли экономики, в различные виды деятельности с целью получения прибыли, а также достижения иного экономического или неэкономического результата, осуществление которого основано на рыночных принципах и связано с факторами времени и риска.

Инвестиции, как известно, осуществляются в различных формах. В целях эффективности организации учета и анализа была предпринята попытка обобщить все критерии, по которым можно их классифицировать.

Наиболее существенными признаками инвестиций являются: 1) осуществление вложений лицами (инвесторами), которые имеют собственные цели, не всегда совпадающие с общеэкономической выгодой; 2) потенциальная способность инвестиций приносить доход; 
3) определенный срок вложения средств; 4) целенаправленный характер вложения капитала в объекты и инструменты инвестирования; 5) использование разных инвестиционных ресурсов, характеризующихся спросом, предложением и ценой, в процессе осуществления инвестиций; 6) наличие риска вложения капитала.

Инвестиции предприятия осуществляются в различных формах. В целях систематизации анализа и планирования инвестиций они могут быть сгруппированы по определенным классификационным признакам (табл. 6).

Таблий 6

Классификация инвестиций

\begin{tabular}{|c|c|c|}
\hline $\begin{array}{c}\text { Классификацион- } \\
\text { ный признак }\end{array}$ & Вид инвестиции & Характеристика \\
\hline 1 & 2 & 3 \\
\hline \multirow[t]{2}{*}{$\begin{array}{l}\text { По объектам } \\
\text { вложения средств }\end{array}$} & $\begin{array}{l}\text { Реальные } \\
\text { (капитало- } \\
\text { образующие) }\end{array}$ & $\begin{array}{l}\text { Совокупность вложений в реальные } \\
\text { экономические активы: материальные } \\
\text { ресурсы и нематериальные активы; } \\
\text { вложения капитала в воспроизводство } \\
\text { основных средств, прирост запасов } \\
\text { товарно-материальных ценностей с целью } \\
\text { улучшения операционной деятельности } \\
\text { предприятия и условий труда }\end{array}$ \\
\hline & Финансовые & $\begin{array}{l}\text { Вложения средств в различные } \\
\text { финансовые активы (ценные бумаги, паи, } \\
\text { банковские депозиты и т. п.) }\end{array}$ \\
\hline \multirow[t]{2}{*}{$\begin{array}{l}\text { По цели } \\
\text { инвестирования }\end{array}$} & Прямые & $\begin{array}{l}\text { Вложения в уставный капитал } \\
\text { предприятия с целью установления } \\
\text { непосредственного контроля и управления } \\
\text { объектом инвестирования }\end{array}$ \\
\hline & \begin{tabular}{|l|} 
Портфельные \\
(непрямые)
\end{tabular} & $\begin{array}{l}\text { Средства, вложенные в экономические } \\
\text { активы с целью извлечения дохода и } \\
\text { диверсификации рисков }\end{array}$ \\
\hline \multirow[t]{2}{*}{$\begin{array}{l}\text { По способу учета } \\
\text { инвестируемых } \\
\text { средств }\end{array}$} & Валовые & $\begin{array}{l}\text { Совокупный объем инвестиций, } \\
\text { направленных на приобретение средств } \\
\text { производства, новое строительство, } \\
\text { прирост товарно-материальных запасов в } \\
\text { течение определенного периода }\end{array}$ \\
\hline & Чистые & $\begin{array}{l}\text { Общий объем валовых инвестиций, } \\
\text { уменышенный на сумму амортизационных } \\
\text { отчислений }\end{array}$ \\
\hline \multirow{3}{*}{$\begin{array}{l}\text { По срокам } \\
\text { вложений }\end{array}$} & Краткосрочные & Вложения средств на период до одного года \\
\hline & Среднесрочные & $\begin{array}{l}\text { Вложения средств на срок от одного года } \\
\text { до трех лет }\end{array}$ \\
\hline & Долгосрочные & Вложения средств на срок свыше трех лет \\
\hline
\end{tabular}


Окончание таблицы 6

\begin{tabular}{|c|c|c|}
\hline 1 & 2 & 3 \\
\hline \multirow[t]{4}{*}{$\begin{array}{l}\text { По формам } \\
\text { собственности }\end{array}$} & Частные & $\begin{array}{l}\text { Вложения средств граждан и предприятий } \\
\text { негосударственной формы собственности }\end{array}$ \\
\hline & $\begin{array}{l}\text { Государственны } \\
\text { е }\end{array}$ & $\begin{array}{l}\text { Вложения, осуществляемые } \\
\text { предприятиями государственной формы } \\
\text { собственности, государственными } \\
\text { органами власти и управления }\end{array}$ \\
\hline & Иностранные & $\begin{array}{l}\text { Вложения средств иностранных граждан, } \\
\text { организаций, государств }\end{array}$ \\
\hline & $\begin{array}{l}\text { Совместные } \\
\text { (смешанные) }\end{array}$ & $\begin{array}{l}\text { Вложения, осуществляемые } \\
\text { отечественными и зарубежными } \\
\text { экономическими субъъктами }\end{array}$ \\
\hline \multirow[t]{2}{*}{$\begin{array}{l}\text { По региональному } \\
\text { признаку }\end{array}$} & $\begin{array}{l}\text { Внутренние } \\
\text { (национальные) }\end{array}$ & $\begin{array}{l}\text { Вложения средств в объекты } \\
\text { инвестирования внутри данной страны }\end{array}$ \\
\hline & Зарубежные & $\begin{array}{l}\text { Вложения средств в объекты } \\
\text { инвестирования, размещенные вне } \\
\text { территориальных пределов данной страны }\end{array}$ \\
\hline \multirow[t]{3}{*}{$\begin{array}{l}\text { По уровню } \\
\text { инвестиционного } \\
\text { риска }\end{array}$} & Агрессивные & $\begin{array}{l}\text { Характеризуются высокой прибыльностью } \\
\text { и низкой ликвидностью, высокой степенью } \\
\text { риска }\end{array}$ \\
\hline & Умеренные & $\begin{array}{l}\text { Характеризуются средней степенью риска } \\
\text { при достаточной прибыльности и } \\
\text { ликвидности вложений }\end{array}$ \\
\hline & $\begin{array}{l}\text { Консервативны } \\
\text { е }\end{array}$ & $\begin{array}{l}\text { Вложения пониженного риска, } \\
\text { характеризующиеся надежностью и } \\
\text { ликвидностью }\end{array}$ \\
\hline \multirow[t]{5}{*}{$\begin{array}{l}\text { По форме } \\
\text { капитальных } \\
\text { вложений }\end{array}$} & $\begin{array}{l}\text { Оборонительны } \\
\text { е }\end{array}$ & $\begin{array}{l}\text { Направлены на снижение рисков, } \\
\text { удержание уровня цен, защиту от } \\
\text { конкурентов }\end{array}$ \\
\hline & $\begin{array}{l}\text { Наступательны } \\
\text { е }\end{array}$ & $\begin{array}{l}\text { Обусловлены поиском новых технологий } \\
\text { и разработок в целях поддержания } \\
\text { высокого научно-технического уровня } \\
\text { производимой продукции }\end{array}$ \\
\hline & Социальные & $\begin{array}{l}\text { Инвестиции, целью которых является } \\
\text { улучшение условий труда персонала }\end{array}$ \\
\hline & Обязательные & $\begin{array}{l}\text { Инвестиции, связанные с удовлетворением } \\
\text { государственных требований в части } \\
\text { экологических стандартов, безопасности } \\
\text { продукции, иных условий деятельности }\end{array}$ \\
\hline & $\begin{array}{l}\text { Представитель- } \\
\text { ские }\end{array}$ & $\begin{array}{l}\text { Нацелены на поддержание престижа } \\
\text { предприятия }\end{array}$ \\
\hline
\end{tabular}

Движение инвестиций осуществляется посредством инвестиционной деятельности предприятия. 
В современном экономическом словаре инвестиционная деятельность рассматривается в двух аспектах. В узком определении она представляет собой процесс преобразования инвестиционных ресурсов во вложения, в широком определении - это деятельность, связанная с вложением средств в объекты инвестирования в целях приращения капитальной стоимости. Требованиям воспроизводственного подхода отвечает лишь широкая трактовка инвестиционной деятельности, в соответствии с которой осуществляются: преобразование инвестиционных ресурсов в инвестиционные вложения, т. е. процесс трансформации ресурсов в конкретные объекты инвестиционной деятельности; превращение вложенных средств в прирост капитальной стоимости, окупаемость осуществленных затрат и получение дохода в результате использования инвестиций.

Объекты инвестиционной деятельности - вновь создаваемые и модернизируемые фонды и оборотные средства во всех отраслях и сферах экономики, ценные бумаги, целевые денежные вклады, научно-техническая продукция, другие объекты собственности, а также имущественные права и права на интеллектуальную собственность.

Основными субъектами инвестиций и инвестиционной деятельности выступают инвесторы и пользователи объектов инвестирования.

Инвесторы - группы физических и юридических лиц, которые вкладывают различные ресурсы, включая деньги, в покупку уже существующих или в создание инвестиционных активов рынка (ценные бумаги, доли в компаниях, недвижимость и т. д.) с целью получения прибыли.

Инвестиционная деятельность предполагает наличие риска, под которым понимается возможность возникновения различного рода условий, которые приведут к негативным последствиям для всех или отдельных участников данной деятельности. Формы проявлений негативных последствий различны: потери продукции, повышение текущих и единовременных затрат, а в конечном счете потеря прибыли и снижение эффективности.

Для осуществления инвестиционной деятельности предприятия разрабатывают инвестиционную политику, которая является частью стратегии развития предприятия и общей политики управления прибылью. Она заключается в выборе и реализации наиболее эффективных форм вложения капитала с целью расширения объема операционной деятельности и формирования инвестиционной прибыли.

Инвестиционная деятельность на предприятиях нефтегазовой отрасли представляет собой совокупность управленческих и предпринимательских действий по использованию инвестиций, управлению предприятиями в сфере обеспечения их ресурсами, способствующими увеличению производственного и коммерческого потенциалов в результате реализации целесообразных инвестиционных проектов и программ. На сегодняшний день инвестиционная деятельность является главной формой реализации экономической стратегии, способствующей успешному решению задач, стоящих как перед каждым из предприятий, так и перед страной в целом. 
Инвестиционная деятельность предприятия нефтегазовой отрасли подчинена долгосрочным целям его развития, поэтому она должна осуществляться в соответствии с разработанной инвестиционной политикой, которая представляет собой совокупность обязательных к соблюдению общих положений, принципов и методических подходов в сфере управления инвестициями, а также является частью общей финансовой стратегии предприятия.

По мнению И. А. Бланка, инвестиционная политика предприятия заключается в выборе и реализации наиболее эффективных форм реальных и финансовых инвестиций предприятия с целью обеспечения высоких темпов его развития и постоянного возрастания его рыночной стоимости.

Инвестиционная политика является важной составляющей общей экономической политики предприятия, она выступает как один из главных факторов обеспечения эффективного развития и роста его стоимости в соответствии с избранной им экономической политикой. Вместе с тем по отношению к последней инвестиционная политика носит подчиненный характер, что определяет необходимость учета приоритетности целей экономической политики при ее формировании.

Основной целью инвестиционной политики является достижение максимального финансово-экономического эффекта от оптимизации интересов различных экономических субъектов, участвующих в инвестиционном процессе.

Кроме того, ее разработка может предусматривать ряд специфических целей: 1) создание условий для эффективного размещения инвестиционных ресурсов, прироста инвестируемого капитала и максимизации инвестиционной прибыли; 2) обеспечение минимизации инвестиционных рисков; 3) обеспечение ликвидности инвестиций; 4) достижение экономического, научно-технического, экологического и социального эффектов от инвестиционной деятельности.

В процессе реализации основной цели инвестиционной политики предприятия решаются следующие задачи:

- повышение темпов экономического развития предприятия за счет эффективной инвестиционной деятельности;

- получение максимума чистой прибыли на вложенный капитал при минимальных инвестиционных затратах;

- защита от инвестиционных рисков, связанных с реализацией инвестиционных проектов;

- учет ликвидности инвестиций (необходимо анализировать вероятность существенных изменений внешней инвестиционной среды, конъюнктуры рынка и политики развития предприятия в предстоящем периоде, способных снизить доходность отдельных объектов инвестирования, повысить уровень рисков и таким образом оказать негативное влияние на общую инвестиционную привлекательность предприятия);

- ускорение реализации инвестиционных программ и проектов;

- обеспечение финансовой устойчивости и платежеспособности предприятия в процессе осуществления инвестиционной деятельности; 
- эффективное распоряжение средствами на осуществление бесприбыльных инвестиционных проектов.

На этапе формирования и реализации инвестиционной политики важно оценить отраслевой аспект организации процесса и охарактеризовать каждый из этапов с позиции содержания его внутренних процессов. К отраслевым особенностям организации формирования и реализации инвестиционной политики в нефтегазовом секторе экономики можно отнести:

- формирование среднесрочных инвестиционных программ, разрабатываемых с учетом максимально возможного достижения стратегических, производственных и финансовых целей предприятия;

- значительное превалирование реальных инвестиций в общей структуре над финансовыми инвестициями;

- высокий уровень финансовых рисков недополучения и (или) полной утраты дохода и (или) прибыли при реализации инвестиционных проектов и инвестиционной политики в целом в случаях потенциально возможного создания неблагоприятной внешней финансовой среды;

- незначительное влияние внутренних факторов финансовой среды в крупных компаниях нефтегазового сектора на принятие решений по формированию и реализации инвестиционной политики;

- сложность точного прогнозирования баланса спроса и предложения, a также цен на нефтяное сырье в рамках принятия конкретных управленческих решений по отдельным инвестиционным проектам;

- высокая значимость из числа внешних факторов уровня действующего законодательства по налогам и сборам, не обеспечивающего необходимый уровень рентабельности проведения геолого-разведочных работ, промышленного строительства, а также разработки трудно извлекаемых запасов углеводородов.

При разработке инвестиционной политики предприятия целесообразно определять общий объем его инвестиций, способы рационального использования накоплений, включая возможные комбинации различных источников финансирования и привлечения заемных средств, a также соблюдать соотношение намечаемых предприятием источников финансирования инвестиций и направлений их использования по объемам и структуре, обеспечивающее сохранение финансовой устойчивости предприятия.

Выбор инвестиционной политики во многом зависит от инвестиционных предпочтений предприятия-инвестора. В соответствии с этими предпочтениями выделяют следующие виды инвестиционной политики: консервативная, компромиссная (умеренная) или агрессивная.

Консервативная инвестиционная политика — вариант политики инвестиционной деятельности предприятия, приоритетной целью которой является минимизация уровня инвестиционного риска. При осуществлении такой политики инвестор не стремится ни к максимизации уровня текущей прибыльности инвестиций, ни к максимизации темпов роста капитала.

Компромиссная (умеренная) инвестиционная политика — вариант политики осуществления инвестиционной деятельности предприятия, направленной на выбор таких объектов инвестирования, по которым уровни 
прибыльности и риска в наибольшей степени приближены к среднерыночным.

Агрессивная инвестиционная политика связанна с ориентацией на максимизацию дохода и представляет собой вариант осуществления инвестиционной деятельности предприятия, направленной на выбор таких объектов инвестирования, по которым уровни прибыльности и риска значительно выше среднерыночных.

Инвестиционную политику предприятия классифицируют в зависимости от её направленности: повышение эффективности производства; модернизация технологического оборудования и технологических процессов; создание новых предприятий (производств); внедрение принципиально нового оборудования и выход на новые рынки сбыта.

Разработка общей инвестиционной политики предприятия осуществляется по следующим направлениям.

Первый этап - исследование и учет условий внешней инвестиционной среды и конъюнктуры инвестиционного рынка. На этом этапе проводится анализ инвестиционного климата, текущей и прогнозной конъюнктуры инвестиционного рынка и определяющих ее факторов, что базируется на выявлении тенденций, закономерностей развития инвестиционного рынка России в целом и по отдельным формам инвестирования.

Второй этап - анализ результатов инвестирования предприятия в предшествующем периоде, что позволяет оценить фактический уровень его инвестиционной активности и степень завершенности начатых ранее инвестиционных программ и проектов. Анализ включает: 1) оценку динамики общего объема инвестирования капитала в прирост реальных активов, определение удельного веса реального и финансового инвестирования в общем объеме инвестиций компании; 2) определение степени реализации отдельных инвестиционных проектов и программ, оценку уровня освоения инвестиционных ресурсов, предусмотренных на эти цели, в разрезе объектов реального и финансового инвестирования; 3) оценку уровня завершенности начатых ранее инвестиционных проектов и программ, уточнение необходимого объема инвестиционных ресурсов для полного их завершения.

Третий этап - поиск и выбор объектов инвестирования. Выбор форм инвестиционной деятельности предприятия зависит от стратегии его экономического и финансового развития. На этом этапе определяется соотношение основных форм инвестирования по функциональной, региональной и отраслевой направленности.

Поиск и выбор объектов инвестирования предусматривает: анализ текущего предложения на инвестиционном рынке; отбор инвестиционных проектов и финансовых инструментов, соответствующих формам инвестиционной деятельности компании; подготовку бизнес-планов инвестиционных проектов; экспертизу отобранных объектов инвестирования.

Оиенка инвестииионной привлекательности отдельных объектов инвестирования зависит от многих факторов и носит строго индивидуальный характер. На данном этапе для анализа используются приблизительные, 
укрупненные данные, полученные на основе государственной статистики или иной общедоступной информации. Поэтому до тех пор, пока та или иная концепция инвестиционного проекта не получит принципиального одобрения лиц, ответственных за принятие решений об инвестициях, нецелесообразно тратить дополнительные средства на сбор или подготовку более детальной и достоверной информации.

Отбор инвестииионных проектов и финансовых инструментов, соответствующих формам инвестиционной деятельности компании. Инвестиционный проект включает, как правило, обоснование экономической целесообразности, объема и сроков осуществления капитальных вложений, в том числе необходимую проектно-сметную документацию, разработанную в соответствии с законодательством Российской Федерации и утвержденными в установленном порядке стандартами (нормами и правилами), а также описание практических действий по осуществлению инвестиций (бизнес-план).

При разработке схемы финансирования инвестиционного проекта рассматриваются следующие варианты: полное самофинансирование, акционирование, кредитное финансирование, лизинг, смешанное (долевое) финансирование.

Вложение средств в инвестиционный проект целесообразно, если инвестиционный процесс отвечает следующим критериям: чистая прибыль от данного вложения превышает чистую прибыль от помещения средств на банковский депозит или прибыль от других вложений; рентабельность инвестиций выше уровня инфляции; рентабельность проекта с учетом фактора времени выше рентабельности альтернативных проектов; рентабельность активов компании после осуществления проекта будет не ниже необходимого критического уровня и превысит среднюю расчетную ставку по заемным средствам; данный проект соответствует генеральной стратегической линии предприятия с точки зрения сроков окупаемости вложений, наличия финансовых источников покрытия издержек до начала окупаемости проекта, обеспечения достаточно стабильных поступлений.

Указанные критерии не являются исчерпывающими, их выбор субъективен и зависит от преследуемой цели и сложившихся условий.

Инвестиционный проект требует разработки бизнес-плана. Бизнесплан - основной документ, разрабатываемый и предоставляемый инвестору по реальному инвестиционному проекту. В нем в краткой форме и общепринятой последовательности разделов излагаются основные характеристики проекта и финансовые показатели, связанные с его реализацией. Целью его разработки и представления является мобилизация инвестиционных ресурсов или получение инвестиционного кредита. Он должен обеспечить эффективность намечаемых инвестиций.

Разработка и изложение бизнес-плана подчинены определенной логической структуре, которая носит стандартизированный характер в большинстве стран с развитой рыночной экономикой. Отклонения от этой общепринятой структуры вызываются лишь отраслевыми особенностями и масштабами проекта. Разработка бизнес-плана представляет собой основную фазу предынвестиционных исследований. 
Экспертиза отобранных объектов инвестирования. Оценка эффективности инвестиций предусматривает проведение анализа отобранных объектов инвестирования с позиции их экономической эффективности. Для каждого объекта инвестирования используется определенная методика оценки эффективности, по результатам которой проводится ранжирование инвестиционных проектов и финансовых инструментов по критерию их эффективности. Для реализации принимаются объекты инвестирования, обеспечивающие наибольшую доходность.

Четвертый этап - поиск и выбор источников привлечения инвестиций для развития компании.

Согласно действующему законодательству, инвестиционная деятельность предприятий может финансироваться: 1) за счет собственных финансовых ресурсов и внутрихозяйственных резервов инвестора (прибыли, амортизационных отчислений, накопления, сумм, выплачиваемых страховыми органами в виде возмещения за ущерб от стихийных бедствий и др.); 2) заемных финансовых средств инвестора (банковских и бюджетных кредитов, облигационных займов и других средств); 3) привлеченных финансовых средств инвестора (средств от продажи акций, благотворительных и иных взносов, средств, выделяемых вышестоящими холдинговыми и акционерными компаниями, промышленно-финансовыми группами на безвозмездной основе); 4) ассигнований из федерального, региональных и местных бюджетов, фондов поддержки предпринимательства, предоставляемых на безвозмездной основе; 5) иностранных инвестиций, предоставляемых в форме финансового или иного участия в уставном капитале совместных предприятий, а также в форме прямых вложений (в денежной форме) международных организаций и финансовых институтов, государств, предприятий и организаций различных форм собственности и частных лиц; 6) различных форм заемных средств, в том числе кредитов, предоставляемых государством на возвратной основе, кредитов иностранных инвесторов, облигационных займов, кредитов банков и других институциональных инвесторов (инвестиционных фондов и компаний, страховых обществ, пенсионных фондов), а также векселей и других средств.

При исследовании и разработке эффективной инвестиционной политики предприятия нужно соблюдать следующие правила: 1) разработка инвестиционной политики в соответствии с законодательными и нормативными актами Российской Федерации, нормирующими инвестиционную деятельность; 2) исследование взаимодействий инвестиционных проектов и их действия на все составляющие системы; 3) предоставление возможности выбора при рассмотрении и принятии управленческих решений; 4) выбор таких проектов, которые при прочих равных условиях гарантируют максимальную эффективность инвестиций; 5) обеспечение ликвидности инвестиций; 6) сокращение до минимума инвестиционных рисков; 7) анализ нестабильности инвестиционной политики в зависимости от изменения внешней среды, в связи с этим при понижении рентабельности вовремя принять решение о реинвестировании высвобождаемого капитала и выходе из неэффективного проекта. 
Основными принципами при разработке эффективной инвестиционной политики предприятия являются: правовой принцип (правовая защита инвестиций); принцип независимости и самостоятельности (свобода выбора инвестиционного проекта, его разработки и осуществления); принцип системного подхода; принцип эффективности (выбор такого инвестиционного проекта, который обеспечит наибольшую результативность).

При разработке инвестиционной политики учитываются следующие факторы: финансово-экономическое положение предприятия; технический уровень производства, наличие у него незавершенного строительства и неустановленного оборудования; лизинговые условия (возможность получения оборудования по лизингу); наличие у предприятия как собственных капиталов, так и возможности привлечения заемных средств в форме кредитов и займов; финансовые условия инвестирования на рынке капитала; льготы, получаемые инвестором от государства; коммерческая и бюджетная эффективность намечаемых к реализации инвестиционных проектов; условия страхования и получения гарантий от некоммерческих рисков.

Для реализации инвестиционной политики предприятиями разрабатывается инвестиционная программа, которая представляет собой совокупность реальных инвестиционных проектов, сгруппированных по отраслевым, региональным и привлекательным для инвестиций признакам. Программа представляет собой единый объект управления.

Инвестиционная привлекательность - обобщающая характеристика преимуществ и недостатков отдельных объектов инвестирования с позиций конкретного инвестора по формируемым им критериям.

Сформировав инвестиционную программу и определившись c объектами инвестирования, предприятие может приступить к формированию инвестиционных проектов.

Инвестиционный проект - это объект реального инвестирования, намечаемый к реализации в форме приобретения целостного имущественного комплекса, реконструкции, модернизации, капитального ремонта и т. п.

Правила принятия инвестиционных решений можно сформулировать следующим образом: 1) инвестировать денежные средства в производство или ценные бумаги имеет смысл, только если можно получить чистую прибыль выше, чем от хранения денег в банке; 2) инвестировать средства имеет смысл, только если рентабельность инвестиций превышает темпы роста инфляции; 3) инвестировать имеет смысл только в наиболее рентабельные с учетом дисконтирования проекты.

Таким образом, решение об инвестировании в проект принимается, если он удовлетворяет следующим критериям: дешевизна проекта; минимизация риска инфляционных потерь; краткость срока окупаемости; стабильность или концентрация поступлений; высокая рентабельность как таковая и после дисконтирования; отсутствие более выгодных альтернатив.

На практике выбираются проекты не столько наиболее прибыльные и наименее рискованные, сколько лучше всего вписывающиеся в стратегию фирмы. 
Инвестиционная политика промышленного предприятия нефтегазовой отрасли - важная составляющая его функционирования в целом. Для стабильной конкурентоспособности и устойчивого развития необходимо грамотно управлять инвестициями, а также своевременно принимать решения по отдельным инвестиционным проектам.

\section{2. Экономическая эффективность инвестиций в нефтегазовую отрасль}

$\begin{array}{rrrrr}\text { Наиболее } & \text { важный } & \text { этап в процессе } & \text { принятия инвестиционных } \\ \text { решений }- & \text { оценка } & \text { эффективности реальных инвестиций }\end{array}$ (капиталовложений). Цель инвестиционного анализа состоит в объективной оценке целесообразности осуществления краткосрочных и долгосрочных инвестиций, разработке базовых ориентиров инвестиционной политики предприятия. Здесь следует отметить в первую очередь принятые в 1994 г. в России в соответствии с мировыми стандартами Методические рекомендации по оценке эффективности инвестиционных проектов (издания 1994, 1999 гг.).

Система оценок экономической эффективности инвестиций делится на две группы методов, одна из которых основана на дисконтированных (временных) оценках, а другая - на простых (учтенных) оценках.

Первая группа включает расчеты: чистой приведенной стоимости проекта (net present value - NPV); индекса рентабельности инвестиций (profitability index - PI); внутренней нормы доходности (рентабельности) инвестиций (internal rate of return - IRR); дисконтированного срока окупаемости инвестиций (discounted payback period - DPP).

Вторая группа включает расчеты: срока окупаемости инвестиций (payback period - PP); учетной нормы рентабельности (accounting rate of return - ARR); коэффициента сравнительной экономической эффективности $\left(\mathrm{K}_{\ni}\right)$.

Необходимость использования нескольких методов оценки вызвана тем, что результаты, получаемые с использованием различных методов, могут иметь противоречивый характер. Сравнивая результаты анализа эффективности инвестиций по различным методам, аналитик делает выводы о приемлемости того или иного проекта.

В российской практике для оценки экономической эффективности инвестиционных проектов используется группа методов, основанная на дисконтированных оценках.

1. Чистая текущая стоимость (NPV) - это текущая стоимость чистых денежных потоков по проекту за вычетом первоначальных инвестиций, необходимых для его реализации, рассчитывается как разность дисконтированных денежных потоков доходов и расходов, производимых в процессе реализации инвестиционного проекта за прогнозируемый период, по следующей формуле:

$$
\mathrm{NPV}=\sum_{n=1}^{N}\left(\mathrm{CF}_{n} * \frac{1}{(1+i)^{n}}\right)-\sum_{n=0}^{M}\left(I_{n} * \frac{1}{(1+i)^{n}}\right),
$$

где $\mathrm{CF}_{n}$ - чистый денежный поток по проекту в $n$-м году; $I_{n}-$ сумма первоначальных инвестиций по проекту в $n$-м году; $i$ - ставка 
дисконтирования, характеризующая минимальную требуемую доходность по проекту; $\frac{1}{(1+i)^{n}}$ - коэффициент дисконтирования в $n$-м году.

По своей сути чистая текущая стоимость показывает, сколько денег будет заработано при реализации проекта дополнительно к требуемой доходности. После вычисления принимается решение: если NPV > 0, проект целесообразен, так как денежные доходы по проекту больше суммы предполагаемых расходов; если NPV < 0, проект нецелесообразен, так как денежные расходы по проекту превышают доходы по нему; если NPV $=0$, проект безубыточен (доходы по проекту равны затратам по нему); если решение принимается по ряду альтернативных проектов, побеждает тот из них, который имеет наибольшее значение NPV, если только оно положительное.

2. Индекс рентабельности инвестиций (PI) - это отношение текущей стоимости будущих чистых денежных потоков проекта к первоначальным инвестициям по этому проекту. Данный показатель является следствием выше рассмотренной методики расчета NPV и рассчитывается как отношение чистой текущей стоимости денежного притока к чистой текущей стоимости денежного оттока (включая первоначальные инвестиции) по следующей формуле:

$$
\mathrm{PI}=\sum_{n=1}^{N}\left(\mathrm{CF}_{n} * \frac{1}{(1+i)^{n}}\right) / \sum_{n=0}^{M}\left(I_{n} * \frac{1}{(1+i)^{n}}\right),
$$

где $\mathrm{CF}_{n}$ - чистый денежный доход по проекту в $n$-м году; $I_{n}-$ сумма первоначальных инвестиций по проекту в $n$-м году; $i$ - ставка дисконтирования, характеризующая минимальную требуемую доходность по проекту; $\frac{1}{(1+i)^{n}}$ - коэффициент дисконтирования в $n$-м году.

Условия принятия проекта по данному инвестиционному критерию следующие: если PI $>1$, то проект следует принять; если PI $<1$, то проект следует отвергнуть; если PI = 1 проект ни прибыльный, ни убыточный.

Индекс рентабельности - относительный показатель эффективности инвестиционного проекта, характеризует уровень доходов на единицу затрат, т. е. эффективность вложений. Чем больше значение этого показателя, тем выше отдача денежной единицы, инвестированной в данный проект. Данному показателю следует отдавать предпочтение при комплектовании портфеля инвестиций с целью максимизации суммарного значения NPV.

Несложно заметить, что при оценке проектов, предусматривающих одинаковый объем первоначальных инвестиций, критерий PI полностью согласован с критерием NPV. Таким образом, критерий PI имеет преимущество при необходимости выбора одного проекта из ряда альтернативных, имеющих примерно одинаковые значения NPV, но разные объемы требуемых инвестиций. В данном случае выгоднее тот из них, который обеспечивает большую эффективность вложений.

3. Внутренняя норма доходности, или внутренняя норма рентабельности (IRR), - это такое значение ставки дисконтирования, при котором NPV инвестиционного проекта равно нулю:

$$
\mathrm{IRR}=i, \text { при котором NPV }=\mathrm{NPV}(i)=0 .
$$


Смысл расчета данного коэффициента при анализе эффективности планируемых инвестиций заключается в следующем: IRR показывает максимально допустимый относительный уровень расходов, которые могут быть ассоциированы с данным проектом.

Интерпретация этого показателя состоит в трактовке внутренней нормы доходности как возможной нормы дисконта, при которой проект выгоден по критерию NPV. Решение принимается на основе сравнения IRR c нормативной рентабельностью, при этом чем выше значения внутренней нормы доходности и больше разница между ее значением и выбранной ставкой дисконта, тем больший запас прочности имеет проект. Для расчета IRR с помощью таблиц дисконтирования выбирают два значения коэффициента дисконтирования $i 1<i 2$ таким образом, чтобы в интервале $(i 1, i 2)$ функция $\mathrm{NPV}=\mathrm{NPV}(i)$ меняла свое значение с «+» на «-» или с «-» на «+». Далее применяют формулу:

$$
\mathrm{IRR}=i 1+\frac{\mathrm{NPV}_{(i 1)}}{\mathrm{NPV}_{(i 1)}-\mathrm{NPV}_{(i 2)}} *(i 2-i 1),
$$

где NPV - чистая текущая стоимость инвестиционного проекта; $i 1$ - значение коэффициента дисконтирования, при котором $\mathrm{NPV}(i 1)>0$; $i 2-$ значение коэффициента дисконтирования, при котором NPV $(i 2)<0$.

Точность вычислений обратно пропорциональна длине интервала ( $i 1$, $i 2)$, а наилучшая аппроксимация достигается, когда $i 1$ и $i 2-$ ближайшие друг к другу значения коэффициента дисконтирования, удовлетворяющие сформулированным выше условиям.

4. Дисконтированный срок окупаемости (DPP) - это период, который требуется для того, чтобы дисконтированные, т. е. приведенные к начальному периоду, суммарные денежные поступления от реализации инвестиционного проекта сравнялись с суммой инвестиций по нему:

$$
\mathrm{DPP}=\frac{I_{0}}{\mathrm{PV}^{(s)}}
$$

где $I_{0}-$ величина инвестиционных вложений; $\mathrm{PV}^{(\mathrm{s})}-$ среднегодичный приведенный чистый доход, который рассчитывается как отношение общего показателя суммированной чистой текущей стоимости денежного притока к показателю временного периода реализации инвестиционного проекта:

$$
\mathrm{PV}^{(s)}=\frac{\sum_{n=1}^{N} \mathrm{PV}}{N},
$$

где $\mathrm{PV}=\sum_{n=1}^{N} \mathrm{CF}_{n} * \frac{1}{(1+i)^{n}}-$ показатель суммы дисконтированной чистой текущей стоимости денежного притока за $n$ лет; $N$ - временной период реализации инвестиционного проекта.

Оценка проектов по данному методу позволяет делать более точные выводы по сравнению с использованием простого срока окупаемости. Этот метод учитывает временную стоимость денег. Следовательно, с его помощью можно определить срок, когда инвестору возвращаются его первоначальные вложения с учетом изменения стоимости денег за период возврата инвестиций.

Ни один из перечисленных критериев сам по себе не является достаточным для принятия решения о финансировании проекта. Такое решение должно приниматься с учетом значений всех перечисленных критериев и интересов всех участников инвестиционного проекта. 


\section{3. Организация и функционирование экономических кластеров}

В настоящее время все большее распространение в системе регионального управления получает кластерный подход, который постепенно превращается в эффективный способ взаимодействия компаний, не располагающих возможностью самостоятельно реализовать крупные проекты. Кроме того, они являются важным фактором поддержки малого и среднего бизнеса, способного при условии государственной поддержки быстро адаптироваться к создаваемой структуре регионального кластера. Малые и средние предприятия формируют в структуре кластера конкурентную среду, выполняя роль поставщиков для крупных компаний, составляющих ядро кластера; а те, в свою очередь, делегируют им производство необходимых товаров и услуг, что оказывает положительное влияние на малый и средний бизнес в регионе, способствуя его инновационной ориентации и достижению им более высокого уровня технологии, организации и управления производством [53].

Значительную роль в развитии промышленных кластеров играет кластерная политика, которая, являясь важным элементом стратегии социальноэкономического развития региона, выполняет функцию стимулирования инновационных процессов, аккумулируя и интегрируя в рамках кластера современные достижения науки и техники. Другими словами, если оценке подлежит не конкретно кластерная политика, а кластерный подход в целом, задачей оценки будет демонстрация того, что рост кластера может быть катализатором роста экономики региона.

Одной из немногих фундаментальных работ, посвященной изучению влияния кластеров на развитие регионов, является построение Индекса конкурентоспособности бизнеса (ИКБ), проводимое под руководством М. Портера, который отмечает, что промышленная политика в своем классическом варианте представляет собой востребованную на мировом рынке долю продукции, поэтому центральным фактором экономического развития становится создание условий для быстрого и существенного роста производства. «Уровень жизни в стране определяется производительностью ее экономики, которая измеряется величиной товаров и услуг на единицу человеческих, финансовых и природных ресурсов» [51]. По мнению М. Портера, стабильные правовые, политические, социальные институты и устойчивая макроэкономическая политика являются предпосылками увеличения национального благосостояния.

В то же время конкурентоспособность региона определяется способностью фирм создавать товары и услуги, пользующиеся устойчивым спросом, с помощью эффективных способов производства, распределения и потребления. Только таким образом промышленные экономические кластеры могут обеспечить и поддерживать высокую заработную плату работников компаний и прибыль на капитал, необходимые для привлечения крупных инвестиций.

Производительность кластера однозначно определяется производительностью входящих в его структуру компаний, однако она неразрывно связана с качеством бизнес-среды. Более производительные стратегии компаний требуют более квалифицированной рабочей силы, лучшей 
информированности, более эффективного управления, усовершенствованной инфраструктуры, современной научной базы, более интенсивного конкурентного давления. Компании должны смещаться от конкуренции в затратах или сравнительных преимуществах (дешевая рабочая сила или природные ресурсы) к соперничеству в конкурентных преимуществах, возникающих в инновационной, интеллектуальной и других сферах. В области распределения необходимо шире использовать собственные каналы и сети, быть менее зависимыми от иностранных посредников.

Поэтому разработанный М. Портером ИКБ специально предназначен для оценки макроэкономических факторов, определяющих уровень производительности экономического кластера. Для характеристики описываемого индекса используется несколько десятков факторов. Одна группа факторов оценивает наличие, содержание и качество стратегий и эффективность работы компаний; другая используется для оценки качества национального бизнес-климата.

Последние расчеты ИКБ, ставшего ежегодным, охватывают более ста стран и своей целью имеют выявление наиболее существенных факторов, влияющих на развитие экономики. При составлении отчета в качестве зависимой переменной используется размер ВВП на душу населения, скорректированный покупательской способностью в этих странах. Исходные данные представлены количественными и качественными показателями. Первые используются для оценки таких факторов, как число выданных патентов, степень проникновения интернета и сотовой связи и т. п. Однако, вследствие того что большинство характеристик внешней и внутренней сред не поддаются количественному измерению, они оцениваются посредством качественных измерителей, среди которых сложность производственного процесса, уровень подготовки персонала, сотрудничество между исследовательскими учреждениями и промышленностью, характеристики местных поставщиков, наличие венчурного капитала и многие другие.

Следует особо отметить, что незаменимую роль в экономическом развитии играет правительство, так как оно влияет на различные аспекты бизнес-среды. Оно создает факторные условия, например, через образование и инфраструктурную политику. Развитость местного спроса вытекает частично из регулятивных стандартов, законов о защите прав потребителя, правительственной закупочной деятельности и открытости импорту.

В мировой практике процесс создания кластеров рассматривается как элемент экономической стратегии для стимулирования инновационной деятельности. Взяв в качестве основы наиболее передовую в научнотехническом плане компанию, организаторы кластера формируют вокруг нее определенное количество соисполнителей и за счет синергетического эффекта получают на выходе конкурентоспособную продукцию. Кластерный подход позволяет повысить эффективность взаимодействия региональных органов управления, крупных промышленных компаний, предприятий малого и среднего бизнеса, научно-исследовательских и образовательных учреждений и объединить их усилия в инновационном процессе. Кластерный подход может послужить основой для конструктивного диалога между представителями государства и частного бизнеса с целью выявления проблем в развитии науки и производства, поиска путей наиболее эффективной 
реализации имеющихся инвестиционных возможностей и необходимых мер государственной поддержки.

Кластерный подход, как показывает опыт многих стран, служит средством достижения целей промышленной политики (структурных изменений, повышения конкурентоспособности, усиления инновационной направленности и пр.), а также является мощным инструментом для стимулирования развития предпринимательства, что в конечном итоге может влиять на увеличение занятости, заработной платы, отчисления в бюджеты различных уровней, повышение эффективности, устойчивости и конкурентоспособности промышленности.

Кластер является важным компонентом экономического развития региона, поскольку функционирование отдельных промышленных комплексов или малых и средних предприятий, ориентированных на достижение своих целей, не в полной мере отвечает экономическим целям региона. Формирование кластеров способствует возникновению конкурентных преимуществ через местоположение взаимосвязанных предпринимательских структур и стимулирует экономическое развитие региона, т. е. повышается роль предпринимательства, государственных органов и институтов, появляются новые способы улучшения структуры деловых связей и взаимоотношений.

Создание инновационного кластера должно сопровождаться формированием соответствующей инфраструктуры в виде разнообразных организаций, соответствующих реализации конкретных целей кластерной стратегии (бизнес-инкубаторов, технопарков, инновационнотехнологических центров, организаций трансфера технологий).

Передовые в экономическом плане страны давно оценили преимущества кластерного подхода, успешно разрабатывая и используя концепцию формирования промышленных кластеров, которая становится одной из основ инновационной промышленной политики. В конкурентной борьбе, которая, как ни странно, культивируется между участниками кластера, значительно повышается производительность как кластера в целом, так и участвующих в нем государственных структур, крупных компаний, университетов, малых и средних предприятий и др.

Основной целью реализации кластерной политики является повышение конкурентоспособности за счет интеграции деятельности предприятий и организаций, образующих территориально-производственные кластеры. При этом стратегия менеджмента экономических кластеров заключается в анализе и использовании информации о состоянии рынка, возможностях занятия специальных ниш и использовании преимуществ кластера.

В качестве примеров можно привести формирование и развитие кластеров в различных регионах страны и в тех отраслях, где достигнуты реальные результаты создания конкурентоспособных структур.

Так, заслуживает внимания проект Правительства Мурманской области по созданию рыбоперерабатывающего кластера, который предусматривает значительный рост производства продукции за счет переоснащения производственных мощностей, повышения производительности труда и интеграции усилий участников кластера. 
В последние годы сформировались и получили развитие автомобильные кластеры, которые успешно функционируют в ряде регионов России, таких как Санкт-Петербург и Ленинградская область; Набережные Челны, Тольятти и Самара; Москва, Владимир и Калуга.

Интерес представляет проект по созданию кластера в наиболее развитой в Российской Федерации отрасли - нефтепереработке, в частности в Северо-Западном регионе страны, где объединили усилия такие крупные нефтеперерабатывающие компании, как «Новатэк Усть-Луга», «КИНЕФ», «Метахим», «Газпром СПГ». Отличительной особенностью приведенных типов кластера является способность структурной интеграции юридически независимых, но связанных производственной спецификой компаний в эффективную систему управления совершенно новой структурой, обладающей производственно-инновационным потенциалом и необходимым набором инструментов для развития и поддержки экономики региона. Их создание и поддержка позволит значительно ускорить темпы экономического развития региона за счет использования современных методов производственной кооперации и управления.

\section{4. Система подготовки специалистов и руководителей для промышленности Арктики}

Важным фактором развития конкурентного рынка труда в арктическом регионе является повышение качества подготовки кадров, начиная с рабочих специальностей и заканчивая выпускниками высших учебных заведений и школ бизнеса. Существенную роль в решении этой задачи играет кадровая политика государственных органов и руководства компаний, которая определяет эффективность использования трудовых ресурсов. Стратегию кадровой политики, в свою очередь, определяют руководители всех уровней управления, от профессиональной квалификации которых зависят результаты производственно-хозяйственной деятельности региона в целом.

В то же время специалистами в области управления кадрами отмечаются серьезные недостатки в формировании инфраструктуры арктического региона, связанные с потребностью предприятий и организаций в квалифицированных кадрах, а также с качеством их подготовки. Приходится констатировать, что остро ощущается дефицит специалистов, хорошо знакомых со спецификой работы в АЗРФ.

В настоящее время в системе подготовки специалистов и руководителей для нужд Арктики функционирует около тридцати вузов, из них только пять располагаются на территории арктического региона. Непосредственно подготовку кадров для арктического региона осуществляют крупнейшие в АЗРФ Северный (Арктический) федеральный университет им. М. В. Ломоносова (САФУ), Мурманский арктический государственный университет (МАГУ), Мурманский государственный технический университет (МГТУ), Норильский индустриальный институт.

В то же время существующая региональная система подготовки руководителей и специалистов не в полной мере обеспечивает тот уровень знаний, умений и навыков, которые позволяют осуществлять эффективное 
руководство. Отсутствие специальной профессиональной управленческой подготовки ведет зачастую к ошибкам в стратегии развития высшей школы в регионе. Наглядным примером такого рода необоснованного решения служит подготовленное распоряжение о слиянии МГТУ и МАГУ, породившее массу критики и дискуссий о недостаточной его проработке. Этим распоряжением не было учтено, что такому объединению препятствует целый ряд федеральных нормативных актов, начиная с утвержденного Правительством Российской Федерации положения о Минобрнауки Российской Федерации, где в перечне функций ведомства отсутствует имеющееся у Росрыболовства функция обеспечения студентов обмундированием, питанием и практикой плавания под парусами. Если же наделить такой функцией Минобрнауки Российской Федерации, будет нарушено другое постановление, запрещающее дублирование функций госведомств. Следует учитывать и Гражданский кодекс, который не предусматривает реорганизации юридического лица в форме изменения подведомственности.

Следует, по нашему мнению, признать ошибочным и решение, принятое относительно закрытия в МГТУ факультета экономики и управления, который обеспечивал подготовку высококвалифицированных специалистов и руководителей для отраслей арктического региона. Функционировавший при МГТУ совет по присуждению степеней кандидата и доктора экономических наук выполнял важную функцию подготовки высококвалифицированных научно-педагогических кадров, в которых нуждался Кольский научный центр РАН.

Приведенные просчеты в управлении наукой и высшим образованием в регионе свидетельствуют о недооценки роли руководителей в создании эффективной системы управления, недостаточном учете специфики управленческого труда. В специальной литературе длительное время ведутся дискуссии на тему, должен ли быть руководитель производства специалистом в той отрасли, к которой относится руководимый им объект. При этом весьма распространенным является мнение о том, что профессиональному менеджеру не важно, в какой отрасли работать, так как принципы, методы и технологии управления являются общими для любого объекта управления. Другие же специалисты выражают уверенность в том, что менеджер обязательно должен глубоко знать специфику отрасли, пройдя все ступени в иерархии управленческой пирамиды. Оптимальное соотношение управленческих и специальных знаний в содержании труда менеджера устанавливалось эмпирическим путем, и в этой связи важен анализ исторического опыта подготовки управленческих кадров, так как наша страна прошла в этой области достаточно противоречивый путь, не всегда извлекая пользу из совершаемых ошибок и неудач.

Задача подготовки профессиональных управленцев была поставлена еще 150 лет назад, когда занявший пост премьера в правительстве Николая II С. Витте поставил целью создать мощную национальную индустрию, способную завоевать ведущие позиции на международной арене. Важным звеном в решении этой задачи он видел формирование системы подготовки профессиональных управляющих, способных отвечать на новые вызовы. Следует отметить в этой связи его серьезные усилия в создании системы специального обучения профессиональных руководителей производства. 
Путем привлечения частных инвесторов ему удалось открыть и запустить целую сеть учебных заведений, включая высшие и средние профессиональные заведения, где могли обучаться будущие руководители самых различных отраслей, включая промышленность, сельское хозяйство, художественные и научные направления. Высокие темпы развития, которых удалось достигнуть в годы правления С. Витте в качестве премьера, во многом определялись появлением целой команды профессионально обученных кадров хозяйственных руководителей, которые успешно претворяли в жизнь цели и задачи ликвидации векового отставания России от экономически развитых стран Европы и Америки.

После революции задача подготовки управленческих кадров решалась, исходя из имеющихся ресурсов, когда по сокращенным срокам обучения готовились специалисты и руководители через специфическую систему рабфаков, а также в проходящих стадию становления сохранившихся высших учебных заведениях. Одновременно формировалась система подготовки советских руководящих кадров в технических и экономических вузах. Постепенно сложилась своеобразная система их подготовки и продвижения, учитывающая, в первую очередь, их политическую ориентацию. Главенствующим принципом при этом являлся тезис В. И. Ленина о том, что политика первенствует над экономикой, поэтому советский руководитель, во-первых, обязательно должен был быть членом партии, вовторых, продвижение по служебной лестнице предусматривало обязательную работу в партийной организации перед занятием следующей в иерархии управления руководящей должности. В этом случае алгоритм профессионального роста руководителя содержал следующие этапы: мастер участка - член партбюро; начальник цеха - заместитель секретаря партбюро; заместитель директора - член парткома и т. д.

Одновременно продолжались эксперименты по определению содержания труда руководителей, которые готовились как в технических, так и в экономических и финансовых вузах. В этой связи следует отметить опыт Ленинграда, где в 1965 г. в составе Ленинградского инженерноэкономического института был открыт факультет организаторов промышленного производства и строительства, на котором в течение трех месяцев проходили переподготовку директора и главные инженеры, а в течение шести - начальники цехов. Это был, по сути, первый в стране опыт переподготовки профессиональных руководителей производства, в обучении которых присутствовали как технические дисциплины, так и специфические предметы по теории и практике управления. Такие факультеты в СССР были открыты в нескольких городах, среди которых Москва, Ленинград, Минск и Ташкент. Между ними существовала своеобразная конкуренция; проводились совместные конференции и обмен опытом. Широкое распространение получили так называемые школы деловых игр, когда представители этих регионов собирались на базе какоголибо пансионата и в течение двух недель проводились тренинги в области активных методов обучения, специфические именно для категории руководителей производства. В период 2010-2012 гг. в процессе оптимизации системы высшего профессионального образования были объединены петербургские Инженерно-экономический (ИНЖЭКОН) 
и Финансово-экономический (ФИНЭК) университеты, к которым позже был присоединен Санкт-Петербургский университет сервиса и экономики. Этот шаг был, по нашему мнению, глубоко ошибочным с точки зрения стратегии развития учебной базы для подготовки современных менеджеров, так как ИНЖЭКОН представлял собой идеальную площадку для обучения руководителей, которые получали качественные знания как в области научного менеджмента, так и в области отраслевой специализации. И хотя формально Финансово-экономический университет стал базой для «Института экономики», Инженерно-экономический - для «Института управления», а Университет сервиса и экономики - для «Института сервиса», уникальная научная школа ИНЖЭКОНа, его научнопроизводственная база были разрушены, а профессорско-преподавательский состав в силу чисто политических амбиций ФИНЭКа, ставшего базовым для новой структуры, был постепенно «выдавлен» и перешел в другие институты.

Дефицит специально подготовленных современных менеджеров, в содержании труда которых гармонично сочетались бы знания в области научного менеджмента и отраслевой специфики, привело к появлению «новых эффективных менеджеров», имевших в лучшем случае экономическую подготовку, в худшем - финансовую, главными целями деятельности которых были получение прибыли любой ценой и способность управлять финансовыми потоками на фоне полного отсутствия инициативы и самостоятельности и четкого исполнения указаний вышестоящего начальства.

Можно привести целый ряд примеров, характеризующих результаты деятельности «новых эффективных менеджеров», руководящих ведущими предприятиями таких отраслей, как судостроение, станкостроение, культура, образование, медицина. Анализ этих результатов свидетельствует об одном: руководить производством должны профильные специалисты, знающие специфику объекта управления. То же относится к предприятиям сферы услуг, туристической отрасли, ресторанному бизнесу, спорту и другим отраслям.

Опасность появления категории «новых эффективных менеджеров», не обладающих компетенциями профессиональных менеджеров в конкретной отрасли, привело к распространению опасной практики «ручного управления», когда топ-менеджеры пытаются лично решать текущие задачи в ущерб стратегическим, вследствие чего верхний уровень не может своевременно отреагировать на внешние угрозы. Режим «ручного управления» наглядным образом проявляется в случае возникновения чрезвычайных и трагических ситуаций, когда можно решить ограниченное количество «горящих» проблем, однако глубинная перестройка всей структуры управления требует системных мер.

Не менее опасные последствия влечет игнорирование современными российскими менеджерами важнейшего принципа управления, связанного с рациональным делегированием управленческих функций. Их стремление решать все вопросы на высшем уровне управления привело к порочной практике «ручного управления», когда даже первые руководители государства пытаются самостоятельно и лично решать все вопросы, начиная от стратегически важных для государства и заканчивая сугубо оперативными 
вопросами, входящими в компетенцию руководителей нижестоящего уровня. В результате верхний уровень управления, будучи перегруженным решением рутинных задач, не имеет возможности заниматься тем, чем должен по определению, а именно выработкой и реализацией стратегии развития национальной экономики. В силу этого руководство ведет себя «реактивно», а не «проактивно» и часто принимает поспешные и не всегда адекватные решения в ответ на экстренные вызовы. Складывается ситуация, когда на нижних уровнях управления никто не берет на себя ответственность, ожидая команды сверху, а верхний уровень вследствие перегруженности не может предвосхитить или своевременно отреагировать на внешние угрозы.

В этой связи интерес представляет фигура менеджера будущего, хорошо образованного, интеллектуального и креативного, имеющего навыки аналитического мышления и готового к компромиссам. Ряд источников представляют перечень качеств, которыми должен обладать такой менеджер. Исследовательский центр портала SuperJob.ru в июне 2008 г. провёл экспертный опрос среди ста директоров предприятий с целью выяснить, какими основными качествами должен обладать топ-менеджер. Респондентам был задан открытый вопрос: «Назовите, пожалуйста, три главных качества настоящего топ-менеджера» [20].

Как показал опрос, главными качествами топ-менеджеров они назвали профессионализм, компетентность и интеллект (22, 18 и $16 \%$ респондентов соответственно). Настоящий топ-менеджер, по их мнению, прежде всего, должен уметь «чётко и ясно обозначить задачи и организовать работу по их решению», «применять свои знания на практике», а также обладать аналитическим складом ума и широким кругозором.

Целеустремлённость и стратегическое мышление отметили $16 \%$ респондентов. По мнению участников опроса, квалифицированного управленца характеризует нацеленность на результат, а также умение просчитывать развитие ситуации на несколько шагов вперёд.

Топ-менеджер - одна из наиболее значимых фигур в компании, а потому неудивительно, что человек, занимающий эту должность, должен обладать такими качествами, как ответственность и решительность. Их указали 15 \% респондентов. Умение убеждать, т. е. наличие лидерских качеств, считают необходимым для топ-менеджера $12 \%$ опрошенных. По мнению $11 \%$ респондентов, плодотворная работа на позиции топменеджера невозможна без наличия такого качества, как устойчивость к нервным перегрузкам.

Таким образом, можно сделать вполне конкретный вывод, что в подготовка профессиональных менеджеров в стране имеет ряд принципиальных проблем, связанных со сложившейся системой формирования резерва руководителей, ориентированных на строгое следование специфическим принципам работы в команде, которые вступают в явное противоречие с классическими принципами научного менеджмента, принятыми во всем мире. 


\section{ГЛава 3. ПРОМЫШЛЕННЫЕ КОРПОРАЦИИ В НЕФТЕГАЗОВОЙ ОТРАСЛИ АРКТИКИ}

\section{1. Формы и методы взаимодействия холдинговой и сервисных структур}

Предпринимательская структура - это самостоятельный хозяйствующий субъект, созданный для производства продукции, выполнения работ и оказания услуг с целью удовлетворения общественных потребностей и получения прибыли.

Переход к рынку влечет за собой коренные изменения в формах хозяйствования, отношениях между собственниками, организаторами производства и наемными работниками. Предприятие предоставляет рабочие места, выплачивает заработную плату. Путем выплаты налогов оно участвует в реализации государственных программ, развитии экономики страны. Это означает, что в условиях рыночных отношений предприятие есть самоорганизующийся и самовоспроизводящийся социальнопроизводственный организм, автономный центр производственных, хозяйственных и социальных решений.

Экономическая обособленность проявляется, во-первых, в имущественной обособленности. Предприятие располагает собственным имуществом владельцев, а также может арендовать или на иных договорных началах использовать различные ресурсные элементы - землю, капитал и другие. Во-вторых, предприятие имеет завершенный воспроизводственный цикл: оно мобилизует ресурсы, преобразует их и получает готовый продукт, реализует его и полученную выручку использует вновь для приобретения ресурсов. Поэтому предприятия - это обособленные экономические структуры. Их обособленность обусловливается товарным характером общественного производства.

В силу обособленности предприятия самостоятельны: в производственной деятельности (что и сколько производить, как производить); в коммерческой деятельности (что и сколько продавать, покупать, распределять); в распределении производственного продукта (что идет на собственные нужды, а сколько на обмен и накопление и т. д.).

Из вышеизложенного следует, что предпринимательские структуры ориентированы на извлечение прибыли за счет собственных усилий и возможностей, а их конкурентоспособность ограничена действием внешних контрагентов рынка и конкурентов. Таким образом, предпринимательская структура самостоятельно выбирает направления развития своей конкурентоспособности и удержания собственных конкурентных преимуществ.

Это подтверждается и рядом течений в теории конкуренции. К примеру, ряд специалистов считает [37], что одним из условий обеспечения конкурентного преимущества является экономическая обособленность или автономность производителей, возможность или свобода для каждого экономического субъекта стремиться к обеспечению своих частных интересов и разделения труда между товаропроизводителями. Товарный 
обмен предполагает обязательное стремление к эквивалентности, которое возникает на основе экономической ограниченности, обособленности интересов. Эта обособленность исторически возникает на основе частной собственности, в дальнейшем она начала опираться и на коллективную собственность, но обязательно ограниченную каким-либо локальным кругом интересов (кооперативы, товарищества, акционерные общества, государственные предприятия, смешанные предприятия, т. е. с государственным участием и т. д.).

В соответствии с данным положением предпринимательская структура может избрать несколько направлений своей деятельности и повышения конкурентоспособности, ориентированных на самостоятельное, обособленное функционирование. Данные направления деятельности будут рассмотрены позже.

С другой стороны, современное состояние экономики, тенденций её развития говорит о том, что собственных ресурсов предпринимательским структурам в должной мере не хватает. И если у крупных предприятий за счет имущественного положения, большого количества хозяйственных связей и оборота такого рода проблема стоит в меньшей мере, то для малого и среднего бизнеса зачастую данное положение является вопросом выживания.

В связи с этим появляются новые особенности в деятельности указанных групп предпринимательских структур, одной из которых является организация взаимодействия между ними. При этом взаимодействия приобретают различный характер: от простого (взаимодействия между предпринимательской структурой и потребителем) до сложного (взаимодействие с прямыми конкурентами для завоевания рынка при сохранении собственных интересов).

Таким образом, видно, что в современных условиях предпринимательские структуры могут самостоятельно определиться с выбором: осуществлять обособленно свою деятельность, полагаясь на собственные силы, либо идти на сотрудничество с иными предприятиями, что может привести к потере самостоятельности.

В связи с дискуссионностью данного вопроса появляется необходимость рассмотреть его более подробно.

В основе конкурентного поведения и выбора направления развития субъектами предпринимательского бизнеса лежит рациональное начало. В зависимости от обстоятельств одни фирмы стратегически нацеливают действия на устранение соперников, другие - на обособление от них, третьи - на сближение с ними, четвертые - на сдачу им позиций на выгодных условиях. Поэтому целесообразно выделение различных направлений конкурентного поведения, которыми могут воспользоваться субъекты бизнеса в процессе межфирменного соперничества (рис. 9).

Выбор направления конкурентного поведения компании следует нацелить на увеличение ее стратегических конкурентных преимуществ, которые нуждаются в положительной оценке со стороны внешнего окружения этой компании. Предприятию необходимы формирование и реализация установок на усиление и обеспечение большей устойчивости стратегических конкурентных позиций. В зависимости от целевых установок 
фирма-конкурент может, соперничая за наилучшие конкурентные позиции, применять в отношении конкурентов [42]: механическую монополизацию, интегрирующую консолидацию, простое и дезинтегрирующее обособление, полное обособление (изоляция) бизнеса, кооперативную солидарность, компромиссное сотрудничество, вхождение в бизнес и уход из бизнеса.

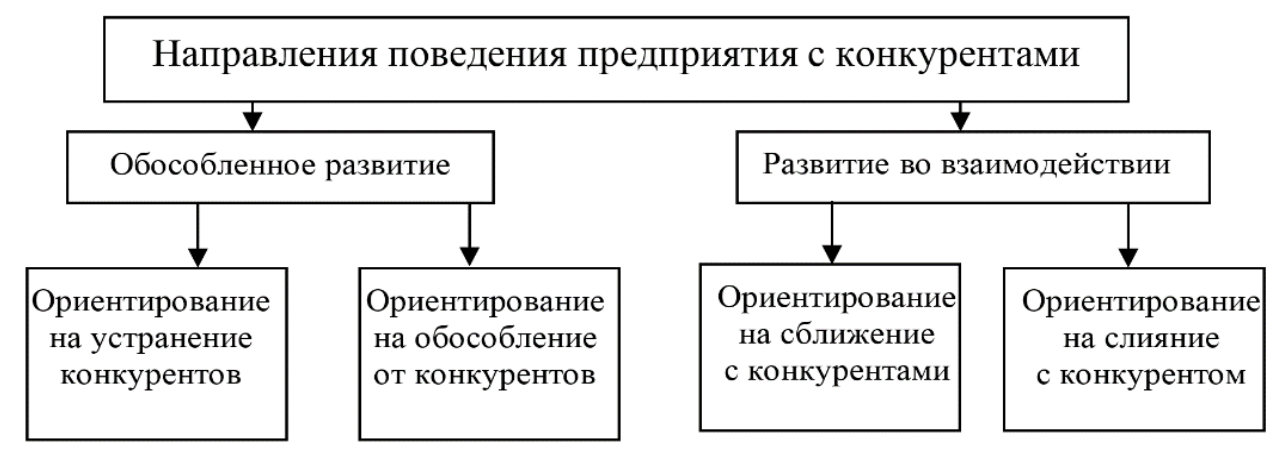

Рис. 9. Направления конкурентного развития

Bce направления конкурентного поведения, за исключением стратегий ухода из бизнеса, нацеливают фирму на выживание, последние в ряду упомянутых стратегий нацеливают ее на достойное либо недостойное завершение деловой деятельности.

Механическая монополизация опирается на целевую установку, направленную на вытеснение конкурентов с рынка, как правило, силовыми методами посредством ослабления и уничтожения конкурентов. Она представляет собой последовательный процесс наращивания стратегических конкурентных преимуществ предпринимательской структуры за счет прямого (механического) воздействия на другие предпринимательские фирмы, действующие на аналогичном сегменте рынка, в целях синхронного уменьшения конкурентных преимуществ данных фирм. Следствием этого становится достижение монопольного положения на рынке соответствующего товара (услуги).

Субъъект бизнеса, стремящийся к механической монополизации рынка, тщательно присматривается к конкурентам, изучает их сильные и слабые стороны, «нащупывает» их уязвимые места, прежде чем начнет осуществлять данное направление конкурентной борьбы.

Фирма, стремящаяся к усилению своих конкурентных позиций с помощью рассматриваемого направления, как правило, выдвигает целевую установку не просто на пресечение деятельности конкурента. Она заинтересована и в том, чтобы данный конкурент прекратил свою деятельность, и в том, чтобы механически, путем его устранения, отобрать его бизнес, сделать чужой бизнес своим исключительным достоянием. Это становится возможным в том случае, когда конкурент просто вытесняется со своих позиций (такое положение свидетельствует о выполнении механическим монополистом задачи-минимума), а также когда занимаемые конкурентом позиции (прежде всего его рыночная доля) достаются 
монополисту (захват чужой конкурентной позиции свидетельствует о выполнении механическим монополистом задачи-максимума).

Применение механической монополизации в отношении стратегических соперников связано с немалыми рисками и таит в себе ощутимую угрозу безопасности собственного бизнеса. В такой ситуации субъекты предпринимательского бизнеса, стремящиеся к стратегическому доминированию, часто могут быть мотивированы на применение интегрирующей консолидации.

Указанный тип рассматриваемого конкурентного поведения может применяться в отношении прямых конкурентов и партнеров по цепочкам ценностей, действующих в смежных областях бизнеса. Принимая на вооружение направление интегрирующей консолидации, менеджмент сильной фирмы-интегратора опирается на положительные оценки тех или иных сторон деятельности прямых конкурентов или партнеров по бизнесу. Рассматриваемое направление конкурентного поведения оказывается предпочтительней механической монополизации также в том случае, если менеджмент фирмы изначально не уверен в победоносном завершении войны со своим окружением. В любом случае использование сильных сторон, достижений, возможностей и конкурентных преимуществ прямых конкурентов, и тем более партнеров по бизнесу, в своих интересах представляется более привлекательной задачей, нежели механическое уничтожение названных субъектов предпринимательского бизнеса.

Сильные стороны могут быть обнаружены в различных аспектах деятельности прямых конкурентов, например, в разнообразии ассортимента предлагаемых товаров и услуг, передовой технологии, плодотворных бизнесидеях, эффективном менеджменте. Каждая из этих сторон, а то и все они вместе, могут быть использованы во благо сильного интегратора, если у его руководства хватит профессиональных знаний и навыков для проведения достаточно тонко работы по вербовке сотрудников бывшего конкурента.

Направление простого обособления применяется обычно субъектами малого предпринимательского бизнеса в сферах, традиционно обслуживаемых только мелким бизнесом (по терминологии А. Ю. Юданова [75] - коммутантами). Как нам известно, иные области производственного бизнеса, а также бизнеса в сфере разнообразных услуг населены сотнями, и даже тысячами, мелких и средних фирм, причем ни одна из них не играет существенной роли в общем объеме продаж ни на одном локальном рынке. Подобный бизнес разворачивается в раздробленных областях деловой деятельности, отличительной чертой которых являются отсутствие на соответствующих секторах рынка фирм с доминирующими конкурентными позициями и принципиальная невозможность приобретения таких позиций какой-либо компанией.

Простое обособление базируется на относительной краткосрочности стратегического периода деловой деятельности рассматриваемых компаний. Компания, не обладающая реальными финансовыми инвестиционными возможностями планомерного развития деловой деятельности, не может позволить себе роскошь составления среднесрочных и тем более долгосрочных планов. Обозримое будущее для нее - это скоротечные обороты капитала, нахождение и быстрое насыщение небольших и не очень 
емких ниш либо крайне узкая специализация бизнеса, например, оказание услуг постоянным покупателям и VIP-клиентам.

В отличие от приверженцев простого обособления предпринимательские структуры, использующие направление полного обособления, обязательно стремятся либо специализироваться на чем-либо важном для рынка, либо уклониться от борьбы на любом невыгодном конкурентном поле. Поэтому полное обособление бизнеса и представляет собой особую направленность конкурентного поведения предпринимательских фирм.

В том случае, когда субъекты бизнеса в качестве главной целевой установки выдвигают стремление найти либо сконструировать «собственную» нишу, а впоследствии стараются удержать ее, не вступая в прямое столкновение ни с одним из вероятных прямых конкурентов, а также в любом случае уклонения субъектов бизнеса от борьбы, перед нами стратегия конкурентного поведения, которую здесь и далее называем направлением полного обособления бизнеса.

Взаимно конкурирующие субъекты предпринимательского бизнеса не всегда стремятся уничтожить своих стратегических соперников. Весьма часто взаимодействие предпринимательских структур с отдельными конкурентами представляет собой реализацию кооперативной солидарности, которая базируется на целевых установках, согласно которым фирма может сотрудничать с конкурентами и действовать с ними совместно как в отношении конкурентов, так и в отношении иных представителей общего внешнего окружения.

Объективными причинами, обусловливающими выбор кооперативной солидарности, являются относительная слабость конкурентного потенциала фирмы, стратегическая зависимость ее собственной деятельности от возможностей внешнего окружения, часто обусловленная, в свою очередь, особенностями предметной и технологической компоненты ее основного бизнеса. Компания, с одной стороны, оказывается слишком слабой для достижения стратегической независимости от окружения, a с другой стороны, достаточно сильной, чтобы, рискнув, пойти на кооперацию с другой компанией, которая может на поверку оказаться сильным интегратором и запросто поглотить своего недавнего партнера по кооперационным связям.

Компромиссное сотрудничество является наиболее трудным для описания направлением конкурентного поведения субъектов предпринимательского бизнеса. Оно базируется, как и кооперативная солидарность, на возможности и необходимости сотрудничества компаний, которые, в принципе, конкурируют между собой. Однако в отличие от кооперативной солидарности ключевое значение при формулировании указанного направления имеет не солидарность, а компромисс. Применяя направление компромиссного сотрудничества, субъекты бизнеса не помышляют ни о какой общности интересов с конкурентами, они сотрудничают не против третьей стороны - общих соперников - и не за превращение конкурентов в партнеров по бизнесу. Их целевые установки связаны лишь с нахождением и исполнением решений, которые устраивали бы обе стороны. 
Поиск таких решений обязательно предполагает принятие компромисса. Под компромиссом в бизнесе следует понимать фактическое признание субъектами деловых отношений законных интересов своих конкретных прямых, условно-прямых и косвенных конкурентов и последующую ориентацию конкурентных действий на то, чтобы данные интересы не были нарушены.

Речь идет не о теоретическом допущении наличия у всех субъектов бизнеса права на участие в конкуренции. Реальным конкурентам приходится иметь дело не с бумажными соперниками, на которых можно поглядывать умозрительно и издалека, а с совершенно конкретными. Для достижения компромисса с ними субъекты предпринимательского бизнеса не только учитывают деловые интересы представителей своего окружения (они обязаны делать это постоянно, если не желают получить стратегический провал), но и принимают обязательства по их соблюдению, нередко даже ценой собственных интересов.

Такой выбор представляется для многих субъектов бизнеса стратегически важным, когда они, с одной стороны, желают не вступать в явное соперничество с конкурентами, стремятся уклониться от него, приспособить свои действия под бизнес-идею ненападения на соперника, a c другой стороны, усматривают в поведении соперника аналогичные признаки. Важно подчеркнуть, что применение рассматриваемого направления ни в коем случае не следует воспринимать как заблаговременную сдачу компаниями стратегически важных конкурентных позиций. Ведь в еe конструкции существенное место, наряду с компромиссом, занимает сотрудничество.

В процессе определения направления развития предпринимательской структуры и установления отношений с конкурентами, она может использовать сочетание тех или иных направлений конкурентного поведения. Итоги рассмотрения вышеуказанных направлений представлены в табл. 7.

Одним из способов добиться более выгодных условий хозяйствования является использование концепции конкуренции на основе сотрудничества. Она заключается в том, что те руководители, которые лучше всех сотрудничают, лучше всех и конкурируют. Сотрудничество подразумевает формирование отношений между фирмами, идущих дальше обычного делового партнерства, но не доводящих дело до юридического слияния. Оно предполагает проведение совместных исследований, обмен технологиями, совместное использование производственных мощностей, объединение усилий в производстве компонентов или сборке конечной продукции, продвижение на рынок продукции друг друга.

Закономерностью конкуренции является и развитие между субъектами конкуренции отношений «взаимного притяжения» в виде разного рода объединений (ассоциаций, союзов), организационного слияния и других форм кооперации. 
Направления конкурентного развития

\begin{tabular}{|c|c|c|c|c|c|c|c|}
\hline & Монополизация & \begin{tabular}{|c|} 
Интегрирующая \\
консолидация
\end{tabular} & $\begin{array}{c}\text { Простое } \\
\text { обособление }\end{array}$ & $\begin{array}{c}\text { Дезинтегрирующее } \\
\text { обособление }\end{array}$ & $\begin{array}{c}\text { Полное } \\
\text { обособление }\end{array}$ & \begin{tabular}{|c|} 
Кооперативная \\
солидарность
\end{tabular} & $\begin{array}{l}\text { Компромиссное } \\
\text { сотрудничество }\end{array}$ \\
\hline \multicolumn{8}{|c|}{ Преобладающий мотив } \\
\hline Монополизация & + & + & & & & & \\
\hline Обособление & & & + & + & + & & \\
\hline Сотрудничество & & & & & & + & + \\
\hline \multicolumn{8}{|c|}{ Размер предприятия } \\
\hline Крупное & + & + & + & + & - & + & + \\
\hline Среднее & - & $\begin{array}{l}- \\
+\end{array}$ & $\begin{array}{l}- \\
+\end{array}$ & $\begin{array}{l}- \\
+\end{array}$ & + & $\begin{array}{l}- \\
+\end{array}$ & $\begin{array}{l}- \\
+\end{array}$ \\
\hline Малое & - & - & + & - & + & + & $\begin{array}{l}+ \\
-\end{array}$ \\
\hline \multicolumn{8}{|c|}{ Специиализачия } \\
\hline Специализированные & $\begin{array}{l}+ \\
- \\
-\end{array}$ & $\begin{array}{l}+ \\
-\end{array}$ & $\begin{array}{l}+ \\
-\end{array}$ & - & + & + & $\begin{array}{l}+ \\
-\end{array}$ \\
\hline Неспециализированные & + & $\begin{array}{l}+ \\
-\end{array}$ & + & + & - & + & $\begin{array}{l}- \\
+\end{array}$ \\
\hline \multicolumn{8}{|c|}{ Сочетание направлений } \\
\hline Монополизация & & + & $\begin{array}{l}- \\
+ \\
\end{array}$ & - & $\begin{array}{l}+ \\
- \\
\end{array}$ & $\begin{array}{l}- \\
+ \\
\end{array}$ & $\begin{array}{l}- \\
+ \\
\end{array}$ \\
\hline $\begin{array}{l}\text { Интегрирующая } \\
\text { консолидация }\end{array}$ & + & 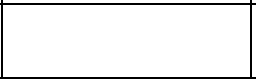 & - & - & $\begin{array}{l}+ \\
-\end{array}$ & - & - \\
\hline Простое обособление & + & + & 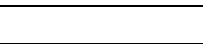 & - & + & + & + \\
\hline $\begin{array}{l}\text { Дезинтегрирующее } \\
\text { обособление }\end{array}$ & - & - & + & & + & + & + \\
\hline Полное обособление & $\begin{array}{l}+ \\
-\end{array}$ & + & - & + & & - & $\begin{array}{l}+ \\
-\end{array}$ \\
\hline $\begin{array}{l}\text { Кооперативная } \\
\text { солидарность }\end{array}$ & - & $\begin{array}{l}+ \\
-\end{array}$ & $\begin{array}{l}+ \\
-\end{array}$ & + & - & & + \\
\hline $\begin{array}{l}\text { Компромиссное } \\
\text { сотрудничество }\end{array}$ & - & $\begin{array}{l}- \\
+ \\
\end{array}$ & - & + & $\begin{array}{l}+ \\
-\end{array}$ & $\begin{array}{l}+ \\
-\end{array}$ & \\
\hline
\end{tabular}


По мнению немецкого экономиста К. Д. Шмидта, групповая конкуренция имеет место, «когда в той или иной отрасли часть предприятий объединяется, чтобы сообща действовать против остальных». Причем такая конкуренция в собственном смысле означает, что объединяются между собой не конкурирующие предприятия одной отрасли. Этой узкой трактовке групповой конкуренции К. Д. Шмидт противопоставляет групповую конкуренцию в широком смысле, при которой объединяющиеся предприятия могут быть конкурентами друг другу, а их совместные действия ограничиваются рядом задач, решение которых координируется за пределами конкуренции [72].

К идее создания стратегических альянсов в научной литературе сложились различные отношения. М. Портер, например, очень осторожно оценивает роль объединений компаний в целях достижения конкурентных преимуществ. В частности, он отрицательно высказывается о горизонтальных слияниях, особенно крупных, лидирующих предприятий, говоря о том, что достижение определенных преимуществ требует значительного объема затрат, которые превращают большинство альянсов в недолговременные переходные образования, а не в стабильные, существующие в течение длительного времени структуры. Что наиболее важно, альянс как всеобъемлющая стратегия будет только обеспечивать заурядность компании, но не лидирование. Ни одна компания не может полагаться на другую внешнюю и независимую компанию в отношении навыков и капиталовложений, составляющих ядро ее конкурентных преимуществ. К альянсам лучше всего относится как к избирательному методу, используемому временно или затрагивающему не основные виды деятельности. Наилучшие объединения зачастую являются переходными образованиями, помогающими фирме развить свои слабые стороны и получить необходимые знания [51].

В условиях рынка стратегическое взаимодействие предприятий призвано уравновешивать нестабильность экономической среды и обеспечивать устойчивость участникам. Вместе с тем сотрудничество предприятий является актуальной общемировой тенденцией, так как гарантирует необходимую гибкость и конкурентоспособность в условиях глобализации. Многие виды стратегического взаимодействия, характерные для ряда зарубежных предприятий и положительно зарекомендовавшие себя в условиях международной конкуренции, такие как, например, территориальные (кластеры, промышленные округа) и ассоциативные (консорциумы, долгосрочные субподрядные соглашения), в российской практике реализуются редко, что делает их использование перспективным направлением управления народным хозяйством.

Более пристальному анализу подвергаются прежде всего дуальные отношения, возникающие между партнерами в цепочке взаимодействия. К параметрам взаимодействия сети могут быть отнесены организационные формы взаимодействия компаний. В широком спектре существующих организационных форм взаимодействия фирм можно выделить по крайней мере три однородные группы: взаимодействие, основанное на различных формах совместной собственности на активы; взаимодействие, построенное на договорных отношениях; неформальные кооперационные соглашения. 
Формально в основе такой классификации лежит степень взаимозависимости и ответственности контрагентов и подразумевается, что она самая высокая при наличии общей собственности и убывает по мере уменьшения степени формализации отношений. Однако практика хозяйствования показывает, что основные различия лежат все-таки в плоскости конкретной организации форм взаимодействия, а на надежность взаимодействия, взаимозависимость и ответственность оказывают влияние не столько единый собственник, сколько факторы иного характера (корпоративная культура бизнеса, история взаимодействия с партнером, субъективные характеристики партнеров и т. п.).

Тем не менее вышеуказанный тип взаимодействия не является единственным, который используют предприятия при организации взаимовыгодной деятельности с иными организациями. Существует ряд иных форм взаимодействия, как больших, так и меньших по силе, которые необходимо рассмотреть с точки зрения использования при формировании стратегии взаимодействия предприятий (табл. 8).

Формы взаимодействия предприятий

Таблицьа 8

\begin{tabular}{|c|c|c|}
\hline $\begin{array}{c}\text { Признак } \\
\text { классификации }\end{array}$ & $\begin{array}{c}\text { Формы } \\
\text { взаимодействия }\end{array}$ & Сущность формы взаимодействия \\
\hline 1 & 2 & 3 \\
\hline \multirow[t]{3}{*}{$\begin{array}{l}\text { Организационные } \\
\text { формы } \\
\text { взаимодействия }\end{array}$} & $\begin{array}{l}\text { Взаимодействие, } \\
\text { основанное на } \\
\text { различных формах } \\
\text { совместной } \\
\text { собственности на } \\
\text { активы }\end{array}$ & $\begin{array}{l}\text { Речь идет о генетически } \\
\text { родственных объектах (например, } \\
\text { дочерних и материнских фирмах). } \\
\text { При этом взаимосвязи предприятий } \\
\text { обычно характеризуются большой } \\
\text { степенью их тесноты (особенно } \\
\text { на первых этапах возникновения } \\
\text { нового предприятия) }\end{array}$ \\
\hline & $\begin{array}{l}\text { Взаимодействие, } \\
\text { построенное на } \\
\text { договорных } \\
\text { отношениях }\end{array}$ & $\begin{array}{l}\text { Основой взаимодействия является } \\
\text { нормативный акт (в большинстве } \\
\text { своем договор о сотрудничестве), } \\
\text { на основании которого происходит } \\
\text { построение взаимной стратегии } \\
\text { взаимодействия }\end{array}$ \\
\hline & $\begin{array}{l}\text { Неформальные } \\
\text { кооперационные } \\
\text { соглашения }\end{array}$ & $\begin{array}{l}\text { Изначально самостоятельные } \\
\text { предприятия впоследствии находят } \\
\text { себе постоянного делового партнера и } \\
\text { образуют альянс с системой тесных } \\
\text { взаимосвязей. В этом случае объекты } \\
\text { обладают родственной системой } \\
\text { экономических интересов, целей и т. д. }\end{array}$ \\
\hline
\end{tabular}


Продолжение таблищь 8

\begin{tabular}{|c|c|c|}
\hline 1 & 2 & 3 \\
\hline \multirow[t]{2}{*}{$\begin{array}{l}\text { Процесс } \\
\text { интеграции }\end{array}$} & $\begin{array}{l}\text { Вертикальная } \\
\text { интеграция }\end{array}$ & $\begin{array}{l}\text { В качестве методов вертикальной } \\
\text { интеграции выступают консолидация } \\
\text { (установление контроля), группировка } \\
\text { (укрепление связей посредством обмена } \\
\text { акциями, представителями в совете } \\
\text { директоров, технологиями т. д.), } \\
\text { франчайзинг (предоставление права } \\
\text { пользования торговой маркой, ноу-хау, } \\
\text { ресурсами и др.), целевая пролонгация } \\
\text { (продление сроков договоров о поставке) }\end{array}$ \\
\hline & $\begin{array}{l}\text { Горизонтальная } \\
\text { интеграция }\end{array}$ & $\begin{array}{l}\text { Предполагает делегирование функций } \\
\text { интегратору, т. е. передачу права решения } \\
\text { ряда вопросов, связанных с интегрируемой } \\
\text { деятельностью, основному предприятию. } \\
\text { Сущность этого типа интеграции состоит в } \\
\text { снижении накала конкурентной борьбы и } \\
\text { достижении взаимовыгодного } \\
\text { сотрудничества между конкурирующими } \\
\text { предприятиями, что ведет к снижению и } \\
\text { устранению рисков, связанных с } \\
\text { поведением конкурентов }\end{array}$ \\
\hline \multirow{4}{*}{$\begin{array}{l}\text { Функциональная } \\
\text { сфера } \\
\text { взаимодействия }\end{array}$} & $\begin{array}{l}\text { Производственно- } \\
\text { хозяйственная }\end{array}$ & \multirow{4}{*}{$\begin{array}{l}\text { Взаимодействие происходит в рамках } \\
\text { одной или нескольких функциональных } \\
\text { сфер каждого предприятия }\end{array}$} \\
\hline & Управление & \\
\hline & Финансы & \\
\hline & Бренд & \\
\hline \multirow[t]{2}{*}{$\begin{array}{l}\text { Масштабность } \\
\text { объектов }\end{array}$} & Одного масштаба & $\begin{array}{l}\text { Взаимодействие предприятий одного } \\
\text { размера: крупное — крупное, среднее - } \\
\text { среднее либо малое - малое }\end{array}$ \\
\hline & Смешанный & $\begin{array}{l}\text { Взаимодействие предприятий различных } \\
\text { размеров. Например, когда крупное } \\
\text { предприятие взаимодействует с сетью } \\
\text { малых для продвижения собственной } \\
\text { продукции }\end{array}$ \\
\hline \multirow[t]{3}{*}{$\begin{array}{l}\text { По объекту } \\
\text { взаимодействия }\end{array}$} & $\begin{array}{l}\text { Интеграция } \\
\text { (с } \\
\text { предприятиями) }\end{array}$ & $\begin{array}{l}\text { Создание условий взаимодействия } \\
\text { предприятий, при которых их интересы и } \\
\text { цели из разнонаправленных становятся } \\
\text { однонаправленными } \\
\end{array}$ \\
\hline & $\begin{array}{l}\text { Коммуникация } \\
\text { (с потребителями) }\end{array}$ & $\begin{array}{l}\text { Влияние на общественное мнение с } \\
\text { помощью рекламной и другой } \\
\text { информационной деятельности } \\
\end{array}$ \\
\hline & $\begin{array}{l}\text { Лоббирование } \\
\text { (с государством) }\end{array}$ & $\begin{array}{l}\text { Использование активов, ресурсов и связей } \\
\text { предприятия для воздействия на процесс } \\
\text { принятия решений в органах власти }\end{array}$ \\
\hline
\end{tabular}


Окончание таблицьы 8

\begin{tabular}{|l|l|l|}
\hline \multicolumn{1}{|c|}{1} & \multicolumn{1}{|c|}{2} & \multicolumn{1}{|c|}{3} \\
\hline $\begin{array}{l}\text { Число участников } \\
\text { и количество } \\
\text { взаимосвязей }\end{array}$ & $\begin{array}{l}\text { Простые } \\
\text { двусторонние связи } \\
\text { двух партнеров }\end{array}$ & $\begin{array}{l}\text { Взаимодействие только двух } \\
\text { предприятий }\end{array}$ \\
\cline { 2 - 3 } & $\begin{array}{l}\text { Множественные } \\
\text { связи нескольких } \\
\text { участников }\end{array}$ & $\begin{array}{l}\text { Создание многосторонних альянсов } \\
\text { в различных формальных и } \\
\text { неформальных формах }\end{array}$ \\
\hline $\begin{array}{l}\text { Устойчивость } \\
\text { взаимосвязей }\end{array}$ & $\begin{array}{l}\text { Экономический } \\
\text { симбиоз }\end{array}$ & $\begin{array}{l}\text { Подразумеваются устойчивые } \\
\text { экономические и организационные } \\
\text { связи, образующие устойчивое } \\
\text { взаимодействие предприятий }\end{array}$ \\
\cline { 2 - 3 } & $\begin{array}{l}\text { Неустойчивое } \\
\text { взаимодействие }\end{array}$ & $\begin{array}{l}\text { Временная форма взаимодействия, } \\
\text { ориентрованная на краткосрочный } \\
\text { период времени либо на достижение } \\
\text { каких-либо частных целей } \\
\text { предприятий }\end{array}$ \\
\hline $\begin{array}{l}\text { По сфере } \\
\text { деятельности }\end{array}$ & Внутриотраслевое & $\begin{array}{l}\text { Взаимодействие предприятий одной } \\
\text { сферы деятельности }\end{array}$ \\
\cline { 2 - 3 } & Межотраслевое & $\begin{array}{l}\text { Взаимодействие предприятий } \\
\text { различных сфер деятельности }\end{array}$ \\
\hline
\end{tabular}

Данная классификация дает представление о множестве форм взаимодействия, которыми могут воспользоваться предприятия для повышения эффективности своей деятельности. Выбор конкретной формы либо нескольких из них во многом зависит от возможностей самого предприятия, а также от тех целей и задач, которые стоят перед руководством конкретного предприятия.

Ниже анализируются отдельные конкретные формы взаимодействия предпринимательских структур.

Взаимодействие, основанное на различных формах совместной собственности на активы. По мере развития российского бизнеса происходит закономерное укрупнение компаний. Формируются филиалы, дочерние и зависимые предприятия, осуществляющие свою деятельность порой вдали от материнской компании. Территориальная удаленность, специфика деятельности, необходимость принятия самостоятельных решений в силу особенностей хозяйственной деятельности и/или необходимости учета местных условий и другие факторы значительно затрудняют управление такими хозяйственными объектами.

Форм интегрирующих систем может быть довольно много. Интегрирующие системы организуются и в процессе преобразования отраслевых министерств и ведомств. В результате формируются холдинги, группы компаний, иные формы хозяйственной интеграции. Имея некоторые различия, определяемые действующей нормативной базой, такие системы имеют и ряд общих свойств, позволяющих их отнести к так называемым интегрированным корпоративным системам. 
Но образовать интегрированную корпоративную систему недостаточно для успеха деятельности. Необходимо организовать еще и эффективное управление дочерними и зависимыми компаниями. Причем, если дочерние компании еще позволяют осуществлять «силовое управленческое воздействие», то статус зависимой компании этого не обеспечивает, что порой ставит в затруднительное положение специалистов материнских компаний при организации управления ими.

Мы рассматриваем вопрос организации управления самостоятельным хозяйственным подразделением, имеющим следующие характеристики (в комплексе или отдельно): 1) возможность или необходимость ведения самостоятельной хозяйственной деятельности (такая возможность может быть как в силу действия законодательства, так и в силу иных обстоятельств, например, значительной удаленности от субъекта управления или специфики деятельности); 2) самостоятельность в принятии определенных решений, которая может быть в силу действия законодательства и/или в силу наличия особенностей деятельности (например, сложность бизнеса или необходимость учета локальных условий); 3) удаленность от субъекта управления, что в значительной степени затрудняет текущий контроль деятельности; 4) наличие, помимо субъекта управления, других значимых участников корпоративных отношений, активных или потенциально активных, имеющих возможность влиять на политику компании (например, акционеров).

Bсе эти факторы в комплексе и по отдельности значительно усложняют процесс управления таким хозяйственным объектом, требуют подчас иных, по сравнению с традиционными, подходов к организации управленческой деятельности, предъявляют более жесткие требования к специалистам, осуществляющим такую деятельность.

Как показали исследования, управление подобными хозяйственными объектами имеет четко выраженную специфику и различается лишь особенностями условий деятельности, которые довольно просто учесть в процессе управления.

Неформальные кооперационные соглашения. Во многих динамично развивающихся странах, где взвешенная государственная политика поддержки предпринимательства направлена на достижение социальноэкономического роста, постепенно происходит процесс активного взаимодействия малых, средних и крупных предприятий. Причем в различных странах с рыночной экономикой обнаружилась общая закономерность, проявившаяся в наиболее успешном развитии сообществ малых и средних предприятий, сгруппировавшихся вокруг лидирующих крупных фирм на основе производственно-технологических, научнотехнических и коммерческих связей в пределах географически ограниченных территорий.

Этот феномен впервые был подробно изучен известным ученым М. Портером при исследовании условий развития и деятельности ста наиболее конкурентоспособных группировок крупных, средних и множества малых предприятий, расположенных в различных странах мира.

Такие группировки предприятий одной отрасли формируются потому, что одна или несколько крупных фирм, достигая конкурентоспособности на мировом рынке, распространяет свое влияние и деловые связи 
на ближайшее окружение, постепенно создавая устойчивую сеть из лучших поставщиков и потребителей. В свою очередь, успехи такого окружения оказывают положительное влияние на дальнейший рост конкурентоспособности всех участников этой группировки компании. Такие образования и есть кластеры. Причем такая совокупность, сочетая свойства отдельных ее элементов в процессе их взаимодействия, приобретает новые качества, которые особенно ярко и разносторонне проявляются в кластерах, образованных субъектами экономической деятельности.

Таким образом, кластер - это сообщество экономически тесно связанных и близко расположенных фирм смежного профиля, взаимно способствующих общему развитию и росту конкурентоспособности друг друга. Преимущественно это неформальные объединения крупных лидирующих фирм с множеством средних и малых предприятий, создателей технологий, связующих рыночных институтов и потребителей, взаимодействующих друг с другом в рамках единой цепочки создания стоимости, сосредоточенных на ограниченной территории и осуществляющих совместную деятельность в процессе производства и поставки определенного типа продуктов и услуг.

Роль крупного бизнеса в процессе образования кластеров заключается в привлечении малых и средних предприятий для налаживания производства на основе тесной кооперации и субконтрактационных связей при активном деловом и информационном взаимодействии. Это способствует развитию всех участников кластера и обеспечивает им конкурентные преимущества по сравнению с другими обособленными предприятиями, не имеющими столь крепких взаимосвязей.

Процесс интеграции (вертикальная интеграция). Рассмотрим совокупность предприятий, которые взаимодействуют между собой для производства какого-либо конечного продукта или услуги в рамках единого полного технологического цикла.

Полный технологический цикл - совокупность технологических операций, выполняемых в определенной последовательности, начиная с переработки сырья, необходимая и достаточная для изготовления конечного продукта [55].

Сырье - исходные по отношению к циклу материалы, из которых в рамках технологического цикла изготавливается конечный продукт.

Таким образом, в рамках полного технологического цикла сырье, подвергнутое переработке по определенной последовательности, превращается в конечный продукт.

Особенность взаимодействия заключается в том, что каждое предприятие совокупности является неотъемлемой ее частью, что позволяет рассматривать совокупность как единое целое при осуществлении процесса управления. Поскольку операции распределены между предприятиями, предприятия можно расположить в порядке выполнения операций по переработке сырья таким образом, что продукция предыдущего является сырьем для последующего. Упорядоченные таким образом предприятия представляют собой технологическую цепочку.

Процесс интеграции (горизонтальная интеграция). На основании исследования различных определений горизонтальной интеграции нами было 
дано следующее определение: горизонтальная интеграция - это интеграция предприятий, находящихся на одинаковых этапах производства, на одном звене торговой цепи, работающих и конкурирующих на одном сегменте рынка, в одной отрасли и специализирующихся на производстве однотипной или сходной продукции или предоставлении однотипных или сходных услуг.

Для характеристики особенностей горизонтальной интеграции необходимо отметить ее роль в экономике. Большинство экономистов указывают на противоречивый характер данного процесса. С одной стороны, горизонтальная интеграция дает ряд преимуществ: 1) слияние может привести к тому, что самый прогрессивный управленческий и технический опыт будет направлен на использование недостаточно эксплуатируемых фондов; 2) слияние может привести к экономии на масштабах производства, что способствует снижению себестоимости, улучшению качества продукции и стимулирует производительность труда; 3) слияние может дать возможность предпринимателю продать свою фирму кому-то, кто уже знаком с этим типом производства и, следовательно, будет занимать более выгодную позицию и заплатит самую высокую цену (перспектива выгодной продажи побуждает предпринимателей основывать новые фирмы, стимулируя конкуренцию, облегчая как выход на рынок, так и уход с рынка; 4) интеграция помогает компаниям преодолевать трудности периода экономической трансформации; 5) в отдельных случаях горизонтальная интеграция позволяет объединять эффекты масштаба и размеры, тем самым сокращать средние издержки на производство продукции (обычно такие типы горизонтальных объединений выгодны и в социальном плане).

С другой стороны, горизонтальная интеграция противоречит сущности рыночной экономики: 1) слияния прямых конкурентов могут привести к приобретению одним из хозяйствующих субъектов значительной власти на рынке, увеличению вероятности того, что остальные хозяйствующие субъекты станут открыто либо тайно координировать свои решения в области ценообразования или объема выпускаемой продукции; 2) проблема состоит в том, что широкомасштабное развитие интегрированных предприятий может привести к концентрации экономической и политической мощи в ограниченном количестве центров влияния, тем самым препятствуя проникновению на рынки новых фирм; 3) данные предприятия могут оказаться менее приспособленными к быстрым изменениям внешней среды, чем независимые малые и средние предприятия.

Горизонтальная интеграция, как правило, применятся тогда, когда отрасль не концентрирована. В этом случае она приводит к сокращению средних издержек на производство продукции и выгодна в социальном плане.

В случае, когда отрасль централизована, горизонтальная интеграция эффективна при следующих условиях: на отраслевом рынке действуют крупные иностранные компании; необходимо освоение новой технологии, ожидается высокая эффективность деятельности новой структуры; одна из компаний, входящая в состав этой новой структуры, испытывает серьезные финансовые трудности.

Функичональная сфера взаимодействия (производственнохозяйственная). Объединение производственных мощностей в единую структуру позволяет не только эффективно управлять производственным 
процессом, обновлять парк технологического оборудования, но и осваивать новейшие технологические процессы, заниматься разработкой и производством новой техники.

Функииональная сфера взаимодействия (бренд). Термин «совместный брендинг» появился в словаре бизнеса относительно недавно. Он используется по отношению к широкому спектру маркетинговой деятельности, в которой участвует два или больше брендов. Таким образом, совместный брендинг можно рассматривать как понятие, которое включает: спонсорство (например, когда Marlboro ставит свое название на машины Ferrari или бухгалтерская фирма Ernst and Young поддерживает выставку Моне); стимулирование розничной торговли (когда сотрудничают McDonald`s и Disney, когда на автозаправочных станциях ВР предоставляется место мини-магазинам Safeway); производственное сотрудничество автомобиль Mercedes-Swatch; кинематограф (когда Mirimax выпускает фильмы, a Buena Vista занимается их прокатом). Список возможностей бесконечен.

Есть два главных критерия, определяющих и категорию сотрудничества, к которой относится определенный проект, и характер практических шагов, которые могут понадобиться. Первый критерий ожидаемая продолжительность сотрудничества, а второй - характер и количество потенциальной ценности, которая может быть создана путем деления или сотрудничества.

Совместный брендинг - это форма сотрудничества между двумя и более брендами, в достаточной степени известными потребителю, в которой сохраняются названия всех брендов.

Продолжительность такого сотрудничества от средней до длительной, a чистый потенциал создания ценности слишком мал для того, чтобы оправдать создание нового бренда и/или совместного предприятия как юридического лица.

Масштабность объектов (одного масштаба). Взаимодействие малых предприятий друг с другом наиболее распространено в тех отраслях, где имеется высокая концентрация малого предпринимательства. Это достаточно новый вид микровзаимодействий в малом бизнесе. При этом в зависимости от генезиса образовавшихся взаимосвязей он может принимать формы дочерних структур и альянсов.

Дочерние структуры - система малых фирм, образовавшихся на базе одного, обычно доминирующего, малого предприятия [44]. Экономическая целесообразность подобных образований кроется, как правило, в попытке максимальной диверсификации производственной деятельности и снижении сбытовых рисков.

Альянсы образуются из первоначально самостоятельных малых предприятий. Как уже указывалось, главной причиной объединения (кооперации) деятельности малых структур является снижение трансакционных издержек в результате наиболее эффективных способов координации работы их участников (оказание взаимной помощи, использование системы взаимозачетов, безвозмездных услуг, общей схемы оптимизации налогообложения, организация «касс финансовой взаимопомощи» и т. д.). Такие формы обычно называются кооперативными 
взаимодействиями, основаны на системе согласованных экономических интересов и являются неформальными, образующимися стихийно, в порядке личной инициативы участников, поскольку законодательная база подобных объединений не разработана.

Структура данного вида взаимодействий малых предприятий не всегда имеет четкие очертания: она не успела выкристаллизоваться вследствие своей относительной незрелости. Однако можно предположить, что формы, разновидности и типы взаимодействий в этом случае будут аналогичными рассмотренным ранее ситуациям взаимодействия малых и крупных предприятий. При этом роль крупного предприятия принадлежит одному доминирующему малому предприятию. Таким образом, с известной долей условности можно говорить о сателлитных формах взаимодействия малых фирм с дипольной, атомарной, сетчатой и корпоративной структурой.

Как следует из этой схемы, тип устойчивых взаимодействий относится к формирующим процессам, т. е. процессам, непосредственно связанным с формированием наиболее стабильной части малого бизнеса, рациональной пропорции между крупным и мелким производством и в конечном счете со становлением предпринимательства как необходимого элемента рыночных отношений.

Другая часть микроэкономических взаимодействий является более мобильной, склонной к изменчивости, перемене организационных форм, готовности начать предпринимательскую деятельность заново. Она относится к трансформационным процессам и в наибольшей степени отвечает за адаптивность малого бизнеса, его проникающую способность и динамичность.

Итак, относительно новым видом микровзаимодействий являются производственно-хозяйственные взаимоотношения, складывающиеся внутри комплекса малых предприятий. Они основаны на системе общих экономических интересов (в частности, оказание взаимной помощи, предоставление информационных услуг, снижение трансакционных издержек и т. д.) и называются кооперационными. Кооперационные взаимодействия предприятий, получившие широкое распространение на Западе, являются перспективным способом организации малого бизнеса и в условиях России. Рассмотрим их более подробно.

Масштабность объектов (смешанный). По тесноте взаимодействия с крупными производственными структурами можно выделить следующие группы малых предприятий.

1. Непосредственно связанные с основным производством крупной фирмы или объединения. Их деятельность бывает достаточно эффективной во взаимодействии с крупными предприятиями в отраслях массового и серийного производства продукции, включая выпуск товаров народного потребления.

2. Не связанные с основным производством, но выполняющие обеспечивающие функции во взаимодействии с крупными предприятиями. Такие малые предприятия создаются во всех отраслях промышленности и могут, в свою очередь, быть сгруппированными по следующим направлениям деятельности: а) занятые научными исследованиями, инновационной деятельностью, маркетингом, инжинирингом, рекламой, консалтингом, т. е. те, без которых процесс реструктуризации крупного предприятия не будет иметь в перспективе должной эффективности; 
б) оказывающие услуги производственного характера по обслуживанию основных производственных процессов: снабженческо-сбытовые, транспортные и складские услуги, работа с кадрами, информационновычислительные и другие услуги (эти малые предприятия позволяют аппарату управления крупных предприятий сосредоточиться на основной производственной деятельности); в) обеспечивающие функционирование социально-бытовых объектов крупных предприятий (такие малые предприятия могут быть временным явлением, наделены полномочиями по решению текущих вопросов, передаче или продаже данных объектов).

Практически во всех отраслях промышленности эффективность взаимодействия малых и крупных субъектов хозяйствования связана с повышением конкурентоспособности продукции как на внутреннем, так и на внешних рынках. Кроме того, для всех отраслей, в том числе и нефтяной, прежде всего с непрерывным, длительным циклом производства, малые предприятия могут брать на себя функции охраны окружающей среды, ремонта, в том числе сервисного. Они могут участвовать в создании рекламно-выставочной деятельности и продвижении продукции на отечественных и внешних рынках.

При разработке механизма стратегического взаимодействия между малой и крупной фирмами инициатором является, как правило, более крупная фирма, которая осуществляет целевые постановки и реализует практические шаги.

Устойчивость взаимосвязей (неустойчивое взаимодействие). Проявлением данного направления взаимодействия является консорциум, на примере которого можно пояснить сущность неустойчивого взаимодействия.

Два и более учебных заведения могут объединяться в консорциумы, совместно используя учебные материалы и деля между собой обязанности. Так, одно из них может взять на себя ответственность за подготовку средств обучения, другое выделяет преподавателей или обеспечивает аккредитацию. В качестве партнеров могут выступать университеты (специализированные или с двумя формами обучения) либо университетские факультеты, государственные учреждения, коммерческие компании, радио, телевидение и другие средства массовой информации.

Члены консорциума сохраняют собственную административную структуру, хотя, если объединение функционирует на демократических началах, частично утрачивают автономность. Каждый член консорциума, как правило, имеет собственный контингент учащихся. Должным образом организованный консорциум - это не просто соглашение о сотрудничестве между различными образовательными учреждениями (что, впрочем, также является одной из возможных моделей). Консорциум подразумевает использование единых учебных ресурсов. Следует определиться относительно того, куда зачисляются студенты: в консорциум или в составляющие его отдельные учебные заведения, а также является ли консорциум учреждением, выдающим дипломы.

Успех или провал деятельности консорциума во многом зависит от координационных механизмов. Если они функционируют слабо, поставленных целей достичь не удастся. Если же созданы необходимые 
условия для максимального использования творческого потенциала всех организаций-членов, то можно рассчитывать на большие достижения.

Модель консорциума имеет много разновидностей. Часто в консорциум объединяются высшие учебные заведения, иногда с привлечением специально учрежденных коммерческих отделений, а также частные компании, осуществляющие онлайн-доставку информации и учебных курсов, созданных с использованием веб-технологий.

Примерами консорциумов, функционирующих в различных странах, могут служить Государственный технологический университет (National Technological University) в CШA, NETTUNO и CUD в Италии, Агентство открытого обучения (Open Learning Agency) и Contact North / Contact Nord в Канаде.

Следует отметить, что взаимодействие предприятий друг с другом должно всегда реализовываться в рамках существующего правового поля. Это обусловлено тем, что формирование системы нормативных документов будет способствовать, во-первых, разграничению и четкому определению областей взаимодействия, а во-вторых, конкретизировать основные функции, выполняемые каждой предпринимательской структурой, что позволит снизить риск возникновения разногласий между данными организациями.

При этом важным является уровень (или степень) тесноты взаимодействия между предпринимательскими структурами. Для более четкого понимания данного вопроса автором предлагается так называемая иерархия взаимодействия предпринимательских структур. Данная иерархия и характерные особенности каждого уровня представлены в табл. 9.

Таблица 9

Иерархия взаимодействия предпринимательских структур

\begin{tabular}{|l|l|l|l|}
\hline Уровень & Теснота связи & \multicolumn{1}{|c|}{$\begin{array}{c}\text { Направления } \\
\text { взаимодействия }\end{array}$} & Пример взаимодействия \\
\hline I & Формальная & $\begin{array}{l}\text { Заключение договоров о } \\
\text { купле-продаже, } \\
\text { планомерных поставок, } \\
\text { обслуживания }\end{array}$ & $\begin{array}{l}\text { Любые сделки } \\
\text { предпринимательских } \\
\text { структур }\end{array}$ \\
\hline II & Слабая & $\begin{array}{l}\text { Обмен ресурсами для } \\
\text { обоюдного повышения } \\
\text { конкурентоспособности }\end{array}$ & Аутсорсинг \\
\hline III & Средняя & $\begin{array}{l}\text { Выделение ИТ- } \\
\text { подразделений из крупных } \\
\text { компаний, работа с ними }\end{array}$ \\
\hline IV & Сильная & Объединения предприятий & Концерны, консорцимы \\
\hline V & Сильная & $\begin{array}{l}\text { Сетевое взаимодействие, } \\
\text { горизонтальное, } \\
\text { вертикальное объединения }\end{array}$ & $\begin{array}{l}\text { Сетевые } \\
\text { предпринимательские } \\
\text { струкуры }\end{array}$ \\
\hline VI & Поглощающая & $\begin{array}{l}\text { Слияние, поглощение } \\
\text { предприятий }\end{array}$ & $\begin{array}{l}\text { Объединение предприятий } \\
\text { в ОК «Русский алюминий» }\end{array}$ \\
\hline
\end{tabular}

Таким образом, при организации взаимодействия следует учитывать степень предполагаемого сотрудничества и тесноту будущих связей, поскольку каждое из вышеуказанных направлений обладает своим набором преимуществ и недостатков. 


\section{2. Современное состояние и перспективы развития корпораций на рынке сервисных услуг}

Основными факторами, сдерживающими развитие НГК, являются.

1. Практика продления ресурса оборудования закладывает будущее отставание в эффективности основного производства. Наблюдается высокая аварийность ключевого оборудования, обусловленная низкой производственной дисциплиной персонала, недостатками управления, а также стремительным старением основных фондов.

2. Сохраняющийся в отраслях комплекса (кроме нефтяной) дефицит инвестиционных ресурсов и нерациональное их использование. При высоком инвестиционном потенциале НГК приток в него внешних инвестиций составляет менее $30 \%$ от общего объема финансирования капитальных вложений. При этом $95 \%$ из перечисленных инвестиций приходится на нефтяную отрасль. В газовой промышленности не создано условий для необходимого инвестиционного климата, в результате чего эти отрасли могут стать тормозом начавшегося, по мнению многих современных экспертов, экономического роста.

3. Деформация соотношения цен на взаимозаменяемые энергоресурсы привела к отсутствию конкуренции между ними и структуре спроса, характеризующейся чрезмерной ориентацией на газ. Политика поддержания низких цен на газ в перспективе может иметь следствием нарастание дефицита ключевых энергоресурсов как результат отсутствия экономических характеристик для инвестирования в их производство и возобновление на основании опережающего роста объемов спроса.

4. Несоответствие производственного потенциала НГК мировому научно-техническому уровню развития техники и технологии переработки ключевых ресурсов НГК. Доля продукции нефтепереработки, получаемой по новейшим технологиям, повышающим качество конечной продукции для потребителя, низка. Энергетическое оборудование, используемое в газовой отрасли, неэкономично.

5. Отсутствие рыночной инфраструктуры и цивилизованных локальных рынков нефтепродуктов. Не обеспечивается необходимая прозрачность хозяйственной деятельности предпринимательских структур, представляющих собой естественные монополии, что негативно сказывается на качестве государственного регулирования предпринимательской деятельности и развитии конкуренции в целом по отрасли.

6. Сохраняющаяся высокая нагрузка на экологию. Несмотря на произошедшее за последнее десятилетие снижение добычи и производства топливно-энергетических ресурсов, отрицательное влияние деятельности предпринимательских структур НГК на окружающую среду остается высоким.

7. Высокая зависимость предпринимательских структур НГК и, как следствие, доходов государства от состояния и конъюнктуры мирового энергетического рынка нефти.

Наблюдается тенденция к дальнейшему повышению доли нефти и газа в структуре российского экспорта, вместе с тем недостаточно используется потенциал экспорта других энергоресурсов, вырабатываемых 
современными предпринимательскими структурами. Это свидетельствует о продолжающемся сужении экспортной специализации экономики страны на мировом рынке и отражает отсталую структуру всей экономики России.

Современные исследователи отраслевых особенностей развития предпринимательских структур НГК выделяют правовые, внешнеэкономические, отраслевые и производственные факторы развития (рис. 10).

\begin{tabular}{|c|c|c|c|}
\hline \multicolumn{4}{|c|}{ Факторы развития предпринимательских структур нефтегазового сектора } \\
\hline$\downarrow$ & $\downarrow$ & $\downarrow$ & $\downarrow$ \\
\hline $\begin{array}{c}\text { Правовые и } \\
\text { общегосударственные }\end{array}$ & Внешнеэкономические & Отраслевые & Производственные \\
\hline Высокое налогообложение & \multirow{3}{*}{$\begin{array}{c}\text { Экспорт начальных } \\
\text { энергоресурсов в ущерб } \\
\text { интересам страны }\end{array}$} & $\begin{array}{c}\text { Проблемы конкуренции } \\
\text { предпринимательских } \\
\text { структур смежных отраслей }\end{array}$ & $\begin{array}{c}\text { Устаревшее оборудование } \\
\text { и большой износ основньх } \\
\text { средств }\end{array}$ \\
\hline $\begin{array}{c}\text { Ущерб окружающей среде } \\
\text { и природным ресурсам страны }\end{array}$ & & $\begin{array}{c}\text { Отсутствие рыночной } \\
\text { инфраструктуры и } \\
\text { цивилизованного рынка }\end{array}$ & $\begin{array}{c}\text { Ввод в действие новых } \\
\text { производственных } \\
\text { мощностей }\end{array}$ \\
\hline $\begin{array}{c}\text { Отсутствие развитого и } \\
\text { стабильного законодательства, } \\
\text { учитывающего в полной мере } \\
\text { специфику функционирования } \\
\text { предпринимательских структур }\end{array}$ & & $\begin{array}{c}\text { Несоответствие } \\
\text { производственного } \\
\text { потенциала мировому } \\
\text { научно-техническому } \\
\text { уровню }\end{array}$ & $\begin{array}{c}\text { Отставание развития и } \\
\text { объективный рост затрат на } \\
\text { освоение перспективной } \\
\text { сырьевой базы добычи } \\
\text { углеводородов }\end{array}$ \\
\hline
\end{tabular}

Рис. 10. Факторы развития предпринимательских структур НГК

Однако, исходя из особенностей основополагающих идей предпринимательства, современными учеными опускаются из исследования следующие факторы.

1. Рост потребления энергоресурсов подталкивает предпринимательские структуры к освоению инноваций для извлечения большего количества энергоресурсов и повышения их качественных характеристик. Эффективное взаимодействие сервисных и производящих предпринимательских структур при освоении инноваций обеспечивает бесперебойность основного производства.

2. Зависимость цен на сырье в стране от мировых цен диктует необходимость внедрения технически сложного, автоматизированного оборудования, инновационных решений в технологическом процессе, направленных на повышение фондоотдачи и уменьшение ресурсоемкости основного производства. Эффективное решение сочетания этих задач может быть достигнуто лишь в гармоничном взаимодействии и развитии сервисных и производственных предпринимательских структур НГК.

3. Объективный рост затрат на освоение перспективной сырьевой базы добычи углеводородов. Инновационные решения, которые гибко реализуют сервисные предпринимательские структуры НГК, во многом определяют соразмерность затрат на освоение перспективной сырьевой базы с ожидаемыми экономическими результатами добывающих и перерабатывающих предпринимательских структур НГК.

Эти факторы наиболее весомо оказывают влияние на развитие предпринимательских идей, связанных с формированием, внедрением 
и развитием инноваций. Действительно, именно этот набор факторов является главным импульсом, активизирующим предпринимательскую активность взаимодействующих предпринимательских структур НГК.

Под проблемами, препятствующими развитию предпринимательских структур НГК, в работе понимаются положения, причинность, условия, вопросы, объекты, которые создают затруднения и связаны с избыточностью или недостатками деятельности субъектов рыночных отношений для реализации эффективных взаимодействий предпринимательских структур НГК.

В исследовании проведена группировка проблем, препятствующих поступательному развитию предпринимательских структур НГК по направлениям: экономика, политика, экология, социальная сфера (рис. 11).

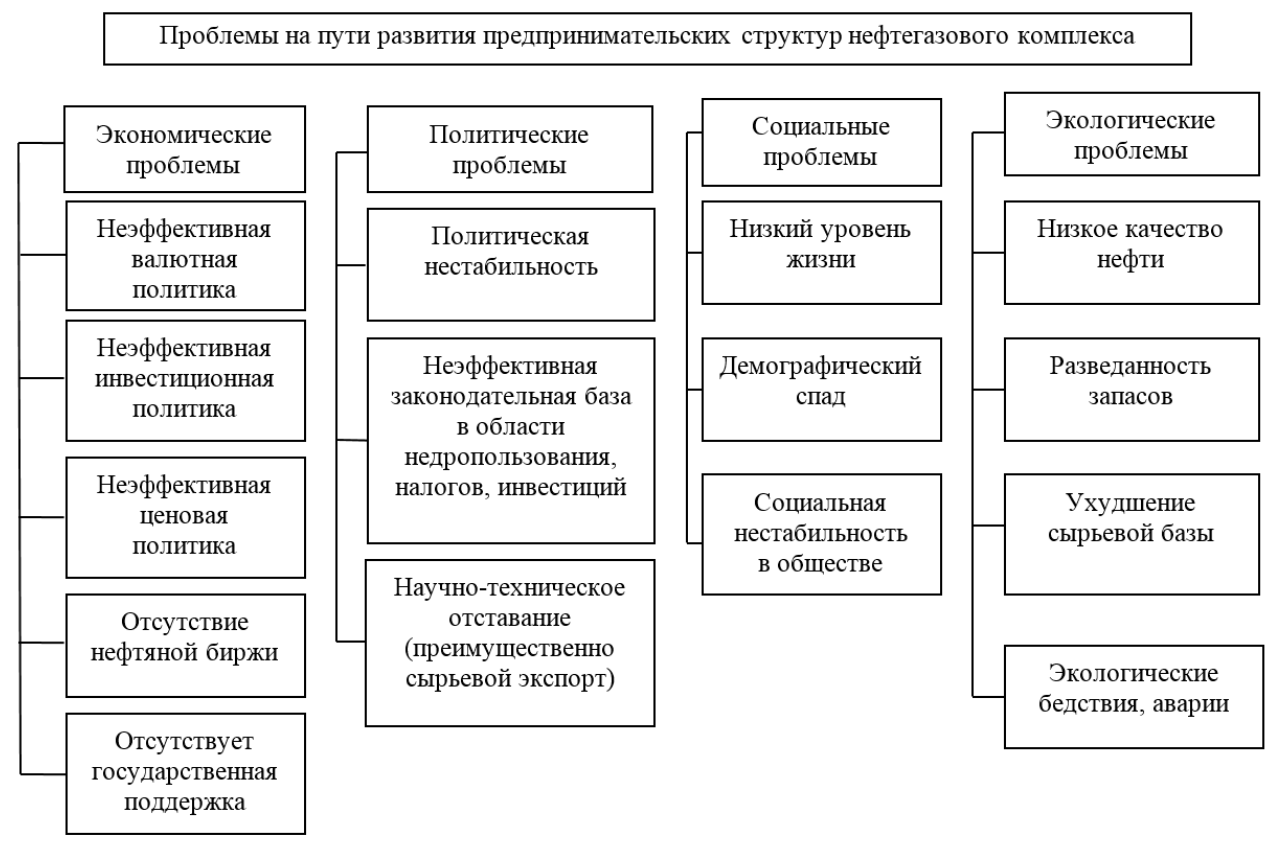

Рис. 11. Группировка проблем развития предпринимательских структур НГК по направлениям

Для решения большинства выделенных проблем современные предпринимательские структуры выстраивают свою деятельность на принципах кооперации, объединяя свои усилия под администрированием одного юридического лица и формируя холдинговые предпринимательские структуры.

В исследованиях классиков экономической теории, в частности экономики предпринимательства, дано определение понятия «холдинг» предприятие, независимо от его организационно-правовой формы, в состав активов которого входят контрольные пакеты акций других предприятий. Однако последние изменения в системе государственного управления, смена политических и экономических приоритетов в Российской Федерации, заявленных руководством страны на ближайшие 5-10 лет, определяют новые 
направления деятельности существующих крупных предприятий, заставляя их, порой в нарушение общей истории развития, активно внедрять и разумно использовать технологические и управленческие инновации.

Таким образом, мы сталкиваемся с переходным этапом развития холдингов, которые на современном этапе реформирования отечественной экономики преобразуются в холдинговые предпринимательские структуры.

Обобщая современную научно-исследовательскую литературу в исследовании, авторы выделили основные черты холдинга, которые переходят по праву преемственности к холдинговым предпринимательским структурам.

Процедуры перехода таких крупных субъектов рыночных отношений, как холдинги, на уровень холдинговых предпринимательских структур требует уточнения терминологии, связанной с новым этапом развития производственных отношений для обеспечения рационального внедрения и реализации инноваций.

В данной работе под холдинговыми предпринимательскими структурами НГК понимается имущественный НГК, состоящий из объединенных в одно юридическое лицо двух и более предпринимательских структур, в котором перераспределение предпринимательского дохода, полученного от реализации внутриорганизационных инноваций, между множеством различных видов деятельности происходит на основании решения большинства учредителей (акционеров).

Проблемы развития холдинговых предпринимательских структур НГК имеют ряд отличительных особенностей. Они вызваны сложностями, с которыми столкнулись предпринимательские структуры НГК в период перераспределения прав недропользования. Сложности были инициированы приватизацией государственного имущества в XX в. и закончились лишь в новом тысячелетии. Современные предпринимательские структуры НГК имеют в своем составе активы различной географической принадлежности, организационные структуры подобных предпринимательских структур в составе группы не унифицированы, квалификация руководителей и исполнителей очень сильно колеблются и т. д.

Для повышения эффективности деятельности холдинговых предпринимательских структур необходимо оперативное решение указанных выше проблем, для чего требуется совершенствование методических подходов к управлению предпринимательским доходом. На современном рынке некогда единые предпринимательские структуры разделились на занимающиеся производством (добычей) и сервисом в НГК. Вследствие чего проявились недоработки в самих принципах управления взаимодействием холдинговой и сервисной предпринимательскими структурами НГК. Не определены методические подходы к управлению разрозненными взаимодействующими предпринимательскими структурами, деятельность которых была единой на ранних этапах жизненного цикла.

Таким образом, в настоящее время в развитии предпринимательских структур НГК страны существует ряд проблем, которые условно можно разделить на зависящие от внутренних и внешних причин. К внутренним причинам можно отнести состояние основных производственных фондов (ОПФ), их значительный физический износ, высокую себестоимость 
продукции, а также неспособность компаний возобновлять сырьевую базу и сокращение геолого-разведочных работ, что явилось следствием дефицита инвестиционных ресурсов. Таким образом, наращивание инвестиций существенный вопрос экономики страны и ее населения.

В то же время развитие НГК в значительной степени будет зависеть от ситуации на мировых энергетических рынках, инвестиционной привлекательности России, налоговой политики, законодательной базы в области недропользования, даже от сложившейся на сегодняшний момент демографической картины страны. Крупнейшей нерешенной проблемой является научно-техническое отставание предпринимательских структур НГК (преимущественно сырьевой экспорт). Поэтому для предотвращения больших рисков развития НГК должны быть созданы механизмы активного регулирования экономических процессов с целью обеспечения государственных интересов в предстоящем периоде при сохранении условий для развития и совершенствования предпринимательских структур множества его отраслей.

По характеру функционирования и системы управления принадлежащими им дочерними предприятиями холдинговые предпринимательские структуры НГК являются материнскими.

Несмотря на кажущуюся простоту понятия «холдинг», многие специалисты трактуют его по-разному.

Некоторые специалисты утверждают, что «холдинговые компании являются разновидностью предпринимательских объединений, под которыми мы понимаем все возможные формы объединения коммерческих организаций, создаваемые ими $[70,71]$ как добровольно (на договорной основе), так и принудительно, в результате подчинения и контроля одного юридического лица над другими, для осуществления согласованной предпринимательской деятельности».

Выделим основные существенные черты современного холдинга: 1) предприятия, входящие в холдинг, экономически взаимосвязаны между собой и имеют единый финансово-хозяйственный механизм; 2) группа предприятий не является единым плательщиком налогов и не имеет отдельных собственных органов управления; 3) группа предприятий не является самостоятельным участником гражданского оборота, юридическим лицом, организационно-правовой формой; 4) основой взаимосвязи предприятий группы являются участие головной организации в деятельности дочерних, зависимых предприятий и возможность осуществления контроля над их деятельностью через собрание акционеров; 5) любые действия, предпринимаемые группой предприятий, осуществляются через участников, которые являются юридически самостоятельными субъектами.

В Гражданском кодексе Российской Федерации отсутствует определение понятия «холдинг», но существуют такие понятия, как «дочернее общество» и «основное общество».

1. Хозяйственное общество признается дочерним, если другое (основное) хозяйственное общество или товарищество в силу преобладающего участия в его уставном капитале, либо в соответствии с заключенным между ними договором, либо иным образом имеет возможность определять решения, принимаемые таким обществом. 
2. Дочернее общество не отвечает по долгам основного общества (товарищества).

Основное общество (товарищество), которое имеет право давать дочернему обществу, в том числе по договору с ним, обязательные для него указания, отвечает солидарно с дочерним обществом по сделкам, заключенным последним во исполнение таких указаний.

В случае несостоятельности (банкротства) дочернего общества по вине основного общества (товарищества) последнее несет субсидиарную ответственность по его долгам.

3. Участники (акционеры) дочернего общества вправе требовать возмещения основным обществом (товариществом) убытков, причиненных по его вине дочернему обществу, если иное не установлено законами о хозяйственных обществах.

Современная классификация холдингов представлена на рис. 12 [70, 71].

Выделяют следующие группы холдингов:

1. По признаку участия государства в капитале участников:

a) государственные;

б) частично государственные;

в) холдинги, без участия государства.

2. В зависимости организационно-правовой формы:

a) закрытое акционерное общество;

б) открытое акционерное общество.

3. По признаку участия имущества в перераспределении ресурсов:

a) имущественный - вид холдинга, в котором материнская компания владеет контрольным пакетом акций дочерней компании;

б) договорной - вид холдинга, в котором у головной компании нет контрольного пакета акций дочернего предприятия, a контроль осуществляется на основании заключенного между ними договора.

Чистый холдинг - вид холдинга, в котором головная компания владеет контрольными пакетами акций дочерних предприятий, но сама не ведет никакой производственной деятельности, а выполняет только контрольно-управленческие функции.

Смешанный холдинг - вид холдинга, в котором головная компания ведет хозяйственную деятельность, производит продукцию, оказывает услуги, но при этом выполняет и управленческие функции по отношению к дочерним предприятиям.

Интегрированный холдинг - вид холдинга, в котором предприятия связаны технологической цепочкой. Данный тип получил широкое распространение в НГК, где под руководством головной компании объединены предприятия по добыче, транспортировке, переработке и сбыту продукции.

Конгломератный холдинг объединяет разнородные предприятия, не связанные технологическим процессом. Каждое из дочерних предприятий ведет свой бизнес, ни в коей мере не зависящий от других «дочек».

Классический холдинг — вид холдинга, в котором головная компания контролирует дочерние фирмы в силу своего преобладающего участия в их уставном капитале. Дочерние предприятия, как правило, не владеют акциями головной компании, хотя абсолютно исключить такую возможность нельзя. В ряде случаев они имеют мелкие пакеты акций материнской компании. 


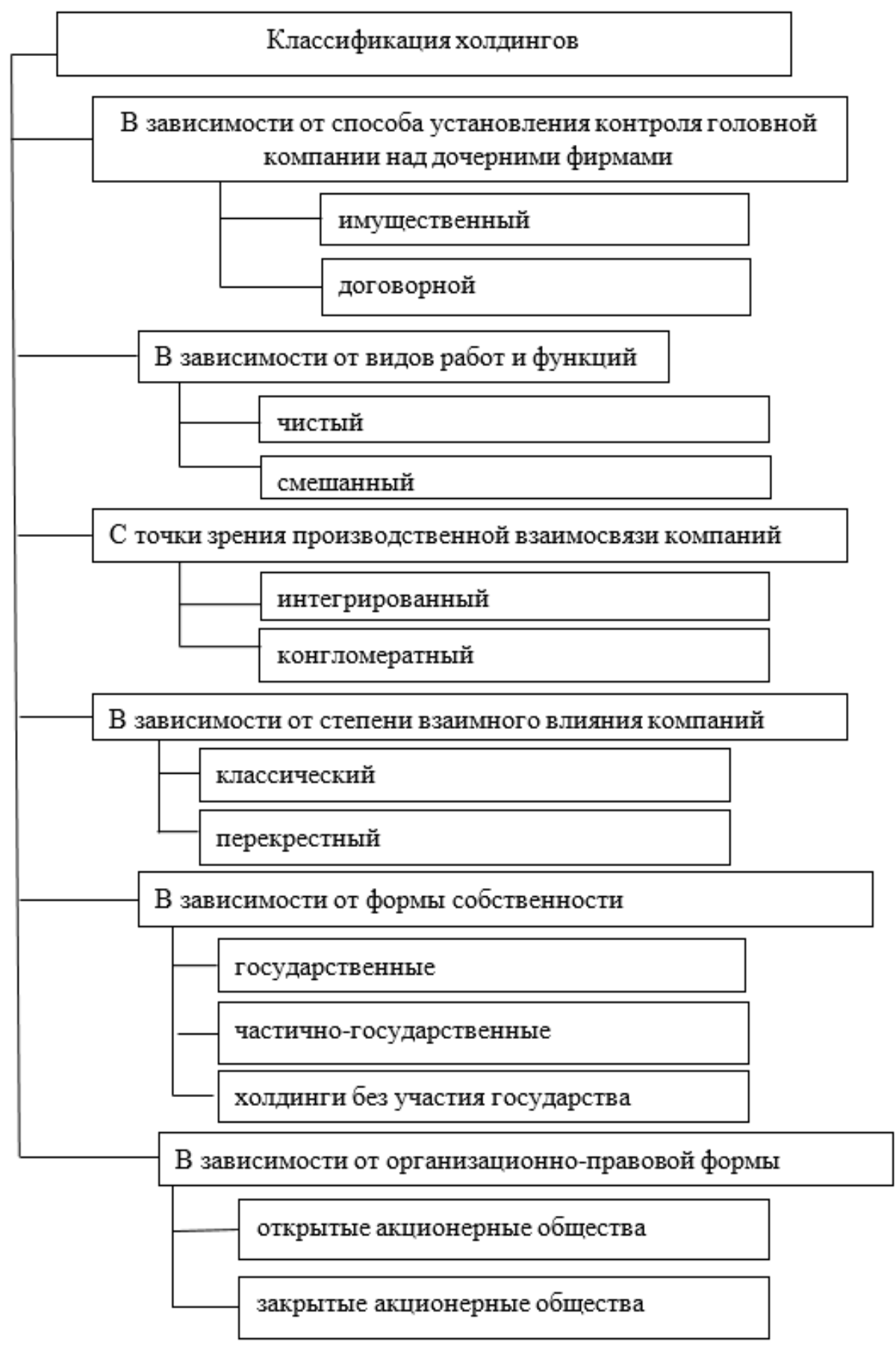

Рис. 12. Классификация холдинговых предпринимательских структур 
Перекрестный холдинг - вид холдинга, при котором предприятия владеют контрольными пакетами акций друг друга. Такая форма холдингов характерна для Японии, где банк владеет контрольным пакетом акций предприятия, а оно обладает контрольным пакетом акций банка. Таким образом, происходит сращивание финансового и промышленного капиталов, что, с одной стороны, облегчает предприятию доступ к финансовым ресурсам, имеющимся у банка, а с другой стороны, дает банкам возможность полностью контролировать деятельность дочерних фирм, предоставляя им кредиты.

Проблемы развития холдинговых предпринимательских структур в НГК имеют ряд отличительных особенностей от других предпринимательских структур. Выделим основные проблемы развития холдинговых предпринимательских структур: сложность управления в целом; «засоренность» активов; усложненная организационнотехнологическая структура; размытость четких границ основной технологической цепочки осуществления предпринимательской деятельности; зависимость от обеспеченности ресурсами основной и вспомогательной деятельности предпринимательских структур, входящих в холдинг; зависимость эффективности деятельности предпринимательских структур от внешнеполитических связей и макроэкономических показателей в мире; зависимость эффективности деятельности от качества природных ресурсов; сложность планирования деятельности; недостаточная законодательная база в области предпринимательских структур холдингового типа; дублирование управленческих функций материнской и дочерней предпринимательских структур; недостаточная изученность финансовых и прочих отношений внутри холдинговой предпринимательской структуры; снижение ответственности, входящих в холдинг предпринимательских структур; усложнение структуры, порядка, динамики движения финансовых потоков внутри холдинговой предпринимательской структуры; снижение конкуренции, входящих в холдинг предпринимательских структур; необходимость постоянного контроля результатов и координации деятельности подразделений холдинговой предпринимательской структуры; опасность увеличения затрат и т. д.

Для повышения эффективности деятельности холдинговых предпринимательских структур в целом и входящих в них сервисных и дочерних предпринимательских структур необходимо скорейшее решение указанных выше вопросов, для чего требуется совершенствование системы управления предпринимательским доходом.

Нефтегазовый комплекс включает в себя НГДПС и СП, основным направлением деятельности которых является оказание услуг, специфических для нефтегазового сектора. Взаимная интеграция сервисных и нефтеперерабатывающих предпринимательских структур в хозяйственную деятельность друг друга базируется на обслуживании потребностей предприятий нефтегазового сектора.

Основные услуги в сфере нефтяного сервиса представлены на рис. 13.

Сервисный сектор предпринимательской деятельности НГК, предоставляющий различные услуги производственного и непроизводственного характера, имеет значение, так как: повышает 
экономическую эффективность процессов поиска, разведки, освоения и разработки месторождений углеводородного сырья; формирует дополнительные рабочие места; увеличивает в структуре занятых удельный вес представителей наиболее современных профессий (оказывая тем самым влияние на динамику доходов населения); способствует формированию и реализации мультипликативных эффектов в экономике региона, где реализуются нефтегазовые проекты.

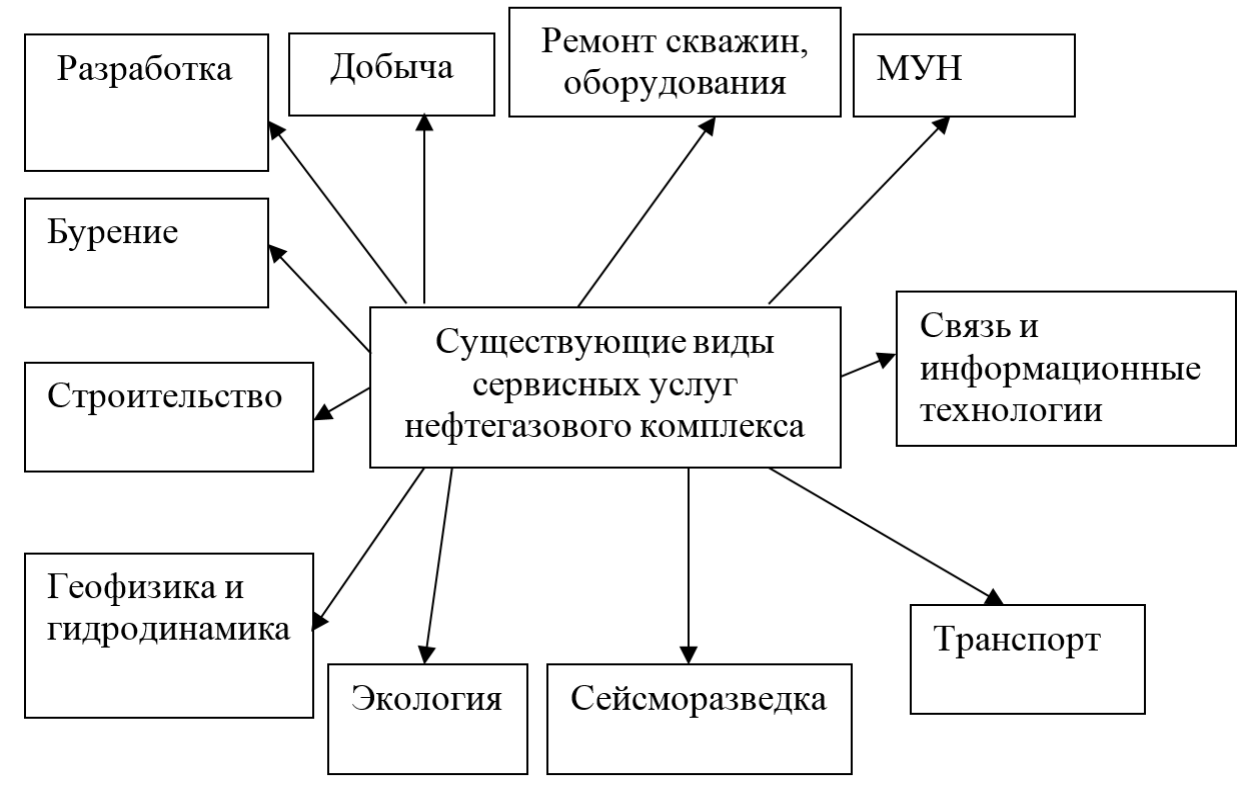

Рис. 13. Существующие виды сервисных услуг предпринимательских структур НГК

По разным оценкам, сегодня в России работают от двухсот до трехсот сервисных предпринимательских структур $[6,8]$. Объём услуг на рынке нефтесервиса предпринимательских структур в 2008 г. оценивался в 15 млрд долл. США [26]. Из этого объёма около $52 \%$ приходится на долю подразделений нефтегазодобывающих компаний, $28 \%$ занимают независимые российские компании, доля иностранных компаний достигает $20 \%$ и ежегодно увеличивается (рис. 14) [4].

O перспективах доминирования предпринимательских структур с участием иностранного капитала на российском нефтесервисном рынке суждения экспертов разделяются. Ключевая позиция в том, что на данный момент по финансовым и кадровым ресурсам ни одна из российских сервисных предпринимательских структур не может конкурировать с транснациональными оригиналами. Увеличивая долю на сервисном рынке России, западные предпринимательские структуры в дальнейшем смогут частично монополизировать нефтесервисный рынок и постепенно поднимать цены на свои услуги, приводя их к мировому уровню [10]. 


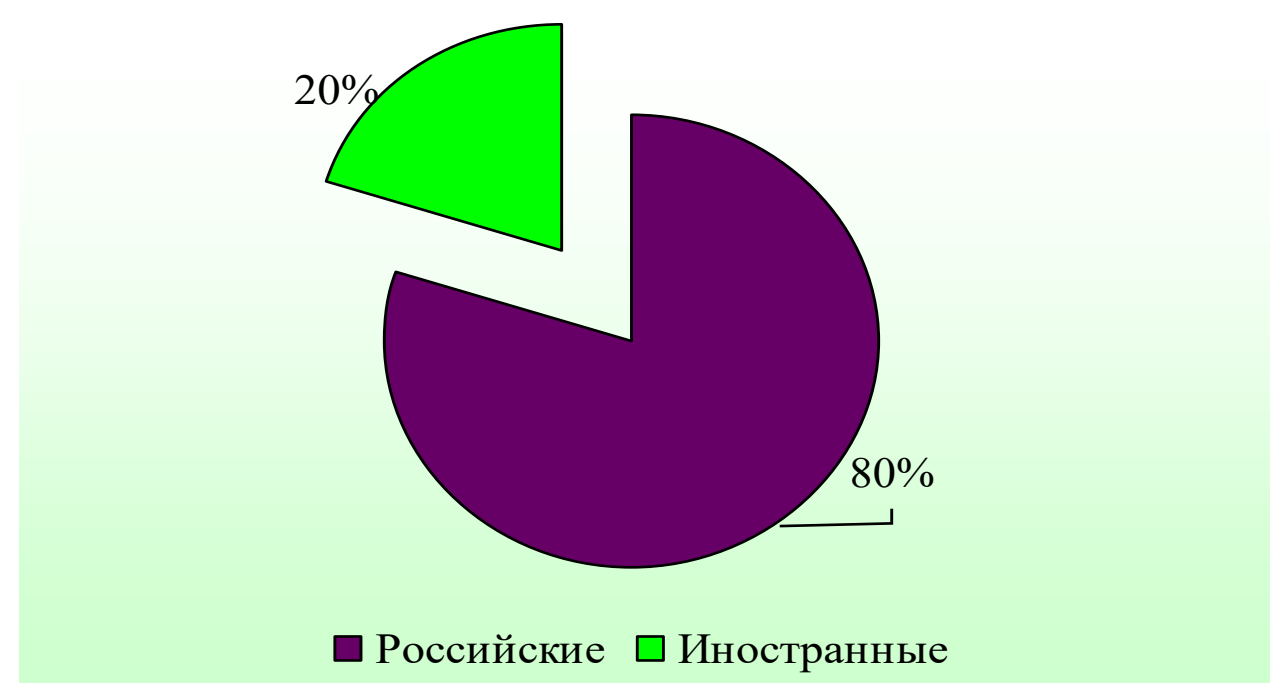

Рис. 14. Распределение объема российского рынка нефтесервисных услуг предпринимательских структур между российскими и иностранными предпринимательскими структурами

Противоположная точка зрения о том, что западные предпринимательские структуры не будут доминировать в России, основывается на следующем: 1) российский сервисный рынок специфичен: менталитет заказчика, российская инженерная школа, местные традиции с трудом учитываются западными предпринимательскими структурами, привыкшими к строгому выполнению своих обязательств; 2) машиностроительный комплекс России в последние годы интенсивно развивается, российское оборудование по качеству догоняет западное, что позволяет надеяться на внедрение инновационно активных технологий в сервисное обслуживание; 3) в России созданы уникальные технологии простые технические решения, адекватные по цене и качеству, но уступающие по одной из этих составляющих свойств конечной продукции; 4) ряд материалов и оборудования западные предпринимательские структуры начали производить в России, они используют при этом российские предприятия и создают новые рабочие места (к примеру, 95 \% сотрудников российского подразделения Schlumberger - pocсияне).

Согласно оценкам экспертов, большинство нефтяных предпринимательских структур выведут сервисные услуги на аутсорсинг. На процесс разделения добывающего и сервисного бизнесов уйдет, по различным оценкам, еще 5-7 лет, что и наблюдается в последние 2-3 года.

Прирост объемов добычи нефти в России сокращается: в начале 2000$\mathrm{x}$ гг. он составлял 7-10\% в год, на данный момент - 1,5-2,5\% в год. Увеличивать добычу углеводородов предпринимательских структур НГК можно двумя путями: разрабатывать новые месторождения и увеличивать извлечение нефти на уже эксплуатируемых объектах. Оба пути способствуют расширению сервисного рынка. 
Но запланированное наращивание объемов добычи нефти ключевыми крупными предпринимательскими структурами оказывается невозможным без серьезных инвестиций в геологоразведку, а также в обслуживание и поддерживание на необходимом уровне добычи действующих объектов недропользования. Вследствие данных процессов центр предпринимательского дохода смещается из сектора добычи в нефтегазовый сервис. Соответственно, для инвесторов все больший интерес представляют секторы рынка, обслуживающие НГК.

Например, рассмотрим инвестиционную политику ОАО «ЛУКОЙЛ». В 2015 г. из инвестиций, направленных на добычу и разведку (2918 млн долл. США), на нефтесервис было потрачено 32,0 \% (935 млн долл. США). В 2016 г. на сервис расходуется 33,2 \% средств (около 1700 из 5120 млн долл. США).

Возможно, именно данная тенденция - переток денежных средств из сырьевого сектора в машиностроение и нефтегазовый сервис - позволит российской экономике приобрести статус высокотехнологичной, а не сырьевой.

Обратимся к данным, опубликованным ОАО «ЛУКОЙЛ». Объём сервисных услуг по основным видам деятельности предпринимательской структуры составляет более 45 млрд руб. и ориентировочно выглядит следующим образом: строительство новых скважин - 18,2 млрд руб.; текущий и капитальный ремонт скважин - 8,5 млрд руб.; ремонт и обслуживание нефтепромыслового оборудования — 6,7 млрд руб.; энергообеспечение 6,7 млрд руб.; повышение нефтеотдачи пластов - 5,2 млрд руб.

Основными задачами предпринимательских структур по оказанию сервисных услуг отметим: повышение эффективности и технологичности услуг нефтесервисных предпринимательских структур; оптимизацию стоимости оказываемых услуг; обеспечение стабильности и динамичности производственной деятельности сервисных предпринимательских структур; развитие рыночной конкурентоспособной нефтесервисной предпринимательской структуры с современной системой управления.

\section{3. Условия эффективного взаимодействия структур в системе управления промышленных корпораций}

Конечным результатом эффективного взаимодействия сервисной и холдинговой предпринимательских структур является извлечение по результатам взаимодействия предпринимательского дохода, который характеризует, в свою очередь, эффективность внедрения и использования инноваций в производственных и управленческих отношениях.

Как отмечалось ранее, извлечение предпринимательского дохода как части прибыли, которая должна быть направлена на развитие взаимодействия, происходит через оценку конечного результата. Сложность оценки состоит в выделении доли инновационных решений в общей массе экономического эффекта.

Наиболее простым инструментом, позволяющим оценить уровень предпринимательского дохода в отношениях сервисная предпринимательская структура - холдинговая предпринимательская структура НГК, является прирост фондоотдачи от средств производства, переданных на сервисное обслуживание. 
В действительности, именно уменьшение сроков сервисных работ или повышение их качества наиболее полно отразятся на фондоотдаче конкретных средств производства холдинговых предпринимательских структур.

Процесс получения предпринимательского дохода сервисной предпринимательской структурой может быть реализован несколькими путями. Наиболее широко эти пути раскрываются через систему премирования сервисной предпринимательской структуры. В большинстве случаев речь идет о разовых платежах, которые разрешены руководством холдинговой предпринимательской структуры для расходования его подразделениями в случаях обнаружения непредвиденных обстоятельств.

Проблемами выступают отсутствие исследований возможностей по оптимизации работы со средствами производства в период их ремонта и отсутствие плановых величин резервирования средств для поощрения инноваций в сервисных работах.

Высшее руководство холдинговой предпринимательской структуры не имеет целей развивать отдельно инновационные потенциалы выделенной сервисной деятельности. Эта вспомогательная деятельность ложится в общую концепцию развития инноваций в производстве нефтегазовых предпринимательских структур.

Однако именно эта деятельность все чаще реализуется не через собственные подразделения, a передается на сторону внешнего обслуживания. В лучшем случае эти отношения носят характер аутсорсинга, но в большинстве примеров подбор исполнителей для выполнения сервисных работ на текущий и плановый ремонты происходит путем проведения конкурсов. То есть в сервисной деятельности очень вероятны такие отношения между сервисными и холдинговыми предпринимательскими структурами, в которых результат взаимодействия дискретен и не может быть проанализирован в результате постоянной смены исполнителей работ.

Таким образом, для формирования эффективного взаимодействия сервисных и холдинговых предпринимательских структур НГК необходимо соблюдать ряд требований к построению взаимодействия для наиболее полного извлечения предпринимательского дохода, который выплачивается в виде премий (рис. 15).

Следует обратить внимание на то, что мы не говорим о постоянном ухудшении качества работ, речь идет лишь о разных подходах к их организации.

Ключевыми принципами, которыми определяются требования к премированию эффективности и построению партнерских отношений для формирования прозрачности процесса извлечения предпринимательского дохода, являются.

1. Принцип измеримости результатов, который предопределяет необходимость формирования в ходе выполнения работ отчетных, контрольных точек, по которым возможно сравнение хода выполнения работ на различных объектах.

2. Принцип единообразия отчетности, который определяет необходимость разработки единых требований ко всем участникам, относящимся к сервисной деятельности. Речь идет о построении единой нормативной базы внутри холдинговой предпринимательской структуры, позволяющей сравнивать результаты. 


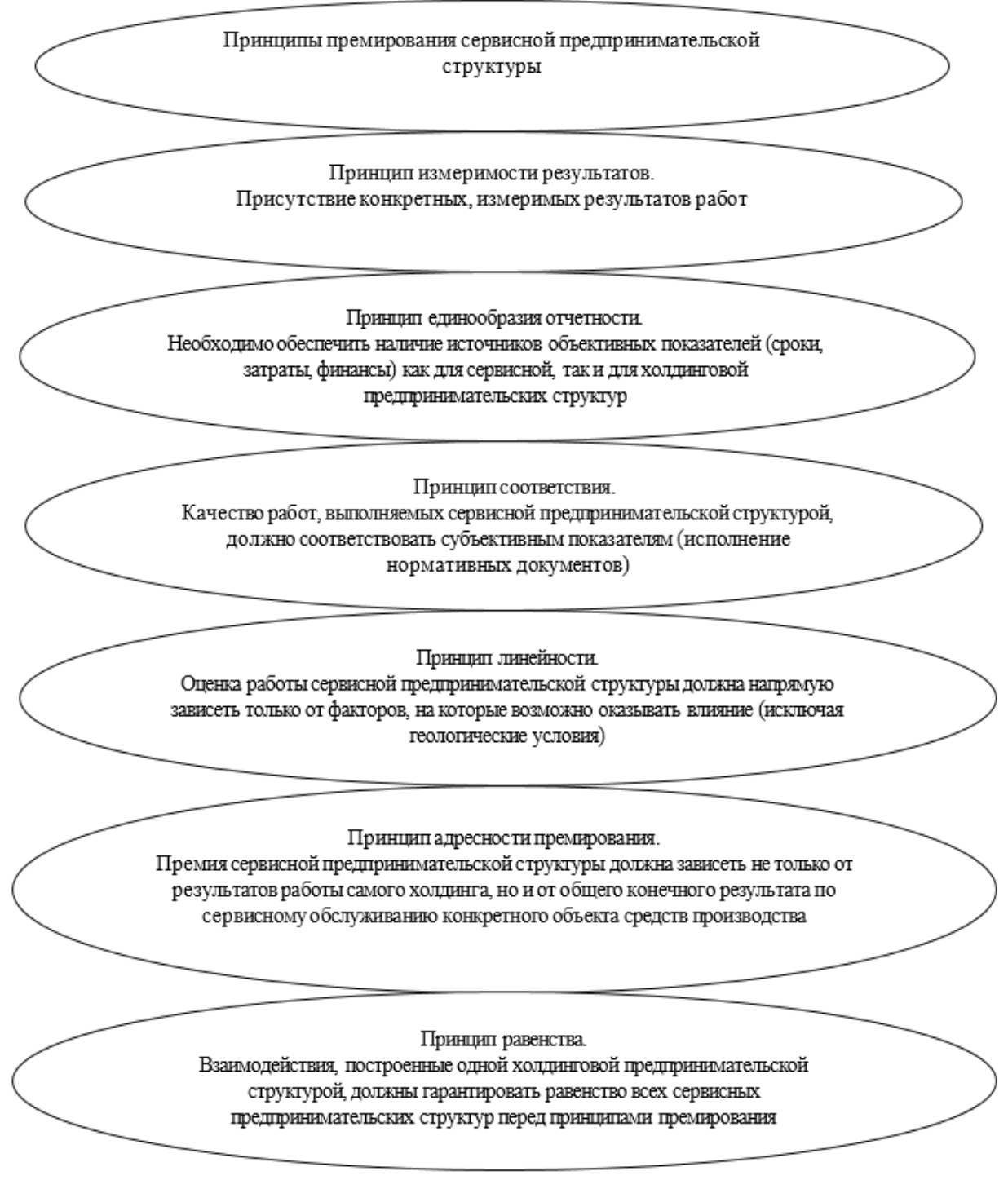

Рис. 15. Принципы премирования сервисной предпринимательской структурой и различными предпринимательскими структурами

3. Принцип равенства. Для реализации инноваций в отношениях сервиса для НГК должны быть реализованы требования равенства возможности участия в работах новых и уже работающих предпринимательских структур. Это позволит новым, зачастую малым, предпринимательским структурам реализовать задуманные инновации.

Важным условием является возможность измерения показателей, которые изменяются вслед за внедрением инноваций. Методические положения по сглаживанию асимметрии предусматривают последовательное развитие партнерских отношений предпринимательских структур по этапам (рис. 16). 


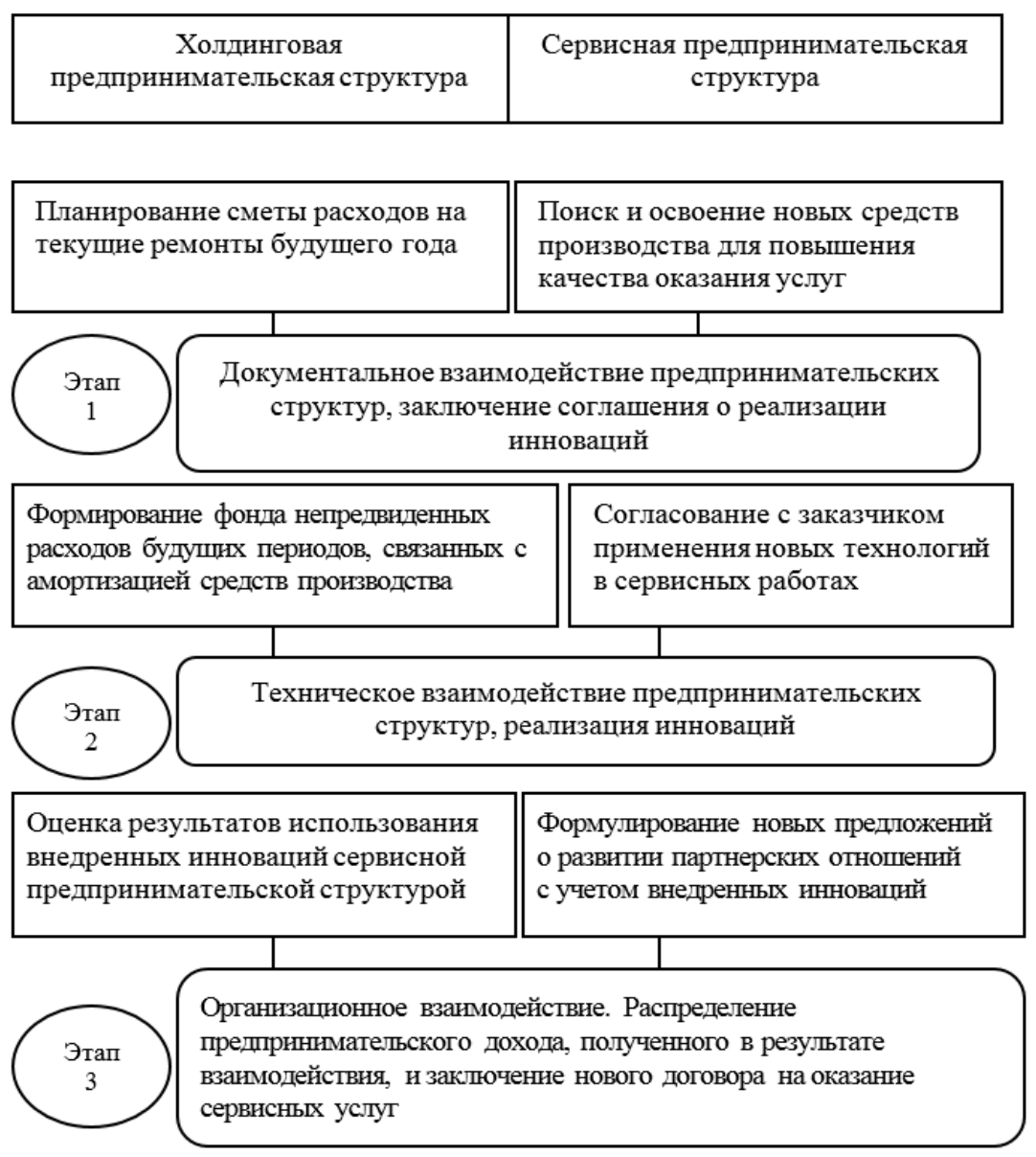

Рис. 16. Методические рекомендации по сглаживанию управленческих противоречий в процессах формирования и распределения предпринимательского дохода

Так, решение проблем, связанных с асимметрией условий и задач выполнения сервисных услуг, может быть реализовано через дополнительные соглашения между сервисными предпринимательскими структурами и предпринимательскими структурами холдингового типа, выступающими заказчиками, определяющие премирование за применение инновационных решений, которые способствовали более качественному и скорому выполнению работ.

1. Документальное взаимодействие. На данном этапе построения взаимодействия сервисной и холдинговой предпринимательских структур происходит подписание соглашения о возможности реализации инновационной деятельности в ходе оказания сервисных услуг. Определяются перспективные результаты этой деятельности.

2. Техническое взаимодействие. На данном этапе происходит согласованное применение инноваций, позволяющее повысить фондоотдачу основного производства холдинговой предпринимательской структуры. 
3. Организационное взаимодействие. На данном этапе происходит перераспределение полученного предпринимательского дохода в соответствии с приростом фондоотдачи средств производства. Сумма предпринимательского дохода, подлежащая распределению, не может превышать лимит фонда непредвиденных расходов будущих периодов холдинговой предпринимательской структуры, связанных с амортизацией средств производства. Лимит определяется по прогнозам технологического взаимодействия.

При анализе современного опыта работы холдинговых предпринимательских структур со своими партнерами наблюдается преобладание формального подхода над экономическими интересами отдельных подразделений и бизнеса в целом.

Конкурсная форма отбора стратегических партнеров, а именно такими являются предпринимательские структуры, поддерживающие работоспособность основных фондов, не всегда является эффективной. Можно смело утверждать, что на современном рынке услуг нефтегазового сектора набор работ и качество их исполнения приобрели уже стабильные свойства и выполняются в рамках ожидаемых норм. Однако это не значит, что предпринимательской структуре - заказчику следует оставить без внимания необходимость оценки качества произведенных работ.

С другой стороны, рынок технологических и управленческих инноваций настолько широк, что на нем можно при активном поиске найти нетрадиционные решения устоявшихся, на первый взгляд, задач. Одним из таких решений является применение отношений аутсорсинга для построения системы обслуживания скважин и других средств производства холдинговых предпринимательских структур.

Эта форма построения партнерских отношений подразумевает взаимодействие по многим каналам распределения информации, материальнотехнических запасов и финансовых средств. Аутсорсинг практически полностью вливается в деятельность холдинговой предпринимательской структуры, обеспечивая постоянное качество выполнения сервисных работ.

Этот подход дает возможность внедрить малое число инновационных решений. В первую очередь это связано с долгосрочностью соглашения о партнерстве и погружении предпринимательской структуры - аутсорсера в особенности ведения деятельности холдинговой предпринимательской структуры. Ожидаемые инновации могут иметь место на первом этапе формирования отношений сотрудничества, тогда как сами взаимодействия становятся стабильными и невосприимчивыми к внедрению чего-то нового в перспективе.

Зрительный эффект от инноваций широко представлен конкурсной организацией отбора партнеров для оказания сервисных работ. Но, как отмечалось ранее, эффект имеет свои особенности, привязывающие холдинговую предпринимательскую структуру к взаимодействию именно с одним партнером, что опять же со временем ведет к потере интереса к внедрению инновационных решений либо к постоянной смене исполнителей работ, которая, в свою очередь, ведет к постоянным изменениям в возможностях использования средств производства холдинговой предпринимательской структуры. 
На наш взгляд, наиболее полным с точки зрения предпринимательского подхода является осуществление поисковой предпринимательской деятельности холдинговой предпринимательской структурой в направлении подбора наиболее передовых решений по осуществлению сервисных работ. Информация о новых идеях и готовых инновациях должна поступать в руки руководителей предпринимательской структуры - заказчика до осуществления конкурсного отбора.

Таким образом, схематично мы можем представить способы организации взаимодействия сервисных и холдинговых предпринимательских структур с позиции возможностей и достаточности реализуемых инноваций (рис. 17-19).

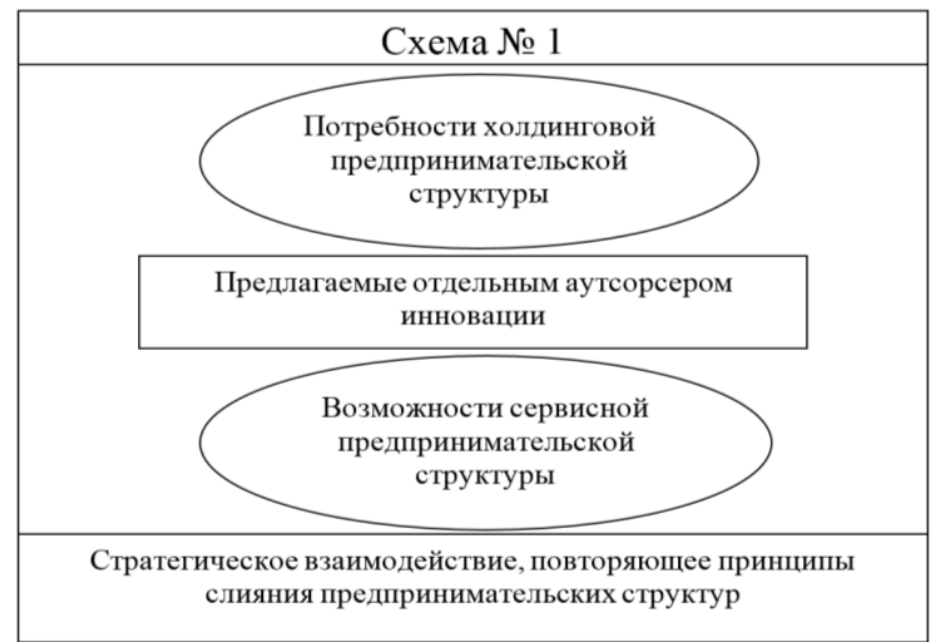

Рис. 17. Передача сервисных услуг в отношения аутсорсинга, реализация инноваций отдельного аутсорсера

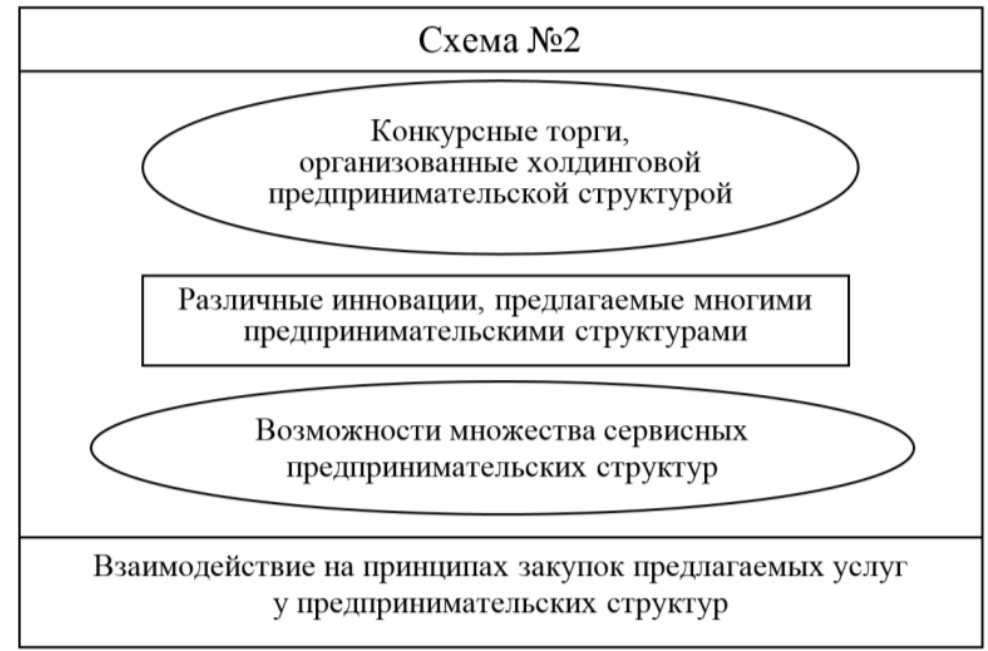

Рис. 18. Приобретение сервисных услуг на свободном рынке, реализация множества несвязанных инноваций 


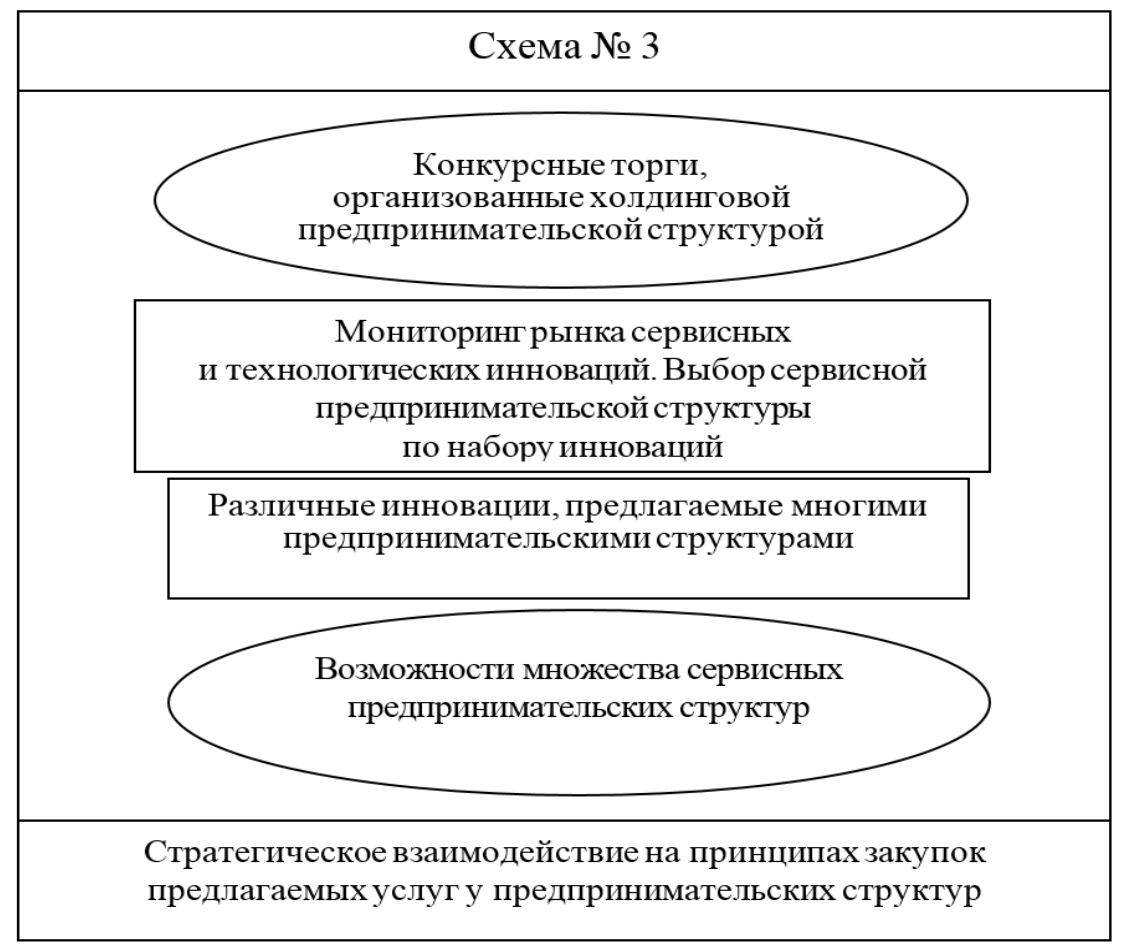

Рис. 19. Приобретение сервисных услуг на свободном рынке на основе отобранных инноваций, реализация множества связанных инноваций

Рисунок 17 иллюстрирует ситуацию, когда инновации носят ограниченный характер в рамках строгого взаимодействия одной сервисной и одной холдинговой предпринимательских структур.

Рисунок 18 показывает возможности по внедрению инноваций различного характера при условии выигрыша на торгах предпринимательской структуры с наилучшим соотношением цена / качество.

Зачастую выбор сервисной предпринимательской структуры на этих принципах не является полностью целесообразным, а сам отбор происходит по поверхностной информации. Таким образом, сама возможность внедрения инноваций ставится под большой вопрос.

Последняя схема (рис. 19) иллюстрирует возможности по организации обоснованного выбора необходимых инноваций холдинговой предпринимательской структурой. Этот подход требует организационных нововведений в деятельности холдинговой предпринимательской структуры, которые могут представлять собой дополнительную расходную часть, для проведения регулярного исследования рынка инноваций и мониторинга предложения сервисных предпринимательских структур.

\section{4. Принципы и методы формирования дохода предпринимательских структур}

Управление экономическими процессами в структуре любой отрасли зависит от соответствия системы управления потоками денежных средств 
конкретным сложившимся условиям. Осуществление практически всех видов финансовых операций предприятия генерирует определенное движение денежных средств и их эквивалентов в форме их поступления или расходования.

Важность оптимизации управления финансовыми потоками предприятия определяется следующими основными положениями [56].

1. Потоки денежных средств осуществляют обслуживание хозяйственной деятельности предприятия практически во всех ее аспектах. Образно их можно представить как систему финансового «кровообращения» хозяйственного организма предприятия. Оптимально организованные потоки являются важнейшим симптомом его финансового «здоровья», предпосылкой достижения высоких конечных результатов хозяйственной деятельности предпринимательской структуры в целом.

Оптимальное управление потоками денежных средств обеспечивает финансовое равновесие предприятия в процессе его стратегического развития. Темпы этого развития, финансовая устойчивость субъекта предпринимательства в значительной мере определяются тем, насколько различные виды потоков синхронизированы между собой по объемам и во времени. Высочайший уровень такой синхронизации обеспечивает существенное ускорение реализации стратегических целей развития предпринимательских структур [56].

2. Рациональное формирование денежных потоков способствует повышению ритмичности осуществления операционного процесса предприятия. Любой сбой в осуществлении платежей отрицательно сказывается на формировании производственных запасов сырья и материалов, уровне производительности труда, реализации готовой продукции и т. д. В то же время оптимально организованные потоки денежных средств предпринимательской структуры, повышая ритмичность осуществления операционного процесса, обеспечивают рост объема производства и реализации его продукции.

3. Оптимальное управление потоками денежных средств позволяет сократить потребность предприятия в заемном капитале. Активно управляя финансовыми потоками, можно обеспечить более рациональное и экономное использование собственных финансовых ресурсов, формируемых из внутренних источников, снизить зависимость темпов развития предприятия от привлекаемых кредитов. Особую актуальность этот аспект управления приобретает для предприятий, находящихся на ранних стадиях своего жизненного цикла, когда доступ к внешним источникам финансирования ограничен.

4. Оптимальное управление денежными потоками является важным фактором финансового обеспечения ускорения оборачиваемости капитала предприятия. Этому способствует сокращение продолжительности производственного и финансового циклов, достигаемое в процессе результативного управления финансовыми потоками, а также снижение потребности в капитале, обслуживающем хозяйственную деятельность предприятия. Ускоряя оборот капитала за счет оптимального управления финансовыми потоками, предприятие обеспечивает рост суммы генерируемой во времени прибыли. 
5. Оптимальное управление потоками денежных средств обеспечивает снижение риска неплатежеспособности предприятия. Даже у предприятий, успешно осуществляющих хозяйственную деятельность и генерирующих достаточную сумму прибыли, неплатежеспособность может возникать как следствие несбалансированности различных видов финансовых потоков во времени. Синхронизация поступлений и выплат денежных средств, достигаемая в процессе управления финансовыми потоками предприятия, позволяет установить фактор возникновения его неплатежеспособности.

6. Активные формы управления денежными потоками позволяют предприятию получать дополнительную прибыль, генерируемую непосредственно его финансовыми активами. Речь идет в первую очередь об эффективном использовании временно свободных остатков денежных средств в составе оборотных активов, а также накапливаемых инвестиционных ресурсов в осуществлении финансовых инвестиций. Высокий уровень синхронизации по объему и времени поступлений и выплат денежных средств позволяет снижать реальную потребность предприятия в текущем и страховом остатках денежных средств, обслуживающих операционный процесс [3].

7. Понятие предпринимательского дохода предприятия является агрегированным, включающим в свой состав многочисленные виды финансовых потоков, связанных с основной и финансовой деятельностью предпринимательских структур, а также с реализацией инноваций.

Различные теоретические взгляды классиков предпринимательства и современных ученых сформировали три ключевых подхода к пониманию предпринимательского дохода (рис. 20).

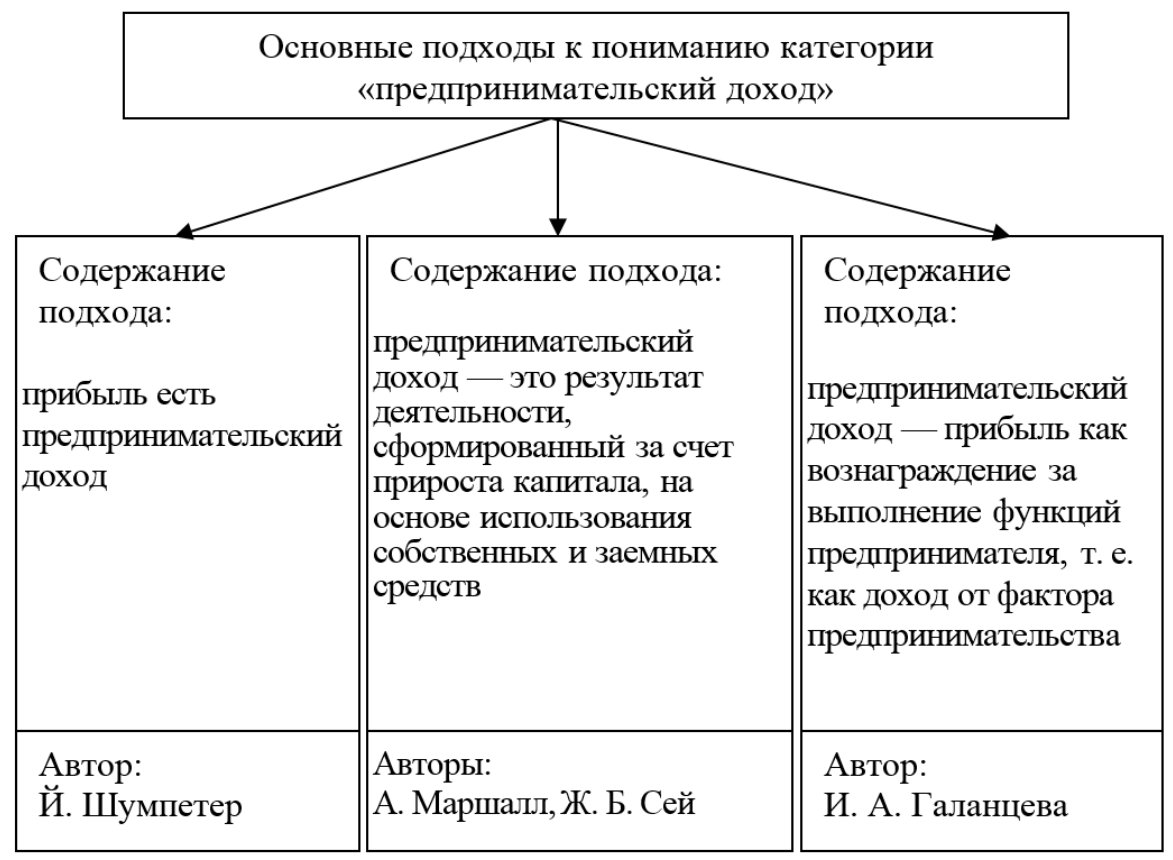

Рис. 20. Основные подходы к пониманию категории «предпринимательский доход» 


\section{Трактовки предпринимательского дохода}

Несмотря на множество трактовок предпринимательского дохода, можно выделить временную - экономическую - тенденцию, которая нашла свое отражение в теории предпринимательства. С усложнением технологического процесса и появлением новых финансовых и организационных инструментов ведения бизнеса предпринимательский доход все более четко отделяется от общей прибыли предпринимательской структуры.

Для реализации цели нашего исследования мы предлагаем уточнить понятие предпринимательского дохода. Под предпринимательским доходом следует понимать, на наш взгляд, прежде всего дополнительный доход, доход от управления, излитек, получаемый предпринимательской структурой благодаря особому подходу $\kappa$ анализу и комбинированию факторов производства при реализации инноваџионной деятельности в зависимости от внешних условий.

Данный подход, позволяет четко очертить границы понятия предпринимательского дохода, разделить текущую деятельность предпринимательской структуры и ее инновационную составляющую.

При характеристике деятельности холдинговой предпринимательской структуры в ее взаимодействии с сервисной следует выделить условия появления предпринимательского дохода, который имеет место на разных стадиях развития отношений и формируется за счет различных элементов (рис. 21).

В зависимости от соотношения объемов положительного и отрицательного денежных потоков сумма предпринимательского дохода может характеризоваться как положительной, так и отрицательной величинами, определяющими конечный результат от основной и инновационной хозяйственной деятельности предпринимательской структуры.

По уровню достаточности объема мы выделяем следующие виды предпринимательского дохода.

1. Избыточный предпринимательский доход, при котором поступления денежных средств от реализации инновационных решений существенно превышают реальную потребность предпринимательской структуры в целенаправленном развитии, связанном с освоением инноваций. Свидетельством такого дохода является высокая положительная величина чистого денежного потока, не используемого в процессе осуществления инновационной деятельности предпринимательской структуры.

2. Дефицитный предпринимательский доход, при котором поступления денежных средств от реализации инновационной деятельности предпринимательской структуры существенно снижают возможности удовлетворения потребностей в целенаправленном расходовании общей массы поступивших средств для развития новых направлений деятельности. Даже при положительной величине суммы предпринимательского дохода он может характеризоваться как дефицитный, если эта сумма не обеспечивает плановую потребность в расходовании денежных средств на возобновление деятельности по формированию инновационных решений. Отрицательное же значение предпринимательского дохода автоматически делает этот доход дефицитным. 


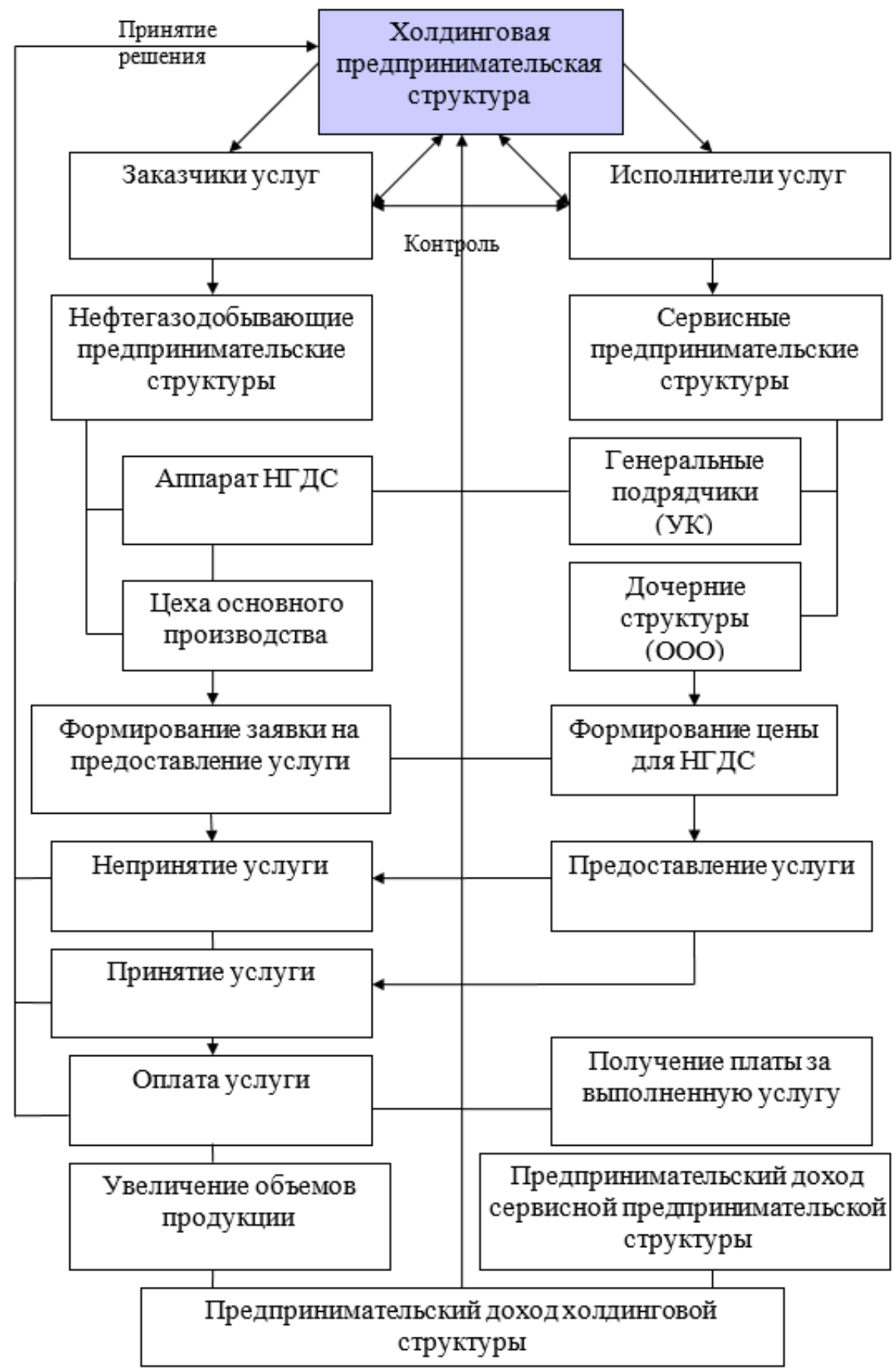

Рис. 21. Условия формирования предпринимательского дохода взаимодействующих холдинговой и сервисной предпринимательских структур

По методу оценки по времени определяют следующие виды предпринимательского дохода: настоящий предпринимательский доход (характеризует доход предпринимательской структуры как единую сопоставимую величину, приведенную по стоимости к текущему моменту 
времени); будущий предпринимательский доход (характеризует доход предпринимательской структуры как единую сопоставимую величину, приведенную по стоимости к моменту полной реализации инновационного решения). Понятие «будущий предпринимательский доход» может использоваться и как номинальная величина в предстоящем моменте времени (или в разрезе предстоящего интервала будущего периода), который применяется для дисконтирования в целях приведения к настоящей стоимости.

По непрерывности формирования в рассматриваемом периоде различают следующие виды предпринимательского дохода.

1. Регулярный предпринимательский доход. Он характеризует поток поступления или расходования средств по хозяйственным операциям (денежным потокам одного вида) для реализации инновационной деятельности, который в рассматриваемом периоде времени осуществляется постоянно по отдельным интервалам инвестиционно-инновационного отрезка планового периода. Характер регулярного носит большая часть видов денежных потоков, генерируемых операционной деятельностью предпринимательской структуры: потоки, связанные с обслуживанием кредита на реализацию инноваций во всех его формах, денежные потоки, обеспечивающие реализацию долгосрочных реальных инвестиционноинновационных проектов и т. п.

2. Дискретный предпринимательский доход. Он характеризует поступление или расходование денежных средств, связанные c осуществлением единичных операций по реализации инноваций предпринимательской структурой в рассматриваемом периоде времени. Характер дискретного предпринимательского дохода носит одноразовое расходование денежных средств, связанное с приобретением предприятием целостного имущественного комплекса, покупкой лицензии франчайзинга, поступлением финансовых средств в порядке безвозмездной помощи и т. п. для реализации инноваций.

По стабильности временных интервалов формирования регулярные предпринимательские доходы могут быть: регулярными с равномерными временными интервалами в рамках рассматриваемого периода реализации инноваций (такой денежный поток поступления или расходования денежных средств носит характер аннуитета); регулярными с неравномерными временными интервалами в рамках рассматриваемого периода реализации инноваций (например, график лизинговых платежей за арендуемое имущество для реализации инноваций с согласованными сторонами неравномерными интервалами времени их осуществления на протяжении срока лизинга).

Представленная выше классификация систематизирует существующие знания о видах предпринимательского дохода и позволяет оптимально осуществлять их учет, анализ и планирование предпринимательской структурой, что в конечном счете приведет к повышению экономической эффективности основной деятельности.

Для исследования под управлением предпринимательским доходом мы будем понимать непрерывный процесс, связанный с реализацией инноваций предпринимательской структурой, который предполагает 
формирование самостоятельной системы управления высвобождаемыми финансовыми, материальными ресурсами, полученными в результате инвестиционно-инновационной деятельности предпринимательской структуры.

Анализ современной научной литературы показал, что обеспечение эффективности деятельности предпринимательских структур может быть достигнуто с учетом следующих основных принципов.

1. Принцип формирования достоверности. Как и каждый элемент управляющей системы, оптимизация управления предпринимательским доходом должна быть обеспечена необходимой информационной базой.

2. Принцип обеспечения сбалансированности. Управление предпринимательским доходом должно происходить в согласовании с общей массой поступлений предпринимательской структуры. Реализация этого принципа связана с оптимизацией финансовых и материальных потоков предпринимательской структуры в процессе управления ими.

3. Принцип обеспечения эффективности. Предпринимательский доход хозяйствующего субъекта характеризуются существенной неравномерностью поступления и расходования денежных средств в разрезе отдельных временных интервалов реализации инноваций, что приводит к формированию значительных объемов временно свободных денежных активов предпринимательской структуры.

4. Принцип обеспечения ликвидности. Высокая неравномерность отдельных видов предпринимательского дохода порождает временный дефицит денежных средств предпринимательской структуры, который отрицательно сказывается на уровне его платежеспособности.

В исследовании предлагается дополнение и раскрытие существующих принципов управления, учитывающих особенности взаимодействия холдинговых и сервисных предпринимательских структур НГК.

1. Принщии ориентации на основную иель. Общей целью для холдинговой и сервисной предпринимательских структур является удовлетворение потребностей подразделений нефтедобычи в ходе реализации общих инноваций. Своевременное и качественное реагирование холдинговой и сервисной предпринимательских структур необходимо для поддержания нормального технологического процесса, что увеличивает эффективность производственно-хозяйственной деятельности в ходе реализации инновационных решений.

2. Принции обеспечения системности взаимоотнотений холдинговой u сервисной предпринимательских структур. Для увеличения предпринимательского дохода как холдинговой, так и сервисной предпринимательских структур необходима разработка единой системы взаимоотношений между холдинговой структурой и сервисными предпринимательскими субъектами в ходе реализации инноваций. В связи с этим необходимо наличие единой службы управления внутренними и внешними предпринимательскими структурами сервиса, единой нормативно-правовой базы взаимоотношений с целью создания учета, мониторинга и контроля соответствия единой системе и единой стратегии развития всего НГК. 
3. Принцип недопущения соперничества интересов холдинговой u сервисной предпринимательских структур. Важным условием организационно-структурного развития холдинговой предпринимательской структуры является приоритет в защите интересов не только владельцев уставного капитала, акционеров, но и всех сервисных предпринимательских структур.

4. Принщип исключения дублирования. В холдинговых предпринимательских структурах часто возникает ситуация дублирования функций управления. Применение принципа исключения дублирования предусматривает постоянный анализ организационной структуры ПС с целью дальнейшего выявления дублирования управленческих функций и принятия инновационного решения.

5. Принщип консолидащии финансов. Отметим, что существование этого принципа является неоспоримым, хотя требует уточнения. Этот принцип предусматривает составление баланса, отчета о финансовых результатах и предпринимательском доходе. Высокая степень объединения активов, вплоть до их слияния, требует построения консолидированного баланса, который полностью включает балансы всех участников холдинговой предпринимательской структуры.

6. Принцип главенства. Данный принцип предусматривает главенствующее положение холдинговой структуры, но в то же время необходимость невмешательства в оперативное управление сервисными предприятиями в ходе реализации инноваций. Взаимозависимость производственного процесса и предпринимательского дохода, а также их влияние на конечную чистую прибыль холдинговой структуры НГК представлены на рис. 22, из которого видно, что на чистую прибыль предпринимательской структуры влияют три основополагающие составляющие: 1) производственная цепочка, которая состоит из разведки месторождений, бурения разведочных и эксплуатационных скважин, добычи нефти и газа и реализации нефти и нефтепродуктов; 2) уровень выручки, который зависит от производственного процесса, в том числе от качества разведочных мероприятий, эффективности бурения, объемов добываемой и реализуемой нефти и нефтепродуктов, а значит, от планирования, учета и контроля; 3) расходы нефтяной предпринимательской структуры во многом зависят от эффективности всех этапов производственного процесса, на которые оказывает влияние качественный процесс планирования производства, срочность и точность оказания сервисных услуг, а также уровень налоговых платежей.

В экономической и финансовой литературе выделяют три источника получения дохода по следующим видам деятельности: от основной деятельности; от инвестиционной деятельности; от финансовой деятельности.

В ходе исследования была раскрыта позиция формирования предпринимательского дохода. В графическом виде его формирование представлено на рис. 23. 


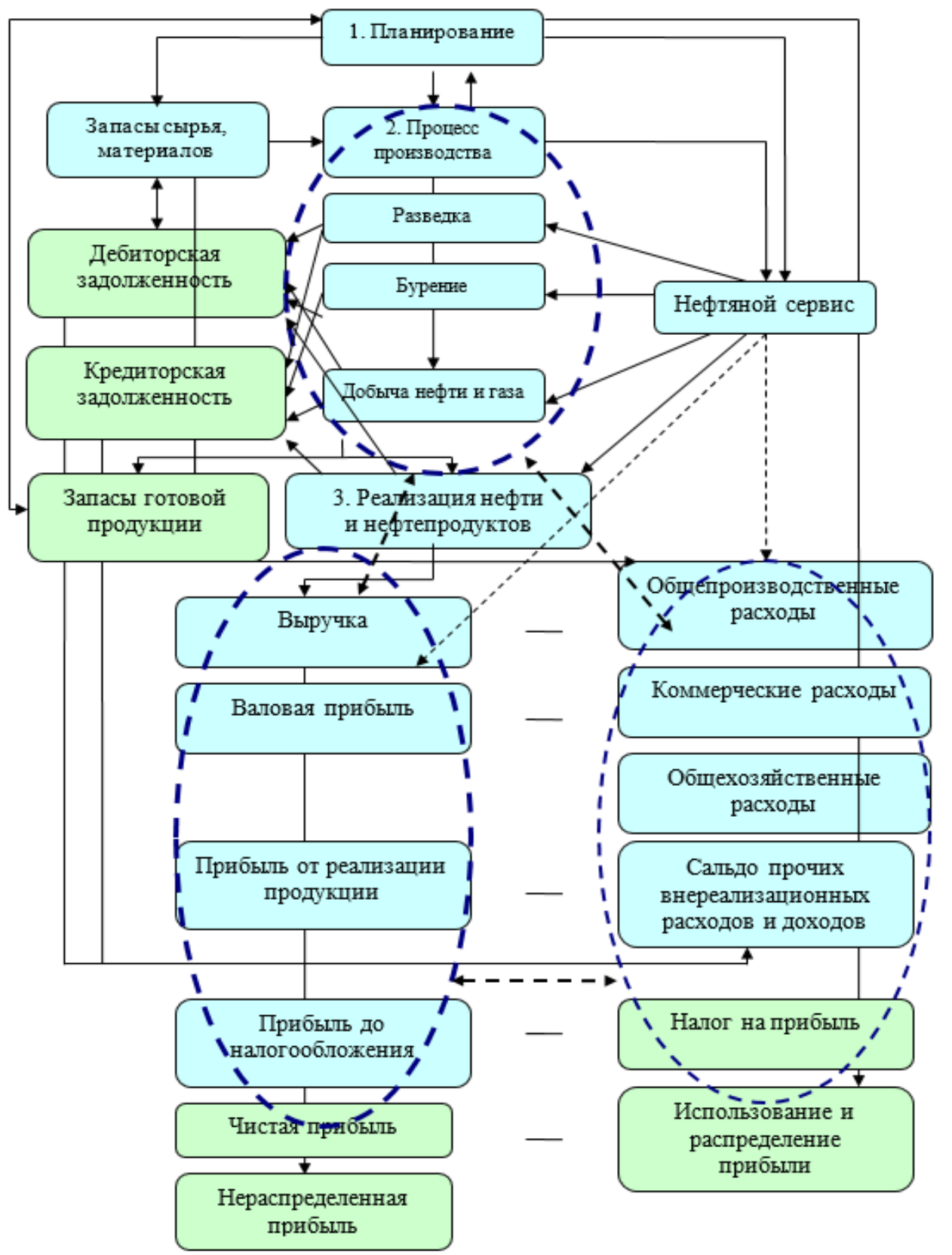

Рис. 22. Взаимозависимость производственного процесса и формирования предпринимательского дохода

Немаловажным является не только процесс формирования прибыли, но и процесс ее распределения, который представляет собой процесс формирования направлений ее использования в соответствии с основными целями и стратегическими и текущими задачами развития предприятия.

Высокая значимость распределения прибыли в деятельности предприятия определяется следующими положениями: 1) распределение 
прибыли помогает достижению главной цели предприятия, которая выражается в повышении уровня благосостояния его акционеров; 2) поскольку рост рыночной стоимости предприятия проявляется в обеспечении прироста капитала в процессе капитализации части распределенной прибыли, то распределение прибыли является основным инструментальным методом воздействия; 3) так как стратегия развития предприятия реализуется в процессе инвестиционной деятельности за счет внутренних и внешних источников, можно отметить, что реинвестируемая в процессе распределения прибыль является основным из внутренних источников; 4) возрастание уровня дивидендных выплат определяет рост стоимости акций на фондовом рынке, вследствие чего формируется дополнительный доход инвесторов и, следовательно, повышается инвестиционная привлекательность предприятия; 5) одной из функций прибыли является ее мотивационная составляющая, которая влияет на трудовую активность персонала предприятия и способствует росту производительности труда; 6) из теории формирования и распределения прибыли, выраженной в основных функциях, вытекает социальная функция, следовательно, качество распределения прибыли формирует уровень обеспечения дополнительной социальной защиты работников; 7) уровень текущей платежеспособности предприятия также во многом зависит от качества распределения прибыли, так как прибыль является основным источником погашения обязательств компании.

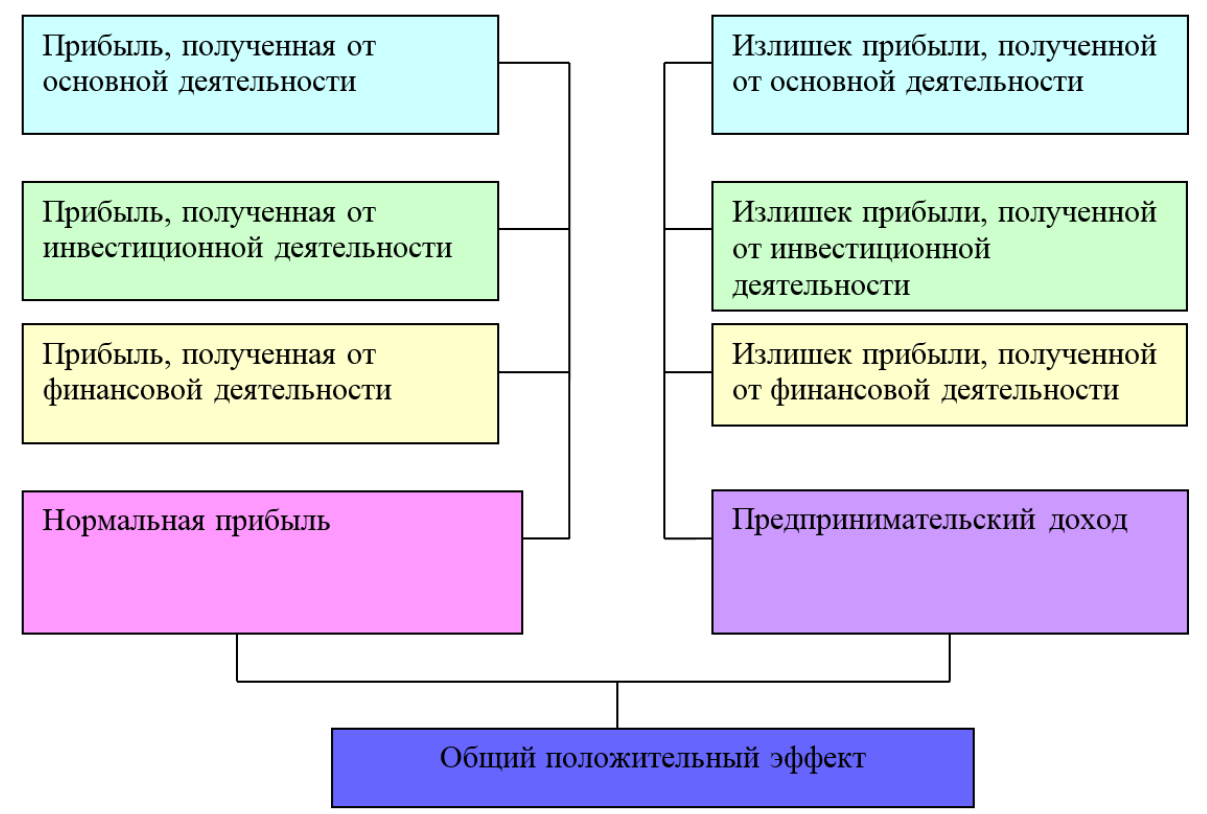

Рис. 23. Процесс формирования прибыли предпринимательских структур

При выполнении типового набора сервисных работ для предпринимательской структуры холдингового типа нефтегазовой отрасли, сервисная предпринимательская структура осуществляет свою деятельность на условиях повременной оплаты. 
Таким образом, внедрение инновационных решений управленческого и технологического характера, ускоряющих процесс реализации работ, в большинстве случаев ведет к сокращению нормальной прибыли, однако предпринимательский доход может компенсировать ее снижение при грамотном алгоритме внедрения и использования инноваций. Однако количество оказанных услуг за продолжительный период времени растет. Предпринимательский доход может иметь место, но при этом его масса так же ставится в зависимость от сроков использования инноваций для конкретных видов работ и конкретных объектов.

Холдинговая предпринимательская структура устанавливает внутренние лимиты оплаты сервисных работ, косвенным образом формирующие себестоимость основного продукта деятельности. Более того, своевременное выполнение сервисных работ обеспечивает бесперебойность технологического процесса, а ряд работ сервисного характера требуют полной остановки деятельности на отдельных участках работы предпринимательской структуры НГК.

Налицо асимметрия задач выполнения сервисных работ аффилированной предпринимательской структуры для холдинговой предпринимательской структуры: обе структуры заинтересованы в выполнении работ быстрее установленных нормативов, обе структуры заинтересованы в качественном выполнении работ, обе структуры готовы поддерживать внедрение и использование инноваций в процесс оказания сервисных услуг и выполнение сервисных работ, однако решаемые при этом задачи разнятся (рис. 24). При этом холдинговая предпринимательская структура заинтересована в получении дополнительного дохода от ускорения выполнения сервисных работ и перехода к основному циклу производства.

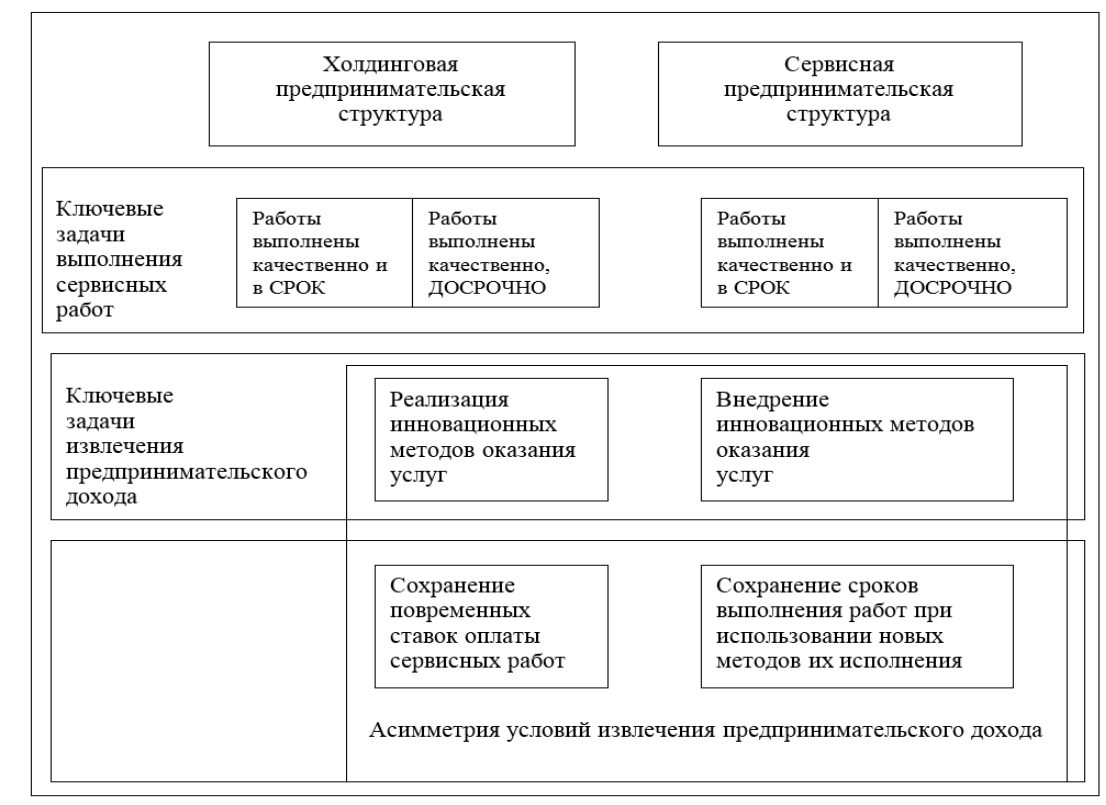

Рис. 24. Асимметрия условий и задач выполнения сервисных работ аффилированной предпринимательской структурой для холдинговой предпринимательской структуры 
Таким образом, во взаимоотношениях между холдинговой и сервисной предпринимательскими структурами формируются, с одной стороны, благоприятные условия для внедрения и использования инноваций, которые ускоряют процесс оказания сервисных услуг, с другой стороны, сам факт сокращения количества времени на выполнение работ снижает массу предпринимательского дохода, который можно извлечь по нормам и нормативам выполнения работ, определяемым холдинговой предпринимательской структурой.

Решение проблем, связанных с асимметрией условий и задач выполнения сервисных услуг, может быть реализовано через дополнительные соглашения между сервисными предпринимательскими структурами и предпринимательской структурой холдингового типа, определяющие премирование за применение инновационных решений, которые способствовали более качественному и быстрому выполнению работ. Таким образом, мы получим прямое финансирование инновационных идей, а предпринимательский доход получит четкое отображение в платежах.

Для определения суммы вознаграждения предпринимательские структуры должны придерживаться ряда принципов: 1) принцип измеримости результатов - в отношениях между сервисной и холдинговой предпринимательскими структурами должны иметь место конкретные, измеримые результаты работ; 2) принцип единых метрологических требований - необходимо обеспечить возможность измерения конкретных показателей работ (сроков, качества, трудозатрат); 3) принцип доступности информационных потоков - в отношениях взаимодействий должно быть обеспечено наличие источников информации о состоянии объективных показателей; 4) принцип сохранения партнерских отношений формирование предпринимательского дохода может происходить лишь в налаженных отношениях между холдинговой и сервисной предпринимательскими структурами, не может возникнуть с первого договора. 


\section{ГЛАВа 4. РАЗВИТИЕ ЛОГИСТИЧЕСКОЙ ПОДСИСТЕМЫ РЕГИОНАЛЬНОЙ ИНФРАСТРУКТУРЫ}

\section{1. Роль и место логистики в инфраструктуре нефтегазового комплекса}

Северные регионы, выбранные в качестве объекта исследования, заинтересованы в успешности крупных проектов, которые в них реализуются. Особенно актуальной представляется задача развития СМП, привлекательного для азиатских стран и России. Приарктические регионы сейчас испытывают дефицит рабочих мест, а бюджеты большинства из них являются дотационными. Развитие СМП и создание новых логистических цепочек и центров позволит этим регионам стать самодостаточными.

Любую экономику невозможно представить без одной из важнейших составляющих - логистики. В европейских странах и Америке в последние четыре десятилетия коммерческая логистика стала частью экономики многонациональных компаний. Логистическая цепь, или цепь поставок, представляет собой единую структуру, в которой работает огромное количество предприятий, объединяющих усилия со своими поставщиками, чтобы эффективно доставить товары, услуги и информацию от производителя до потребителей.

Логистика связывает в единый процесс такие разнообразные виды деятельности, как производство, информационный обмен, транспортировка, управление запасами, складское хозяйство, грузопереработка, упаковка и доставка. При этом наиболее яркая особенность современной логистики в том, что она обеспечивает комплексный результат на всей цепи за счет внутренней и внешней интеграции всех элементов транспортной инфраструктуры.

Менеджмент, занимающийся созданием и налаживанием таких систем управления потоками материальных ресурсов, которые служили бы опорой для деловой стратегии развития предприятия, должен обладать обширными знаниями о географическом расположении собственных поставщиков и всех покупателей. Общая задача логистики любой компании состоит в том, чтобы обеспечить намеченный уровень обслуживания потребителей товаров и услуг при минимальных общих издержках. В любой сделке покупатель хочет получить нужный товар высокого качества в требуемом количестве и в согласованных месте, времени и виде, что и является целевой функцией логистики. На любом предприятии логистика начинается с получения материалов или комплектующих от фирмыпоставщика и заканчивается, когда произведенный внутри фирмы продукт доставляется покупателю.

В логистике в расчет принимается управление материалами, полуфабрикатами и готовой продукцией на всем пути следования между поставщиками, производителями, оптовыми торговцами и покупателями товара фирмы. В этом смысле логистика есть стратегическое управление движением и хранением товаров, материалов и услуг во всей цепи поставок.

В процессе логистики реализуются ее основные функции: обслуживание покупателей, транспортировка товара, управление запасами 
и дистрибуция. Во многих фирмах она интегрирована с другими функциями, с деятельностью внешних поставщиков и покупателей товаров фирмы, но перечисленные виды деятельности составляют ядро любой логистической цепочки.

Главное в логистике - найти решение, которое позволит с минимальными совокупными затратами удовлетворить потребности клиентов фирмы, что возможно сделать, используя принцип компромисса, предполагающий, что воздействие на материальный поток приводит к уменьшению затрат по одним статьям и к увеличению по другим при продвижении товара. Логистика - это широко распространенная и повсеместно признанная функция бизнеса, охватывающая проблемы физического перемещения товаров в пространстве и движение во времени на всех стадиях деятельности предприятия, а также комплексная функция управления производством и сбытом продукции.

Логистика при такой постановке проблемы объединяет маркетинг, производство, инновации, а также хозяйственную деятельность предприятия, осуществляя различные функции по договорам с другими предприятиями. Она направлена на реализацию единого процесса по физическому перемещению во времени и пространстве имеющихся в распоряжении этого предприятия материалов, обеспечивающих собственное производство от поставок исходного сырья и материалов до доставки произведенного им товарного продукта конечному потребителю, т. е. через все стадии производственного цикла. Ролевой статус логистики как комплексной управленческой функции предприятия должен определяться эффективностью единого процесса ее осуществления, критерием которой является минимум совокупных издержек на осуществление всего комплекса операций сферы хозяйственной деятельности, если такой минимум не обеспечивается, то соответствующую деятельность или управление этой деятельностью нельзя признать логистическими.

Предприятие за определенный период времени формирует множество конкретных логистических цепей по продвижению всего ассортимента товара. При этом каждая конкретная логистическая цепь может отличаться от других индивидуальными особенностями, количественными и качественными значениями однотипных для всех цепей или систем параметров. Это вызвано тем, что у предприятия редко может быть такая ситуация, когда оно имеет одного конечного потребителя в одной и той же географической точке, работает с одним и тем же поставщиком либо постоянно производит товар с одними и теми же свойствами. Логистика осуществляется только в отношении материального потока, т. е. объектом логистической деятельности является исключительно материалы или товары.

Источником финансирования логистической деятельности, организатором движения собственных материальных ресурсов в своих интересах и своими силами совместно с другими компаниями может являться только предприятие, действующее как самостоятельный экономический субъект.

Россия обладает уникальными транспортно-логистическими возможностями, которые превращают еe на рынке международных транспортных перевозок в исключительно конкурентного участника 
с развитой сферой сервисных услуг. Одним из перспективных направлений может стать реализация ее транспортного потенциала и транспортной инфраструктуры, связывающей труднодоступные населенные пункты [5].

В настоящее время сухопутная российская транспортная система связывает между собой страны Европы, Азии, Ближнего Востока через осуществление перевозок по международным транспортным коридорам с привлечением на российские железные дороги транзитного грузопотока. По мнению экспертов, российские железные дороги обладают высокой конкурентоспособностью по сравнению с морскими маршрутами. Например, суда-контейнеровозы вместимостью до 12 тыс. контейнеров и более позволяют обеспечивать высокий уровень фрахтовых ставок, который поддерживает достаточную конкурентоспособность морских перевозок на основных трассах торговли Европа - Азия [36].

Особую актуальность приобретает проблема транспортного обеспечения северных регионов России, в связи с чем возрастает роль и значение СМП - самого короткого и дешевого пути между Тихоокеанским и Атлантическим регионами, имеющего большие возможности коммерческой реализации, в которой заинтересована Россия для укрепления своей национальной и экономической безопасности.

Однако превращение СМП в круглогодично действующую морскую магистраль на современном этапе маловероятно из-за отсутствия мощных современных ледоколов, способных выполнять проводку судов усиленного ледового класса высокоширотными маршрутами. СМП остается резервом международной транспортной системы, которая проходит через Суэцкий канал. Хотя Россия приступила к практическому освоению арктических территорий, широкомасштабные проекты ждут своего часа.

Россия в Арктике сегодня заявляет о своих правах на территории, являющиеся спорными, на них также имеют претензии другие арктические государства. При этом у России есть технологические преимущества: мы единственная страна, владеющая действующим ледокольным флотом, который сейчас представлен группой одно- и двухреакторных судов [19].

Одна из важнейших задач России в настоящее время состоит в освоении в Северном Ледовитом океане больших запасов углеводородов. Современная конъюнктура не позволяет успешно развивать эти проекты, так как главными являются стоимость барреля нефти и себестоимость ее добычи. Для этого требуются серьезные финансовые вложения, которые помогут сформировать новый образ жизни в северных регионах, качественную транспортную и информационную инфраструктуру для комфортного проживания населения. Реализация арктических проектов на новых территориях идет успешно в Ямало-Ненецком и ХантыМансийском автономных округах, где имеются условия для проживания населения, участвующего в освоении природных ресурсов. На других северных территориях и Дальнем Востоке идет постоянный отток трудоспособных молодых специалистов, не имеющих возможности реализовать свой профессиональный потенциал [15].

Китай предложил в 2013 г. концепцию Морского шёлкового пути для связи китайских портов с портами Сингапура, Малайзии, Индонезии, Австралии через Россию и Казахстан с использованием СМП. К сожалению, 
Россия оказалась ненадежным партнером в этом проекте, так как не выполняет свои обязательства. Так, например, в Еврейской автономной области проект моста через Амур согласовывали более десяти лет. В Китае такое же решение было оперативно принято, и свою часть моста они уже построили, в то время как наши компании еще не приступили к строительству.

Однако российско-китайское сотрудничество в области модернизации портового хозяйства на Дальнем Востоке имеет и позитивный пример - порт Зарубино в Приморском крае. Китай уже вложил в его развитие 3 млрд долл. США и приступил к работе. В 2014 г. принято решение о постройке совместными усилиями российской и китайской компаний контейнерного терминала в порту Славянка на юге Приморского края мощностью 10 млн т грузов в год.

Россия рассчитывает на перевозку грузов не только Китая, но и всех стран АТР, что может составлять не менее 40 млн контейнеров в год. По мнению специалистов, Россия может также зарабатывать на сдаче в аренду ледоколов. Китай располагает двумя ледоколами, но они используются для организации научных арктических экспедиций. Благодаря использованию и продаже ледоколов Китаю и другим странам, Россия получит возможность заработать не за счёт ресурсов, а за счёт уникальных технологий, что будет способствовать модернизации ее экономики.

Цели России и Китая - создать экономический блок, который обеспечил бы получение прибыли от эффективной совместной деятельности, а также занять нишу в перевозках и зарабатывать на них, потеснив американцев, за что идет борьба на рынках морских перевозок.

Предпринимаемые Правительством Российской Федерации меры по освоению Арктики сегодня явно недостаточны для того, чтобы СМП и арктические регионы стали эффективными. Нужны вложения в инфраструктуру и логистику, которые Россия самостоятельно выделить не в состоянии. Бизнес собственные длинные деньги вкладывать не заинтересован: он придет, когда будут все предпосылки для получения прибыли. Сегодня реальность такова, что в ближайшее время работы по СМП и Великому шелковому пути не начнутся, так как у России нет на это финансов, а приглашать партнеров правительство не решится, чтобы не потерять суверенитет над собственной территорией [16].

\section{2. Формирование и развитие логистической инфраструктуры в регионах}

Создание эффективной региональной логистической системы представляется особенно важной задачей с точки зрения развития экономики регионов и создания крупных инфраструктурных проектов. Особый интерес представляют в этой связи северные регионы страны, которые являются сугубо дотационными и требуют серьезных инвестиций.

В последние четыре десятилетия логистика стала частью экономики современных компаний, кооперирующих при производстве высокотехнологичных продуктов. Логистические цепи поставок - это единая структура, в которой работает огромное количество предприятий: фирма «Тойота» при производстве одного автомобиля объединяет 
293 поставщика для того, чтобы эффективно производить 43 типа автомобилей на всех континентах в количестве более 11 млн штук и доводить информацию и рекламу от производителя до потребителей.

Логистику с теоретической точки зрения можно представить как элемент системы управления производством, в функции которого входит интегрировать в единый комплекс такие операции технологического процесса, как складирование продукции, еe транспортировка, информационное сопровождение и доставка до потребителя в сроки, объеме, качестве и номенклатуре, которые определены договором и соглашениями. По сути, это инструмент, позволяющий использовать современные методы управления сложными процессами, связанными с маркетингом рынка, обеспечением руководства своевременной и достоверной информацией; транспортировкой и обеспечением безопасности при сопровождении грузов; организацией, если нужно, таможенного сопровождения; правового обеспечения; рационального использования финансовых, материальных и человеческих ресурсов.

В качестве основных видов логистики выделяются: производственная, завершающая процесс производства, хранения и подготовки продукции к транспортировке; закупочная, связанная с заключением договоров на поставку продукции; распределительная - организация взаимодействия всех участников процесса логистики; сбытовая - собственно, сама доставка продукции до потребителя; транспортная - выбор вида транспорта, водителей и определение маршрута движения продукта до потребителя; таможенная - в случае поставки продукции за рубеж; информационная - сбор, анализ и обработка информации, необходимой для эффективной работы логистического комплекса.

Речь идет о создании и функционировании инфраструктуры логистической подсистемы в общей системе управления, реализующей специфические задачи менеджмента компании, которые должны вписываться в общую цель менеджмента, состоящую в обеспечении высокого уровня и качества выполненных работ при минимальных издержках с учетом, что потребитель ожидает получить нужный товар высокого качества в требуемом количестве и в согласованных месте, времени и виде. Это, в свою очередь, значительно повышает требования к менеджменту компании, который должен провести качественный маркетинг рынка товаров и услуг и быть в состоянии четко определить стратегию, географию и маршруты всех звеньев логистической цепи доставки продукции.

Определенный принятый стратегией статус логистики как комплексной управленческой функции предприятия обусловлен современной концепцией конкурентной политики компании, он должен определяться эффективностью единого процесса управления на рынке.

При такой постановке проблемы логистика объединяет маркетинг, производство, хранение и сбыт продукции, инновационную, а также хозяйственную деятельность предприятия, осуществляя различные функции управления, закрепленные за нею в соответствии с принятой стратегией компании [5].

Если же говорить об оперативной составляющей логистики, то ее функции сводятся к организации правильного хранения продукции; 
определению субъектов сбыта; организации упаковки и транспортировки грузов; обеспечению транспортом и водителями; четкому соблюдению сроков и маршрутов поставки.

Предприятие формирует множество конкретных логистических цепей по продвижению ассортимента товара на рынке. Логистическая цепь имеет свои индивидуальные особенности, количественные и качественные значения. Упомянутая выше фирма «Тойота» для своих цепей привлекает на производство одного автомобиля к 293 поставщикам еще 3017 поставщиков для производства комплектующих, так как у предприятия высокая степень кооперации при производстве высокотехнологичного продукта, когда имеется много потребителей в разных географических точках или когда оно работает с разными поставщиками на разных континентах, постоянно производящими товар с одними и теми же свойствами.

Великая северная мечта. Идея создать в русском Заполярье железнодорожную магистраль, которая позволила бы объединить порты и населенные пункты на гигантской территории от Баренцева до Карского морей (а в идеале - соединить месторождения, расположенные на Оби, с портом Мурманска), вынашивалась с начала XX в.

Ни один из предложенных проектов до революции так и не был принят, однако сама концепция успела получить название Великого Северного железнодорожного пути. Самый амбициозный из вариантов предполагал маршрут от Мурманска до Татарского пролива, т. е. практически до Владивостока.

Интерес к идее железнодорожного пути от Мурманска до Дальнего Востока вновь возник в конце 1920-х гг., причем было очевидно, что со временем промышленное значение северных районов будет лишь расти. Однако тогда строительство не состоялось: имевшиеся ресурсы предпочли бросить на развитие СМП.

К строительству железной дороги в Заполярье все-таки вернулись, правда, речь шла о значительно более ограниченном участке - от Чума (города на Оби, недалеко от Салехарда) через Надым и Новый Уренгой до расположенного на Енисее города Игарки. Тем не менее общая протяженность магистрали должна была составить больше 700 км (столько же составляет и протяженность Северного широтного хода, который фактически повторит ее маршрут) в условиях тундры и вечной мерзлоты. Не хватало ни специалистов (их в конце концов начали набирать из числа заключенных), ни техники - вместо тракторов строителям приходилось использовать старые танки БТ, с которых снимали башни, а в роли мотодрезин выступали поставленные на рельсы, полученные по ленд-линзу студебеккеры. Несмотря на то что замысел, а главное, заявленные сроки с самого начала казались нереальными, к весне 1953 г. строителям оставалось проложить лишь несколько десятков километров дороги под Новым Уренгоем. Еще почти 700 км рельсов уже были проложены, правда, качество полотна оставляло желать лучшего. Скорость движения составов на некоторых участках не превышала 10 км/ч. Весной 1953 г. работы было решено законсервировать. Большинство специалистов вместе с техникой перебросили на другие северные стройки.

Часть путей продолжили использовать, однако большинство объектов приходило в запустение. Колеи поросли деревьями, насыпи проседали, рельсы 
покосились, а в некоторых местах не сохранились вовсе. Тем не менее, десятилетиями сохраняясь в условиях такой естественной консервации, «мертвая дорога» оставалась молчаливым «живым» памятником труду ее строителей и фактически стихийным «музеем» под открытым небом.

Российские железные дороги имеют высокую конкурентоспособность (табл. 10). Актуальность приобретает проблема транспортного обеспечения северных регионов России, возрастает роль и значение СМП, имеющего большое значение для коммерческой деятельности, что позволит укрепить национальную и экономическую безопасность страны [13]. Однако СМП не стал действующей международной транзитной магистралью, несмотря на все решения правительства, из-за отсутствия мощных ледоколов, выполняющих проводку судов арктическими маршрутами.

Таблииа 10

Перевезенные грузы за январь - сентябрь 2017 и 2018 гг., млн т

\begin{tabular}{|c|c|c|c|}
\hline & \multicolumn{2}{|c|}{ Январь - сентябрь } & \multirow{2}{*}{ Темп прироста, \% } \\
\hline & 2018 г. & 2017 г. & \\
\hline Погрузка, млн т & 962,26 & 937,31 & $+2,7$ \\
\hline каменный уголь & 276,33 & 262,96 & $+5,1$ \\
\hline нефть и нефтепродукты & 175,9 & 175,2 & $+0,4$ \\
\hline руда железная марганцевая & 86,5 & 82,4 & $+5,0$ \\
\hline черные металлы & 58,8 & 53,5 & $+9,9$ \\
\hline удобрения & 44,2 & 42,5 & $+4,0$ \\
\hline цемент & 19,7 & 21,22 & $-7,2$ \\
\hline лесные грузы & 34,74 & 33,4 & $+4,0$ \\
\hline зерно & 20 & 14,61 & $+36,9$ \\
\hline строительные грузы & 96,67 & 101,897 & $-6,1$ \\
\hline руда цветная и серное сырье & 15,211 & 15,295 & $-0,5$ \\
\hline химикаты и сода & 19,78 & 19,336 & $+2,3$ \\
\hline промсырье & 26,53 & 27,41 & $-3,2$ \\
\hline $\begin{array}{l}\text { Тарифный грузооборот, млрд } \\
\text { тарифных тонно-км }\end{array}$ & 1928,4 & 1846,3 & $+4,4$ \\
\hline $\begin{array}{l}\text { Общий грузооборот, млрд } \\
\text { тарифных тонно-км }\end{array}$ & 2453,6 & 2354 & $+4,2$ \\
\hline
\end{tabular}

Россия осваивает в Арктике территории, которые будут востребованными из-за уникальных природных ресурсов [7]. Развитие глобальных транспортных путей всегда тесно связано с геополитикой и политикой государства по обеспечению проживающего в Арктике населения всем необходимым, т. е. с северным завозом. Экономическое могущество страны напрямую зависит от возможности вывоза продукции из порта Сабетта с доставкой в Европу и страны АТР (рис. 25). Сегодня из восемнадцати газовозов ледокольного класса работают пять, остальные в процессе строительства, что не позволяет осуществлять вывоз сжиженного газа круглогодично. Необходимо организовать в районе Мурманска перегруз газа с газовозов ледокольного класса на простые газовозы, чтобы увеличить сроки вывоза СПГ. 


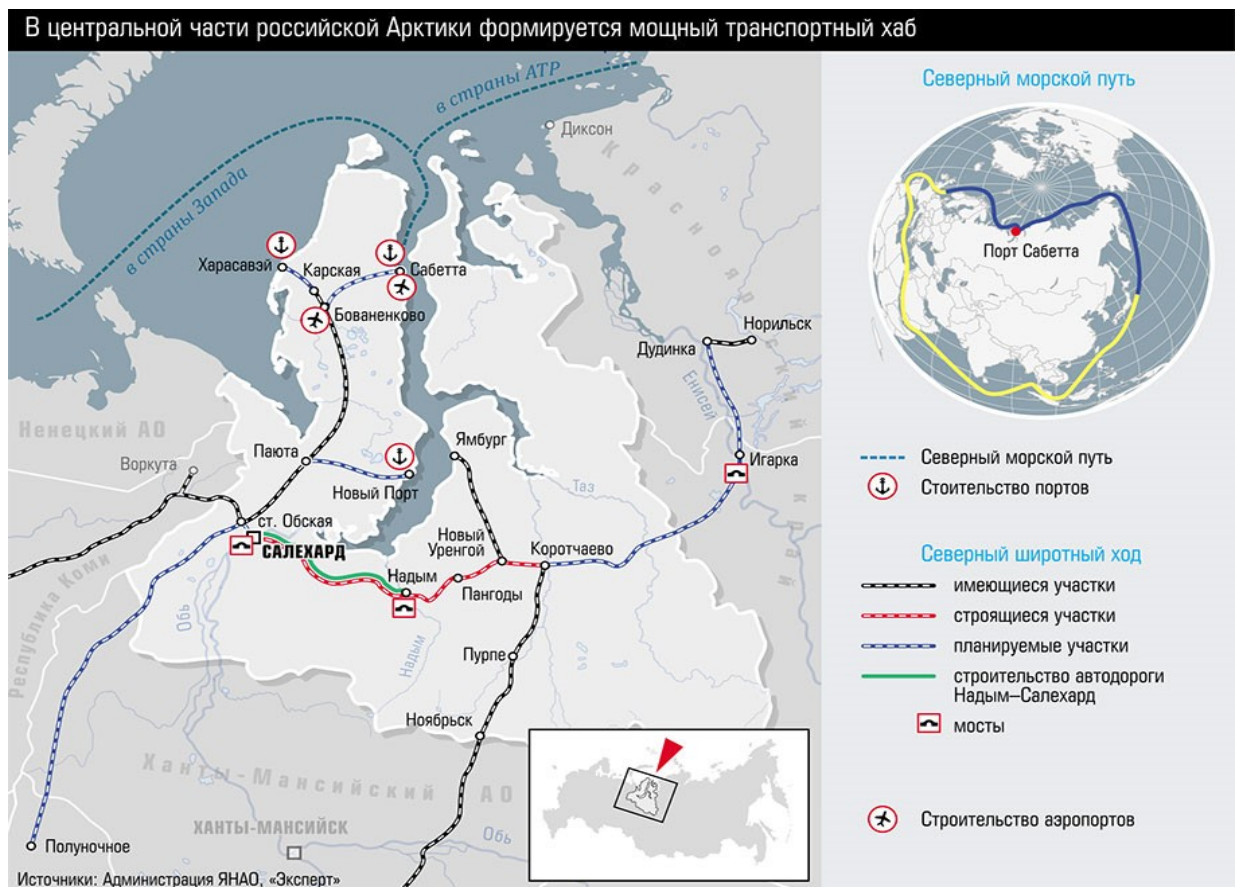

Рис. 25. Сабетта и СМП

Проекты создания транспортных коридоров для международных перевозок рождаются на фоне перемен в расстановке сил на мировой арене. Российские арктические регионы имеют разные экономические возможности, Ханты-Мансийский и Ямало-Ненецкий автономные округа обладают большими запасами нефти и газа. Из Ханты-Мансийского автономного округа доставка нефти идет по нефтепроводам, других путей доставки нет.

В Якутии, Магаданской области и Чукотском автономном округе добывается около $30 \%$ золота России, а в Архангельской и Мурманской областях - более 20 \% рыбы. На севере Красноярского края существует знаменитый Норильский ГОК.

На современном этапе главным для активного развития экономики в части территории является СМП, так как не существует других возможностей вывоза продукции. Морской транспорт на Севере обеспечивает доставку грузов для населения регионов и группировки войск в Арктике [12].

Одной из самых больших проблем, которые стоят перед нашей страной, является уточнение исходных линий территориальных вод России в Арктике, так как идет много споров, как их правильно определять и законодательно закрепить, отстоять и защитить в международных организациях. Кроме того, необходимы законодательные акты использования северных территорий и шельфа, которые должны принять региональные власти, чтобы определить правила для работы на их территориях. Утвержденная президентом программа развития Арктики должна защищать национальные интересы Российской Федерации в связи с интересом к богатствам данного региона многих стран мира и спорами вокруг добычи 
углеводородного сырья в данном районе Северного Ледовитого океана, который является стратегической ресурсной базой будущего развития Российской Федерации на длительную перспективу. В последнее время в мире все острее встает проблема скорого истощения запасов углеводородов. В России 80 \% разведанных запасов углеводородного сырья находится на шельфе, и тенденции таковы, что добыча с континента все больше перемещается в море. Наша страна, безусловно, не является лидером в этой отрасли: с шельфа добывается всего около $3 \%$ российской нефти, а в мире - $40 \%$. В настоящее время добыча углеводородного сырья на суше падает на 2-6 \% в год, истощаются существующие места добычи, при этом спрос вырос на $2 \%$.

Воссоздание постоянно действующих дрейфующих полярных станций, полярной авиации для их обслуживания, восстановление гражданской авиации в северных регионах, создание необходимого класса самолетов для работы в северных широтах, которые практически не производятся, позволит вернуть население в Заполярье. Восстановление в полном объеме системы защиты и охраны государственной границы России современными средствами и дальнейшее развитие навигационногидрографического обеспечения мореплавания в северных морях - все это будет способствовать ускоренному развитию инфраструктуры региона. В России в настоящее время осталось 159 аэропортов, и их количество постоянно сокращается, хотя в 1990 г. их было 1302 (рис. 26). В США их 3363, а на Аляске - 142. Как жить на северных территориях, где в субъектах Федерации сократилось количество портов в полтора раза? Государство принимает решения о субсидировании авиационных перевозок с Дальнего Востока и северных территорий Сибири, но этого явно недостаточно.

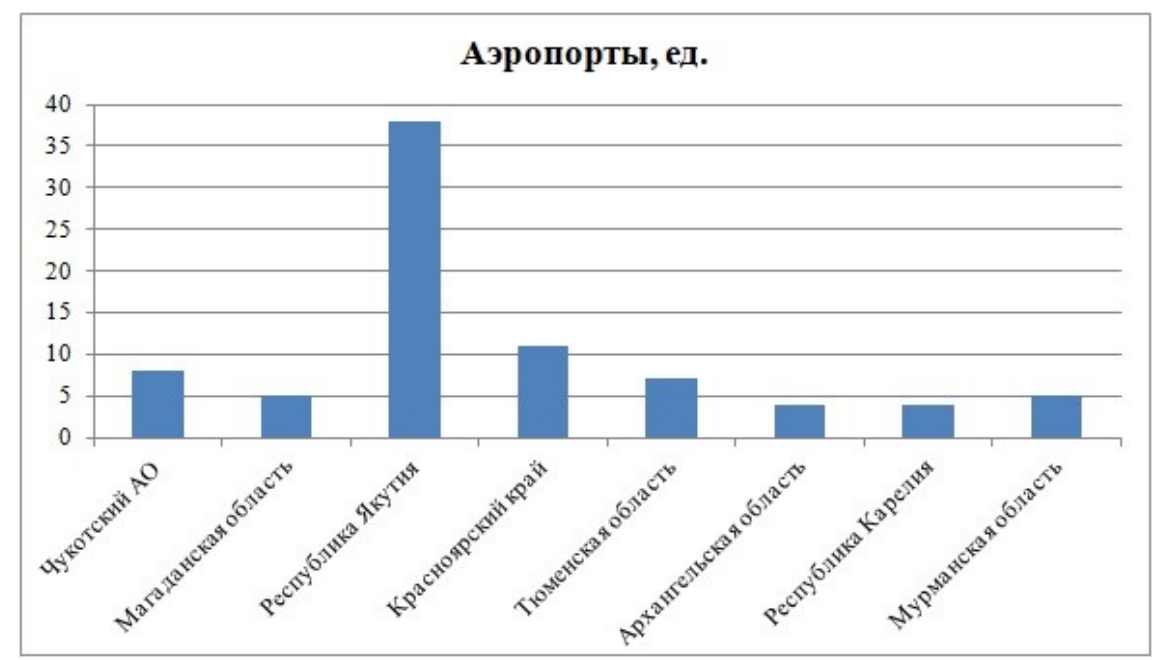

Рис. 26. Аэропорты регионов Арктики

Регионы заинтересованы в транспортной инфраструктуре, так как для части северных территорий главным транспортным средством сегодня является авиация. Более того, в северных городах необходимо создать 
комфортную среду для проживания, т. е. современное городское хозяйство. Современные технологии позволяют выращивать продукты питания там, где раньше это считалось нерентабельным, некоторые регионы являются лидерами по развитию сельского хозяйства, особенно там, где достаточно энергии или газа.

Развитие транспортных коммуникаций обусловлено геополитикой. Из-за введения санкций против России существует проблема доставки углеводородного сырья в страны Европы через Украину. Для выполнения контрактов и удержания рынков возникла необходимость строительства новых газопроводов в обход Украины и Польши, активно поддерживающих санкции. Газопроводы «Северный поток - 2» и «Турецкий поток», которые были запущены в декабре 2019 г., позволяют пропустить основной объем газа потребителям в Европе, но в связи с ростом потребления покрыть весь объем не удается. Объем «Северного потока - 1 и 2»- до 110 млрд м м $^{3}$, «Турецкого потока» - до 30 млрд ${ }^{3}$, через Белоруссию и Польшу - около 40 млрд м $^{3}$. Есть два варианта решения проблемы: 1) поставки сжиженного газа компанией «НОВОТЭК» из порта Сабетта; 2) продолжать доставку через Украину, несмотря на кризис в отношениях с ней, для покрытия недостающих мощностей. Евросоюз заинтересован в прокачке части газа именно через Украину, чтобы снизить риски ухудшения отношений с Россией.

Экономическое могущество государства зависит от господства над мировыми торговыми путями и доступа к освоению новых территорий. Создание транспортных коридоров для международных перевозок происходит на фоне экономических перемен, при расстановке сил на глобальных рынках мира. В первую очередь, речь идет о росте экономики Китая, превращении его в лидера мирового производства товаров народного потребления и усилении международной торговли [11].

Обсуждаемые проблемы по разработке концепции Морского шёлкового пути для связи Европы и АТР с пропуском судов по СМП и железнодорожным транспортом из Китая в Европу через Казахстан, как было сказано ранее, длительное время не решены, так как Россия оказалась ненадежным партнером и не выполняет свои обязательства в проекте строительства моста через Амур в Еврейской автономной области. На Восточном экономическом форуме 2018 г. в очередной раз обсуждали сроки сдачи этого моста. Выяснилось, что таможенной инфраструктурой никто не занимается [35].

Россия заинтересована в перевозке грузов стран АТР, что позволит загрузить Транссиб, а «РЖД» принесет прибыль транзит. Специалисты считают, что Россия может зарабатывать на сдаче в аренду ледоколов для навигации по СМП и в дальневосточных морях, а также на уникальных технологиях при строительстве и продаже ледоколов в Китай и другие страны, развивая собственную экономику [34].

Правительство Российской Федерации принимает меры для того, чтобы СМП и развитие арктических регионов стали эффективными, приносили прибыль компаниям и деньги в бюджет, но Россия не в состоянии самостоятельно инвестировать в транспортную инфраструктуру СМП, а искать партнеров еще не готова. Крупные компании не заинтересованы 
вкладывать деньги без гарантий правительства, а малый и средний бизнес придет, когда появятся предпосылки для получения прибыли.

\section{3. Организация управления транспортно-логистической системой}

Транспортно-логистическая система в Арктике является главным связующим звеном между развивающейся экономикой и населением, проживающим на северных территориях. Транспортные коммуникации основа пространственной организации экономической деятельности российских компаний на Севере [16]. Морской транспорт обеспечивает доставку грузов для населения регионов и группировки войск в Арктике [36].

Большие запасы нефти и газа, которые поделены между основными нефтяными компаниями, являются лишь одной из составляющих экономики арктических регионов. На рис. 27 представлены данные о распределении углеводородных запасов в Арктике.

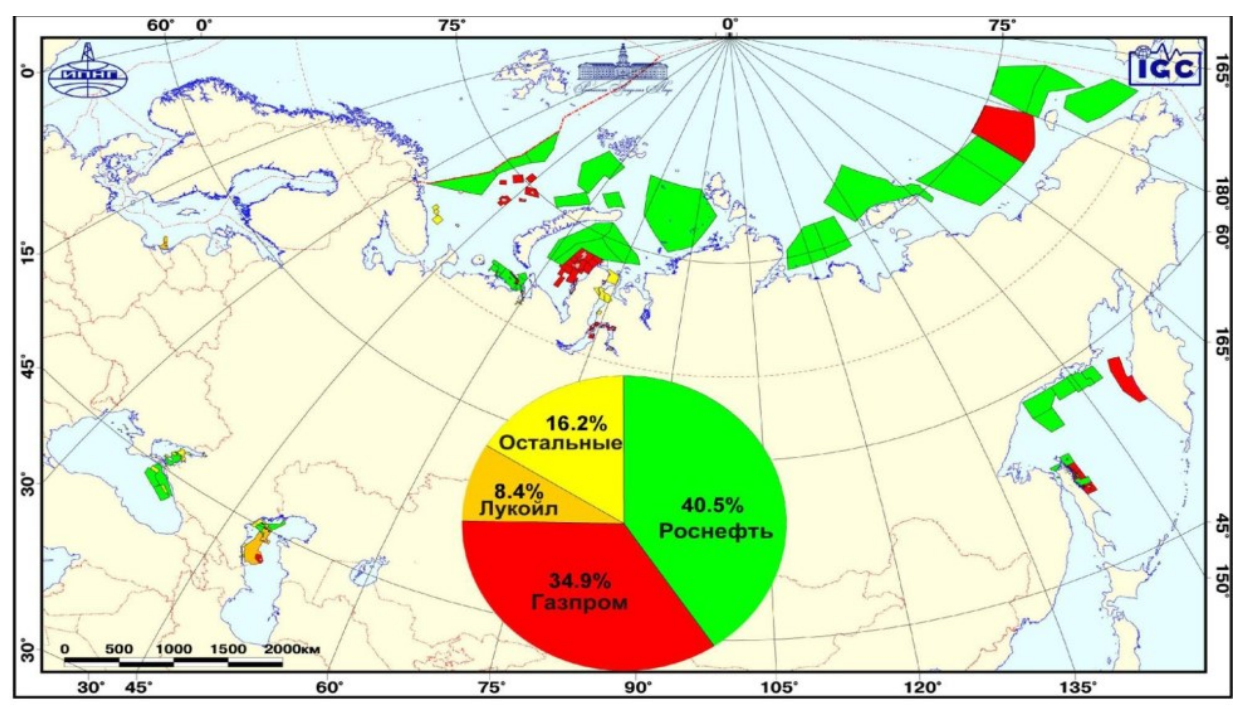

Рис. 27. Карта распределения углеводородных запасов в Арктике

В Мурманской области развиты горнодобывающая промышленность и цветная металлургия. Крупнейшие предприятия: «Апатит» - производство апатитового концентрата; «Кандалакшский алюминиевый завод» производство первичного алюминия; «Кольская горно-металлургическая компания» - производство никеля, рафинированной меди, серной кислоты; «Оленегорский ГОК» - производство железорудного сырья; Ковдорский горно-обогатительный комбинат - производство апатитового и железорудного концентратов.

Рыбная индустрия - Мурманский траловый флот (г. Мурманск) и десятки частных предприятий по добыче и переработке рыбы. В советское время существовало объединение «Севрыба», которое работало на территории Мурманской и Архангельской областей. 
Архангельская область - это предприятия лесной, деревообрабатывающей (главными из них являются АО «Архангельский целлюлозно-бумажный комбинат», Группа компаний «УЛК», «Лесозавод $25 »)$ и целлюлозно-бумажной (Котласский целлюлозно-бумажный комбинат, Котласский химический завод, Архангельский ЦБК) промышленности, компании, занимающиеся разведкой, добычей и переработкой нефти (ООО «Башнефть-Полюс», АО «Архангельскгеологодобыча» и АО «ННКПечоранефть»).

На территории области, в городе Северодвинске, находится Центр атомного судостроения России, где производят атомные подводные лодки. Атомоходы - подводные лодки проекта 945 «Барракуда» с прочным корпусом из титановых сплавов, атомный подводный ракетоносец «Акула».

Около города Мирного находится космодром Плесецк, имеется машиностроение (ПО «Севмаш», ЦС «Звёздочка», Котласский электромеханический завод, Соломбальский машиностроительный завод), выполняющие оборонный заказ, а также обслуживающие рыбную и деревообрабатывающую промышленность. Область располагает значительными неосвоенными запасами природных ресурсов: лес, нефть, газ, бокситы, титановые, медно-никелевые и свинцово-марганцевые руды, золото, базальт.

В Архангельской области открыта единственная в Европе алмазоносная провинция, где сосредоточено $20 \%$ российских запасов алмазов. Идёт их промышленное освоение. Разведаны и эксплуатируются месторождения нефти и газа в Большеземельской тундре, в том числе знаменитое Варандейское.

Архангельская область имеет доступ к морю и обладает развитой рыбной промышленностью (Архангельский траловый флот).

В Ямало-Ненецком автономном округе производится более 2 трлн руб. валового национального продукта. Здесь идет добыча нефти и газа. Основным добытчиком газа является ОАО «Газпром», на долю которого приходится примерно $90 \%$ всей его добычи в округе. Добычу нефти и газового конденсата ведут более тридцати предприятий. Основными нефтедобывающими предприятиями в округе являются дочерние компании OAO «Газпром нефть», ОАО «Газпромнефть-Ноябрьскнефтегаз» и «Новатэк».

18 января 2016 г. в компании «Новатэк» заявили, что проект СПГ в пункте Сабетта профинансирован на 15 млрд долл. США. Подрядчиком по строительству производственных объектов является Yamgaz SNC совместное предприятие фирм Technip и JGC Corporation. Основным подрядчиком по строительству скважин является компания ЗАО «Инвестгеосервис». Договор подряда предусматривает строительство более ста скважин под ключ. На 2013-2021 гг. на месторождении работают три уникальные буровые установки «Арктика» грузоподъёмностью 400 т, разработанные АО «Инвестгеосервис» совместно с «Уралмаш» специально для реализации проекта по строительству скважин на Южно-Тамбейском месторождении. 11 октября 2010 г. распоряжением Правительства Российской Федерации № 1713-р был принят комплексный план по развитию производства СПГ на полуострове Ямал, по которому строительство завода 
по производству СПГ должно было начаться в 2012 г. и закончиться в 2018 г. Кроме того, предполагалось освобождение природного газа, предназначенного для сжижения, от налога на добычу полезных ископаемых до достижения накопленного объема добычи в размере 250 млрд м $^{3}$ при условии, что срок разработки запасов участка недр не превысит двенадцати лет с даты начала производства СПГ.

В 2013 г. компания «Новатэк» сообщила, что совет директоров ОАО «Ямал СПГ» принял окончательное инвестиционное решение (ОИР) по проекту, реализация которого предполагает строительство завода по производству СПГ, создание транспортной инфраструктуры, включающей морской порт и аэропорт в районе поселка Сабетта. Доставка газа в страны Азиатско-Тихоокеанского региона предусматривается в периоды отсутствия навигации по СМП. На момент начала освоения инвестиций в рамках проекта были проведены основные тендеры и заключены ключевые контракты. Также были размещены заказы на оборудование длительного срока изготовления (криогенные теплообменники, газовые турбины, компрессоры линий по сжижению), пробурены первые восемь эксплуатационных скважин. Была подготовлена площадка для строительства завода, начато сооружение свайного основания для резервуаров СПГ, начато строительство морского порта и аэропорта, законтрактовано более 70 \% планируемых к производству объемов СПГ.

9 ноября 2017 г. был произведен первый объем СПГ. Этот технический объем не был отправлен покупателям, а был использован для технологических целей.

К моменту запуска первой линии для обеспечения её электроэнергией на обслуживающей проект электростанции были введены в строй четыре из восьми планируемых газотурбинных блока SGT-800 мощностью 47 MBT каждый производства Siemens.

29 ноября 2017 г. ОАО «Ямал СПГ» получило государственное разрешение на ввод в эксплуатацию основных технологических объектов первой очереди завода СПГ.

5 декабря 2017 г. началось производство СПГ на первой производственной линии мощностью 5,5 млн т СПГ в год. Первая партия СПГ была закуплена трейдером группы «Новатэк» - Novatek Gas \& Power - для компании Petronas и направлена в Великобританию. Она была перевезена газовозом «Кристоф де Маржери» «Совкомфлота».

Предполагаются спотовая и контрактная формы реализации. По состоянию на конец 2017 г. законтрактовано порядка 96 \% производства. Акционеры проекта - Total и CNPC - будут закупать газ на долгосрочной основе у «Ямал СПГ».

Контракты на продажу СПГ имеют привязку к определенным портам или регионам. Примерно 86 \% продукции будет отправляться в АзиатскоТихоокеанский регион [32].

4 июля 2013 г. стало известно, что конкурс на производство шестнадцати СПГ-танкеров ледового класса для обслуживания проекта «Ямал СПГ», в котором участвовало семь ведущих верфей мира, выиграла южно-корейская Daewoo Shipbuilding \& Marine Engineering. 
С этой компанией было подписано соглашение о резервировании слотов, включающее в себя опционы на строительство, спуск на воду, оборудование, оснащение и поставку судов класса Yamalmax, а также устанавливающее предварительную стоимость судов, график их производства и поставки. Соглашение предусматривало передачу права на финансирование и покупку танкеров третьей стороне - компаниямперевозчикам, выбранным «Ямал СПГ». Плата за резервирование судостроительных мощностей составила 5,6 млрд долл. США.

В августе 2015 г., в связи с тем что у «Совкомфлота» возникли трудности с финансированием, дочерняя компания «Ямал СПГ» - Yamal Trade Singapore - переуступила права на пять из шести СПГ-танкеров, ранее предназначенных для «Совкомфлота», греческой судоходной компании Dynagas. Сумма сделки составила 1,5 млрд долл. США. Одновременно были подписаны долгосрочные договоры фрахтования этих танкеров.

Первое судно серии - газовоз «Кристоф де Маржери» - построено в марте 2017 г. и передано компании «Совкомфлот». К январю 2018 г. флот, допущенный к работе с «Ямал СПГ», пополнился еще тремя судами: «Борис Вилкицкий», «Федор Литке» (оба принадлежат греческой Dynagas) и «Эдуард Толль» (принадлежит канадской Теekay).

В 2017 г. в Ямало-ненецком автономном округе было добыто 431945 млн м ${ }^{3}$ природного газа, 65761 тыс. т нефти, 8824 тыс. т газового конденсата. Это $11,1 \%$ от всей добытой в стране нефти.

В 2017 г. более 23 \% работающих имели заработную плату свыше 100 тыс. руб. в месяц. По этому показателю Ямало-Ненецкий автономный округ занимает первое место в рейтинге среди регионов страны.

В округе существует развитое рыболовство, которое ведется малыми артелями, основной вылов приходится на сиговых рыб (муксун, нельму) севера Красноярского края. Объём вылова в 2016 г. составил 6500 т.

В Норильском регионе сосредоточены: более $95 \%$ российских запасов никеля и платиноидов, более 29 \% золота, значительные запасы кобальта, нефелиновых руд, магнезитов, исландского шпата, тонких кварцевых песков, тугоплавких глин, графита, 63 вида промышленных металлов и других полезных ископаемых, крупнейшие российские запасы угля. Масштабная угледобыча ведется в Канско-Ачинском бассейне и Тунгусском каменноугольном бассейне. Нефтегазовые месторождения Юрубченского блока, крупное Ванкорское нефтегазовое месторождение разведаны

и наращивают добычу. В крае открыто 25 месторождений нефти и газа, которые будут задействованы по проекту «Сила Сибири» для транзита в Китай и другие страны АТР.

Всего в Красноярском крае обнаружено более десяти тысяч месторождений и рудопроявлений различных полезных ископаемых. Благодаря значительным запасам металлических руд, наличию энергетических ресурсов и доставшейся с советского времени тяжёлой индустрии, край является абсолютным лидером среди регионов страны по выработке промышленного продукта на одного жителя: на регион приходится 3,2 \% всего объёма промышленной продукции, произведенной на территории России [2]. 
Большие энергетические ресурсы позволили создать крупный металлургический комплекс на юге края: Красноярская ГЭС - Красноярский алюминиевый завод - Ачинский глинозёмный комбинат - Красноярский металлургический завод (КрАМЗ). Предприятия Красноярского края производят около $27 \%$ российского первичного алюминия. Норильский никель производит более 70 \% российской меди, 80 \% никеля, 75 \% кобальта, более $90 \%$ металлов платиновой группы.

Экономику севера Красноярского края составляют крупные металлургические предприятия: «Норильский комбинат» (медь, никель, МПГ), проектируемые и строящиеся предприятия в Норильском районе, Енисейский ферросплавный завод. На рис. 28 представлена карта севера Красноярского края.

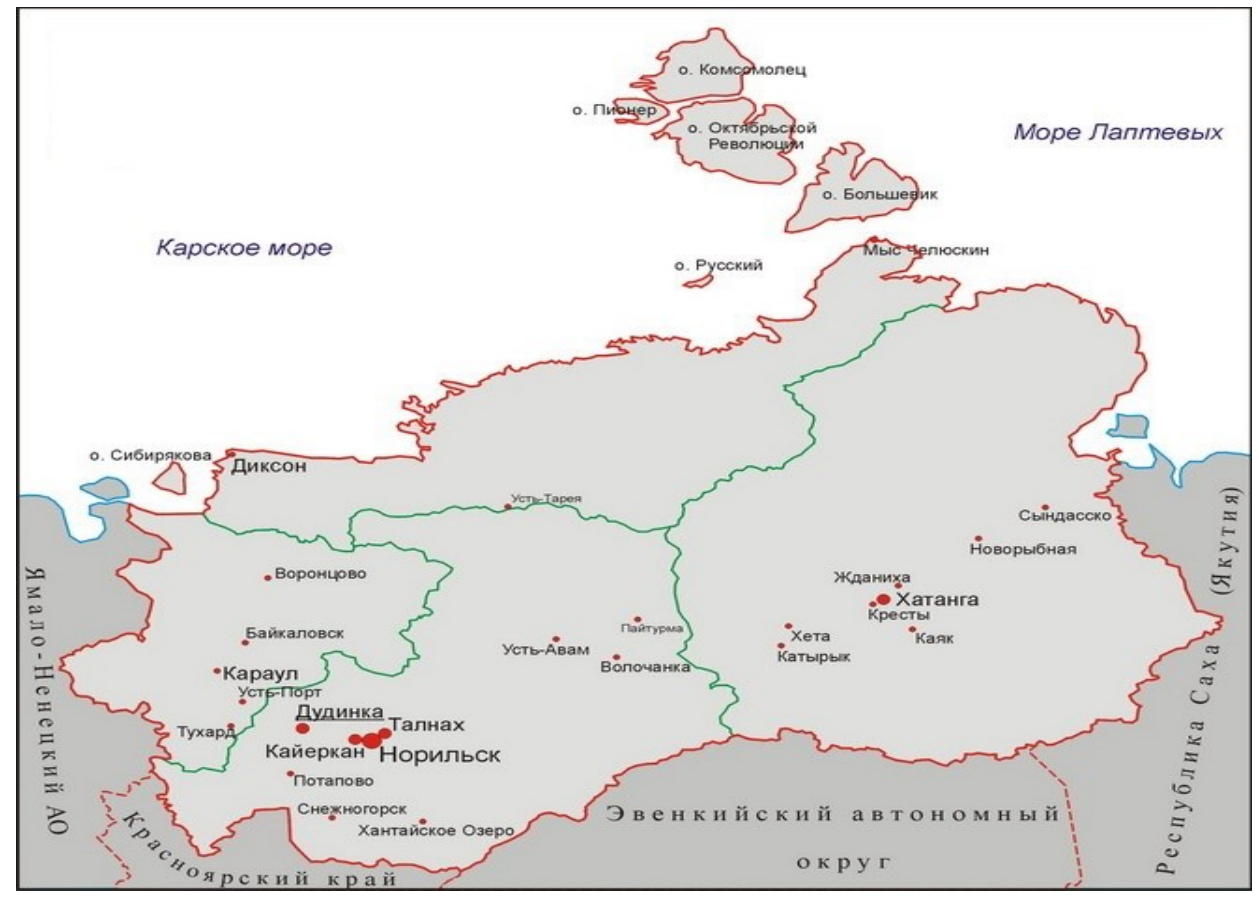

Рис. 28. Карта севера Красноярского края

Энергетика края обладает самым большим в России гидроэнергетическим потенциалом. На Енисее построены крупнейшие в мире гидроэлектростанции. На территории края находятся двадцать действующих и одна строящаяся электростанция.

21 августа 2009 г. началась промышленная эксплуатация Ванкорского нефтегазового месторождения, запасы нефти которого превышают 260 млн т, природного газа - около 90 млрд м ${ }^{3}$. Проектная мощность - 14 млн т нефти в год. По добыче нефти и газа Красноярский край в настоящее время занимает передовые позиции в Сибирском федеральном округе.

В крае ведут деятельность крупнейшие финансово-промышленные группы: «Базовый элемент», «РУСАЛ Красноярский алюминиевый завод», Ачинский глинозёмный комбинат, Красноярский ЦБК, «Интеррос», 
«Норильский никель», «Евраз», Краснокаменский и Ирбинский железные рудники, лесной комплекс, группа «МДМ» - СУЭК (добыча угля, энергетика).

Красноярский край является крупным транспортнораспределительным и транзитным узлом Сибирского федерального округа. Транспортный комплекс края представлен всеми видами транспорта, включая трубопроводный.

На юге края действует Транссибирская железнодорожная магистраль. На севере края есть Норильская железная дорога, проектируются СевероСибирская железнодорожная магистраль и Трансполярная магистраль на месте заброшенного участка Игарка - Долгий.

Водный транспорт в крае - это СМП и судоходство по Енисею («Енисейское речное пароходство»). Речные порты - Красноярский речной порт, Лесосибирский порт, Енисейский порт, морские порты в Игарке и Дудинке.

Развит авиатранспорт - двадцать шесть аэропортов, в том числе крупнейший международный аэропорт Емельяново в Красноярске.

Основным видом транспорта остаётся железная дорога.

С открытием алмазоносных месторождений на западе Республики Саха - Якутия была создана и существует сегодня очень мощная алмазодобывающая промышленная инфраструктура. Промышленность Якутии ориентирована на добычу и обогащение сырья, республика богата природными ресурсами. Здесь находится крупнейшее в стране Эльконское урановое месторождение с разведанными запасами около 370 тыс. т урана. Добывающая промышленность (алмазы, золото, нефть, газ, уголь и другие полезные ископаемые) развивается успешно.

В 2011 г. начата отгрузка угля с крупнейшего в России Эльгинского угольного месторождения в порты Хабаровского и Приморского краев для отгрузки в страны АТР.

Основная часть грузопотока приходится на водный транспорт. В период навигации основными транспортными артериями становятся реки (Лена с притоками Вилюй и Алдан, Индигирка, Колыма). В северные районы республики грузы доставляются по СМП.

Развивается автомобильная сеть республики. Открыта для круглогодичного движения на всём своём протяжении автодорога федерального значения «Колыма» (Якутск - Магадан). Автодорога федерального значения «Лена» связывает Якутск с общероссийской автомобильной сетью.

Развит воздушный транспорт. В республике 23 аэропорта.

Действует участок Амуро-Якутской железнодорожной магистрали Беркакит - Алдан - Томмот.

Основные отрасли промышленности Магаданской области горнодобывающая и рыбная. Горнодобывающая промышленность почти полностью сконцентрирована в Сусуманском и Омсукчанском районах. Область богата золотом, серебром, оловом, вольфрамом, встречаются медь, молибден, каменный уголь, нефть и газовый конденсат. По данным на ноябрь 2015 г., за год было добыто 22,8 т золота и 979,5 т серебра. Добычу золота в регионе на 2015 г. проводили 183 компании, из них 130 специализировались 
на россыпной золотодобыче. В 2016 г. магаданские недропользователи добыли 24,5 т золота и 1128 т серебра.

Рыбное хозяйство является второй по значимости отраслью, продукция поставляется на экспорт. Удельный вес рыбной отрасли в объеме производства области составляет $18 \%$, рыболовство и рыбная промышленность сосредоточены в городе Магадане.

Главные транспортные ворота области - Магаданский морской торговый порт, через который поступает основной поток грузов, осуществляются речные перевозки. Вблизи города Магадана находится аэропорт Магадан (Сокол), который принимает все типы пассажирских авиалайнеров и тяжёлые транспортные самолёты.

Основу экономики Чукотки составляет горнодобывающая промышленность. Промышленное освоение региона началось с конца 1950-х гг., с открытием богатых месторождений россыпного золота. По состоянию на 2018 г. на Чукотке добывается около 10 \% золота страны. Золотодобыча на территории округа ежегодно возрастала и достигла пика в 1974 г. (более 36 т) за счет освоения уникального по запасам месторождения на реке Рывеем. В последующие годы в связи с истощением россыпных запасов уровень добычи стал постепенно снижаться и до начала 1990-х гг. держался на уровне $15-19$ т.

В 2016 г. недропользователи Чукотского автономного округа увеличили добычу золота до 32,0 т, что на $29,8 \%$ больше, чем в 2013 г. Добыча серебра снизилась на 16,3 \%, до 138,45 т. Рудного золота добыто 29,7 т, россыпного - $2,3 \mathrm{~T}$.

Основные предприятия - ОАО «Чукотская ГГК» (в 2014 г. 22,5 из 29,7 т золота), ООО «Рудник Каральвеем» (производит порядка 1,5-2,0 т золота), ООО «Рудник Валунистый» (добывает порядка 1,0 т золота и 7 т серебра), ООО «ЗК Майское» (в 2014 г. произвело 5,8 т золота в концентрате).

Добычей золота из россыпей в 2014 г. занималось пятнадцать предприятий, лидер среди них - ООО «Артель старателей “Шахтёр"», которое произвело 611 кг золота (из 2285 кг).

За всё время промышленной разработки месторождений Чукотки было получено более 900 т золота, 200 тыс. т серебра.

Основные виды транспорта для дальних передвижений - морской и воздушный. Каждый город имеет свой аэропорт. Действуют пять федеральных морских портов СМП: Анадырь - крупнейший на Чукотке, Певек - самый северный российский порт, Провидения - пункт формирования караванов судов СМП, Беринговский - рейдовый, основной груз - добываемый вблизи уголь, Эгвекинот - самый северный порт Берингова моря.

Сегодня по СМП осуществляется транспортировка природных ресурсов, главным образом энергетических, в западном направлении, но планируется транспортировка СПГ в восточном направлении из порта Сабетта танкерами-газовозами Yamalmax усиленного ледового класса.

В транзитном отношении СМП будет интересен компаниям по доставке морепродуктов из Тихого океана в Европейскую часть России. В 2018 г. были доставлены 690 контейнеров с лососевыми в Санкт- 
Петербург. Для того чтобы доставить камчатскую рыбу, ее пришлось везти в порт Владивостока, так как на Камчатке нет причала, способного принять контейнеровозы на 12 тыс. контейнеров, и разгрузить их есть возможность только в Санкт-Петербурге. Снижение расходов на доставку морепродуктов может составлять до $30 \%$, при строительстве причалов для перегрузки в Петропавловске-Камчатском оно будет еще больше. Транзит грузов из стран АТР в Европу позволит сократить время в пути и расходы по доставке. При использовании эталонного маршрута Роттердам - Йокогама расстояние по СМП сокращается на 3860 морских миль, или на $34 \%$. Перевозки по СМП планируется к 2030 г. увеличить на 50 млн т.

Для обеспечения стабильного функционирования арктических морских коммуникаций необходима инфраструктура и ледокольный флот [59]. Реализация новых газовых и нефтегазовых проектов и развитие транзита по СМП для обеспечения круглогодичной проводки судов к 2030 г. потребуют построить не менее тридцати новых ледоколов различных классов [60].

Активность Китая в арктическом направлении объясняется не столько экономическим интересом к природным ресурсам, сколько политическим (геополитическим): контроль над коммуникациями Арктики и над перспективной магистралью для транспортировки китайских товаров в Европу.

\section{4. Инфраструктурное обеспечение военной безопасности Арктики}

Современная военно-стратегическая обстановка в Арктическом регионе характеризуется постепенным расширением зоны военной активности приарктических государств (США, Норвегии, Канады и Дании), которые стремятся в кратчайшие сроки зарезервировать за собой право на расширение зон национальной юрисдикции за счет континентального шельфа и островов акватории Северного Ледовитого океана. Они приступили к разработке и практической реализации концепций обеспечения своих интересов в регионе. При этом постоянное военное присутствие в Арктике и возможность защиты государственных интересов средствами вооруженной борьбы рассматривается ими как составная часть общей политики обеспечения национальной безопасности. Особое влияние на формирование арктической группировки Военно-морского флота оказывает процесс разграничения морского пространства Арктики, который принимает все более жесткий вид после заключения договора 2010 г. о разграничении спорного района Баренцева моря с Норвегией.

К проведению арктических исследований привлекаются надводные корабли и подводные лодки, корабли и суда береговой охраны, военная авиация, а также другие подразделения вооруженных сил заинтересованных стран - это позволяет совместить решение задач по освоению Арктики с демонстрацией национального флага. Перспективное развитие военнополитической обстановки в Арктике будет характеризоваться углублением региональных интеграционных процессов, дальнейшим сближением скандинавских и прибалтийских стран с США, ведущими западноевропейскими государствами и организациями, прежде всего в рамках НАТО и Европейского союза, и активизацией усилий Запада по созданию благоприятных условий для освоения ресурсов Арктики, в том 
числе в ущерб экономическим интересам России. Наиболее опасными представляются 2020-2025 гг., когда прогнозируется обвальное сокращение добычи нефти и газа в традиционных районах, а возникшие при этом острые противоречия в борьбе за ресурсы Арктики могут перерасти в военные действия.

Активизировалась деятельность ряда восточноазиатских государств по расширению своего влияния в Арктике в ущерб интересам Российской Федерации. С целью отстаивания общих интересов по обеспечению доступа к ресурсам Арктики, а также права свободного использования северных морских путей в 2004 г. создан и функционирует так называемый Азиатский форум полярных исследований (КНР, Япония, Южная Корея, Таиланд и Малайзия).

Таким образом, военная активность приарктических государств в Арктике создает угрозы национальной безопасности России, прежде всего военной безопасности, в Арктическом регионе среди которых: 1) усиление военного присутствия стран НАТО в Арктике и планируемое в связи с этим оборудование передовых пунктов базирования для защиты морских коммуникаций, а также развертывание систем освещения надводной и воздушной обстановки в Арктическом регионе; 2) рост боевых возможностей группировок коалиционных и национальных Вооруженных сил (Военноморских сил) США и НАТО; развитие систем противоракетной обороны морского базирования и раннего предупреждения; 3) рост активности спецслужб иностранных государств по ведению разведывательной деятельности в Арктике и на приграничной территории Российской Федерации; 4) развертывание и присутствие в Арктике в мирное время группировки Военно-морских сил НАТО, включающих надводные корабли, подводные лодки и авиацию военно-морских сил стран - участниц блока (Бельгии, Великобритании, Дании, Канады, Нидерландов, Норвегии, США, Франции и Германии); 5) проведение многонациональных военных учений и смещение районов боевой подготовки в арктическую зону; 6) увеличение военной спутниковой группировки США, нацеленной на Арктику; стремление норвежского руководства изменить статус архипелага Шпицберген как демилитаризованной зоны, сократить присутствие и в перспективе полностью вытеснить Российскую Федерацию с архипелага; 7) противодействие рыбопромысловой деятельности Российской Федерации в Норвежской экономической зоне путем ужесточения требований к рыболовным судам в районах промысла и неправомерных действий по отношению к ним со стороны норвежских властей; стремление ряда иностранных государств (США, Норвегии, Японии и Канады) придать СМП статус международной транспортной магистрали [28].

Таким образом, действия приарктических и других государств по наращиванию своего экономического и военного присутствия в Арктике объективно требуют от Российской Федерации принятия адекватных мер, направленных на поддержание паритета и создание благоприятных условий для реализации и защиты национальных интересов Российской Федерации в этом важном регионе. В целом современная военно-стратегическая обстановка в Арктике стабильная, контролируемая и прогнозируемая на среднесрочную перспективу. Российская Федерация обладает 
достаточным военным потенциалом для обеспечения военной безопасности в Арктике, способна развивать и наращивать его адекватно возникающим угрозам. В целях обеспечения контроля за обстановкой, своевременного выявления, предупреждения и предотвращения военных угроз в Арктике Министерством обороны России выполняется комплекс мероприятий, направленных на наращивание возможностей системы разведки и береговой системы наблюдения, а также развитие системы базирования Военноморского флота и Военно-воздушных сил в АЗРФ.

В этой связи следует положительно оценить решение о проведении в Санкт-Петербурге Международного военно-морского салона (МВМС), которое было принято на основании распоряжения Правительства Российской Федерации от 3 марта 2001 г. № 294-р. Его организаторами выступили Министерство промышленности и торговли Российской Федерации при участии Министерства обороны Российской Федерации, Министерство иностранных дел, Федеральная служба по военно-техническому сотрудничеству, Правительство СанктПетербурга, ФГУП «Рособоронэкспорт».

Известно, что для демонстрации достижений в области создания новых видов вооружения в мире проводится большое количество международных выставок, салонов и форумов. Самыми представительными и авторитетными являются международные выставки военно-морской и авиационной техники в Ле-Бурже (Франция), Абу-Даби (ОАЭ), «Аэрошоу Чайна» (Китай) и др. К ним следует отнести и МВМС в Санкт-Петербурге, который логично завершает создание в России выставочной инфраструктуры экспонирования и демонстрации вооружения и военно-морской техники.

Вслед за авиакосмическим салоном МАКС в подмосковном Жуковском, выставками вооружения и военной техники сухопутных войск в Омске и Нижнем Тагиле этот форум впервые в России наиболее полно представляет весь спектр военно-морской техники и оружия, технологий и услуг, предлагаемых российскими предприятиями и организациями оборонно-промышленного комплекса в этой области. МВМС проводится с 2003 г. и прочно занял место в первой тройке мировых выставок морских вооружений и техники. Высокие результаты и состав участников свидетельствуют о том, что МВМС сформировался как успешная выставка судостроительной промышленности, оборонно-промышленного комплекса, смежных отраслей и производителей материалов и комплектующих, позволяющая эффективно решать задачи по продвижению продукции и расширению кооперационных связей. Формат МВМС предоставляет возможность не только познакомиться с новейшими образцами военноморской техники, передовыми разработками в судостроении и смежных отраслях, но и увидеть корабли и катера, морское вооружение и авиацию в действии, провести встречи с партнерами, посетить предприятия, участвовать в переговорах, приемах и широкой научно-деловой программе.

Место проведения МВМС обеспечивает успешное представление экспозиции в павильонах и на открытых площадках, показ кораблей и катеров у причалов, демонстрацию гидроавиации и боевых самолетов над акваторией вблизи выставочных павильонов. Оно заслуженно признано лучшим в мире местом для проведения морских выставок. 
Сегодня в Санкт-Петербурге в сфере морской индустрии работают сорок предприятий и организаций, на которых трудятся тысячи специалистов высокого уровня; здесь сконцентрировано около 80 \% научно-технического потенциала судостроительной отрасли России. Современные боевые корабли, созданные в Северной столице, составляют основу морской мощи страны. Только в 2013 г. на петербургских верфях было заложено восемь новых кораблей и судов, десять спущено на воду, четырнадцать передано заказчику. После перевода в Санкт-Петербург главного командования Военно-морского флота Российской Федерации город по праву можно назвать военно-морской столицей России.

Экспозиционно-выставочный раздел организован на базе современного выставочного комплекса Санкт-Петербурга. Здесь предприятия экспонируют свою продукцию на стендах по одиннадцати тематическим направлениям - корабли и суда, силовые установки и энергетическое оборудование, вооружение и комплексы управления оружием, радиоэлектронное, радиотехническое и гидроакустическое оборудование, морская авиация, навигация и океанография, вооружение и техника береговых частей Военно-морского флота, инфраструктура обеспечения Военно-морского флота, поисково-спасательное оборудование, система подготовки кадров для Военно-морского флота, новые технологии и материалы. Демонстрационный раздел организует показ таких кораблей, как эскадренный миноносец, малый ракетный и сторожевой корабли, базовый тральщик, малый десантный корабль на воздушной подушке, ракетные и патрульные катера и другие. Посетителям предоставляется возможность присутствовать при проведении стрельб и убедиться в высоких боевых характеристиках артиллерийских систем. Предусмотрена возможность проведения научно-технических конференций, организатором которой выступает всемирно известный Центральный научно-исследовательский институт им. А. Н. Крылова. Также возможно ознакомление потенциальных заказчиков с производственной и испытательной базами ведущих предприятий и организаций Санкт-Петербурга. МВМС за период 2003-2015 гг. посетили официальные делегации более чем из пятидесяти стран. Его участниками явились сотни предприятий, институтов и организаций, в том числе из ближнего и дальнего зарубежья (табл. 11).

Весной 2009 г. на выставке оборонных систем в Азии ОКБ «Новатор» впервые представило ракетную систему с крылатой ракетой «Калибр-К». В нее входят четыре такие морские ракеты. Ракетный комплекс «Калибр» смотрится, как обычный двенадцатиметровый грузовой контейнер, который используют для перевозок. Такая маскировка помогает комплексу быть незамеченным до момента активации. Высокоточная крылатая ракета «Калибр» 3М-14Э предназначена для поражения в простых и сложных метеоусловиях днем и ночью стационарных (малоподвижных) наземных и морских целей. Типовыми целями для ракеты $3 \mathrm{M}-14$ Э являются наземные пункты управления войсками, склады вооружений и топлива, аэродромные и портовые сооружения. По боевому назначению крылатая ракета «Калибр» имеет три варианта - противокорабельная, противолодочная и высокоточная ракета для уничтожения стационарных наземных целей. 
Таблииа 11

Основные показатели военно-морских салонов за период 2003-2015 гг.

\begin{tabular}{|c|c|c|c|c|c|c|}
\hline & \multirow{2}{*}{$\begin{array}{c}\text { Число } \\
\text { Год }\end{array}$} & \multicolumn{5}{|c|}{ участников / } \\
\cline { 3 - 7 } & иностранных & павильонов & кораблейй & $\begin{array}{c}\text { посетителей / } \\
\text { специалистов }\end{array}$ & $\begin{array}{c}\text { иностранных } \\
\text { участников / } \\
\text { стран }\end{array}$ & мероприятий \\
\hline 2003 & $319 / 52$ & 12043 & 19 & $9000 / 3980$ & $26 / 24$ & 10 \\
\hline 2005 & $352 / 56$ & 12043 & 19 & $9800 / 4300$ & $28 / 26$ & 17 \\
\hline 2007 & $383 / 64$ & 12500 & 8 & $11600 / 5100$ & $50 / 44$ & 8 \\
\hline 2009 & $340 / 70$ & 13000 & 12 & $12300 / 5600$ & $55 / 47$ & 12 \\
\hline 2011 & $400 / 69$ & 14500 & 20 & $12500 / 6400$ & $45 / 39$ & 18 \\
\hline 2013 & $457 / 84$ & 17000 & 15 & $18000 / 9600$ & $56 / 42$ & 25 \\
\hline 2015 & $424 / 46$ & 17500 & 39 & $19000 / 9800$ & $46 / / 9$ & 24 \\
\hline
\end{tabular}

Запускается ракета из универсального стартового модуля, который может располагаться вертикально под палубой корабля, наклонно на палубе корабля, в торпедном аппарате подводной лодки. Диаметр пускового устройства равен пятьсот тридцать три миллиметра и соответствует диаметру итальянского торпедного аппарата. Дело в том, что до Великой Отечественной войны Советский Союз купил в Италии образцы торпед, и вот теперь диаметры наших пусковых установок привязаны к мировым стандартам. Все варианты, кроме авиационного, имеют стартовый ускоритель твёрдого топлива. Система наведения 3М-14Э комбинированная инерциальная с возможностью уточнения текущего положения через спутниковую систему навигации плюс радио высотомер. Полёт происходит по заданному маршруту на высоте 20 м над морем и от 50 до 150 м над сушей. Высота полёта над сушей зависит от профиля местности. Сам маршрут может быть составлен по сложной схеме с обходом зон противовоздушной обороны противника. В заданной точке ракета пикирует на цель или производит воздушный подрыв боевой части. У противокорабельной ракеты наведение на конечном участке траектории осуществляется при помощи защищённой от помех активной радиолокационной головки самонаведения.

7 октября 2015 г. произошло событие, всю важность которого едва ли можно оценить с первого взгляда. Группа кораблей Каспийской флотилии Военно-морского флота Российской Федерации (сторожевой корабль «Дагестан» и малые ракетные катера «Град Свияжск», «Углич» и «Великий Устюг») нанесли удар по исламистам в Сирии крылатыми ракетами «Калибр» (модификацией 3М-14 с дальностью 1500 км), которые пересекли территорию трёх стран - Ирана, Ирака и, собственно, Сирии, после чего поразили одиннадцать целей. Случай если не беспрецедентный, то крайне редкий в современной истории. Без ложной скромности можно говорить, что Россия реализовала американскую концепцию «глобального удара» раньше самих США.

В период с 1 по 5 июля 2015 г. В Санкт-Петербурге проходил VII MBMC, в котором приняли участие 46 официальных делегаций из 39 государств, где были представлены практически все страны, занимающиеся производством и эксплуатацией морской техники. В составе 
делегаций прибыли два заместителя министров обороны, девять главнокомандующих военно-морскими силами и другие высокопоставленные официальные лица. Обширная программа работы делегаций выполнена полностью, ее формат и объем превысили аналогичные показатели предыдущих салонов.

Официальные иностранные делегации посетили ФГУП «Крыловский государственный научный центр», ОАО «Северное ПКБ», ОАО «ЦМКБ “Алмаз"», ОАО «Адмиралтейские верфи», ОАО «Судостроительный завод “Северная верфь”», ОАО «Концерн “ЦНИИ «Электроприбор»”», ООО «Балтийский завод - Судостроение» и ОАО «Средне-Невский судостроительный завод». Было проведено более восьмидесяти официальных переговоров с участием главнокомандующего Военно-морского флота Российской Федерации, должностных лиц Федеральной службы по военнотехническому сотрудничеству России, представителей ОАО «Рособоронэкспорт» и АО «ОСК».

Результаты салона свидетельствуют, что российские и зарубежные предприятия ведут активную маркетинговую политику, направленную на расширение своего участия в международной кооперации, связанной с разработкой и производством таких сложных технических систем, как боевые корабли. Информационное сопровождение и организацию прессцентра МВМС - 2015 осуществлял Санкт-Петербургский региональный информационный центр ТАСС, работу салона освещали 467 журналистов из 153 средств массовой информации.

В работе МВМС - 2015 приняли участие свыше 43 тыс. специалистов. С учетом связи многих жителей Санкт-Петербурга с морской отраслью, патриотических традиций и интереса к событию, жителям и гостям города была предоставлена возможность посетить экспозицию, увидеть боевые корабли у причалов и посмотреть демонстрационные полеты авиационных групп высшего пилотажа «Русские витязи», «Стрижи» и «Русь», а также показательные выступления парашютно-десантной службы 118-го отдельного учебного центра специального назначения.

VIII Международный военно-морской салон проходил на фоне возрастающего внимания руководства страны и Минобороны к военному флоту, причем особое внимание было уделено вопросам, связанным со строительством объектов инфраструктуры для Военно-морского флота и выполнением гособоронзаказа в сфере поставки новых кораблей и судов. В настоящее время работы по созданию и развитию флотской инфраструктуры ведутся на шестнадцати площадках в восьми пунктах базирования. Их поэтапное выполнение позволяет вводить в действие первоочередные объекты, обеспечивающие прием и эксплуатацию поступающего вооружения и военной техники. 


\section{ГЛАВа 5. ИНФРАСТРУКТУРНЫЕ ПРОЕКТЫ КАК ЭЛЕМЕНТЫ ПРОМЫШЛЕННОЙ ПОЛИТИКИ АРКТИЧЕСКОГО РЕГИОНА}

\section{1. Промышленная политика арктического региона}

Проведенный нами анализ научной литературы и нормативноправовых актов показал, что поскольку промышленную политику чаще всего трактуют как некую совокупность мер (мероприятий) или действий по развитию промышленного производства, то происходит, во-первых, отождествление политики с программой или комплексным планом; во-вторых, практически становятся неразличимыми цели промышленной политики и цели промышленного развития, с чем нельзя согласиться.

Можно согласиться с позицией, определяющей сущность экономики региона как постоянно воспроизводимую целостность производительных сил (работников, средств и предметов труда) и экономических отношений между работниками в следующих сферах хозяйства региона: сфере материального производства, социальной сфере и природоформирующей сфере. Тогда под промышленным сектором экономики макрорегиона можно понимать воспроизводственную целостность совокупности производительных сил и экономических отношений в сфере промышленного производства между заинтересованными субъектами и объектами хозяйствования, результатом которых являются товары на различных стадиях готовности.

Под понятием «развитие промышленного сектора экономики макрорегиона» следует понимать процесс трансформации промышленного производства, перехода его от сложившегося к новому качественному состоянию, которое может быть достигнуто разными способами, и не всегда это означает рост ВРП (например, изменения в характеристиках рабочей силы и др.). Другими словами, развитие промышленности макрорегиона можно определить как комплексный процесс трансформации элементов сферы его промышленного производства, приводящий к качественным преобразованиям в промышленности макрорегиона и в конечном счете к позитивным результатам изменений в его экономической, социальной и природной сферах.

Определяя государственную промышленную политику на макроуровне как совокупность намерений и действий субъектов, реализующих интересы государства в отношении промышленного развития макрорегиона, а также экономические интересы самого макрорегиона, муниципальных структур управления и крупных промышленных предприятий в сфере перспективного развития промышленного производства в макрорегионе, рассмотрим вопросы соотношения целей промышленной политики и промышленного развития. За определение цели примем идеальный или реальный предмет сознательного или бессознательного стремления субъекта; конечный результат, на который преднамеренно направлен процесс [25]. Другими словами, цель представляет собой желаемый результат сознательного стремления субъекта. 
Развитие промышленности в пределах макрорегиона есть объект государственной промышленной политики, которая выступает в качестве ведущего инструмента государственного регулирования изменений в рассматриваемой сфере. Поэтому представляется очевидным, что цели развития промышленности в макрорегионе и цели государственной промышленной политики на макроуровне отличны по своей природе, ибо в основе их лежат экономические интересы различных субъектов. Ведь в современных условиях хозяйствования цели развития промышленности в макрорегионе реализуют, главным образом, экономические интересы владельцев и топ-менеджмента предприятий, в первую очередь крупных, определяющих состояние местного рынка труда, формирующих доходную часть региональных бюджетов.

Что касается субъекта государственной промышленной политики на макроуровне, то, как отмечалось, он имеет сложную структуру; ядро его составляет подразделение региональной администрации, ответственное за решение проблем развития промышленности в регионах. Кроме того, субъект государственной промышленной политики на макроуровне включает так называемые субъекты влияния, среди которых федеральные структуры, структуры местного самоуправления (на их территории и происходит промышленное развитие и потребление местных ресурсов), а также другие субъекты управления и хозяйствования, имеющие экономические интересы в развитии промышленного производства в макрорегионе. Отмеченные структуры воздействуют на развитие промышленного сектора экономики макрорегиона, участвуют в проведении государственной промышленной политики.

Субъект промышленного развития макрорегиона, как и субъект государственной промышленной политики на макроуровне, сложен по своей структуре и включает субъекты, входящие в систему цепочки ценностей промышленного предприятия (поставщиков, контрагентов, потребителей), которые могут быть представителями различных сфер деятельности промышленного сектора экономики макрорегиона, зачастую находящимися вне рамок макрорегиона, страны (табл. 12).

Данные табл. 12 свидетельствуют о сложности формирования целей промышленной политики и целей развития промышленности в макрорегионе, что обусловлено: во-первых, возможными противоречиями между экономическими интересами (а значит, и целями) субъектов государственной промышленной политики и субъектов развития промышленного производства в макрорегионе; во-вторых, противоречиями между экономическими интересами объектов хозяйствования и субъектов государственного регулирования промышленного развития в макрорегионе; в-третьих, поскольку объектом государственной промышленной политики как инструмента государственного регулирования развитием промышленного сектора экономики макрорегиона выступает процесс развития промышленности макрорегиона, то могут иметь место противоречия между целями государственной промышленной политики и целями развития промышленности макрорегиона в целом. 
Характеристика основных категорий государственной промышленной политики на макроуровне

\begin{tabular}{|c|c|c|c|}
\hline Категория & $\begin{array}{c}\text { Государственная } \\
\text { промышленная политика }\end{array}$ & $\begin{array}{c}\text { Развитие } \\
\text { промышленности } \\
\text { макрорегиона } \\
\end{array}$ & Примечание \\
\hline Сущность & $\begin{array}{l}\text { Система намерений и } \\
\text { действий субъектов, } \\
\text { реализующих интересы } \\
\text { государства в отношении } \\
\text { макрорегиона, внутренние } \\
\text { интересы самих регионов, } \\
\text { интересы муниципальных } \\
\text { органов управления и } \\
\text { крупных промышленных } \\
\text { предприятий по проблемам } \\
\text { развития промышленного } \\
\text { производства в } \\
\text { макрорегионе }\end{array}$ & $\begin{array}{l}\text { Комплексный процесс } \\
\text { изменения элементов } \\
\text { сферы материального } \\
\text { производства, } \\
\text { приводящий к } \\
\text { качественным } \\
\text { преобразованиям в } \\
\text { промышленности } \\
\text { макрорегиона }\end{array}$ & $\begin{array}{l}\text { Различная природа } \\
\text { и исходные } \\
\text { предпосылки }\end{array}$ \\
\hline Объект & $\begin{array}{l}\text { Развитие промышленного } \\
\text { производства в } \\
\text { макрорегионе }\end{array}$ & \begin{tabular}{|l} 
Производство \\
конкурентоспособных \\
промышленных \\
товаров \\
\end{tabular} & $\begin{array}{l}\text { Различная природа } \\
\text { объектов }\end{array}$ \\
\hline Субъект & $\begin{array}{l}\text { Сложная структура: } \\
\text { субъекты на различных } \\
\text { уровнях }\end{array}$ & $\begin{array}{l}\text { Сложная структура: } \\
\text { субъекты, входящие в } \\
\text { систему цепочки } \\
\text { ценностей } \\
\text { промышленного } \\
\text { предприятия, зачастую } \\
\text { выходящие за рамки } \\
\text { макрорегиона } \\
\end{array}$ & $\begin{array}{l}\text { Различные } \\
\text { субъекты, но есть } \\
\text { общие - ведущие } \\
\text { промышленные } \\
\text { предприятия } \\
\text { макрорегиона }\end{array}$ \\
\hline $\begin{array}{l}\text { Факторы } \\
\text { воздействия }\end{array}$ & Внешние и внутренние & $\begin{array}{l}\text { Внешние и } \\
\text { внутренние }\end{array}$ & $\begin{array}{l}\text { Требуют } \\
\text { исследования } \\
\text { и классификации } \\
\text { по объектам, } \\
\text { характеру, величине } \\
\text { и направлениям } \\
\text { воздействия }\end{array}$ \\
\hline Цели & $\begin{array}{l}\text { Отражают интересы } \\
\text { субъектов }\end{array}$ & $\begin{array}{l}\text { Отражают интересы } \\
\text { субъектов }\end{array}$ & $\begin{array}{l}\text { Требуют } \\
\text { согласования - } \\
\text { гармонизации }\end{array}$ \\
\hline
\end{tabular}

При этом следует отметить, что противоречия целей промышленной политики и целей развития промышленного производства в макрорегионе могут быть следствием расхождения экономических интересов внутри субъекта государственного регулирования развития промышленного сектора экономики макрорегиона и субъекта возможных противоречий целей 
субъектов и противоречий между целями субъектов и объектов. Поскольку не всегда и не все цели могут быть различными, возможны следующие противоречия: 1) между целями государственной промышленной политикой и целями развития промышленности макрорегиона; 2) между целями субъектов и объектов государственной промышленной политики; 3) между целями субъектов и объектов развития промышленного производства в макрорегионе; 4) между целями субъектов государственной промышленной политики и целями субъектов развития промышленности в макрорегионе.

Противоречия между целями как объекта и субъекта государственной промышленной политики, так и развития промышленности макрорегиона возникают, поскольку, с одной стороны, есть устремление объекта, отражающее направленность деятельности, а с другой - есть цель субъекта, которая должна быть конкретна и достижима, по ней оценивается результативность воздействия на объект. Чем больше совпадают цели субъекта и объекта, тем эффективнее деятельность. Противоречие между целями субъекта и объекта государственной промышленной политики и целями развития промышленности макрорегиона (ситуация, когда при достижении цели объектом невозможно достичь цели субъекта) усложняет или сводит на нет все усилия. Оно возникает по причине различных интересов этих субъектов. Так, например, промышленное предприятие как субъект чаще всего имеет целью получение прибыли и в соответствии с этой целью проводит оптимизацию ресурсов, в том числе и персонала, для сокращения затрат. При этом на уровне регионального управления может быть поставлена цель создания дополнительных рабочих мест в промышленности. Такая ситуация может быть связана, например, с реализацией общегосударственной политики в регионе.

В процессе формирования цели существует два основных вида ее постановки - прямая и опосредованная. В первом случае сначала ставится цель, затем определяются способы её достижения; во втором - наличествует некоторый протекающий процесс, субъект которого формирует состояние объекта процесса, которое определяется как удовлетворяющее смыслу процесса. Тогда это состояние называется целью процесса. Для целей государственной промышленной политики и целей развития промышленности в макрорегионе в большей мере подходит опосредованный процесс формирования целей [25].

Что касается целей развития промышленного производства в макрорегионе, то можно согласиться с мнением группы авторов [61], что основные этапы процесса их формирования на долгосрочную перспективу следующие: 1) формирование сценарных условий перспективного промышленного развития макрорегиона, включающее функции стратегического анализа основных факторов, определяющих это развитие; его стратегический выбор; стратегическое позиционирование, формирование собственно сценарных условий его долгосрочного промышленного развития; 2) сценарное планирование перспективного экономического развития макрорегиона, включающее генерацию и анализ основных возможных сценариев развития его экономики, определяемых влиянием факторов внешнего и внутреннего порядков; разработку основных параметров долгосрочного прогноза целевых показателей, соответствующего принятым 
сценариям регионального экономического развития; 3) формулирование целей промышленного развития макрорегиона; 4) гармонизация целей промышленного развития и целей государственной промышленной политики.

Концептуально процесс формирования сценарных условий развития регионов Арктики представлен на рис. 29.

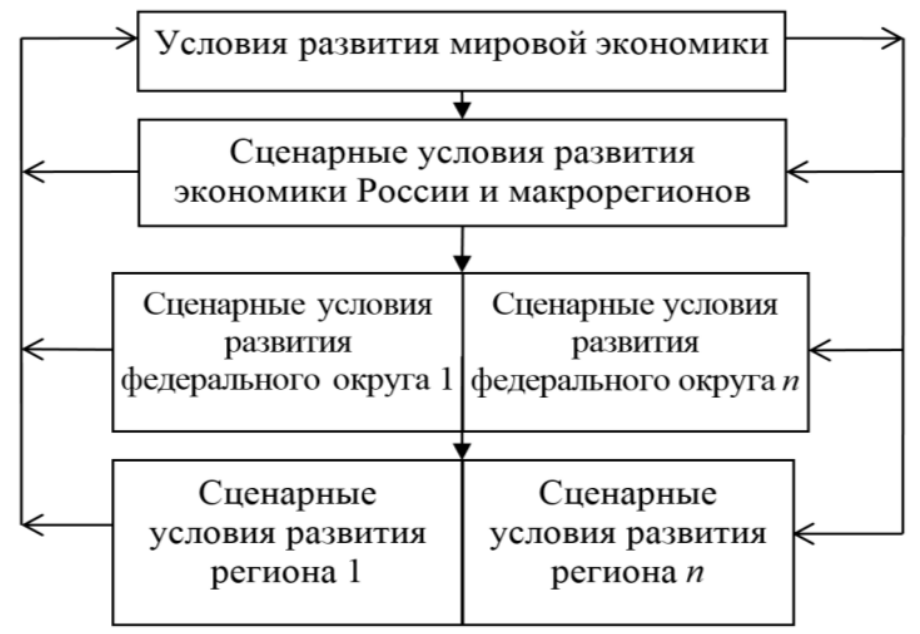

Рис. 29. Процесс формирования сценарных условий регионов Арктики [18]

Северные регионы относятся к различным федеральным округам $(1,2 \ldots n)$, каждый из которых имеет свои сценарные условия; каждый регион Арктики, в свою очередь, имеет собственные сценарии развития, отличающиеся от других регионов.

Как уже отмечалось выше, АЗРФ в нашем рассмотрении представлена рядом субъектов Федерации, каждый из которых имеет свою структуру управления, относится к определенному федеральному округу. Административно она выделена недавно, в результате отсутствует структура управления. Регионы, входящие в состав АЗРФ, относятся к различным федеральным округам, в результате возникают разные цели и задачи промышленного развития, не всегда согласующиеся между собой, а следовательно, имеются и разные сценарии.

Совместная политика промышленного развития субъектов Арктического региона позволила бы координировать мероприятия, повышающие мобильность факторов производства и их использование как в самом макрорегионе, так и за его пределами.

Концептуально, процесс формирования сценариев развития субъектов Арктического макрорегиона представлен на рис. 30 в виде дерева логически выстроенных цепей, отражающих возможные пути развития региона с учетом сценариев развития объектов более высокого уровня.

При наличии только одного (условно) сценария развития мировой экономики получается множество вариантов развития отдельных регионов АЗРФ. При этом сценарий развития макрорегиона является приоритетом (CMP). 


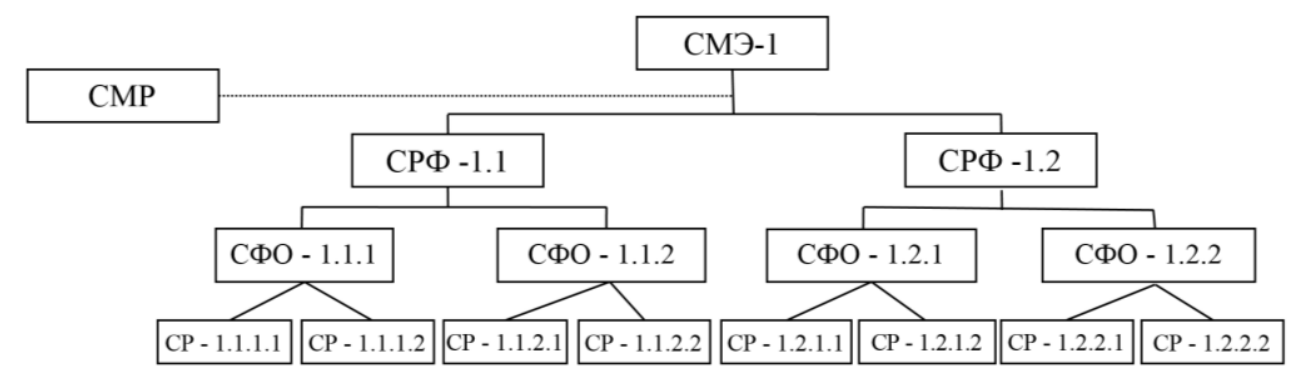

Рис. 30. Формирование сценариев развития макрорегиона [18]:

СМЭ - сценарии развития мировой экономики; СРФ - сценарии развития российской экономики; СФО - сценарии развития федерального округа; СР сценарии развития региона; СMP - сценарий развития макрорегиона

Представленная схема иллюстрирует недостатки действующей системы сценарного прогнозирования, в которой, во-первых, на каждом уровне рассматривается 2-3 сценария (в зависимости от уровня), во-вторых, отсутствует уровень федерального округа. В результате существующие сценарии развития региона отражают только отдельные варианты развития, при этом упускаются потенциальные возможности и не учитываются потенциальные угрозы.

Последовательность этапов процесса разработки целей промышленного развития представлена на рис. 31 .

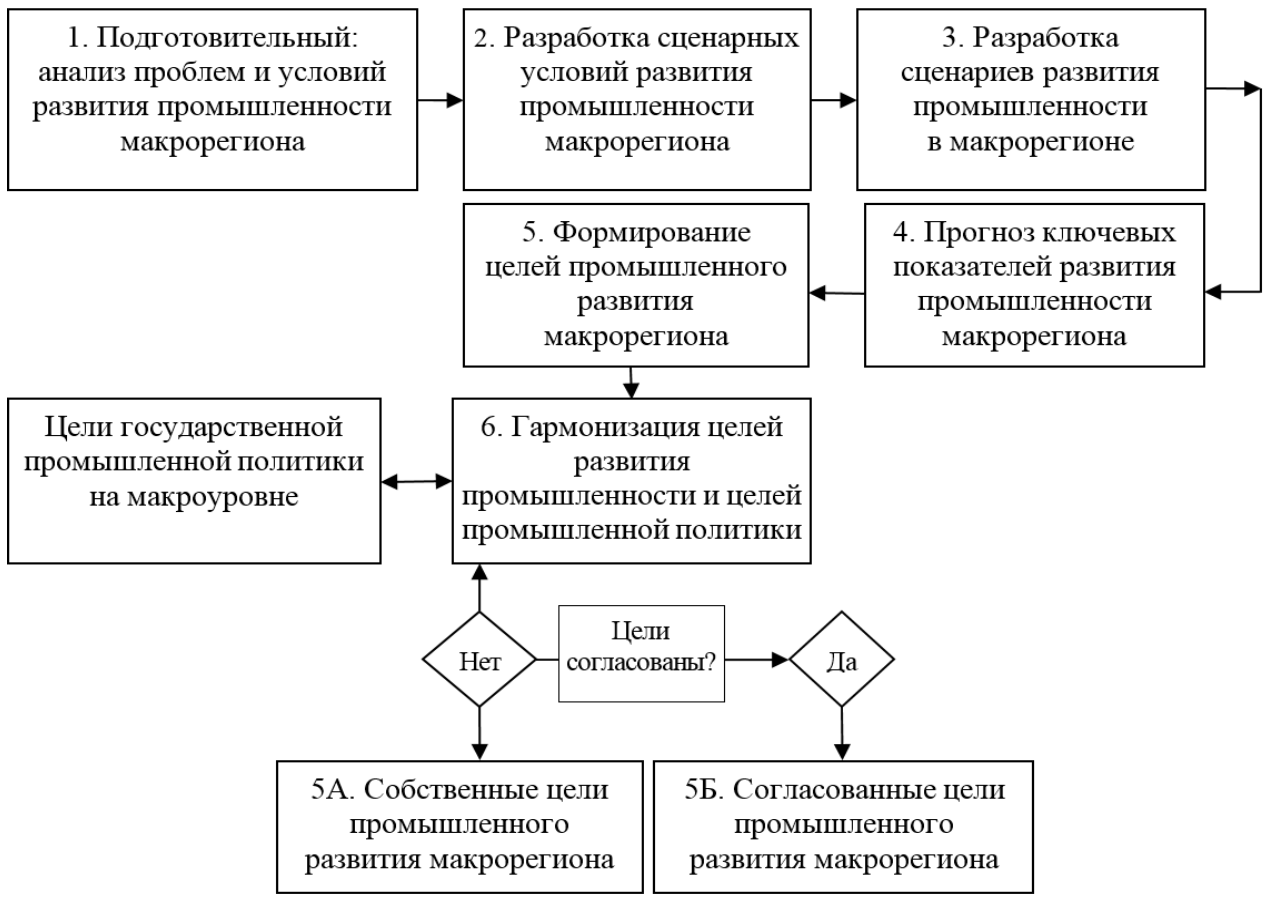

Рис. 31. Процесс разработки целей промышленного развития макрорегиона 
Из-за сложного представления субъекта политики цели должны формироваться на условиях гармонизации целей ее субъектов, при этом имеется совпадение отдельных субъектов региональной промышленной политики и целей развития промышленности региона (промышленные предприятия) (рис. 31).

В соответствии с Федеральным законом № 488-Ф3 «О промышленной политике в Российской Федерации» от 31 декабря 2014 г. [68], целями общегосударственной промышленной политики являются: 1) формирование высокотехнологичной, конкурентоспособной промышленности, обеспечивающей переход экономики государства от экспортно-сырьевого типа развития к инновационному [69]; 2) обеспечение обороны и безопасности государства; 3) обеспечение занятости населения и повышение уровня жизни граждан Российской Федерации.

При этом на региональном уровне, а также на уровне местного самоуправления и других субъектов хозяйствования перечень целей может и должен отличаться, что связано с наличием других интересов и намерений (соответствующих или дополняющих, а возможно, и противоречащих). Например, на уровне промышленного предприятия - это повышение прибыли, на уровне местного самоуправления - наполняемость бюджета и обеспечение социальных программ и т. д.

Безусловно, цели промышленной политики различных уровней (федерального, федеральных округов, субъекта Федерации, муниципального) могут и / или должны отличаться. Однако формирование целей региональной промышленной политики должно опираться на финансовые возможности соответствующих территориальных образований. Определять цели первого уровня только для федеральной промышленной политики, второго - для федерального округа, третьего - для субъекта Федерации, четвертого - для уровня местного самоуправления, пятого - для субъектов хозяйствования и т. д. не совсем верно. В данном случае все уровни целей (федеральный, федеральный округ, субъект Федерации, местный и уровень промышленных предприятий) должны быть обозначены в законах о промышленной политике на всех уровнях. Соотношение между целями (структура целей) может и должно отличаться (на уровне субъекта Федерации - доминирование целей регионального уровня).

В целом методология определения целей государственной промышленной политики заключается в выявлении и гармонизации экономических интересов ее субъектов, и на этой основе идет определение целевых установок в сфере регулирования промышленным развитием макрорегиона, а затем и самих целей.

Однако практическая реализация при этом осложняется, во-первых, неоднородностью властных структур (их отдельные группы имеют различные экономические интересы), во-вторых, существованием влиятельных субъектов управления и хозяйствования (в том числе за рубежом), не входящих формально в субъекты, но имеющих свои интересы в развитии промышленности макрорегиона.

Поэтому возникает весьма сложная задача выяснения истинных, зачастую противоречивых, экономических интересов субъектов промышленной политики на макроуровне, их гармонизации. При этом 
приоритеты промышленной политики на макроуровне должны вытекать из результатов гармонизации намерений и интересов субъектов промышленной политики в макрорегионе, т. е. достигнутый уровень согласования намерений и интересов субъектов промышленной политики на макроуровне является главным критерием выстраивания ее приоритетов. На рис. 32 представлена схема взаимодействия объектов и субъектов государственной промышленной политики.

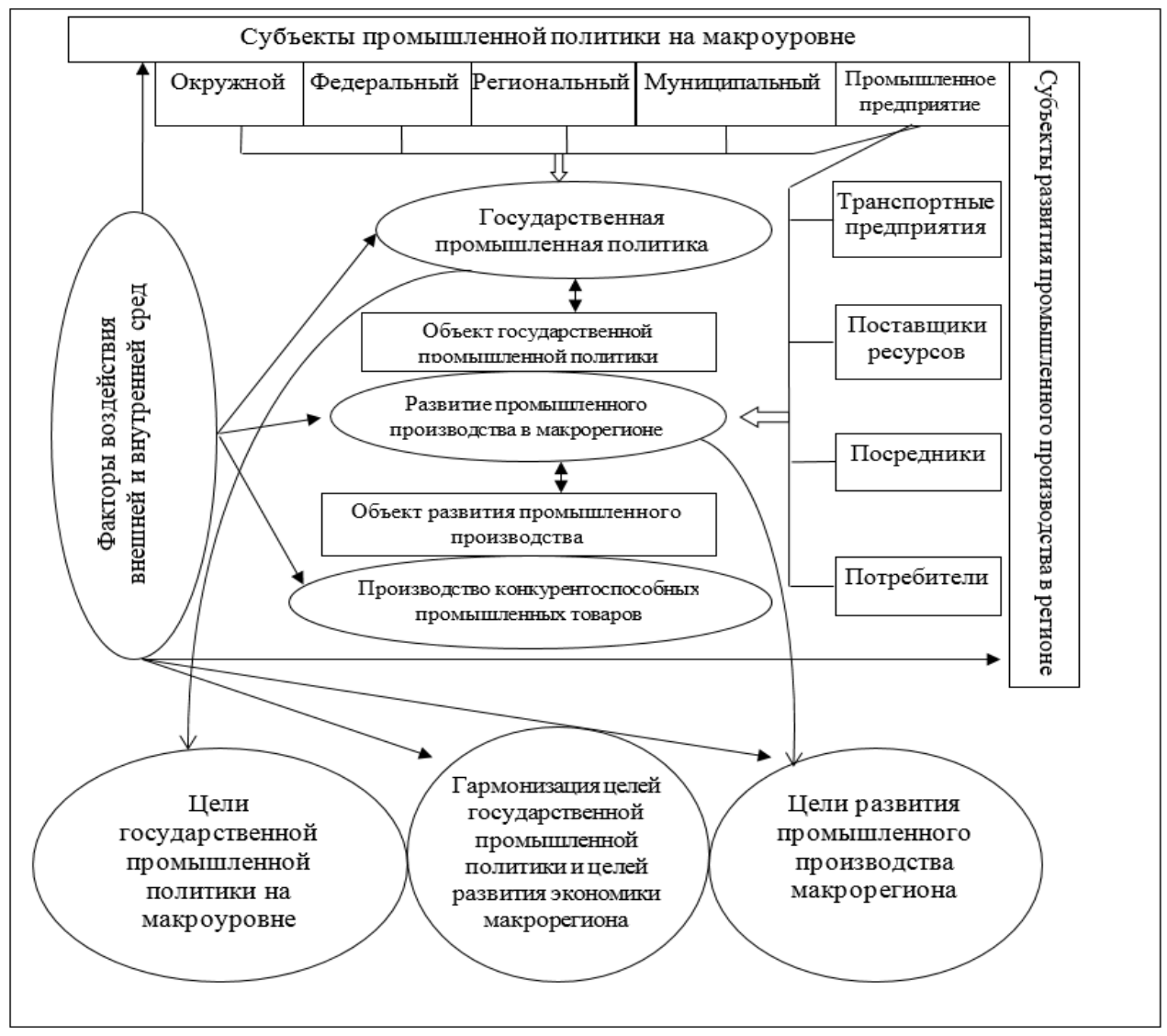

Рис. 32. Взаимодействие объектов и субъектов государственной промышленной политики и развития промышленного производства

Основные приоритеты в развитии государственной промышленной политики в Арктическом макрорегионе с позиции уровневого и локального подходов представлены в табл. 13, в которой выделены зоны приоритетов функциональной политики на каждом уровне, при этом мы полагаем, что пространственная, структурная и инновационная зоны имеют приоритетный характер при разработке и реализации промышленной политики на макроуровне. 
Приоритеты промышленной политики с позиции уровневого и функционального подходов

\begin{tabular}{|l|l|l|l|l|l|l|}
\hline \multirow{2}{*}{ Локальные политики } & \multicolumn{5}{|c|}{ Уровень политики } \\
\hline & глобальный & федеральный & федеральный округ & региональный & местный & корпоративный \\
\hline Пространственная & & & & & \\
\hline Финансовая & & & & & \\
\hline Инвестиционная & & & & & \\
\hline Бюджетная & & & & & \\
\hline Налоговая & & & & & \\
\hline Инновационная & & & & & \\
\hline Социальная & & & & & \\
\hline Экологическая & & & & & \\
\hline Структурная & & & & & \\
\hline Конкурентная & & & & & \\
\hline Кластерная & & & & & \\
\hline Инфраструктурная & & &
\end{tabular}


Анализ представленных выше данных позволил изучить взаимодействие объектов и субъектов государственной промышленной политики и развития промышленного производства и сделать вывод о том, что приоритеты промышленной политики на макроуровне должны вытекать из результатов гармонизации намерений и интересов субъектов промышленной политики в регионе. Кроме того, исследован процесс формирования цели промышленной политики и предложен процесс формирования сценарных условий развития субъектов Арктического макрорегиона, сделаны выводы о том, что пространственная, структурная и инновационная политики имеют приоритетный характер при разработке и реализации промышленной политики на макроуровне.

\section{2. Разработка и реализация промышленной политики}

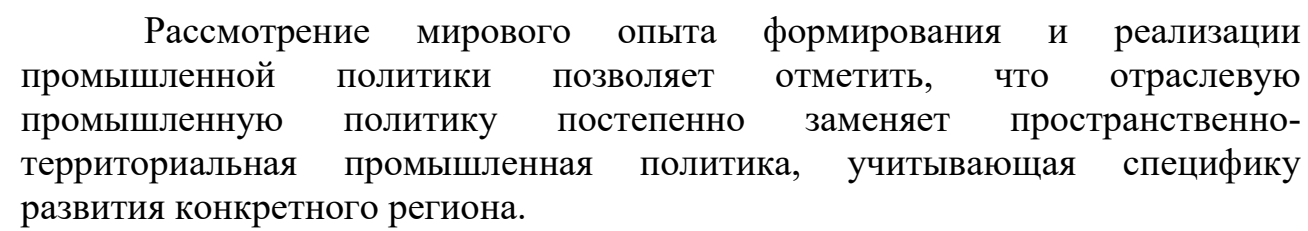

Непространственной региональной промышленной политики в принципе не может быть, так как она всегда сконцентрирована в рамках определенного региона, соответственно, пространственный фактор, несомненно, окажет воздействие на процессы развития региона.

На основе определения региональной промышленной политики, представленного в предыдущем разделе, определим сущность пространственной государственной промышленной политики на макроуровне как систему намерений и действий субъектов, реализующих интересы государства в отношении территории со схожей социально-экономической средой и природно-климатическими условиями, внутренние интересы самих регионов, входящих в пространство, интересы муниципальных органов управления и крупных промышленных предприятий по проблемам развития промышленного производства в определенном пространстве.

Пространственная государственная промышленная политика является одним из видов государственной промышленной политики, соответственно, вся общая методология, которая разработана для промышленной политики на макроуровне, представленная в предыдущем разделе, распространяется и на данный вид.

Принципы пространственной промышленной политики на макроуровне должны отражать специфику пространства. Рассматривая АЗРФ как единое пространство, обозначим следующие принципы пространственной промышленной политики.

1. Принцип целостности. Формирование структуры системы стратегического развития промышленного сектора арктического пространства, которая позволила бы разработать совокупность увязанных по вертикали и горизонтали стратегических документов. В данном случае синергетический эффект будет обусловлен взаимоувязкой стратегических решений, разработанных и на разном уровне иерархии власти, и в различных регионах, входящих в арктическое пространство. 
2. Принцип системности, который означает постановку целей и решение задач промышленного развития арктического пространства в контексте интересов участников процесса преобразований в сфере государственной промышленной политики, расположенных в различных регионах выделенного пространства.

3. Принцип инновационности, т. е. приоритет развития наукоемких, высокотехнологичных отраслей ввиду дефицита трудовых ресурсов, т. е. более полное использование фактора знания.

4. Принцип эффективности.

Таким образом, учет пространственного аспекта промышленной политики для АЗРФ позволит избежать противоречий между отдельными субъектами и всей Арктикой как единым пространством.

Современная государственная промышленная политика все больше превращается в средство реализации геоэкономических интересов определённых государств и надгосударственных образований. Новое геоэкономическое - измерение процессов регионального промышленного развития полностью изменяет назначение его институциональной структуры, представления о направлениях развития, отношениях между внутренней и внешней политикой, приводит к рассмотрению нового набора инструментов.

Упор федеральной власти на наиболее успешно ассимилировавшихся к условиям глобального рынка субъектов - крупные корпорации - как на локальных девелоперов не оправдывается. Крупные российские корпорации трансформируются в транснациональные, становясь неподконтрольными. Сохранение существующей пространственной структуры страны по производственно-технологическому принципу стало невозможным, когда национальную экономику открыли и последовала интеграция России в глобальный рынок. В связи с этим неэффективным пространственным структурам стали доставаться из регионов ресурсы, в первую очередь финансовые и человеческие. Малоэффективная пространственная структура страны привела за собой рост расходов на поддержку инфраструктур, которые избыточны на территориях, теряющих население и производственные активы. Новая система расселения и организация пространства направлены на транзитный характер развития большей части ее регионов и сырьевую специализацию. В основном данный процесс поддерживается зарубежными компаниями и институтами, которые заинтересованы в сырьевой специализации России. В такой ситуации фактически не ставятся цели регионального промышленного развития, характерные для эпохи индустриализации: физические масштабы производства, ВВП в стоимостном выражении, объем привлеченных капиталовложений. У глобального рынка есть единая, созданная на системе глобальных обменов «матрица капитализации», совмещающая все факторы, вовлечённые в рыночные процессы. Регионам, как и другим субъектам, необходимо стремиться к увеличению своего участия в этих обменах и повышению своей значимости (капитализации) в них. Стратегический застой продолжает заполняться действиями крупных корпораций. Большая часть регионов Российской Федерации сформировались как имеющие чёткую иерархию и централизацию, собранные вокруг корпораций, играющих основную роль, а следовательно, в своих планах и проектах развития теперь 
обречены следовать направлениями последних, что является основной причиной отсутствия конкурентоспособных региональных промышленных кластеров в России.

Роль и экономическое положение АЗРФ определяется природноресурсным потенциалом, не имеющим аналогов в других регионах страны, a также развитым производственным комплексом, транспортными коммуникациями и стратегически важным географическим положением. Большие запасы минерально-сырьевых, топливно-энергетических, лесных и биологических ресурсов обеспечивают конкурентоспособность продукции природно-ресурсных отраслей промышленности на внутреннем и внешнем рынках, несмотря на фактор, обусловленный суровыми природноклиматическими условиями: высокий уровень затрат на производство и воспроизводство трудовых ресурсов.

Заинтересованность России в Арктике определяется следующими причинами. Во-первых, экономические интересы. В настоящее время этот регион обеспечивает около $11 \%$ национального дохода России, здесь добывается значительное количество углеводородов и других полезных ископаемых, имеющих стратегическую важность для России, сохраняется промышленный потенциал. Также большие экономические перспективы имеют развитие и эксплуатация СМП - кратчайшей трассы между европейскими и дальневосточными морскими и речными портами. Во-вторых, Арктический регион имеет непосредственное отношение к обеспечению безопасности России. Здесь сосредоточен ряд важнейших предприятий оборонной промышленности. Государственная граница Российской Федерации на протяжении почти 20 тыс. км проходит по Северному Ледовитому океану.

Значительный интерес к Арктике заставил российское руководство осознать необходимость принятия основополагающих документов для определения арктической стратегии страны. Сегодня государственная политика России в Арктике определена и имеет серьезную легитимную основу, которая обозначена в ряде базовых документов. Основы государственной политики в АЗРФ отражены в Постановлении Правительства Российской Федерации от 21 апреля 2014 г. № 366 (ред. от 31 августа 2017 г. № 1064) «Об утверждении государственной программы Российской Федерации “Социально-экономическое развитие Арктической зоны Российской Федерации на период до 2020 года”» [52].

Важными факторами развития промышленного сектора АЗРФ являются рост инвестиционной активности и диверсификация производства, в основе которых повышение степени переработки (комплексности) сырья и ориентация на выпуск готовой продукции на внутренний рынок и экспорт.

Стратегическими приоритетами в развитии промышленных комплексов АЗРФ являются: решение комплекса конкретных задач по эффективности использования природного ресурсного потенциала на основе воспроизводства и совершенствования научно-технического потенциала; проведение структурной политики, ускорение реструктуризации производства и институциональных преобразований; активизация инвестирования в наиболее рентабельные и эффективные проекты и сферы 
деятельности; интенсификация развития промышленного сектора за счет повышения качества человеческого капитала.

Эти позиции обуславливают задачи по стабилизации и экономическому развитию Арктики. При разработке долгосрочной стратегии промышленного развития Арктики необходимо изучить важнейшие факторы и условия, сочетание которых оказывает и будет оказывать определяющее влияние на ход решения экономических и социальных задач регионов России в целом. Такими факторами являются, как уже неоднократно отмечалось и для всей зоны Арктики России, геополитическое и стратегическое положение, природно-климатический комплекс, производственно-технологическая система, трудовые ресурсы, финансово-бюджетная обеспеченность.

Проведенное исследование организации управления развитием промышленного сектора АЗРФ позволяет утверждать, что существующее государственное регулирование имеет ряд недостатков.

1. Почти полное отсутствие государственных мер регулирования регионального промышленного развития. Не все рассматриваемые регионы имеют закон о промышленной политики или концепцию промышленной политики (например, Мурманская область, республики Карелия и Коми), или такой закон морально устарел (Архангельская область - принят в октябре 2013 г.).

2. Концентрация финансовых ресурсов на федеральном уровне не заинтересовывает региональные органы государственной власти в повышении эффективности управления.

3. Отсутствует единая система стратегического планирования промышленного развития Российской Федерации, а также набор согласованных действий по упорядочиванию концепций развития регионов и отраслей промышленности.

4. Набор инструментов управления региональным промышленным развитием ограничен, сводится в основном к бюджетным трансфертам для обеспечения социальной стабильности через поддержку действующих, но не всегда конкурентоспособных предприятий, что противоречит идеи инновационной промышленной политики.

Специфика АЗРФ предполагает, что государственное регулирование промышленного развития должно осуществляться как на основе общих для всех регионов принципах, так и с помощью специальных механизмов, учитывающих макрорегиональные особенности. Хотя этот подход и используется в настоящее время, в реальной политике в отношении северных территорий существуют серьезные проблемы, что связано прежде всего с тем, что стратегический подход к формированию промышленной политики слабо проработан.

Политика в отношении развития промышленного сектора направлена в основном на решение узких проблем с помощью финансирования текущих расходов. Примерная схема формирования государственной промышленной политики АЗРФ с учетом стратегических приоритетов развития представлена на рис. 33. 


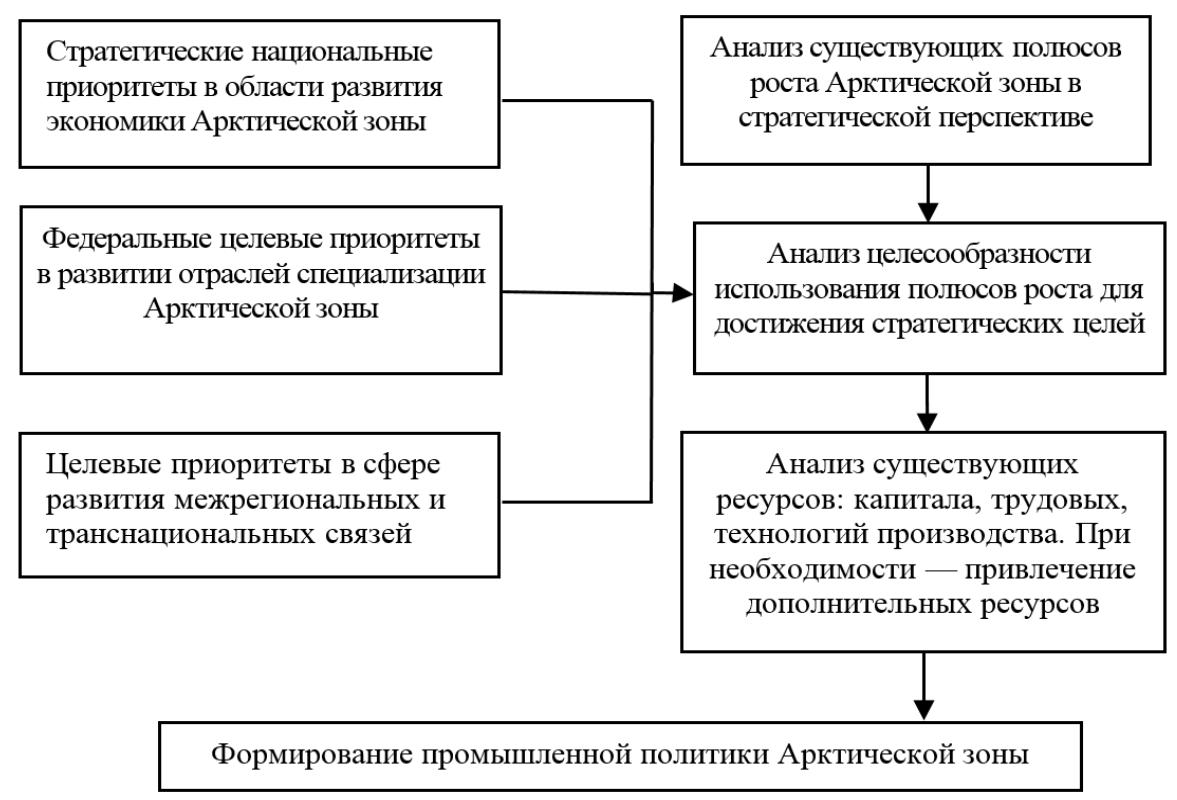

Рис. 33. Схема формирования промышленной политики АЗРФ с учетом стратегических приоритетов развития

Таким образом, стратегический приоритет промышленной политики на макроуровне - это объект политики, экономическое положение макрорегиона, его мирохозяйственные связи, сценарии промышленного развития, которые могут быть адаптированы к факторам внешней среды в соответствии с воздействием на него субъекта управления и имеют первоочередное значение для достижения стратегических целей на определенном временном интервале.

Определим промышленный аспект экономического пространства макрорегиона как систему взаимоотношений между промышленными предприятиями, властными структурами и местным сообществом на обособленной территории, в рамках которой участники реализуют правомочия собственности на факторы и результаты производства, что, в свою очередь, обеспечивает реализацию их интересов (рис. 33) [29].

Промышленное развитие экономического пространства макрорегиона формируется под действием факторов внешнего и внутреннего характеров. Так, с одной стороны, оно существует и трансформируется в рамках действия основных тенденций глобального развития, а с другой - адаптируется к региональной и российской специфике, характеризуемой пространственной неравномерностью распределения элементов производительных сил и необходимостью решения многочисленных проблем промышленного развития.

Поэтому при решении задач модернизации промышленного развития экономики макрорегиона мало довольствоваться только адаптацией к изменяющимся в силу тех или иных причин разнообразным факторам пространственного развития макрорегиона, но также надо иметь стратегию промышленного развития регионального пространства, предполагающую 
активное взаимодействие его с пространствами других регионов, страны и глобальным пространством.

Для этого необходимо в первую очередь определиться c перспективными целями промышленного развития экономического пространства на макроуровне.

Следует отметить, что настоящая активность государственных и региональных структур как потенциально ведущих субъектов целеполагания в сфере промышленного развития экономического пространства, на наш взгляд, недостаточна. В результате формирование экономического пространства макрорегиона идет по интегрированной (централизованной) модели и является результатом усилий крупных промышленных предприятий стратегически значимых отраслей, хозяйственные интересы которых объективно состоят в повышении внутрихозяйственной эффективности. Это приводит к торможению формирования бизнес-климата и инвестиционной среды, соответствующих требованиям рыночной экономики. Например, сегодня такие значимые для отечественной экономики промышленные корпорации, занимающиеся добычей и первичной переработкой сырья («Газпром», «Норильский никель», «Роснефть», «Северсталь» и т. п.), выступают как звенья транснациональных технологических цепочек, деятельность которых направляется из-за рубежа. Фактически именно в интересах зарубежных партнеров осуществляется строительство транспортных коридоров, ориентированных на экспорт сырья, экспортно-ориентированных портов, происходит доминирование сырьевых технологий в ущерб созданию отечественных предприятий по глубокой переработке сырьевых ресурсов на территории субъекта Российской Федерации, осуществляется развитие производственной инфраструктуры. При этом проблемы комплексного промышленного развития экономики российских регионов остаются нерешенными.

В результате деятельности таких корпораций происходят неблагоприятные сдвиги в промышленном развитии экономического пространства региона, а субъекты Федерации и государство несут существенные потери, связанные, в частности, с недополучением потенциальной добавленной стоимости, создаваемой в рамках таких технологических цепочек, усиливают свою зависимость от состояния рынка углеводородов и т. п. [57].

В этой ситуации представляется очевидным, что переломить такие негативные тенденции можно только при существенном увеличении роли региона при формировании целей перспективного развития его экономического пространства на основе сетевой модели, которая предполагает взаимодействие его участников на основе гибкой специализации.

Кроме того, в процессе целеполагания в сфере промышленного развития экономического пространства макрорегиона не должны быть забыты интересы его субъектов - властных структур (на федеральном, региональном и местном уровнях) и объекта - промышленных предприятий. Для этого необходимо уточнить методологию определения целей стратегического промышленного развития применительно к специфике такого объекта, как экономическое пространство макрорегиона, разработать 
на этой основе комплексную стратегию его перспективных преобразований, не ограничиваясь реализацией отдельных проектов федерального и регионального уровней.

При этом методологически важно рассмотреть понятие цели во взаимосвязи с понятиями «деятельность», «потребность» и «интерес». Целенаправленность как вид осознанной деятельности всегда отражает вполне конкретные потребности и интересы субъектов промышленного развития и регулирования регионального экономического пространства. Из этого следуют, во-первых, первичность потребностей по отношению к интересам; во-вторых, необходимость глубокого изучения потребностей и интересов субъектов развития и регулирования, участвующих в процессах стратегического развития промышленного пространства региона.

Закономерный характер промышленного развития экономического пространства макрорегиона не означает его априорной предопределенности, ибо могут складываться различные сценарные условия и, собственно, сценарии трансформации пространства, разрабатываться соответствующие им вариантные прогнозы целей развития и построения механизма их реализации, причем управленческие решения в рассматриваемой сфере зависят от сознательной деятельности людей. Поэтому цели промышленного развития и регулирования экономического пространства макрорегиона можно характеризовать как разработанную с использованием научных методов и объективных закономерностей промышленного развития модель его будущего состояния, определенную качественно с помощью целевой установки, количественно и во времени.

Процесс определения целей промышленного развития экономического пространства макрорегиона на долгосрочную перспективу схож с описанным процессом постановки целей промышленного развития макрорегиона. Главная цель промышленного развития экономического пространства макрорегиона состоит в повышении эффективности и конкурентоспособности промышленного сектора региональной экономики как базы повышения качества жизни его населения. Все остальные возможные цели представляются вторичными, производными от главной цели.

При разработке целей структурных преобразований промышленного пространства на макроуровне может быть использован следующий методологический подход. На основе анализа состояния потенциала макрорегиона определяются сложившиеся и прогнозируемые диспропорции его промышленного развития, что может послужить основой для выявления и содержательной трактовки совокупности соответствующих проблем, ранжирования их по значимости с народнохозяйственных позиций. Тогда цели структурных преобразований могут быть определены из рассмотрения результатов количественных оценок наиболее приоритетных проблем.

В этих условиях потенциал региона является основным фактором определения целей промышленного развития пространства макрорегиона (рис. 34).

Под стратегическим потенциалом макрорегиона будем понимать потенциал хозяйственной системы, состоящей из подсистем (участников) и взаимоотношений между ними, при этом его содержание следует уточнить. 


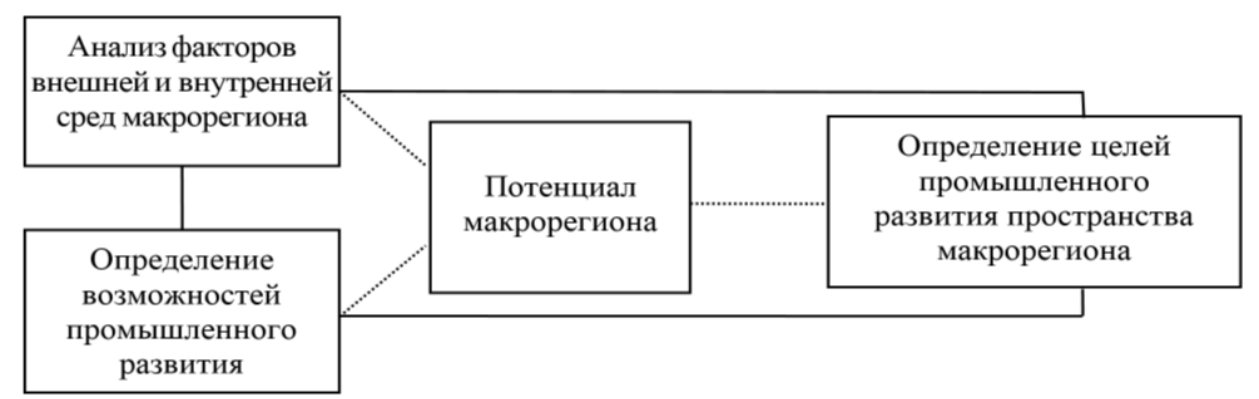

Рис. 34. Процесс определения целей промышленного развития пространства макрорегиона

Мы согласны с представлением потенциала промышленного развития макрорегиона как сложной системы, которую следует рассматривать c позиции структурного, административного, функционального, содержательного и продуктового подходов [17].

С позиции структурного подхода потенциал представляет собой систему, состоящую из ядра и оболочек, в рамках которых реализуется влияние факторов внешней среды, представленных различными подсистемами: оболочка первого вида в пределах региона и оболочка второго вида вне пределов региона.

Ядром потенциала является ресурсно-компетентностный потенциал хозяйствующих субъектов, входящих в регион, рассматриваемый нами как совокупность ресурсного и компетентностного потенциалов, и способы их активизации для достижения устойчивых конкурентных преимуществ на мезо- и макроуровнях.

Ресурсный потенциал - совокупность кадровых, материальных и нематериальных, информационных и финансовых ресурсов, необходимых для достижения целей промышленного развития региона.

Компетентностный потенциал - потенциал группы ресурсов в осуществлении функциональной деятельности (инновационной, инвестиционной, организационной, производственной и др.), необходимый для формирования устойчивых конкурентных преимуществ.

Оболочку первого вида - факторы внешней среды, влияющие на состояние и развитие потенциала хозяйствующих субъектов внутри макрорегиона, предлагается рассматривать как структуру промышленности макрорегиона, инфраструктуру макрорегиона и систему взаимоотношений между субъектами.

В качестве оболочки второго вида предлагается рассматривать следующие факторы влияния внешней среды: фактор ресурсного обеспечения функционирования и развития промышленности макрорегиона; фактор изменения спроса и предложения, влияние факторов макроокружения, в том числе и экономическую политику.

Кроме того, потенциал макрорегиона можно рассматривать с позиции: 1) административного подхода: совокупность потенциалов административных районов и округов, расположенных на территории макрорегиона; 2) содержательного подхода - как совокупность локальных 
потенциалов хозяйствующих субъектов, функционирующих на его территории; 3) функционального подхода - как совокупность локальных функциональных потенциалов (геополитического, экономического, инновационного, финансового, инвестиционного, рыночного и др.); 4) продуктового подхода - как совокупность локальных потенциалов видов деятельности, осуществляемых на территории, занимаемой макрорегионом.

Состав элементов стратегического потенциала макрорегиона с точки зрения перечисленных подходов приведен в табл. 14.

Таблица 14

Состав элементов стратегического потенциала макрорегиона

\begin{tabular}{|c|c|}
\hline Состав & Примечание \\
\hline \multicolumn{2}{|c|}{ Структурный подход } \\
\hline Ядро & Потенциалы отдельных субъектов \\
\hline Факторы первого круга & $\begin{array}{l}\text { Потенциал взаимодействия субъектов } \\
\text { внутри региона }\end{array}$ \\
\hline Факторы второго круга & $\begin{array}{l}\text { Потенциал взаимодействия региона } \\
\text { с внешней средой }\end{array}$ \\
\hline \multicolumn{2}{|c|}{ Административный подход } \\
\hline $\begin{array}{l}\text { Совокупность административных } \\
\text { районов и округов }\end{array}$ & $\begin{array}{l}\text { Различное значение и вклад в общий } \\
\text { потенциал }\end{array}$ \\
\hline \multicolumn{2}{|l|}{ Содержательный подход } \\
\hline Промышленный комплекс & \multirow{7}{*}{$\begin{array}{l}\text { Набор субъектов может быть } \\
\text { различным }\end{array}$} \\
\hline Транспортный комплекс & \\
\hline Научно-образовательный комплекс & \\
\hline Предприятия сферы услуг & \\
\hline Торговля & \\
\hline Социальная сфера & \\
\hline Другие & \\
\hline \multicolumn{2}{|c|}{ Функииональный подход } \\
\hline Геополитический & \multirow{6}{*}{$\begin{array}{l}\text { Каждый вид потенциала оценивается } \\
\text { по конкретной группе показателей }\end{array}$} \\
\hline Экономический & \\
\hline Инновационный & \\
\hline Инвестиционный & \\
\hline Финансовый & \\
\hline Рыночный & \\
\hline \multicolumn{2}{|c|}{ Продуктовый подход } \\
\hline $\begin{array}{l}\text { Потенциалы отдельных видов } \\
\text { деятельности региона }\end{array}$ & $\begin{array}{l}\text { Имеют различные значения и вклад } \\
\text { в общий потенциал }\end{array}$ \\
\hline
\end{tabular}

Далее рассмотрим проблему определения целей пространственной промышленной политики. Для этого уточним используемую терминологию.

Если пространственную промышленную политику на макроуровне рассматривать как систему намерений, реализующих интересы властных структур в отношении промышленного развития экономики макрорегиона, то цели пространственной промышленной политики на макроуровне должны 
отражать основные экономические интересы властных структур в сфере промышленного развития экономического пространства макрорегиона. Тогда общая методология определения целей пространственной промышленной политики макрорегиона в первом приближении представляется вполне очевидной: на основе выявления и гармонизации экономических интересов властных структур производится определение целевых установок в сфере регулирования промышленного развития экономического пространства макрорегиона, а затем и самих целей.

Однако, во-первых, властные структуры не однородны, их отдельные группы имеют различные экономические интересы; во-вторых, существуют влиятельные субъекты управления и хозяйствования, не входящие формально в состав властных структур, но имеющие свои интересы в развитии экономики страны. Интересы субъектов не всегда очевидны, поэтому возникает весьма сложная задача выяснения истинных, зачастую противоречивых, экономических интересов субъектов разработки и реализации пространственной промышленной политики макрорегиона.

Таким образом, можно видеть, что цели промышленного развития экономического пространства макрорегиона и государственной пространственной промышленной политики объективно имеют различную природу, отражают в целом противоречивые специфические экономические интересы хозяйствующих субъектов и структур регулирования промышленного развития макрорегиона и, следовательно, могут не совпадать.

Представляется целесообразным для устранения возможных противоречий целей промышленного развития экономического пространства макрорегиона и государственной пространственной промышленной политики осуществлять их гармонизацию. Причем гармонизируемые цели должны находиться в состоянии координации, а не подчинения одних другим [40].

Практическая реализация принципа гармонизации означает, в частности, необходимость разработки и введения в практику стратегического регулирования промышленного развития экономического пространства соответствующих координирующих процедур, использование которых должно быть регламентировано и осуществляться на регулярной основе.

Особенностью процесса разработки государственной промышленной политики на макроуровне является то, что она должна реализовываться в рамках существующей стратегии социально-экономического развития макрорегиона.

На этапе разработки промышленной политики на макроуровне необходимо определить исполнителей, состав и последовательность действий, сроки исполнения и необходимые конечные результаты, в качестве которых может быть разработка следующих документов: стратегии промышленного развития макрорегиона; целевых программ макрорегиона; бизнес-планов инвестиционных проектов.

В стратегию промышленного развития макрорегиона должны быть включены следующие разделы: сценарные условия перспективного промышленного развития макрорегиона; стратегический анализ и пути перспективного развития промышленного потенциала макрорегиона; 
основные цели, задачи и приоритеты промышленной политики макрорегиона на определенный временной интервал и механизмы реализации.

Механизм реализации является составной частью государственной промышленной политики. Его можно определить как совокупность средств, методов и ресурсов, определяющих алгоритм, последовательность и способ достижения цели. Сущность механизма реализации состоит в целенаправленном воздействии органов власти и управления разных уровней, руководства промышленных предприятий на субъекты политики.

Существует несколько подходов к определению состава механизма реализации промышленной политики в зависимости от поставленных в исследовании задач (табл. 15).

Таблица 15

Состав средств механизма реализации промышленной политики

\begin{tabular}{|l|l|}
\hline \multicolumn{1}{|c|}{ Автор } & \multicolumn{1}{|c|}{ Состав } \\
\hline А. Н. Нестеренко & $\begin{array}{l}\text { Прямые государственные инвестиции, кредитование } \\
\text { экспортных операций, капитальные вложения, } \\
\text { государственные гарантии по кредитам [43] }\end{array}$ \\
\hline Л. П. Пидоймо & $\begin{array}{l}\text { Льготное кредитование, льготное налогообложение, } \\
\text { экспортные премии, фонды страхования внешнеторговых } \\
\text { рисков }\end{array}$ \\
\hline А. И. Татаркин & $\begin{array}{l}\text { Проектный подход, кластерный подход, частно- } \\
\text { государственное партнерство, региональные институты } \\
\text { развития [63] }\end{array}$ \\
\hline В. А. Максимов, & $\begin{array}{l}\text { Разработка программы санации и перепрофилирования } \\
\text { предприятий в соответствии с критериями и приоритетами } \\
\text { принятой промышленной политики; осуществление } \\
\text { всесторонней экспертизы проектов и направлений развития, } \\
\text { претендующих на государственную поддержку; ускорение } \\
\text { перепрофилирования и модернизации предприятий, } \\
\text { существующих за счет государственной поддержки, } \\
\text { деятельность которых призана экономически } \\
\text { неэффективной и не отвечающей целям проводимой } \\
\text { промышленной политики [39] }\end{array}$ \\
\hline
\end{tabular}

По нашему мнению, структура механизма реализации промышленной политики должна включать: основные принципы реализации; нормативноправовую базу; организационные мероприятия; обеспечение и контроль процесса реализации; оценку эффективности проведения промышленной политики.

Основными принципами, на которых должен строиться механизм реализации промышленной политики на макроуровне, являются законность, обоснованность, гибкость, сбалансированность, безопасность и комплексность.

При разработке документов реализации необходимо обеспечить согласованность следующих документов: долгосрочных прогнозов 
и стратегических плановых документов развития промышленности; среднесрочных концепций и программ промышленного развития; отраслевых и территориальных целевых программ, планов действий администраций, бизнес-планов предприятий; целевых социальных программ, направленных на решение конкретных проблем структурной перестройки промышленности на макроуровне, в частности программы преобразования трудового потенциала макрорегиона, повышения его качества.

Обеспечение реализации промышленной политики макрорегиона должно включать нормативно-правовую, научно-методическую, финансовую, информационную, кадровую и другие составляющие.

Важнейшей составляющей механизма реализации является система контроля (обратной связи), которая должна иметь комплексный характер и включать в себя следующие формы: сбор и предоставление информации о ходе реализации политики; научно-практические конференции с участием субъектов политики; мониторинг хода реализации; оценку эффективности реализации политики.

Факторами, определяющими эффективность промышленной политики АЗРФ в современных условиях, когда макрорегион выступает не только как территориально обособленный субъект национальной экономики, но и как полноправный участник мирохозяйственных связей, становятся производство и передача знаний. Механизм реализации промышленной политики на макроуровне, учитывающий фактор знания, представлен на рис. 35.

Принципы политики обеспечивают общую структуру, в рамках которой ответственные за разработку стратегий обучения и инноваций на уровне макрорегиона должны действовать. Они отражают тот факт, что одновременный переход на новые формы экономической деятельности демонстрирует главные характеристики, которым должен соответствовать макрорегион. Следовательно, там, где реальная политика является продуктом взаимодействия между главными принципами политики и особенностями местной обстановки, процесс стратегического развития на уровне макрорегиона должен восприниматься как единое целое.

Не стоит преуменьшать важность политических процессов на уровне макрорегиона, что вовлекает решение сложных аналитических процессов, a также создание сложных политических механизмов, через которые стратегии могут быть разработаны и осуществлены. Стратегии требуют значительного количества времени, чаще всего измеряемого десятилетиями, а не годами, прежде чем их воздействие будет чувствоваться (в экономическом росте, изменении числа рабочих мест и тому подобном).

Таким образом, при разработке и реализации промышленной политики для Арктического макрорегиона необходимо выделение пространственного, структурного и инновационного аспектов промышленной политики, поскольку при принятии стратегических решений на макроуровне необходимо учитывать особенности территориального размещения промышленных объектов, структурных изменений в технологическом и управленческом аспектах промышленного развития, а также обеспечение необходимых трансформаций в промышленном развитии с точки зрения результативности научных исследований и разработок, системы подготовки кадров по приоритетам промышленного развития и территориям. 


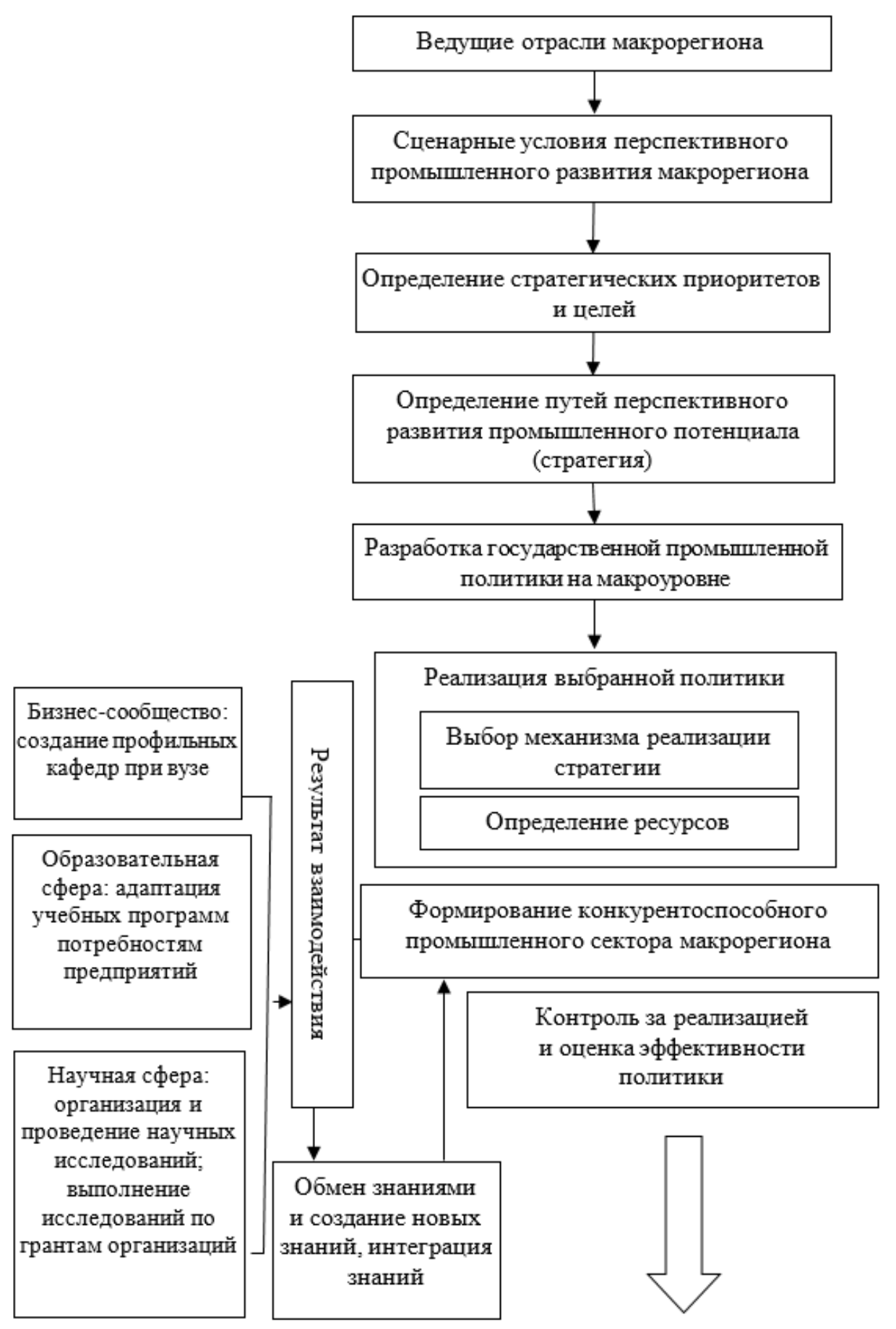

Рис. 35. Принципиальная схема механизма реализации промышленной политики на макроуровне с использованием инновационного фактора 


\section{3. Оценка экономической эффективности инвестиционного проекта в публичном акционерном обществе «Роснефть»}

Данный инвестиционный проект предполагает приобретение самоподъемной буровой установки (СПБУ) для работы по контракту с ОАО «Роснефть» в Арктике в течение 5 мес/год, остальное время СПБУ находится в отстое (экипаж в отстое - 15 человек).

Исходные данные для расчета представлены в табл. 16. Ставка работы по контракту составляет 215 тыс. долл/сут, курс доллара 74,59 руб/долл. (по курсу Центрального банка Российской Федерации за I квартал 2016 г.), стоимость СПБУ - 90 млн долл. США, расходы по СПБУ взяты по утвержденному бизнес-плану за 2014 г. предприятия.

В таблице 17 приведены расчеты дисконтированного денежного потока, на основании которых можно рассчитать чистую приведенную стоимость, индекс рентабельности, внутреннюю норму доходности и дисконтированный срок окупаемости, которые представлены в табл. 18.

Из приведенного расчета следует, что NPV проекта при горизонте планирования пять лет составляет 903,3 млн руб. при ставке дисконтирования $15 \%$ и 656,2 млн руб. при ставке дисконтирования $20 \%$.

Слабое место данного инвестиционного проекта в том, что большую часть года СПБУ находится в простое и, соответственно, не генерирует доходы. Как следствие, запас финансовой прочности у проекта находится на низком уровне.

Но на основании полученных расчетов можно сделать следующий вывод: NPV инвестиционного проекта является положительной величиной, IRR превышает $20 \%$, закрепление в качестве бурового подрядчика в Арктике и укрепление сотрудничества с ОАО «Роснефть» имеет положительные перспективы для акционерного общества «Арктикморнефтегазразведка».

Таблица 16

Исходные данные для расчета

\begin{tabular}{|l|r|}
\hline \multicolumn{1}{|c|}{ Показатель } & Значение \\
\hline \multicolumn{1}{|c|}{1} & 2 \\
\hline Ставка при работе по контракту, тыс. долл/сут & 215 \\
\hline Курс руб/долл. & 74,59 \\
\hline Время работы, сут/мес & 30,5 \\
\hline Работа (70 \% общего времени), сут/мес & 21,4 \\
\hline Простой (20 \% общего времени), сут/мес & 6,1 \\
\hline Ремонт (2 \% общего времени), сут/мес & 0,6 \\
\hline Простой по вине подрядчика (8\% общего времени), сут/мес & 2,4 \\
\hline Выручка, тыс. руб/мес & 447251 \\
\hline Работа, тыс. руб/мес (70 \% общего времени) - ставка 100 \% & 344039 \\
\hline Простой, тыс. руб/мес (20 \% общего времени) - ставка 95 \% & 93382 \\
\hline Ремонт, тыс. руб/мес (2 \% общего времени) - ставка 100 \% & 9830 \\
\hline
\end{tabular}


Окончание таблищь 16

\begin{tabular}{|l|r|}
\hline \multicolumn{1}{|c|}{1} & 2 \\
\hline $\begin{array}{l}\text { Простой по вине подрядчика, тыс. руб/мес (8 \% общего } \\
\text { времени) - ставка 0\% }\end{array}$ \\
\hline Расходы \\
\hline Стоимость приобретения СПБУ, тыс. руб. \\
\hline Расходы СПБУ в период работы, тыс. руб/мес & 6713100 \\
\hline Расходы на оплату труда, тыс. руб/мес & 43375 \\
\hline Страхование, тыс. руб/мес & 14084 \\
\hline Материалы, тыс. руб/мес & 12511 \\
\hline Топливо, тыс. руб/мес & 6804 \\
\hline Ремонт, тыс. руб/мес & 368 \\
\hline Транспортные расходы, тыс. руб/мес & 1712 \\
\hline Связь, тыс. руб/мес & 3658 \\
\hline Аренда оборудования, тыс. руб/мес & 355 \\
\hline Питание, тыс. руб/мес & 2539 \\
\hline Прочие расходы, тыс. руб/мес & 924 \\
\hline Расходы СПБУ в период простоя, тыс. руб/мес & 421 \\
\hline Расходы на оплату труда, тыс. руб/мес & 25143 \\
\hline Страхование, тыс. руб/мес & 5299 \\
\hline Материалы, тыс. руб/мес & 12511 \\
\hline Топливо, тыс. руб/мес & 3386 \\
\hline Ремонт, тыс. руб/мес & 184 \\
\hline Транспортные расходы, тыс. руб/мес & 1712 \\
\hline Аренда оборудования, тыс. руб/мес & 1055 \\
\hline Питание, тыс. руб/мес & 0 \\
\hline Прочие расходы, тыс. руб/мес & 267 \\
\hline $\begin{array}{l}\text { Стоимость ремонта при проведении промежуточного } \\
\text { освидетельствования в 2019 г., тыс. руб. }\end{array}$ & 375 \\
\hline
\end{tabular}

Таблица 17

Расчет дисконтированного денежного потока

\begin{tabular}{|c|c|c|c|c|c|}
\hline \multirow{2}{*}{ Показатель } & 0 & 1 & 2 & 3 & 4 \\
\hline & 2017 & 2018 & 2019 & 2020 & 2021 \\
\hline 1 & 2 & 3 & 4 & 5 & 6 \\
\hline Доходы СПБУ, тң & 2236255 & 2236255 & 2236255 & 2236255 & 2236255 \\
\hline Расходы СПБУ, т & -267162 & -392879 & -506031 & -392879 & -392879 \\
\hline $\begin{array}{l}\text { Расходы на оплату труда, } \\
\text { тыс. руб. }\end{array}$ & -81018 & -107515 & -107515 & -107515 & -107515 \\
\hline Страхование, тыс. руб. & -87574 & -150127 & -150127 & -150127 & -150127 \\
\hline Материалы, тыс. руб. & -40790 & -57719 & -57719 & -57719 & -57719 \\
\hline Топливо, тыс. руб. & -2205 & -3124 & -3124 & -3124 & -3124 \\
\hline Ремонт, тыс. руб. & -11984 & -20544 & -133696 & -20544 & -20544 \\
\hline
\end{tabular}


Окончание таблиць 17

\begin{tabular}{|c|c|c|c|c|c|}
\hline 1 & 2 & 3 & 4 & 5 & 6 \\
\hline $\begin{array}{l}\text { Транспортные расходы, } \\
\text { тыс. руб. }\end{array}$ & -20400 & -25676 & -25676 & -25676 & -25676 \\
\hline Связь, тыс. руб. & -2484 & -4258 & -4258 & -4258 & -4258 \\
\hline $\begin{array}{l}\text { Аренда оборудования, } \\
\text { тыс. руб. }\end{array}$ & -12697 & -12697 & -12697 & -12697 & -12697 \\
\hline Питание, тыс. руб. & -5156 & -6489 & -6489 & -6489 & -6489 \\
\hline Прочие расходы, тыс. руб. & -2855 & -4731 & -4731 & -4731 & -4731 \\
\hline $\begin{array}{l}\text { Денежный поток по } \\
\text { операционной деятельности, } \\
\text { тыс. руб. }\end{array}$ & 1969093 & 1843376 & 1730224 & 1843376 & 1843376 \\
\hline $\begin{array}{l}\text { Приобретение СПБУ, тыс. } \\
\text { руб. }\end{array}$ & -2875445 & -1723029 & -1723029 & -861515 & \\
\hline $\begin{array}{l}\text { Денежный поток по } \\
\text { инвестиционной } \\
\text { деятельности, тыс. руб. }\end{array}$ & -2875445 & -1723029 & -1723029 & -861515 & \\
\hline $\begin{array}{l}\text { Общий денежный поток, тыс. } \\
\text { руб. }\end{array}$ & -906351 & 120347 & 7195 & 981861 & 1843376 \\
\hline $\begin{array}{l}\text { Денежный поток нарастающим } \\
\text { итогом, тыс. руб. }\end{array}$ & -906351 & -786005 & -778810 & 203052 & 2046428 \\
\hline \multicolumn{6}{|l|}{$\begin{array}{l}\text { Дисконтированный } \\
\text { денежный поток, тыс. руб. }\end{array}$} \\
\hline $15 \%$ & -906351 & 104649 & 5440 & 645590 & 105395 \\
\hline $20 \%$ & -906351 & 100289 & 4997 & 568207 & 88897 \\
\hline \multicolumn{6}{|l|}{$\begin{array}{l}\text { Дисконтированный денежный } \\
\text { поток нарастающим итогом, } \\
\text { тыс. руб. }\end{array}$} \\
\hline $15 \%$ & -906351 & -801702 & -796262 & -150672 & 903284 \\
\hline $20 \%$ & -906351 & -806062 & -801066 & -232859 & 656115 \\
\hline \multicolumn{6}{|l|}{$\begin{array}{l}\text { Срок окупаемости } \\
\text { дисконтированный }\end{array}$} \\
\hline ставка дисконтирования $15 \%$ & 1 & 1 & 1 & 1 & 0 \\
\hline ставка дисконтирования $20 \%$ & 1 & 1 & 1 & 1 & 0 \\
\hline
\end{tabular}

Таблица 18

Расчет экономического эффекта

\begin{tabular}{|l|r|}
\hline \multicolumn{1}{|c|}{ Показатель } & \multicolumn{1}{|c|}{ Значение } \\
\hline NPV, тыс. руб. & 903284 \\
\hline ставка дисконтирования 15\% & 656115 \\
\hline ставка дисконтирования 20 \% & 41 \\
\hline IRR, \% & 1,13 \\
\hline PI & 1,09 \\
\hline ставка дисконтирования 15\% & 4 \\
\hline ставка дисконтирования 20\% & 4 \\
\hline DPP, лет & \\
\hline ставка дисконтирования 15\% & \\
\hline ставка дисконтирования 20\% & \\
\hline
\end{tabular}




\section{4. Организация предприятия по переработке смазочных материалов}

Российский рынок смазочных материалов является крупнейшим в Европе и одним из самых больших в мире. В настоящий момент на нем происходят структурные изменения, связанные с переходом от производства стандартных смазочных материалов в соответствии с ГОСТом к производству премиальной продукции. Помимо изменений технологического характера, на рынок оказывают влияние и макроэкономические условия, которые привели к росту спроса на отечественные материалы за счет сокращения потребления импорта. Основные игроки, представленные крупными нефтегазовыми компаниями, наращивают производственные мощности и повышают конкурентоспособность в премиальном сегменте. Тем не менее в некоторых секторах промышленности используется импортное оборудование, поэтому доля иностранных смазочных материалов в объеме потребления остается высокой [45].

\section{Потребление смазочных материалов}

Размер использования смазочных материалов в Российской Федерации, в том числе базовых масел, в 2015 г. составил 3,2 млн т, это на $13 \%$ больше, чем в 2011 г. (2,8 млн т). В этот же момент спрос, по сути, уменьшился на $6 \%$ - с 1,6 до 1,5 млн т.

Потребление смазочных материалов зависит от ряда финансовых и технических условий из-за его взаимосвязи с проциклическим характером рынка, поэтому существующий финансовый кризис, ряд ограничений со стороны западных стран, инфляция российского рубля и уменьшение потребительской активности со значительной вероятностью будут оказывать на него негативное влияние. Тем не менее в ближайшее время предполагается увеличение объема продаж легковых автомобилей, что может благоприятно сказаться и на потреблении смазочных материалов. Предполагается, что вследствие этого российский рынок автомобильных смазочных материалов восстановится и к 2023 г. вырастет на $12 \%$.

Кроме экономических причин падения спроса на смазочные материалы, существуют и технологические факторы: разработка более сложного оборудования и транспортных средств, которые потребляют меньший объем смазочных масел, также негативно влияет на спрос.

Существенное влияние динамики промышленного производства связано с высокой долей промышленных масел в общем спросе. В России 53 \% от всех потребляемых смазочных материалов приходится на моторные масла, а 47 \% - на различные виды смазочных масел, применяемых в промышленном производстве, более трети из которых (37 \%) предназначены для гидравлических систем. Общий объем потребления пластичных смазок в России составил 140 тыс. т в 2015 г. [38].

\section{Производство смазочных материалов}

В 2015 г. в Российской Федерации было изготовлено 4,2 млн т смазочных материалов, что на $20 \%$ больше, чем в 2011 г. (около 1 млн т). Главным условием роста стало повышение количества производимых смазочных масел, в тот же момент изготовление пластичных смазок 
и суспензий для нанесения твердых смазочных покрытий за аналогичный промежуток времени значительно сократилось (на $53 \%$ - с 13,8 до 6,5 тыс. т), что связано с изменением структуры потребления. Отечественные производители в основном изготавливают определенные пластичные смазки в соответствии с ГОСТом. Понижение потребительского спроса приводит к уменьшению количества производимых продуктов.

Выпускаемые смазочные материалы включают в себя главным образом смазочные масла, на которые приходится 93 \% от общего объема. В частности, индустриальные и моторные масла составляют 18 и $17 \%$ соответственно в объеме производства смазочных материалов в России [30].

Рынок смазочных материалов является вполне перспективным. Промышленный сектор использует около 700 тыс. т смазочных материалов в год. Крупнейшими потребителями являются горнодобывающая, нефтеперерабатывающая, энергетическая, металлургическая и автомобильная отрасли, на которые приходится 79 \% от общего объема промышленного потребления.

Согласно данным, нефтегазовая (сегменты разведки, добычи и транспортировки) и сталелитейная отрасли потребляют наибольшие объемы смазочных материалов (в совокупности 147 тыс. т) [30].

В результате обесценения российского рубля наблюдается рост объемов импортозамещения. В наибольшей степени это относится к машиностроительной и энергетической отраслям. В металлургии $97 \%$ потребления смазочных масел осуществляется за счет внутреннего производства.

Помимо наращивания мощностей, более интенсивного использования оборудования и соответствующего роста объемов производства, также существует технологический фактор, влияющий на будущие объемы потребления смазочных материалов. В настоящий момент промышленный сектор характеризуется высокой степенью износа оборудования. Его модернизация и применение энергосберегающих технологий являются ключевыми приоритетами, хотя ограниченный доступ к капиталу и обесценивание российского рубля ставят под вопрос инвестиционные планы российских производителей. Кроме модернизации, наблюдается тенденция к импортозамещению оборудования, что обусловлено как государственной программой, так и девальвацией рубля.

В 2015 г. российское правительство изменило налоговое законодательство в сфере нефти и газа, чтобы простимулировать модернизацию нефтеперерабатывающих заводов и увеличить глубину переработки нефти, что также сказывается на рынке товарных смазочных материалов [9]. Цель изменений - постепенное повышение налогов на горную добычу в 1,7 раза и снижение таможенных пошлин на нефть в 1,7 раза, а на светлые нефтепродукты - в 1,7-5 раз. Кроме того, акцизы должны были снизиться в 2,2 раза, а таможенные пошлины на темные нефтепродукты достигнуть 100 \% таможенных пошлин на нефть к 2017 г.

Снижение пошлины позволяет увеличить маржинальность производства базовых масел в России. Это создает дополнительные возможности для модернизации, а также выгодно для промышленности даже 
при низких ценах на нефть. Естественно, у каждой компании свои обстоятельства, и основным вопросом здесь будет спрос.

В конце 2016 г. было решено заморозить налоги на год и удержать экспортные пошлины на уровне 2015 г. [21].

Есть ключевые независимые факторы, которые значительно влияют на мировой и российский сегменты базовых масел и смазочных материалов: 1) потребители - движущая сила изменений, им нужна более высокая эффективность, удобство, низкий уровень шума, более длительные интервалы между заменой масла, а также продукция с улучшенными потребительскими качествами, что позволит снизить операционные расходы (особенно увеличение эффективности топлива); 2) окружающая среда глобальные усилия по снижению вредных выбросов, в частности $\mathrm{CO}_{2}$, приводят к новым законодательным требованиям и государственным инициативам, направленным на изменение характеристик производимого оборудования, которые должны соответствовать новым экологическим стандартам и допускать использование альтернативных видов топлива; 3) оборудование - его производители, пытаясь получить конкурентное преимущество, разрабатывают новые технологические решения для удовлетворения потребителей; 4) глобализация - все это происходит на фоне глобализации, которая еще сильнее осложняет ситуацию с базовыми маслами и смазочными материалами и влияет на экономику бизнеса.

Итак, спрос на базовые масла в России обусловлен спросом на товарные смазочные материалы. На данный момент по причинам изменения экономической ситуации спрос в сегменте автотранспорта двигается в сторону отечественных смазочных материалов. Одним из ключевых моментов для компаний-производителей становится повышение их качества как конкурентное преимущество. Состав топлив и смазочных материалов при их использовании в промышленном производстве и при эксплуатации следует корректировать. При изготовлении корректировка топлив и смазочных масел выполняется с поддержкой инновационных технических процессов и прибавлением особенных присадок на стадии получения товарных продуктов. В современных условиях применения топлива и смазочных материалов для минимизации неблагоприятных изменений и с целью восстановления качества продуктов используются физические (фильтрование, сепарирование и т. д.) и химические методы (гидрогенизация, применение реагентов) [50].

При производстве, транспортировке, хранении и использовании топлив и смазочных материалов протекают следующие процессы, значительно меняющие качество продуктов: физические - загрязнение механическими примесями, испарение легких фракций, кристаллизация, поглощение влаги, смешение с другими нефтепродуктами и др.; химические полимеризация, окисление углеводородов и гетероатомных соединений, коррозия металлов и др.; физико-химические - сольватация, коагуляция механических примесей и продуктов окисления, адсорбция и десорбция на металлических поверхностях узлов трения и др.

При транспортировке, хранении и применении изменяется состав и ухудшаются свойства товарных топлив и масел. Для удаления из них 
механических примесей и воды используются такие физические процессы, как отстаивание, декантация, центрифугирование, фильтрование [50].

Современные условия эксплуатации техники и систем требуют от производителей смазочных материалов, с одной стороны, обеспечения надежности работы механизмов за счет использования и подбора специальных продуктов, с другой стороны, снижения эксплуатационных издержек для производств. Усиливают эти тенденции финансовые ограничения, налагаемые на предприятия.

В таких условиях специалисты по техническому обслуживанию машин и оборудования должны принимать решения с учетом принципа экономической целесообразности использования тех смазочных материалов, которые максимально увеличат жизненный цикл самого продукта и обеспечат пригодность оборудования и заданные эксплуатационные характеристики.

Очевидно, необходим мониторинг состояния масел, который предполагает набор методов испытаний, отражающих информацию о механическом состоянии смазочной системы. Потенциальными преимуществами использования эффективной программы мониторинга являются уменьшение технического обслуживания, снижение стоимости, увеличение срока службы системы и эксплуатационной пригодности, повышение безопасности.

Система мониторинга должна предоставлять пользователю практически бесценную информацию. Интерпретация результатов имеет решающее значение, а понимание данных о состоянии системы является фундаментальным для любой программы мониторинга рабочего состояния оборудования.

Пользователю нецелесообразно доверять программе мониторинга, выдающей огромное количество результатов испытаний, но при этом неспособной предоставить конкретную информацию о состоянии контролируемых систем.

Мониторинг состояния масла (ОСМ - отслеживание состояния масла) можно использовать для контроля рабочего состояния жидкости и оборудования во многих отраслях промышленности: нефтяных компанияхгигантах / поставщиках; шельфовой добыче (буровые платформы); судостроении и судоходстве (двигатели, редукторы и т. д.); горнодобывающей (транспортные средства и горно-шахтное оборудование); военной (Военной-морской флот, сухопутные войска и Военно-воздушные силы); аэрокосмической (авиакомпании и обслуживающие системы) промышленности; энергетике / автомобилестроении (ветровые турбины, электростанции / парк транспортных средств).

Преимущества использования системы мониторинга - в повышенной надежности и операционной эффективности при выявлении приближающегося отказа компонента системы на ранней стадии, снижении эксплуатационных расходов благодаря заблаговременному планированию технического обслуживания оборудования до того, как чрезмерный износ станет причиной вторичных повреждений, более длительном интервале между текущим и капитальным ремонтами в связи с полной уверенностью в раннем выявлении дефектов, снижении эксплуатационных расходов. 
Риски в случае отсутствия программы мониторинга - более высокие эксплуатационные расходы, увеличение времени простоя и количества отказов.

О проблеме загрязнения окружающей среды опасными отходами производства регулярно дискутирует мировое экологическое сообщество. На данной стадии формирования и совершенствования техногенной культуры, связанной с регулярной добычей и применением природных углеводородов в различных сферах производства, самое негативное воздействие на природную среду оказывают переработанные нефтепродукты. Главным направлением для большинства стран мира определяется сохранение природных ресурсов, стратегически значимых для человечества в целом (нефти и газа), запасы которых не восстановимы.

Все эти факторы влияют на актуальность и обязательность утилизации переработанных нефтяных продуктов. Проблема промышленных отходов требует безотлагательного решения, которое предполагает внедрение современных технологий, обмен опытом между странами, знаниями законодательства в области обращения с отходами, повсеместную переработку вторичных ресурсов [12].

Многие страны мира приняли законы, которые запрещают сброс вредных веществ в окружающую среду или обязывают осуществлять их сбор для дальнейшей переработки.

В Российской Федерации в соответствии с Основами государственной политики в области экологического развития России на период до 2030 года утвержден решением Совета Евразийской экономической комиссии от 20 июля 2012 г. № 59 технический регламент Таможенного союза (ТР ТС 030/2012 «О требованиях к смазочным материалам, маслам и специальным жидкостям»), который обеспечивает единые требования к смазочным материалам [30].

Сейчас в Российской Федерации проводятся мероприятия по обеспечению ресурсосбережения. Около десяти лет функционирует проект «РОСА», который охватывает более пятнадцати регионов. Также существует слаженная система сбора отработанных нефтепродуктов от севера страны до юга, от центра до востока.

В ходе осуществления этого проекта эксперты производят сбор, вывоз, переработку отходов нефтяной промышленности и др. на специальном комплексе в Рязани. Отходы, которые не подлежат переработке, утилизируются (обводненные мазуты, неликвидные горюче-смазочные материалы, нефтешламы и некондиционные нефтепродукты, аккумуляторные батареи, использованные смазочные материалы, автопокрышки, загрязненный грунт и др.).

Все еще существует необходимость в централизованной системе сбора и утилизации отработанных масел, так как они тоннами попадают в почву, на свалки, сжигаются, нанося при этом большой вред окружающей среде. Сейчас поднимается вопрос о создании такой системы на территории России, что потребует согласованных действий со стороны многих организаций и государства.

Следует утвердить нормы сдачи на утилизацию отработанных нефтепродуктов, которые образуются в результате хозяйственной 
деятельности предприятий. Они должны соблюдаться в соответствии с лимитом на размещение отходов, который утвержден для данных лиц в соответствии с действующим законодательством, а в отношении субъектов малого и среднего предпринимательства — в соответствии с отчетностью об образовании и использовании отходов, предоставляемой в уведомительном порядке.

Вопросы выбора технологии по утилизации отработанных масел в различных странах проработаны и реализованы, но их цели не везде одинаковы. Цели вторичной переработки в Российской Федерации переработка отработанных машинных масел и других видов СМ, удаление примесей и присадок, производство базовых масел качества, близкого к первоначальному, восстановление таких характеристик, как вязкость, точка вспышки, цвет и пр. с целью достижения уровня качества базовых масел группы II.

Характеристики отработанного масла: 80 \% масла, 15 \% присадок и примесей, 5 \% воды. Масло не теряет смазывающих свойств, но загрязняется; восстановление первоначального качества масла происходит путем удаления примесей и остаточных химических присадок.

Типичные присадки - противоизносные (например, фосфаты); антизадирные (например, сульфиды и фосфаты); очищающие (например, сульфонаты и фосфонаты с содержанием кремния, кальция, магнезия); ингибиторы коррозии (фосфаты и ароматика).

Примеси - продукты сгорания, твердые частицы (дорожная пыль, метал), продукты окисления (окисление некоторых молекул масла в органические кислоты).

Процесс очистки включает: 1) предварительную подготовку дегидратацию и фильтрацию, дистилляцию (испарением, мембранную), удаляется большинство продуктов горения и твердых частиц; 2) конечные процессы - доочистку (бокситную систему либо гидроочистку), удаляются оставшиеся частицы, продукты окисления и присадки; 3) доочистку (гидроочистку) - из-за высокой цены подходит для крупных предприятий, возможны глубокие гидродесульфуризация и гидродеметаллизация.

Экспериментальная коагуляция. Каждая партия отработанного масла требует проверки и подбора реагентов. Хорошо коагулируют минеральные масла. Масло с примесью синтетики плохо поддается такой очистке (высокий процент осадка и длительный отстой) [14].

Простой отстой - медленный процесс, затратный по времени и оборудованию, может продолжаться от 5 до 30 дней, при этом необходима зачистка отстойников.

Сепарация в центрифуге - интенсивный и экономичный процесс, требующий тонкой настройки центрифуги, при этом выгрузка осадка непрерывна и механизирована.

Адсорбционная (контактная очистка) - осветление отстоя после коагуляции или пермеата после микрофильтрации. В результате образуется отход - отработанная промасленная глина, подлежащая утилизации или высокотемпературной регенерации. 


\section{ЗАКЛЮЧЕНИЕ}

Арктическая зона Российской Федерации имеет площадь около 9 млн км², здесь проживает более 2,5 млн человек, что составляет около $40 \%$ населения всей Арктики. АЗРФ обладает высоким социально-экономическим и природно-ресурсным потенциалом, что влияет на ключевые геополитические тенденции, которые необходимо учитывать при разработке стратегии развития территорий. Россия является одной из наиболее значимых стран, организующих экономическую, политическую и военную деятельность на территории Арктики.

Арктический регион стратегически важен для дальнейшего устойчивого развития Российской Федерации, что обусловлено рядом факторов. На территории Арктики локализованы запасы углеводородов (нефти и природного газа), формирующие значительную часть доходов бюджета страны. Проходящий по территории Арктического региона СМП является базовым инструментом регионального развития, обеспечивающим стабильное функционирование Севера России. Российская Арктика является северным рубежом страны, военное присутствие в котором выступает гарантом национальной безопасности и региональной стабильности.

Деятельность нефтегазовых корпораций в Арктике изменила социально-экономическую политику, которая ускорила темпы формирования и развития инфраструктурной поддержки нефтегазовой отрасли в Арктике. Содержание деятельности корпоративных предпринимательских структур предполагает переход от ведения текущей деятельности к предпринимательской, что продиктовано требованиями рынка и государственных органов.

Сервисная деятельность предпринимательских структур, как и любой другой способ ведения хозяйства, многообразен и имеет массу вариантов для реализации предпринимательских инноваций. Для рассматриваемой пары взаимодействующих структур холдинг - сервис наиболее сложным является взаимодействие по управленческим инновациям, тогда как технологические применяются в любых вариантах. Множество современных сервисных предпринимательских структур, реально использующих инновационный потенциал, когда-то были частью холдинговых предпринимательских структур. Зачастую эти предпринимательские структуры являются аффилированными в отношении последних, что предопределяет узкий круг потребителей высокотехнологичных, а во многом и инновационных услуг.

Основным источником конкурентных преимуществ отечественных предпринимательских структур является государственная поддержка. Однако далеко не все законодательные акты гарантируют современной предпринимательской структуре поступательное, эффективное развитие. Множество проблем у современных предпринимательских структур имеется в сфере защиты прав на инновации, так как патентное законодательство на территории Российской Федерации практически не действует.

В целом на сегодняшний день не наблюдается единой системы или концепции государственного регулирования и поддержки предпринимательства в нефтегазовом секторе. Во многом проблемы государственного регулирования 
деятельности предпринимательских структур на рынке нефтепродуктов усложняются отсутствием эффективных взаимосвязей между различными наблюдательными органами и органами власти.

За последнюю четверть века произошло значительное устаревание существующей транспортной инфраструктуры Арктики. Исторически главной транспортной артерией являлся СМП, который и сейчас используется для обеспечения АЗРФ: он связывает такие крупные центры, как Мурманск и Архангельск с малонаселенными территориями Якутии и Чукотки. Однако если в советское время по СМП перевозилось 12 млн т грузов за одну навигацию, то в 1990-е гг. эти цифры снизились до 1 млн и до настоящего времени не увеличились.

Из Арктики продолжается отток населения, в первую очередь квалифицированных специалистов. Так, только из Мурманской области за последние двадцать пять лет выехало около 340 тыс. человек. Для того чтобы остановить этот процесс, надо создавать комфортные условия для проживания и работы населения: строить современные жилые дома, детские сады, школы, больницы, спортивные сооружения, культурные комплексы, учреждения высшего и среднего образования. Для закрепления молодежи должны быть созданы условия для получения образования и квалификации, применимых к занятости в АЗРФ (геологоразведка, климатология, полярная авиация и др.). Строительство современных зданий университетов, становящихся опорными точками развития АЗРФ (Арктического плавучего университета, филиалов центральных вузов России), позволит решить эту задачу.

Объекты производственной, транспортной и социальной инфраструктуры невозможно создавать и эксплуатировать без надежного энергетического обеспечения и развитой инженерной инфраструктуры. Отдельные территории АЗРФ имеют различные показатели обеспеченности и стоимости энергоресурсов. Так, Мурманская область является энергоизбыточным регионом, который в полном объёме удовлетворяет внутренний спрос.

Функционирование добывающих мощностей (нефть, газ, медь, олово, редкоземельные металлы, золоторудное сырье) преимущественно связано с развитием производственной инфраструктуры АЗРФ, ключевым объектом которой является завод «Ямал СПГ». Его строительство предусматривало привлечение различных источников финансирования. Приоритетные проекты развития АЗРФ создают спрос на высокотехнологичные направления, в том числе на робототехнику, топливные технологии, материаловедение. В рамках этих проектов не предполагается создание таких мощностей на территории АЗРФ, однако арктический проект формирует заказ в научноисследовательской и инновационной сферах экономики страны.

Арктическая зона Российской Федерации стала областью возможного международного конфликта из-за начавшегося хозяйственного освоения ее территорий. Кроме политических и правовых действий, актуальным является капитальное строительство по восстановлению инфраструктуры аэродромов и портов двойного назначения (Амдерма, Диксон, Тикси), развитие наземных сооружений для космических систем и навигационного оборудования. 


\section{ЛИТЕРАТУРА}

1. Авдулов А. Н., Кулькин А. М. Проблемы регионального развития в контексте государственной и научно-технической политики: опыт США. М., 1999. 166 c.

2. Агарков С. А., Богачев В. Ф., Богоявленский И. В., Брызгалова А. Е. и др. Современные проблемы и перспективы развития арктического газопромышленного комплекса. Апатиты; Мурманск: КНЦ РАН, 2017. $228 \mathrm{c}$.

3. Асаул А. Н., Владимирский Е. А., Гордеев Д. А., Гужва Е. Г., Петров А. А., Фалинский Р. А. Закономерности и тенденции развития современного предпринимательства. СПб.: АНО «ИПЭВ», 2008. 280 с.

4. Афанасьев М. Новый метод оценки бизнес-идеи инвестиционного проекта // Инвестиции в России. 2002. № 12. С. 29-36.

5. Балалаев А. С., Леонтьев Р. Г. Методология формирования транспортных логистических цепей / М-во трансп. Российской Федерации; Федеральное агентство ж.-д. трансп.; ГОУ ВПО «Дальневосточный гос. ун-т путей сообщения». Хабаровск, 2009.

6. Балашов В. Г., Заложнев А. Ю., Новиков Д. А. Механизмы управления организационными проектами. М.: ИПУ РАН, 2003. 84 с.

7. Барашева Т. И., Башмакова Е. П., Биев А. А., Бритвина С. В. Мурманская область в XXI веке: тенденции, факторы и проблемы социальноэкономического развития. Апатиты: КНЦ РАН, 2009. 192 с.

8. Бард В. С. Инвестиционные проблемы российской экономики. М.: Экзамен, 2000. 384 с.

9. Башмакова Е. П., Селин В. С. Развитие экономического пространства Российской Арктики на основе модернизации нефтегазового комплекса // Вестник Кольского научного центра РАН. 2013. № 2 (13). С. 98-108.

10. Богатин Ю. В., Швандер В. А. Инвестиционный анализ. М.: ЮНИТИ ДАНА, 2000. $286 \mathrm{c.}$

11. Богачев В. Ф., Веретенников Н. П. Формирование организационноэкономического механизма регулирования потребления водных биологических ресурсов // Мир экономики и права. 2013. № 7-8. С. 4-11.

12. Богачев В. Ф., Веретенников Н. П., Евграфова Л. Е. Социальноэкономические аспекты устойчивого развития промышленного рыболовства в Арктике // Вестник Мурманского государственного технического университета. 2014. Т. 17, № 3. С. 431-436.

13. Борисов Е. А., Галичанин Е. Н., Уваров В. А., Штыров В. А. СевероВосток России: региональная экономика и управление: кол. монография / под редакцией Е. А. Борисова, В. А. Уварова; Дальневосточная акад. гос. службы. Хабаровск, 2005.

14. Бурцев О. В., Козьменко С. Ю., Шиян Г. Н. Современная Россия и морская цивилизация // Морской сборник. 2006. № 6. С. 17-21.

15. Веретенников Н. П., Богачев В. Ф., Ульченко М. В. Северный морской путь: транспорт, экономика, геополитика // Вестник МГТУ. 2015. Т. 18, № 3. С. 386-392. 
16. Веретенников Н. П., Геращенко Л. В., Горячевская Е. С. Северный морской путь: история, экономика, геополитика, безопасность // Геополитика и безопасность. Балтийский государственный технический университет «Военмех». 2015. № 2 (30). С. 88-95.

17. Ветрова Е. Н., Гладышева И. В. Особенности стратегического позиционирования региона в контексте освоения запасов углеводородов Арктики на примере Архангельской области // Известия вузов. Горный журнал. 2014. № 1 (33). С. 63-73.

18. Ветрова Е. Н., Рохчин В. Е. Разработка сценарных условий долгосрочного развития региона: анализ опыта и методологические предложения // Новая экономика России: наука и образование: тез. докл. всерос. науч.-практич. конф. (Санкт-Петербург, 9-10 июня 2014 г.) / редкол.: А. Е. Карлик (отв. ред.) и др. СПб.: Изд-во СПбГЭУ, 2014. Секции 3, 4, 5. С. 76-82.

19. Геращенко Л. В., Козьменко С. Ю., Ульченко М. В. Приоритеты экономического развития России в Арктике // Экономика и предпринимательство. 2013. № 12-3 (41). С. 41-45.

20. Главные качества топ-менеджера - профессионализм, компетентность и интеллект // SuperJob: сайт. URL: https://www.superjob.ru/community/ career/16127/.

21. Глобальные тенденции освоения энергетических ресурсов Российской Арктики. Ч. І. Тенденции экономического развития Российской Арктики / под науч. ред. д. э. н. С. А. Агаркова, чл.-корр. РАН В. И. Богоявленского, д. э. н. С. Ю. Козьменко, д. т. н. В. А. Маслобоева, к. э. н. М. В. Ульченко. Апатиты: КНЦ РАН, 2019. 170 с.

22. Гонтарь Ю. А. Асимметрия экономического развития регионов. Современные проблемы. Стратегия регулирования. Ставрополь, 2001. $2016 \mathrm{c}$.

23. Гранберг А. Г. Основы региональной экономики. М., 2000.

24. Дмитрий Зубарев. Санкции США лишили «Ямал СПГ» трети ледового флота, 01.10.2019 // Взгляд: деловая газета. URL: https://vz.ru/news/ 2019/10/1/1000579.html.

25. Доброхотов А. Л. Цель // Новая философская энциклопедия / Ин-т философии РАН; Нац. обществ.-науч. фонд; предс. науч.-ред. совета В. С. Стёпин, заместители предс.: А. А. Гусейнов, Г. Ю. Семигин, уч. секр. А. П. Огурцов. 2-е изд., испр. и допол. М.: Мысль, 2010.

26. Друкер П. Эффективное управление. Экономические задачи и оптимальное решение. М.: ФАИР-ПРЕСС, 1998. 284 с.

27. Дьячкова О. В., Герасимов Б. И. Экономический анализ региональной поляризации. Тамбов, 2003. $114 \mathrm{c}$.

28. Иванов Г. В. Национальная безопасность России в Арктике: проблемы и решения // Вестник МГТУ. 2015. Т. 18, № 3. С. 401-406.

29. Изменение конфигурации экономического пространства региона на основе реализации потенциала промышленных районов / Н. Г. Багаутдинова, И. Р. Гафуров // Российское предпринимательство. 2012. № 2 (200). C. $166-171$. 
30. Канделаки Т. Россия в эпоху перемен. Обзор российского рынка смазочных материалов и нынешних тенденций // Материалы конференции «Масла и топливо СНГ». 2016.

31. Козловская О. В. Методология исследования стратегии развития региона. Томск, 2005. $132 \mathrm{c}$.

32. Комков Н. И., Селин В. С., Цукерман В. А., Горячевская Е. С. Сценарный прогноз развития Северного морского пути // Проблемы прогнозирования. 2016. № 2. С. 87-98.

33. Крапивский Е. И., Миннегулова Г. С., Садыкова Р. М. Экономический анализ проекта «LHG-MIX PIPELINE TRANSPORTATION» (МАГИСТРАЛЬНЫЙ ТРУБОПРОВОДНЫЙ СЖИЖЕННОЙ ГАЗОВОЙ СМЕСИ) // Горный информационноаналитический бюллетень (научно-технический журнал). 2015. № 12. C. $333-341$.

34. Леонтьев Р. Г. Введение в аксиоматику транспортной логистики. Хабаровск, 2007. 57 с.

35. Леонтьев Р. Г., Веретенников Н. П. Континуум императивов государства, корпораций и регионального бизнеса. Владивосток, 2006. 419 с.

36. Леонтьев Р. Г., Орлов А. Л. Транзитный потенциал транспорта Дальнего Востока Российской Федерации (гипотезы и реалии). Хабаровск, 2011. $302 \mathrm{c}$.

37. Макконел К. Р., Брю С. Л. Экономикс. М.: Республика, 1992. Т. 1. 399 с.

38. Масла Лукойл. Издание ООО «ЛЛК-Интернешнл». № 20. Июль 2009.

39. Максимов В. А., Спиридонов М. А. Федеральный и региональный компоненты промышленно-инвестиционной политики // Экономический вестник Ростовского государственного университета. 2003. Т. 1, № 2. C. $106-116$.

40. Минакир П. А., Демьяненко А. Н. Региональное сценарное прогнозирование // Федерализм. 2012. № 1. С. 29-44.

41. Мировой рынок СПГ: иллюзия избытка // Vygon consulting. URL: https://vygon.consulting/upload/iblock/542/vygon_consulting_lng_world_bala nce_2018.pdf (дата обращения: 12.06.2020).

42. Молочников Н. Р., Пономарева Т. Г. Развитие многоуровневой конкурентоспособности. СПб.: Изд-во Политехнического ун-та, 2008. 97 с.

43. Нестеренко А. Н. Промышленная политика - инструмент перехода к экономическому росту // Экономика. М.: Проспект, 1998. 792 с.

44. Новиков Ю. В. Малое предпринимательство и концепция адаптивного управления малыми предприятиями. СПб.: Астерион, 2009. 64 с.

45. Обзор рынка смазочных материалов. М.: Эрнст энд Янг - оценка и консультационные услуги, 2015. 17 с.

46. Официальные периодические издания: Статистический обзор мировой энергетики 2018 года // British Petroleum. URL: https://www.bp.com/ content/dam/bp/ business-sites/en/global/corporate/pdfs/energy-economics/ statistical-review/bp-stats-review-2018-full-report.pdf (дата обращения: 10.06.2020).

47. Официальные периодические издания: Статистический обзор мировой энергетики 2019 года // British Petroleum. URL: https://www.bp.com/ content/dam/bp/business-sites/en/global/corporate/pdfs/energy-economics/ 
statistical-review/bp-stats-review-2019-natural-gas.pdf (дата обращения: 25.05.2020).

48. Официальные периодические издания: Статистический обзор мировой энергетики 2019 года // British Petroleum. URL: https://www.bp.com/ content/ dam/bp/business-sites/en/global/corporate/pdfs/energy-economics/ statistical-review/bp-stats-review-2019-full-report.pdf (дата обращения: 10.06.2020).

49. Официальные периодические издания: Статистический обзор мировой энергетики 2020 года // British Petroleum. URL: https://www.bp.com/content/dam /bp/business-sites/en/global/corporate/pdfs/ energy-economics/statistical-review/bp-stats-review-2020-full-report.pdf (дата обращения: 10.06.2020).

50. Петко О. В., Журавлева А. О. Производство и рынок смазочных материалов, возможности развития и внедрения ресурсосберегающих технологий в современных условиях // Экономика в промышленности. 2014. № 4. C. 55-59.

51. Портер М. Конкуренция. СПб.; М.; Киев: Издательский дом «Вильямс», 2018. $608 \mathrm{c}$.

52. Постановление Правительства РФ от 21.04.2014 № 366 (ред. от 31.08.2017 № 1064) «Об утверждении государственной программы Российской Федерации “Социально-экономическое развитие Арктической зоны Российской Федерации на период до 2020 года”»// ГАРАНТ: сайт. URL: https://base.garant.ru/70644266/.

53. Постановление Правительства РФ № 41 от 28.01.2016 «Об утверждении Правил предоставления из федерального бюджета субсидий участникам промышленных кластеров на возмещение части затрат при реализации совместных проектов по производству промышленной продукции кластера в целях импортозамещения» // Официальный интернет-портал правовой информации. URL: http://pravo.gov.ru/proxy/ips/?docbody= \&prevDoc $=102445793 \&$ backlink $=1 \& \&$ nd $=102388360$.

54. Проект «Ямал». URL: http://www.gazprom.ru/ projects/yamal/ (дата обращения: 29.03.2019).

55. Промыслов Б. Д., Жученко И. А. Логистические основы управления материальными и денежными потоками (проблемы, поиски, решения). М.: Нефть и газ, 1994. 103 с.

56. Родионов П. Е. Инвестиционный климат в России // Вопросы экономики. 1999. № 12. C. 4-33.

57. Рохчин В. Е. Реализация проектов глубокой переработки отечественных минерально-сырьевых ресурсов и экономика Северо-Запада России // Хабаровск: Регионалистика (электронный научный журнал). 2014. Т. 1, № 1.

58. «Сахалин-2» - первый в России завод по производству сжиженного природного газа // ПАО «Газпром». URL: http://www.gazprom.ru/projects/ chayandinskoye/ (дата обращения: 23.01.2019).

59. Селин В. С., Козьменко С. Ю., Геращенко Л. В. Арктические коммуникации и региональные геополитические приоритеты экономического развития России // Геополитика и безопасность. 2012. № 2 (18). C. 94-102. 
60. Состоялась закладка первого ледокольного судна обеспечения для проекта Новый Порт // Официальный сайт ПАО «Газпром нефть». URL: http://www.gazprom-neft.ru/press-center/news/1109633/ (дата обращения: 02.10.2018).

61. Сценарные условия и прогнозирование долгосрочного развития мегаполиса: монография / под ред. д-ра эконом. наук С. В. Кузнецова и д-ра эконом. наук В. Е. Рохчина. СПб.: ИПРЭ РАН; ГУАП, 2014. 140 с.

62. США и Китай заключили «историческое» соглашение, завершив торговую войну // EurAsia Daily. URL: https://eadaily.com/ru/news/2020/ 01/15/ssha-i-kitay-zaklyuchili-istoricheskoe-soglashenie-zavershiv-torgovuyuvoynu (дата обращения: 20.06.2020).

63. Татаркин А. И., Романова О. А. Промышленная политика: теоретические основы, практика реализации // Региональная экономика: теория и практика. 2012. № 6. С. 19-31.

64. Транскорейский газопровод: похороны или преображение? // Российский совет по международным делам. URL: https://russiancouncil.ru/analyticsand-comments/analytics/transkoreyskiy-gazoprovod-pokhorony-ilipreobrazhenie/ (дата обращения: 19.06.2020).

65. Трансформирующийся глобальный рынок СПГ: как России не упустить окно возможностей? // Энергетический центр Московской школы управления Сколково. URL: https://energy.skolkovo.ru/downloads/ documents/SEneC/News/Russia-on-global-spg-market.pdf (дата обращения: 01.02.2020).

66. Ульченко М. В. Перспективы поставок российского арктического природного газа в страны Азиатско-Тихоокеанского региона // Север и рынок: формирование экономического порядка. 2020. № 1 (67). С. 79-89.

67. Ульченко М. В. Российский арктический сжиженный природный газ: в борьбе за рынки сбыта // Север и рынок: формирование экономического порядка. 2019. № 1 (63). С. 78-88.

68. Федеральный закон «О промышленной политике в Российской Федерации» № 488-Ф3 от 31.12.2014 // ГАРАНТ: сайт. URL: https://base.garant.ru/70833138/.

69. Федеральный закон «Об инвестиционной деятельности в Российской Федерации, осуществляемой в форме капитальных вложений»: принят 25.02.1999 г. № 39-Ф3 // Кодексы и законы РФ. СПб.: ИД «Весь», 2003. C. $335-352$.

70. Филин С. Инвестиционный риск и его составляющие при принятии инвестиционного решения // Инвестиции в России. 2002. № 3. С. 24-33.

71. Чернова Г. В. Практика управления рисками на уровне предприятия. СПб.: Питер, 2000. 176 с.

72. Шмидт К. Д., Лысенко В. Л., Маршалова А. С., Новоселов А. С. Проблемы формирования и развития рынков Сибири: препринт. Новосибирск: ИЭИОПП, 1993. 38 с.

73. Щеголькова А. А., Ульченко М. В. Воспроизводство запасов природного газа в российской Арктике: экономический аспект // Известия СанктПетербургского государственного экономического университета. 2018. № 5 (113). C. 113-120. 
74. Эксперты: США переживают самое крупное сокращение числа буровых установок в истории // TACC. URL: https://tass.ru/ekonomika/8450191 (дата обращения: 15.06.2020).

75. Юданов А. Ю. Конкуренция: теория и практика. М.: ООО «Гном-Пресс», $1998.381 \mathrm{c}$.

76. Южная Корея увеличивает закупки российского СПГ // НЕФТЬ. КАПИТАЛ. URL: https:/oilcapital.ru/news/export/26-09-2019/yuzhnayakoreya-uvelichivaet-zakupki-rossiyskogo-spg (дата обращения: 17.06.2020).

77. Япония: вперед-назад к атомной энергетике // НЕФТЬ. КАПИТАЛ. URL: https://oilcapital.ru/article/general/17-08-2017/yaponiya-vpered-nazad-katomnoy-energetike-172e9bfe-f9f6-4f14-a182-8f8dc3111200 (дата обращения: 21.06.2020).

78. BP Statistical Review of World Energy 2015-2019. URL: https://www.bp.com/ (дата обращения: 20.07.2019).

79. GIIGNL. International group of liquefied natural gas importers. The LNG industry in 2018. URL: https://giignl.org/sites/default/files/PUBLIC_AREA/ Publications/giignl_annual_report_2019-compressed.pdf (дата обращения: 12.07.2019).

80. Jason F. Patrick, Maxwell J. Robb, Nancy R. Sottos, Jeffrey S. Moore \& Scott R. White. Polymers with autonomous life-cycle control // Nature. 540. P. 363 370 (15 December 2016).

81. Rutterford J. Introduction to stock exchange investment. 2nd ed. Basingstoke: Macmillan, 1993. 445 p.

82. Total: официальный сайт. Россия: дан старт строительству гигантского проекта «Арктик СПГ 2». URL: https://ru.total.com/ru/rossiya-dan-startstroitelstvu-gigantskogo-proekta-arktik-spg-2 (дата обращения: 18.06.2020).

83. Turow L. The Future of Capitalism. N. Y., 1996. 
Научное издание

Коллектив авторов

ОРГАНИЗАЦИЯ ИНФРАСТРУКТУРНОЙ ПОДДЕРЖКИ АРКТИЧЕСКОЙ НЕФТЕГАЗОВОЙ ОТРАСЛИ

Редактор Е. Н. Еремеева

Технический редактор В. Ю. Жиганов

Подписано в печать 07.12.2020. Формат бумаги 70×108 1/16.

Усл. печ. л. 14. Заказ № 5. Тираж 500 экз.

Федеральное государственное бюджетное учреждение науки Федеральный исследовательский центр «Кольский научный центр РАН»

184209, г. Апатиты, Мурманская обл., ул. Ферсмана,14

Тел.: (81555) 7-53-50; 79-5-95, фракс: (81555) 76425

E-mail: ksc@ksc.ru.www.ksc.ru, naukaprint.ru 
ИНСТИТУТ ЭКОНОМИЧЕСКИХ ПРОБЛЕМ ИМ. Г.П. ЛУЗИНА -

ОБОСОБЛЕННОЕ ПОДРАЗДЕЛЕНИЕ ФГБУН

ФЕДЕРАЛЬНОГО ИССЛЕДОВАТЕЛЬСКОГО ЦЕНТРА

«КОЛЬСКИЙ НАУЧНЫЙ ЦЕНТР РОССИЙСКОЙ АКАДЕМИИ НАУК»

РОССИЯ, 184209, Мурманская область, г.Апатиты, ул.Ферсмана, 24а
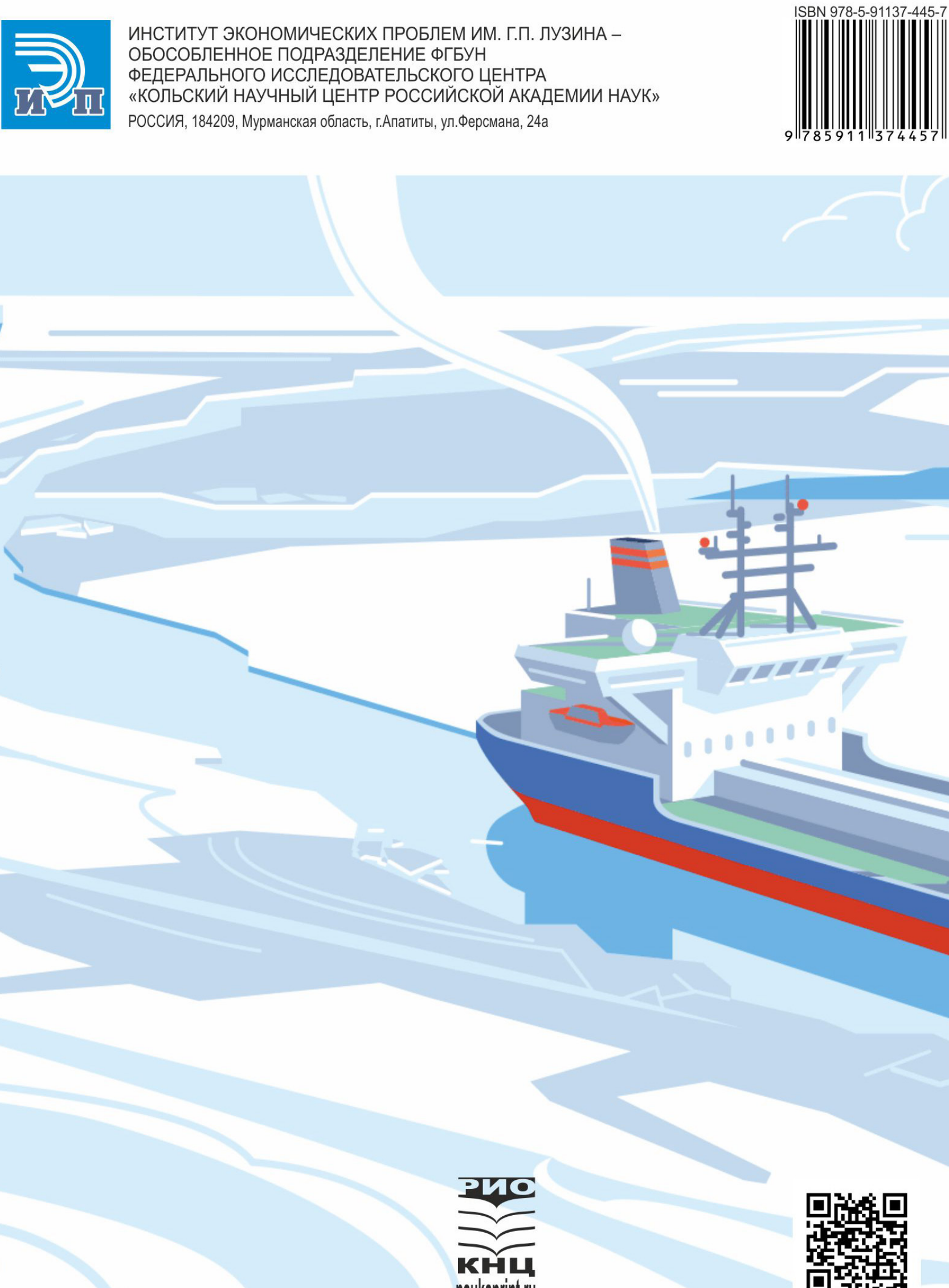

naukapinintilu

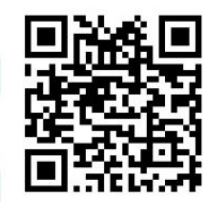

